\title{
Votes, Money and Violence
}

Political Parties and Elections in Sub-Saharan Africa

\author{
Edited by \\ Matthias Basedau, Gero Erdmann and Andreas Mehler
}

NORDISKA AFRIKAINSTITUTET, SWEDEN

UNIVERSITY OF KWAZULU-NATAL PRESS, SOUTH AFRICA 


\section{Indexing terms:}

Elections

Electoral systems

Political parties

Democracy

Political systems

Political pluralism

Aultipartyism

Africa south of the Sahara

\footnotetext{
All rights reserved. No part of this publication may be reproduced or transmitted in

any form or by any means, electronic, mechanical, including photocopying, recording or any information storage and retrieval system, without prior permission in writing from the Nordic Africa Institute and University of KwaZulu-Natal Press.
}

Language checking: Elaine Almén

Index: Margaret Binns

Cover Photo: Jørn Stjerneklar/Bildbyrå PHOENIX

The portrait of Joaquim Chissano on a young womans clothes. Ulongwe, Mozambique.

ISBN 978-91-7106-579-7

(C) The authors and Nordiska Afrikainstitutet 2007

P.O. Box 1703, SE-751 47 Uppsala, Sweden

Printed in Sweden by Elanders Gotab AB 2007

Published in Africa by University of KwaZulu-Natal Press

Private Bag X01, Scottsville, 3209, South Africa

www.ukznpress.co.za

ISBN 978-1-86914-119-6 


\section{Contents}

Acknowledgements ……………………………………………...

Introduction: Research on Electoral Systems, Parties and Party Systems in Africa

Gero Erdmann, Matthias Basedau and Andreas Mebler 7

Political Parties, Elections and Patronage: Random Thoughts on Neo-Patrimonialism and African Democratization

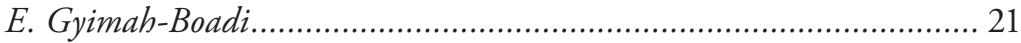

Party Research: Western European Bias and the 'African Labyrinth' Gero Erdmann

Political Parties in Africa: Different, Functional and Dynamic?

Reflections on Gero Erdmann's 'Party Research:

Western European Bias and the "African Labyrinth"”

Peter Burnell.

Political Parties in Africa and the Representation of Social Groups

Vicky Randall

Do Party Systems Matter for Democracy?

A Comparative Study of 28 Sub-Saharan Countries

Matthias Basedau.

Paths of Electoral Reform in Africa

Christof Hartmann

Electoral Systems, Party Systems and Ethnicity in Africa Matthijs Bogaards.

Political Parties and Violence in Africa:

Systematic Reflections against Empirical Background 
Andreas Mehler

194

Insights into Electoral Violence in Africa

Liisa Laakso

224

Banknotes and Symbolic Capital:

Ghana's Elections Under the Fourth Republic

Paul Nugent.

253

Conclusion: The Research Agenda Ahead

Gero Erdmann, Matthias Basedau and Andreas Mehler. 276

Contributors

293

Index

294 


\section{Acknowledgments}

We are very grateful to the Fritz Thyssen Foundation (Cologne) and Heinrich Böll Foundation (Berlin) for their generous support of the Thematic Conference of the Africa-Europe Group for Interdisciplinary Studies (AEGIS) 'How People Elect Their Leaders. Parties, Party Systems and Elections in Africa South of the Sahara' 22-23 May 2003, Hamburg. Both foundations enabled us to invite numerous contributors and discussants from both Europe and Africa.

We would also like to thank the contributors to this volume not only for the quality of their papers but also for their patience during what was a rather extended production period.

The conference was organised by the Institute of African Affairs of the German Institute of Global and Area Studies (GIGA, formerly German Overseas Institute); most of the contributions to this volume are based on early versions of the papers presented at the conference.

The editors

Hamburg, February 2006 



\title{
Introduction \\ Research on Electoral Systems, Parties and Party Systems in Africa
}

\author{
Gero Erdmann, Matthias Basedau and Andreas Mehler
}

After the sweeping (re-)introduction of multi-party systems in Africa during the early 1990s, 'fourth elections' are now due in some of Africa's new democracies and hybrid regimes. While the circumstances of the 'second elections' in the late 1990s were viewed with increasing scepticism (Bratton and Posner 1999), the fact that third and fourth elections are to take place suggests the need for a second look at the role of elections as a basic instrument for regulating political competition in Africa. The scepticism, which was based on comparatively few cases, has probably been premature and even misleading. The negative trend of the second elections has not been sustained, rather a slight improvement can be noted (Lindberg 2004a: 75-6). Multi-party elections have clearly become a regular institution in Africa, even though there are still many doubts about the meaning and the quality of these elections or - to use Staffan Lindberg's (2004b) phrase in his book - about the 'power of elections'. Lindberg's data indicates that contrary to general belief the quality of elections has in fact improved so that he can optimistically conclude: 'A series of elections will, more often than not, contribute to democratisation' (Lindberg 2004a: 86).

A similar thing can also be said of the key actors in these elections, namely the political parties. Although interviews, discussions, election reports and observation of party conduct during election campaigns seem to lend support to the belief that political parties are not held in high regard by the African public, opinion poll data seems to suggest otherwise. The ruling parties, especially in dominant or predominant party systems such as Namibia, Zambia, and Botswana have received relatively good assessments - 48 per cent of people interviewed in 15 African countries trust their political parties. Interestingly, it is the opposition parties that are the least trusted of public institutions (Afrobarometer 2004: 34-5). Overall, however, political parties belong to the least trusted institutions.

The lack of trust in opposition parties sheds a rather doubtful light on the role of political parties as regards their importance for the functioning 
and consolidation of democracy. It also seems to justify old reservations about the appropriateness of politics in Africa's multiethnic societies. One explanation for this public scepticism of the value of opposition parties is that they are not really visible in the periods between elections. We have learned from focus group interviews in Ghana and Zambia during 2003 that 'You see political parties only before the elections. Afterwards they disappear again, completely'.

Before passing judgement on Africa's political landscape it is healthy to take a sober look at what is happening closer to home. A recent Eurobarometer (2004) survey indicates that only 16 per cent of the people interviewed in Europe trust political parties. The situation in Africa is not, therefore, an unusual one. Perhaps, there is no major reason to feel concerned about it. However, we do not know very much about the political meaning of different levels of trust in different political contexts, that is, in new democracies or hybrid regimes versus consolidated democracies.

The collection of articles that make up this volume deals with these two core institutions of democracy: elections and political parties. Seymor Martin Lipset's (2000) dictum on the "indispensability of political parties" remains unchallenged. Even African scholars who are critical to what is 'western' accept it. ${ }^{1}$ Even beyond liberal democratic ideas, these two aspects of a democracy are important as a focus of research because in Africa there are many hybrid and even authoritarian regimes that attempt to obtain legitimacy via multi-party elections. Surprisingly, however, almost 15 years after the 'wind from the East that is shaking the coconut trees' of Africa (Omar Bongo, Africa, 9 April 1990), there is still little systematic empirical research in this area. While elections have received a fair degree of scholarly attention, this is not true as regards African political parties or party systems. Even the election research is limited, being concentrated on case studies and more often than not linked to the 'technical' issues of election observation. Systematic comparative research about the effects of elections and different election systems on, for example, the quality of the political regime (democratic, hybrid), the development of party systems, civil liberties, or political party organisation is largely missing. Andrew Reynolds' (1999) work is of course an exception, although in some respects it is typical. He (1999: 267) concludes his comparative analysis by stating that proportional representation (PR) electoral systems outperform their plurality-majority alternatives in many performance criteria, especially in-

1. See for example Salih 2005. 
clusion and chances for new and smaller parties. These results are based on only five cases, two of which are atypical, and therefore any generalisations are dubious. The two PR cases, Namibia and South Africa, are not wellsuited to study the potential perils of the PR electoral system: problems for government formation and policy implementation as a result of party system fragmentation - the classic effect of PR systems - have not materialized because historical and ethnic cleavages favoured the emergence of dominant parties in both countries. If other countries with PR and plurality systems such as Botswana, Liberia, and Sierra Leone had been added to the study, there would have been considerably different results. Thus, we still do not know how appropriate particular electoral systems (in many instances inherited from colonial powers) are for the multiethnic context of African polities.

The situation is not really any better for research on political parties or on political party systems. Although political parties have a long history on the continent, a number of them date back to the early 20th century - the first even to 1860 (Liberia) - sound empirical research on the development of political parties is surprisingly scant. While almost 150 political parties were established during the first phase of decolonisation up to the mid1960s, we knew very little about the way these parties operated. The problem then was that party research was based on the West European concept of the 'mass party' which was assumed to have been applicable to Africa but as we now know fails to capture essential differences in Africa (Erdmann 2002). While Immanuel Wallerstein (1966) was the first who articulated his discomfort about the 'mass' character of the political parties after independence, based on his empirical research in Tanzania, Henry Bienen (1967: 216) demolished the pretensions of political parties in Africa at that time: "No matter what roles parties have been assigned, almost everywhere in tropical Africa ... they performed few". It was again Bienen who also pointed out fundamental scholarly weaknesses of party research in Africa: "a mutually reinforcing pattern of lack of empirical work, poor deductions, and a failure to perceive the need for different kinds of empirical research" (Bienen 1971: 200). When this failure became apparent, empirical party research had already been precluded in many African countries because of the widespread turn to authoritarian rule and the evolution of one-party systems which became so common on that continent.

Despite the proliferation of several hundred new political parties in the early 1990s, it is only very recently that a number of works on parties have been published. Amongst these, research on political party systems is more 
numerous than on issues of political parties as organisations. However, the publications on party systems often suffer the shortcoming that they treat, for example, the African party systems as conceptually isolated from the mainstream of political party research. They use their own ad hoc typologies without even discussing established concepts. ${ }^{1}$ Notable exceptions are Bogaards (2003) and Cranenburg (1996) who relate their explorations to established party system typologies and also Kuenzi and Lambright (2001; 2005) who apply established concepts of political science party research. There is, of course, a problem with the African parties and especially party systems because they tend not to be institutionalised yet, but inchoate. Sartori (1976), however, provides a solution for this problem of differentiating between 'fluid' and 'structured' polities. ${ }^{2}$ In any case, it is an issue not only related to party politics in Africa but for many young democracies of the so called Third Wave, particularly in less developed countries (Mainwaring 1998; Bendel and Grotz 2001). Other scholars analyse African party systems without even attempting to discriminate among more than 40 different cases, but provide an African 'average type' of party system (high volatility and low fragmentation) based on comparative quantitative data (Mozaffar and Scarritt 2003; 2005). Without a differentiated typology of party systems in Africa, as an auxiliary analytical tool, we have problems to analyse and discuss the effects of different features of party systems in relation to other phenomena such as regime stability, governability, or the consolidation of democracy.

It is noteworthy that studies of the relation between political parties and party systems with respect to the process of democratisation and its consolidation have only just started to get underway with the publication of a first explorative work by Vicky Randall and Lars Svåsand (2002), although some previous articles have addressed this question in a rather tentative way as well. There is, however, no concluding result. Some researchers point out serious problems for consolidation (van de Walle 2003: 316; Randall and Svåsand 2002), while others see the parties and emerging party systems as conducive to consolidation (Mozaffar et al. 2003: 389); yet others warn against passing judgement too quickly (Randall and Svåsand 2002). The reasons for these conflicting views are manifold. One is that most of the African party systems are still in an emerging state that makes judge-

1. See for example Sandbrook 1996; see also Walle and Butler 1999; Walle 2003; Rakner and Svåsand 2004.

2. See also Mainwaring and Scully 1995; Bendel 1996; Mainwaring 1999. 
ment difficult. Other reasons are methodological. One is related to the issue mentioned above, the lack of criteria for systematic discussion of the various qualities of different party systems in relation to the consolidation of democracy - some types of systems are more prone towards consolidation than others. Another reason is linked to the question of reference: is the type of party or the type of party system related to consolidation? Van de Walle as well as Randall and Svåsand focus on party weaknesses while Mozaffar et al. address a rather abstract 'average party' or a 'dominant multiethnic pattern of ethnopolitical cleavages ... and the resulting party systems' (Mozaffar et al. 2003: 389). In other words, a party system based on multiethnic parties. They refrain from identifying particular types of party systems. The conflicting result can probably be explained in part from their different starting points.

As indicated above, there is no clear result of what sort of party systems emerged in Africa. However, one trend seems to be clear. Early observations about highly fragmented party systems proved to be wrong (Schmidt 1996: 53-54; Widner 1997: 66; Van de Walle 2003: 302). The argument was based on the prevalence of ethnic fragmentation and ethnic politics in Africa. The point was made by equating ethnic groups with political parties. Contrary to Widner's (1997: 66) early 'extreme fragmentation' a different perception of one party domination is gaining ground (Erdmann 1999: 387; van de Walle 2003; Bogaards 2003: 192): the predominance of 'dominant party' or 'one-party dominant systems'. This short overview of the party system related works brings methodological issues to the forefront.

As regards the research on political parties as organisations the situation is even worse. While research on political party systems can successfully be done from Europe, the USA or African universities, proper party research requires field work in Africa, and it should not be confined to the party headquarters in the capital. Little systematic work has been undertaken on the organisation of the different parties in Africa - hence the sweeping generalisations derived from rather cursory observations (obtained in the course of other related research) characterise our knowledge about the several hundred parties in 48 countries of Africa south of the Sahara.

For example, we do not know exactly with what kind of parties we are dealing with in Africa. There is no acknowledged political party typology that would allow us to give these various parties a 'name' and to categorise them. Are we finally confronted with 'mass parties', 'catch-all', 'cartel', 'cadre parties' or 'machines'? All these concepts are derived from party re- 
search in Europe or the USA. Can we apply them to Africa? If yes, are these really useful concepts for the African context? Or perhaps it might be more reasonable to look for concepts of an earlier stage of party development in 19th century Europe, such as Max Weber's 'Honoratiorenpartei' (parties of dignitaries) or Maurice Duverger's (1954) classical concept of the 'elite party'?

It has become common to say that African parties are different from the parties we know from contemporary or even historical industrialised countries. The reasoning is as simple as it is plausible: the historical and societal context is different. But does the suggested 'distinctiveness' apply to all parties in Africa in the same way? And moreover, what is the 'otherness' of political parties in Africa - at least, of some of them? All these questions are not completely unanswered. There are some points in common that provide for a description of political parties: personalism, patronage, clientelism, elite and ethnic based, to name a few. But we lack systematic research on how these features relate to each other and how they operate. We also lack an appropriate typology for the description and the analysis of political parties in Africa. Such a typology is, of course, not an end in itself, but a necessary analytical tool for (a) the purpose of differentiation and (b) comparative purposes (e.g. either to compare different parties in their effects on the party system and/or in relation to the formation of governments, the consolidation of democracy etc. or even with parties and their effects in other world regions). The endeavours in the 1960s to create a specific African or Third World typology are not very helpful, as most of them failed to leave any tracks in the literature (Erdmann 2002: 260-265). ${ }^{1}$

There are, of course, a number of works which provide useful information about political parties within their respective political systems in Africa. Mohamed Salih's (2003) collection of case studies is a commendable attempt to provide much needed information about some African countries. The effort unfortunately lacks a coherent approach; the eclecticism of the studies it contains provides some useful insights into single cases but works against any systematic comparison. The same applies to the works compiled in an issue of Democratization edited by Vicky Randall and Lars Svåsand (2002). Hence, we can only conclude that there is a vast field open for research. This volume starts to tackle the theoretical and methodological issues that are open.

1. See for example Hodgkin 1961; Morgenthau 1964; Coleman and Rosberg 1964; LaPalombara and Weiner 1966. 
These general observations of the research landscape provided the background for the AEGIS Thematic Conference 'How people elect their leaders. Parties, Party Systems and Elections in Africa South of the Sahara' organised by the Institute of African Affairs (Hamburg). The idea was not to provide a comprehensive overview over the wide field of party research related to Africa (an impossible task for a conference because of the sheer number of neglected research issues) but rather was an attempt to bring together a number of scholars with an Africanist (political scientist, historian and anthropological) as well as a general political science background who might be able to cast some light on at least a few of the issues involved. Hence, the articles in this volume aim at initiating a more systematic approach to the study of political parties, party systems, and the meaning of elections in Africa. In this regard, almost all of the contributions are explorative in character in that they attempt to set out future lines of research rather than provide substantial knowledge.

This book is not a complete replica of the conference in that not all of the presentations are included here and some are later additions. Christof Hartmann, Matthijs Bogaards, and Matthias Basedau turned their comments during the conference into articles. Andreas Mehler's contribution is a revised and translated version of an earlier working paper.

\section{Political party research}

E. Gyimah-Boadi's paper developed from his very personal keynote address, Political parties, elections and patronage: Random thoughts on neo-Patrimonialism and African democratization, provides a vivid introduction to the chequered history of elections and political parties and their ups and downs in Ghana - a history in which many of the diverse political developments in Africa concur. He sets out to provide a general overview of the seemingly countless problems which we encounter with African political parties. One of his major concerns is the question of how the heritage of neopatrimonialism, which is seen as a hindrance to democratic, social and economic development, can be overcome through competitive multi-party elections. Despite a clear advantage in the leverage of patronage, it is obvious that neopatrimonial rulers can be dislodged from power by using electoral powers. But, the crucial problem is how to prevent the successor governments from returning to, or continuing with, systematic neopatrimonial politics. 
As mentioned above, for more than a quarter of a century there was hardly any substantial research on political parties in Africa. This poor state of political party research is taken up in Gero Erdmann's contribution, The Western European Bias and the 'Africa Labyrinth', in which he explores the possibility, or rather the necessity, to bring African political party research back into the mainstream of political science party research. Erdmann's contention is that the long held assumption of Africanists that political parties in Africa are basically different from parties elsewhere in the world has contributed to a lack of systematic research and even led research on political parties into a not very productive eclecticism and isolation. This isolation needs to be overcome by applying established research methods and concepts of party research. Applying these concepts and methods requires, however, some modifications of the established research tools that are largely shaped by a very narrow West European experience and research agenda.

The wide dimension of informal politics needs, for example, to be included in further research on political parties. By conceptualising informal politics, research on African political parties can contribute to the enrichment of often somewhat culturally sterile political science research on political parties. A tentative reorientation of political party research has already started to get underway in the last couple of years, especially since the return to democracy in many areas outside Europe.

Erdmann's propositions are critically discussed in Peter Burnell's comment, Political Parties in Africa: Different, Functional and Dynamic? In support of Erdmann's previous proposition he highlights some of his points but enlarges the research agenda by asking additional questions, raising new issues, and exploring the wider comparative implications - in short, pointing out numerous lines of pertinent research issues.

\section{Parties, social representation and democracy}

Directly related to the new orientation of political party research is the fundamental question about one of the core functions of political parties, namely representation. In other words, which part of the population, which social groups, and which interests are actually represented by political parties? Parties are supposed to express the demands of these groups. Representation is, of course, not only crucial for political parties but vital for democracy in general. This is taken up in Vicky Randall's Political Parties in Africa and the Representation of Social Groups. After discussing the 
various forms of representation along the lines of seminal work of Hannah Pitkin - descriptive ('standing for') vs. responsive ('acting for') - and their relevance for political parties, Randall surveys existing research on representation in relation to ethnic groups, civil society, and women. The scant literature on this subject means that she can only draw the tentative conclusion that political parties offer some representation for ethnic groups and women, more problematic still is the representation of civil society for which it is difficult to find evidence.

While some work has been done on the relationship between political parties and the consolidation of democracy in Africa, ${ }^{1}$ in his article, Do Party Systems Matter for Democracy? A Comparative Study of 28 SubSaharan Countries, Matthias Basedau examines the relationship between party systems and democracy. More precisely, he asks whether there is a systematic relationship between types or rather characteristics of party systems and a democratic or non-democratic regime performance. Theoretically, this relationship is simply assumed but rarely analysed, and certainly not for Africa. In his analysis, Basedau treats democracy as a dependent variable, which is something that transition research and the theory of democracy presume. Using a functionalist approach he applies the descriptive categories of fragmentation, a modified version of polarisation and institutionalisation, which are well established concepts for political party system research. His medium $\mathrm{N}$ analysis suggests tentatively that it is the polarisation of the party system that is the distinguishing explanans for a democratic or non-democratic regime.

\section{Electoral systems}

Matthijs Bogaards and Christof Hartmann examine the issue of elections, or more precisely that of electoral systems. Bogaards' investigation Electoral Systems, Party Systems, and Ethnic Conflict Management addresses one of the most problematic issues that confront democracy in Africa: the belief that ethnic diversity could produce a myriad of political parties, increase ethnic conflict, and destabilise entire states. It is clear that the choice of a particular electoral system - classically simplified to the choice between a proportional or plurality (first-past-the-post) procedure - shapes the electoral competition and the political management of conflict. In the case of many African countries, the system influences political articulation and

1. See the special edition of Democratization 9: 3, 2002 edited by Vicky Randall and Lars Svåsand. 
organisation of ethnicity as one cleavage for party formation. Research on electoral systems, however, has pointed out that the effects of the various electoral systems are very much dependent on societal context (Nohlen 1996; 2000). In line with this, Bogaard maintains that the old controversy about proportional or plurality elections loses most of its relevance because of the territorial concentration of ethnic groups. Bogaard's chapter can also be read as a contribution from an institutionalist perspective to the debate about the management of ethnic conflict.

In fact, as we learn from Hartmann's Politics of Electoral Reform in Africa electoral reform is a thorny business in Africa. Electoral systems are crucial for shaping political competition and conflict and through that relate to the fate of the democratic regime. Therefore they are hotly disputed in some African countries. The conventional wisdom maintains that the electoral systems - along the fault line of proportional and plurality systems - have been inherited from the former colonial rulers. However, this is far from true. As Hartmann points out electoral systems in Africa are much more varied than they are believed to be; and they have been changed since decolonisation. So he is interested in the varieties of electoral systems in Africa and in the question of what makes some countries reform their electoral systems and others not. Hartmann surveys the reforms of electoral systems as a dependent variable and seeks to explain why such reforms were envisaged and implemented.

\section{Electoral violence}

Closely related to the institutional management of conflict are Andreas Mehler's and Lisa Laakso's treatments of the occurrence of violence in the context of political party and electoral competition. Although violence during African electoral campaigns is a very frequent phenomenon, the focus of research has more or less been on the link between electoral systems and conflict management (Sisk and Reynolds 1998) rather than on the relationship between elections, violence and political parties - something which is not restricted to the African context. Hence, there is hardly a theoretical or conceptual framework available to address this issue. In their respective contributions, Political Parties and Violence in Africa. Systematic Reflections against Empirical Evidence and Insights into Electoral Violence in Africa, Mehler and Laakso attempt to break new ground in this field. In his overview, Mehler shows that the relation of violence to political parties depends on a variety of causes and contexts and that its use is not restricted to 
either ruling or opposition parties. Laakso's contribution concentrates on electoral violence and its specific circumstances in Kenya, Tanzania, and Zimbabwe, none of which is regarded as a democracy, albeit these countries maintain very competitive multi-party systems. It turns out that electoral violence does not just occur, but is usually strategically instigated and even very well organised by party officials using socio-economic grievances for violent political mobilisation.

\section{Elections and wealth}

Paul Nugent's article is a study of informal politics during election periods, that is, about the role of money and how universal institutions such as elections are adapted to a local context. Although it is a case study, it is paradigmatic in an important sense. Accusations of vote buying flare up in almost all African elections; patronage, the misuse of public funds and vehicles are other issues. Despite the frequency of these accusations, nobody really knows if money can buy votes. Even poor rural people are not completely ignorant. They frequently turn up at election rallies of different parties; and often, regardless of who is offering the items, they take the t-shirts or the maize bags as they carry the membership cards of several parties - for there might be circumstances where a specific card can be useful. In his Banknotes and Symbolic Capital: Ghana's Elections under the Forth Republic, Nugent sheds some new light on the murky 'vote buying trade'. He asserts that if a ballot is secret, money cannot be directly converted into votes unless it is first transfigured into a 'moral authority' which is linked to other aspects of leadership. In the absence of this, money will become profane and identified as what it is: corruption and vote buying. This might turn it into precisely the opposite: a competitive liability. Hence, he reminds us that the meaning of money can be very ambiguous in an electoral contest. The concluding chapter takes up the questions of future research. 


\section{References}

Afrobarometer (2004), Afrobarometer Round 2: Compendium of Comparative Results from a 15-Country Survey. Working Paper No. 34.

Bendel, P. (1996), Parteiensysteme in Zentralamerika. Opladen: Leske and Budrich.

Bendel, P. and F. Grotz (2001), 'Parteiensysteme und Demokratisierung. Junge Demokratien in Afrika, Asien und Lateinamerika im Vergleich', Nord-Süd aktuell, 1, pp. 70-80.

Bienen, H. (1967), 'The Ruling Party in the African One-party State: TANU in Tanzania', Journal of Commonwealth Political Studies 5, pp. 214-230.

Bienen, H. (1971), 'Political Parties and Political Machines in Africa', in Lofchie, M. (ed.) The State of the Nations: Constraints on Development in Independent Africa. Berkeley: University of California Press, pp.195-214.

Bogaards, M. (2004), 'Counting Parties and Identifying (Dominant) Party Systems in Africa', European Journal of Political Research 43: pp. 173-197.

Bratton, M. and D.N. Posner (1999), 'A First Look at Second Elections in Africa, with Illustrations from Zambia', in Joseph, R. (ed.) State, Conflict, and Democracy in Africa. Boulder: Lynne Rienner, pp. 377-408.

Coleman, J.S. and C.G. Rosberg (eds) (1964), Political Parties and National Integration in Tropical Africa. Berkeley: University of California Press.

Cranenburg, O. v. (1996), 'Tanzania's 1995 multi-party elections. The emerging party system', Party Politics 2: 4, pp. 535-547.

Duverger, M. (1954), Political Parties: Their Organization and Activity in the Modern State. New York: Wiley.

Erdmann, G. (1999), 'Parteien in Africa. Versuch eines Neuanfangs in der Parteienforschung', Afrika Spectrum 34: 3, pp. 375-393.

Erdmann, G. (2002), 'Zur Typologie politischer Parteien in Afrika', Afrika Spectrum 37: 3, pp. 259-285.

Eurobarometer (2004), 'Standard Eurobarometer 61'. http://europa.eu.int/comm/ public_opinion/archives/eb/eb61/eb61_en.pdf

Hodgkin, T. (1961), African Political Parties. London: Penguin Books.

Kuenzi, M. and G. Lambright (2001), 'Party System Institutionalisation in 30 African Countries', Party Politics 7: 4, pp. 437-468.

Kuenzi, M. and G. Lambright (2005), 'Party Systems and Democratic Consolidation in Africa's Electoral Regimes', in Party Politics 11: 4, pp. 423-446.

LaPalombara, J. and M. Weiner (1966), 'The Origin and Development of Political Parties', in LaPalombara, J. and M. Weiner (eds) Political Parties and Political Development. Princeton: Princeton University Press, pp. 3-42.

Lindberg, S. (2004a), 'The Democratic Qualities of Competitive Elections: Participation, Competition and Legitimacy in Africa', Journal of Commonwealth and Comparative Politics 42: 1, pp. 61-105.

Lindberg, S. (2004b), The Power of Elections. Democratic Participation, Competition, and Legitimacy in Africa. University of Lund: Lund Political Studies 134. 
Lipset, S.M. (2000), 'The Indispensability of Political Parties', Journal of Democracy 11: 1, pp. 48-55.

Mainwaring, S. (1998), 'Party Systems in the Third Wave', Journal of Democracy 9: 3, pp. 67-81.

Mainwaring, S. (1999), Rethinking Party Systems in the Third Wave of Democratization. The Case of Brasil. Stanford: Stanford University Press.

Mainwaring, S. and T.R. Scully (1995), 'Introduction: Party Systems in Latin America', in Mainwaring, S. and T.R. Scully (eds) Building Democratic Institutions. Party Systems in Latin America. Stanford: Stanford University Press, pp.1-36.

Morgenthau, R.S. (1964), Political Parties in French-Speaking West Africa. Oxford: Clarendon Press.

Mozaffar, S et al. (2003), 'Electoral Institutions, Ethnopolitical Cleavages, and Party Systems in Africa's Emerging Democracies', American Political Science Review 97: 3, pp. 379-390.

Nohlen, D. (1996), Elections and Electoral Systems. New Delhi: Macmillan.

Nohlen, D. (2000), Wahlrecht und Parteiensystem, Opladen: Leske+Budrich.

Randall, V. and L. Svåsand, (2002), 'Political Parties and Democratic Consolidation in Africa', Democratization 9: 3, pp. 30-52.

Rakner, L. and L. Svåsand, (2004), 'From Dominant to Competitive Party System. The Zambian Experience 1991-2001’, Party Politics 10: 1, pp. 49-68.

Reynolds, A. (1999), Electoral Systems and Democratization in Southern Africa. New York: Oxford University Press.

Sisk, T.D. and A. Reynolds (eds) (1998), Elections and Conflict Management in Africa. Washington: United States Institute of Peace Press.

Salih, M.M.E. (ed.) (2003), African Political Parties. London: Pluto Press.

Salih, M.M.E. (2005), Globalized Party-Based Democracy and Africa: The Influence of Global Party-Based Democracy Networks. CSGR Working Paper No. 173/05, August. Warwick: Centre for the Study of Globalization and Regionalization.

Sandbrook, R. (1996), 'Transitions without Consolidation. Democratization in Six African Cases', Third World Quarterly 17: 1, pp. 69-87.

Sartori, G. (1976), Parties and Party Systems. A Framework for Analysis. Cambridge: Cambridge University Press.

Schmidt, S. (1996), 'Zur Rolle der politischen Parteien in afrikanischen Demokratisierungsprozessen', Konrad-Adenauer-Stiftung Auslandsinformationen 6, pp. 53-54.

Van de Walle, N. (2003), 'Presidentialism and Clientelism in Africa's Emerging Party Systems', Journal of Modern African Studies 41: 2, pp. 297-321.

Van de Walle, N. and Smiddy Buttler, K. (1999), 'Political Parties and Party Systems in Africa's Illiberal Democracies', Cambridge Review of International Affairs Vol. 8, No.1, pp. 19-21.

Wallerstein, I. (1966), 'The Decline of the Party in Single-Party Africa', in LaPalombara, J. and M. Weiner (eds) Political Parties and Political Development. Princeton: Princeton University Press, pp. 201-214. 
Weber, M. (1980), Wirtschaft und Gesellschaft. Grundriss der verstehenden Soziologie. Tübingen: Mohr.

Widner, J.A. (1997), 'Political Parties and Civil Societies in Sub-Saharan Africa', in Ottaway, M. (ed.) Democracy in Africa. The Hard Road Ahead. Boulder: Lynne Rienner, pp. 65-82. 


\title{
Political Parties, Elections and Patronage \\ Random Thoughts on Neo-Patrimonialism and African Democratization
}

\author{
E. Gyimah-Boadi
}

\section{Introduction and important caveats}

I have been a lifetime student of politics. But growing up in a country like Ghana means that I have only a dim awareness of certain key political institutions and processes. Among them is the phenomenon of political parties. I only remember hushed conversations at home (in the village) about the United Party (UP) and the Convention People's Party (CPP) among my parents and their close circle of friends, and among my middle class relatives when I was taken to visit them in the city. I knew at that time - even as a young boy - that family members who disliked the ruling CPP did not dare to reveal this even to close relatives and friends who could be CPP; and that you got in trouble if you showed any affection for the opposition United Party. And in elementary school in the late 1950s and 1960s, there was more talk about the figure of Kwame Nkrumah than his party. Then, with the overthrow of Nkrumah in February 1966, parties were banned.

When parties re-entered the political landscape in 1969, I was in secondary school and was beginning to develop a fuller awareness of the world of politics. With the lifting of the ban on party politics, several parties were promptly formed. The Progress Party of Kofi Busia (said to be a reincarnation of the old United Party) and the National Alliance of Liberals of Komla Gbedema (said to be a Nkrumahist Party) were the most prominent parties among about six. However, this flourishing of multi-party activity in the Ghanaian political landscape proved short-lived. In January 1972 when another military coup toppled the Busia and Progress Party Government, political parties were again banned.

The years from 1972 to 1979 could well be described as the anti-political party period in Ghanaian politics. The military regimes of the period (the National Redemption Council (NRC) and Supreme Military Council (SMC) under General Acheampong embarked on a process of what Donald 
Rothchild described aptly as 'purposive depoliticization' which included conscious efforts to denigrate political parties and party systems. They even sought to establish a formal no-party system called Union Government.

Political parties did emerge again in 1979. I was out of the country doing graduate work in the United States, but I understand that the parties divided broadly along the old UP and CPP lines. At any rate, this return to party politics also proved short-lived. Parties were banned yet again after the second coup of Flight Lieutenant J.J. Rawlings on 31 December 1981.

Parties were to stay proscribed from 1982 until 1992 when Ghana embarked on yet another experiment in returning to civilian democratic rule. Happily, this experiment and the multi-party politics that comes with it have lasted for more than ten years.

The above semi-autobiographical sketch underlines the fact that political parties have been officially allowed in Ghana for less than half of its life as an independent country. You can therefore understand why someone like me, with a professional interest in the study of politics, will only have a dim acquaintance with the phenomena of political parties. You can also understand why only few among my generation of Ghanaian social scientists have anything but a shallow understanding and appreciation of how political parties work. And you can also understand why political parties remain some of the most underdeveloped structures in Ghanaian political life today.

I know a little more about elections than political parties in Ghana, even though elections have also been scarce in my own experience. My experience growing up included ritualistic elections in the 1960s - such as the 1964 referendum to make Ghana a one-party state and the 1965 parliamentary elections, held in the context of the de facto one-party state and in which President Nkrumah unilaterally awarded parliamentary seats to ten women in an inspired move to improve the gender balance in the House.

I did have a direct and pleasant encounter with multi-party elections in 1969 when I was asked by an independent candidate for the parliamentary seat in my constituency, faced with the prospect of not meeting the deadline for filing his candidacy, to draw the symbol that would appear beside his name on the ballot paper. He chose the kerosene lamp as his symbol. My fee for this assignment as freelance graphic artist was a princely twenty cedis (about \$10). That, incidentally, was also the first time (at about the age of 15) I saw a competitive election.

I became passionately involved in elections in 1977 when I was a student at the University of Ghana. I became preoccupied with the referen- 
dum of that year - canvassing for a 'No' vote against the proposition put forward by the military regime that Ghana should be governed under a no-party system of government called Union Government, in which power would be shared equally between the military, the police and the civilian population.

Being away from Ghana in 1979, I missed the general elections of that year. But I have been told they were highly competitive and 'free and fair'. However, that proved to be the last general election in Ghana until 1992 - because Jerry Rawlings and the quasi-military and revolutionary Provisional National Defence Council (PNDC) would not entertain any talk of early elections in Ghana.

By the time I returned to Ghana in 1986, elections were generally regarded as a non-issue in the nation's politics. The PNDC was busy propagating a new doctrine of 'new' and 'real' democracy that did not include political parties or elections. When elections were conducted in 1988, they were done on a non-party basis and for local government (District Assemblies). All the same, I was glad to get the chance to vote, even though most of my peers boycotted the elections.

Thus, it is only since 1992 that I have had direct encounters with elections in Ghana. In 1996 and 2000, I was part of a team that managed the civil society independent election-monitoring projects.

Despite my relative ignorance with respect to political parties and elections, I am greatly familiar with a more durable feature of politics in Ghana: patronage. In fact, I am more familiar with the workings of the patronage system in Ghanaian politics than with any of the other central processes and institutions of the country's politics. Tellingly, one of the first big-sounding phrases in the English language that I heard growing up in a small village in the Eastern Region of Ghana was the phrase 'unflinching support'. I figured early on that it must be an important phrase because it cropped up in the speeches made on behalf of the chiefs and people of the area whenever important government officials or politicians were visiting the village. Typically, a pledge of the 'unflinching support' of the chiefs and people of the area/village would precede the list of coveted items of development being solicited from the government through its visiting representative. I have continued to hear that phrase throughout my adult life. It is always said in the context of swearing undying loyalty to the government of the day - military or civilian, authoritarian or democratic - and undying support for the different political personages, ideologies, policies and programs they represented. The phrase was very much used in wel- 
come speeches at 'durbars' in 1977 and 1978, when the supporters of the SMC military went round to canvass support for the Union Government idea. One chief is reported to have pledged unflinching support for Union Government even after admitting that he did not understand the concept. In the 1980s Ghanaian chiefs and peoples were still pledging unflinching loyalty to the PNDC and in the 1990s to the National Democratic Congress (NDC). I have therefore come to regard it as the one phrase that best underlines the prevalence of patron-clientelism, patronage and neopatrimonialism in Ghanaian political life. Unflinching support is something of a currency used in the exchange of political favours. It is the proverbial shield behind which scoundrels, charlatans, rent-seekers, and supplicants in Ghanaian politics hide their true colours. More important, the phrase helps me to remember that patronage has been and remains an enduring characteristic of Ghanaian politics since independence, more than perhaps any other feature.

\section{What do we know of political parties, elections and patronage in new African democracies?}

Political parties: Political parties in contemporary African democracies can be grouped into two. The first group comprises older parties that emerged victorious from the liberation and independence movements. Born, nurtured, and matured during the era of dominant one-party, de facto or de jure single party, and authoritarian states, these parties have survived into the new era of multi-party democracy and even beaten off challenges from new pro-democracy and opposition movements. Examples include the Zimbabwe African National Union - Patriotic Front (ZANU-PF), Kenya National Union (KANU), United National Independence Party (UNIP), Chama Cha Mapinduzi (CCM) and Parti Democratique de Côte d'Ivoire (PDCI). A subtype of this group includes parties like South-West Africa People's Organization (SWAPO), FRELIMO (Frente de Libertação de Moçambique) and the African National Congress (ANC).

The second group comprises new parties cobbled together out of prodemocracy groups and opposition movements. Many of them emerged in the early 1990s and, in some cases, toppled incumbent authoritarian parties. Examples include the Movement for Multi-Party Democracy (MMD), National Patriotic Party (NPP), Alliance pour la démocratie au Mali/Alliance for Democracy (ADEMA), Alliance for Democracy (AFORD), Social Democratic Party (SDP). 
Different as they may be, the two types of African political parties share several common features. They tend to have weak bureaucratic and other organizational structures (even where they can boast of physical infrastructure); and they lack organized membership rosters and regular mechanisms for collecting membership contributions. Indeed, most of these parties hardly rely on membership dues but typically there are no party volunteers. And as one might expect in societies in which patronage is deeply rooted, most party activists and grassroots supporters expect upfront monetary payment, payment in kind, or future material reward in return for services rendered to the party.

African political parties have authoritarian legacies, manifested in frequent attraction to 'strong' and hegemonic leadership. Internal democracy tends to be poorly developed and there is over-emphasis on loyalty to the party and especially loyalty to the party leader. Thus, some supposedly democratic political parties have self-appointed political leaders, major decisions are not subject to internal debate, information is not readily shared, some have lifelong chairpersons and patrons. Indeed, some of the most prominent parties in Africa's new democracies, such as South Africa's African National Congress and Ghana's National Democratic Congress, affect Marxist-Leninist tendencies - placing a high premium on party loyalty and frowning upon internal dissent. A key reflection of the above mentioned factors is that African political parties are characterized by weak internal democracy.

Indeed, African parties tend to be dominated by personalities (as in Chiluba's MMD, Rawlings' NDC, or Nujoma's SWAPO) and their structures and leadership are dominated by older men/old guard politicians - even where the latter groups of leaders have ridden to power on the backs of the youth. The youth are often marginalized in African parties, even though parties tend to have 'youth wings', and women often lack opportunities to train and rise to leadership positions or appear on party slates, even though many parties have 'women wings'.

The continent's parties are largely conceived and organized as vehicles for capturing the state. Contrary to what conventional political theory prescribes, they are hardly conceived and developed as mechanisms for representation, conflict resolution, opposition and accountability, or institutionalization of democratic behaviour and attitudes. Consequently, there tends to be very little party activity between elections. Furthermore, African political parties rarely present policy alternatives and the few who have sought to win power by campaigning on policy or ideological platform have rarely 
been successful. In addition, parties have weak policy analysis capability, and almost as a rule, they lack party policy think tanks. African political parties also tend to have a pronounced ethnic base in spite of constitutional and legal provisions - at least in part, because they lack policy or programmatic content.

At the system level, African political parties have generally proved incapable of marrying the representative with the participatory elements of liberal democracy; they tend to be urban-based or suffer from inadequate linkage with rural society, and they lack citizen participation especially between elections.

They are also often devoid of equitable financing arrangements. Thus, where state financing is provided, it tends to over-advantage ruling parties; where there are no state funding arrangements, campaign resources are secured on a freewheeling and self-help basis, with the incumbent siphoning off state resources and extorting from private business, while opposition parties forage. Moreover, political parties are poorly regulated by either an election authority or the regular courts.

Opposition parties suffer high levels of popular mistrust in Africa, reflecting the internalization of propaganda by monopolistic incumbent governments, as well as the cynical desire on the part of the public to go with the winner and patronage dispenser. The pervasive mistrust of opposition in Africa is confirmed by evidence from Afrobarometer Round 1 and 2 (2002; 2004) survey data. For example, Ghanaian political parties in opposition to the incumbent New Patriotic Party (NPP) scored very low in the public's trust rating in the Round 2 survey, with a total of just 28 percent of respondents collectively trusting them more than 'a little bit'. The same, or a worse, picture emerges from the other African countries included in the survey with only 27 percent in Namibia, 22 percent in Cape Verde, 16 percent in Nigeria, 15 percent in Uganda, and 13 percent in South Africa trusting the opposition.

A similar popular bias against opposition parties and in favour of ruling parties in Ghana can be detected in the sharp reversal in support for the NDC less than two years after leaving power, and in popular identification with the ruling NPP. It is instructive that in the Ghana Round 1 Afrobarometer survey undertaken in 1999, 35 percent of respondents identified with the ruling NDC and 25 percent with the opposition NPP; while in the 2002 Afrobarometer survey, 46 percent identified with the NPP versus 15 percent for NDC. 
Elections: Elections are now widely accepted as central to the project of democratization, and they are invested with unrealistic expectations and powers to resolve all sorts of problems - such as helping to end civil wars, overcoming 'adjustment fatigue', and renewing commitment to and enhancing local ownership of neo-liberal economic reforms.

However, elections in Africa suffer from weaknesses of their own separate from, but related to, the weaknesses of political parties. Elections tend to be rigged, and incumbents have been keen to rig to the extent that they can get away with it - which has often fuelled post-election conflicts, and in some cases, triggered violence.

Election campaigns have tended to be issueless, and parties and candidates that have attempted to win elections by campaigning on policy or ideological platforms have not been successful. Indeed, parties and candidates focus on personalities, symbols and obscurantist heritage and platforms largely because they lack policy or programmatic vision. Thus, some Nkrumahist parties claimed to have channelled the spirit of Kwame Nkrumah for the magic wand to resolve Ghanaian problems, KANU considered it useful to bring in Kenyatta junior as presidential candidate, and a Kaunda 'junior' leads his father's old party - UNIP.

African elections are characterized by direct or indirect mobilization of ethnic votes, partly reflecting the issueless nature of campaigns as well as the inability of parties to articulate convincing policies and programmes, and partly reflecting the continuing relevance of ethnicity in African society and to voters. Correspondingly, patterns of voting in elections tend to be ethnic and regional in a pronounced manner.

In addition, African election authorities tend to lack independence, with many of them located within the Executive Branch of government, and election administration is generally weak in terms of logistics planning, implementation, and monitoring.

Election authorities and judiciaries are usually unable to resolve election disputes speedily and fairly, thereby creating an incentive for parties and candidates to focus on being declared winners by hook or by crook - and to use control over state power and incumbency to ward off postelection challenges.

Disturbingly, African elections too often cause or aggravate social tensions and exacerbate fragility. Thus, serious instability has followed multi-party polls in Burundi, Sierra Leone, Congo Brazzaville, Togo, Côte d'Ivoire, and arguably Nigeria. These may represent the worst examples of election-induced instability and violence, but in fact, there are only a few 
African elections that have not been tainted by this problem. Indeed, disappointment with electoral systems has been a source of disaffection with politics in general, and of pervasive cynicism about democratic political processes and associated institutions.

Patronage: As Richard Sandbrook (1999), Sandbrook and Oelbaum (2001) and others have pointed out, the attempts to liberalize economies and politics in Africa since the post-Cold War period have been largely premised on the need to attenuate entrenched neopatrimonialism and patron-clientilism in Africa societies. Thanks to Chabal and Daloz (1999), and other keen students and analysts of African politics, we are aware that neopatrimonialism remains entrenched in African politics, including politics in the so-called new democracies. Again, thanks to Michael Bratton and Nicolas van de Walle (1997), van de Walle (2001), Sandbrook (2001), Nugent (2001), Lindberg (2003) and others, we are quite knowledgeable about the pervasive influence of neo-partimonialism and patronage in elections in recent African elections and their aftermaths.

I myself have conceded this reality, albeit in passing, in my own essays on Ghanaian and African democratization. For example in my chapter in the recently published edited volume Democratic Reform in Africa: The Quality of Progress (Gyimah-Boadi, 2004:22), I wrote:

Above all, neopatrimonialism and patronage retain a strong hold on African politics, notwithstanding neo-liberal and other reforms. Indeed, neopatrimonialism remains largely entrenched in the politics of both semi-democratic and semi-authoritarian African states. Its inherently self-destructive concomitants, such as corruption, rent-seeking behavior and opposition to economic and administrative rationalization among ruling elites, remain largely entrenched. Many of Africa's new leaders (democratic or not), also continue to be surrounded by assorted 'big men'. For example, in Uganda, President Museveni's brother has been a key figure in that country's command in the war in the Democratic Republic of Congo, President Campoare's brother is the head of the dreaded national security system in Burkina Faso, President Rawlings' wife held sway in Ghanaian politics throughout her husband's tenure in office as an elected leader. Indeed, the prevailing understanding of how political authority is acquired or exercised remains largely colored by the legacy of neo-patrimonial regimes that dominated post-independence governance in most African countries: more or less hereditary rulers rule until they die or are overthrown unconstitutionally; public and political office serve a deeper 'functional' (rentier?) purpose for their incumbents who resist constitutional term limits, retirement and voluntary resignation and/or regard such moves as 
synonymous with economic suicide and loss of an ability to play patron in a patrimonial political culture.

Of course, election irregularities are not confined to Africa, as the State of Florida reminded us in 2000. But, it is a rare election in Africa in recent memory that was not marred by perceived or actual rigging. Elections in Africa continue to significantly reflect the overwhelming advantage incumbent parties enjoy over patronage resources - which then enable them to manipulate electoral institutions, electoral rules and procedures; to siphon off state resources and deploy them into partisan use in elections; to commission development projects, many of them off-budget, especially in an election year; to extort donations from private business people and rentseekers; and to invest in businessmen who can be counted upon to decant resources back into the party coffers. It also allows the ruling party to use subtle and crude means to disorganize and destroy opposition parties; to deny the opposition the oxygen of media coverage; to deploy state security agencies and sometimes the courts to harass the opposition; and to block private sector sources of funding for the opposition by destroying businesses of those not aligned with the ruling party or suspected to be sympathetic to the opposition.

In this setting, it is easy to see why and how patronage capacity easily becomes the single most important factor in electoral outcomes. It is also easy to understand why the incumbent party becomes preoccupied with building patronage capacity and dispensing patronage immediately after elections: the winning party, with its leader at the centre, simply embarks on a new round of political consolidation; and ruling party supporters line up for presidential appointments, while businessmen line up for government contracts and all manner of concessions (tax waivers, loan cancellation, protection from criminal prosecution, etc). If there has been a change of parties in power, political allegiances shift gradually and sometimes dramatically to the de facto ruling party and president. Messages of congratulations are sent to the winning party and its leader; people enthusiastically display ruling party flags and pennants. Simultaneously, flags and pennants of the opposition parties quietly disappear from public view. The former ruler and his party are loudly denounced and their record in office trenchantly attacked. There is also fulsome praise for the new government even before it has acquired a record. A spate of dramatic and subtle defections from opposition parties to the ruling party ensues. Thus there is a veritable national enactment of the play entitled 'Everybody Loves a Winner'. 
The above portrait of African parties and patronage-ridden elections would seem to confirm the thesis that democratization has failed to make a dent in entrenched neopatrimonialism in African politics. It may even suggest that, far from the expected reduction, democratization and especially multi-party and electoral competition reinforce neopatrimonialism in African politics.

But is this really the case? Is it the only reality in contemporary African politics? Is African politics that static? Is neopatrimonialism all that impregnable? Are political liberalization efforts in Africa really doomed to failure? Is it really impossible to construct politics in Africa so that neopatrimonialism can be countered and checkmated? Most importantly, can the effectiveness of patronage capacity in African multi-party elections be blunted?

\section{Blunting the effectiveness of patronage in multi-party elections}

Obviously, a number of incumbent patrimonial regimes (Chiluba, Rawlings, Moi) have been dislodged in elections in recent times, despite their overwhelming patronage capacity and other advantages in the neo-patrimonial context. How does this happen in a neo-patrimonial context? What are the dynamics at work when overwhelming patronage advantages fail to translate into electoral victory? Instances of electoral defeat of incumbent parties and presidents may be rare, but the fact that they do occur at all suggests at least the possibility that patronage capacity is not an impregnable fortress after all - or at least under some circumstances. But what are the circumstances under which electoral change can occur in spite of or even because of patronage? Can we research and model the conditions under which opposition parties are able to dislodge incumbents, and electoral turnovers are secured, as has occurred in recent years in Senegal, Ghana, and a few other countries?

Of course, it will take a huge amount of research, analysis and reflection, drawing from national and cross-country data on parties and elections in contemporary Africa in general, and elections in new African democracies, to begin to answer the above questions with any depth. Indeed, my own reading of the Ghanaian scene confirms most of the analysis of African multi-party elections and democratization which assigns a huge influence to the manipulation of incumbency and to the patronage capacity that incumbency confers. Yes, my own reading does confirm that patronage has been an important facility for winning power and maintaining power in 
my country. It was certainly a key factor in the NDC election victory in 1992. For example, extra budgetary expenses such as the over 60 percent across-the-board hike in public servant salaries in the few months ahead of the first transition polls helped in overcoming middle class antipathy to the Rawlings' party. Indeed, the prevailing economic and social conditions (such as very low incomes, a weak private sector, high dependency ratios, weak social insurance, low literacy rates, and a large rural population) virtually guarantee that patronage capacity will remain highly influential in determining the fortunes of political parties in competitive elections.

But my reading of multi-party politics in Ghana and the three elections conducted within the same framework since 1992 also suggests that patronage capacity is not as unassailable as we assume. It shows that patronage, after all, can function as a double-edged sword. The above-mentioned election-time wage increase created complications in economic management for the elected Rawlings' administration in 1993-1996. The botched attempt to contain the ensuing fiscal crisis by introducing a 17 percent VAT triggered mass protests in 1995. That and the related resignation of long-time Finance Minister Kwesi Botchway provided considerable ammunition for the opposition in the 1996 election campaign. Similarly, intense struggles within the NDC in 1996 and 2000 over the limited number of patronage-rich party and state offices at the national and constituency levels, parliamentary seats, and the presidential candidate provoked serious disaffection among party members, and politically damaging defections and schisms. Above all, perceived patronage-induced corruption within the NDC administration and accompanying economic mismanagement gave more than usual credibility to the NPP's message of 'positive change' in the 2000 polls. Thus, patronage may have helped the NDC to buy loyalty and votes in three elections, but patronage undermined economic management and performance. In addition, the capacity to dispense patronage dwindled over time while competition for those resources intensified. Patronage also corroded the power and legitimacy of the NDC regime, and the cost of maintaining it rose higher and higher with each successive election. The moral authority of the incumbent patronage regime was severely eroded and rendered the opposition parties relatively attractive despite their relative lack of patronage capacity.

Successive improvements in electoral credibility in Ghana after 1992 had been an important complement to the diminishing returns the incumbent NDC derived from patronage. Indeed, reforms in election administration after the controversial 1992 polls, the enhancement of the 
credibility of Ghana's Electoral Commission and increased election transparency - including media, party agent and civil society poll watching and parallel vote counting - helped to make election 2000 relatively clean and to undo the patronage advantages of the incumbent NDC. Similarly, the relative levelling of the electoral playing field - including free coverage in public media and enhanced opportunities for the opposition to campaign - helped to blunt superior NDC patronage advantage and to secure power alternation. Thus, it seems that the bastion of patronage capacity can be broken up under conditions of a reasonably liberal democratic constitution, one that allows opposition parties the freedom to campaign; ensures a levelling of the electoral playing field through, for example, space in the media for opposition parties; and provides equitable party finance regulations, transparent and efficient elections, judicial independence or at least credible adjudication of election disputes, and free and independent media, especially radio. It appears also that as the Ghanaian political system has become increasingly open, and elections and other processes of accountability have become less farcical, citizens have grown increasingly forceful in demanding effective performance from their government. Furthermore, the practice of neopatrimonialism, patronage and corruption has become subject to public censure.

So could it be that as students of African politics, we are not paying adequate attention to the positive aspects of African democratization, and in particular to the ways in which clean elections and other countervailing and public accountability facilities help to attenuate the influence of patronage and erode neopatrimonialism? I offer this as a challenge and a proposition for serious empirical testing.

\section{References}

Afrobarometer Network (2004), Compendium of Results from a 15-Country Survey. Working Paper No. 34.

Afrobarometer Network (2002), Compendium of Comparative Data from a TwelveNation Survey. Working Paper No. 11.

Bratton, M. and van de Walle, N. (1997), Democratic Experiments in Africa: Regime Transitions in a Comparative Perspective. Cambridge: Cambridge University Press.

Chabal, P. and Daloz, J.-P. (1999), Africa Works: Disorder as Political Instrument. Bloomington: Indiana University Press.

Gyimah-Boadi, E. (2004), 'Africa: The Quality of Political Reform', in Gyimah-Boadi, E. (ed.) Democratic Reform in Africa: The Quality of Progress. Boulder: Lynne Rienner Publishers, pp. 5-27. 
Lindberg, S. (2003), 'It's Our Time to Chop: Do Elections in Africa Feed NeoPatrimonialism, Rather Than Counteract It?', Democratization 10: 2, pp. 121-140.

Nugent, P. (2001), 'Winners, Losers and Also Rans: Money, Moral Authority and Voting Patterns in the Ghana 2000 Election', African Affairs 100, pp. 405-428.

Sandbrook, R. (2001), Closing the Circle: Democratization and Development in Africa. London and New York: Zed Books, and Toronto: Between the Lines.

Sandbrook, R. and Oelbaum, J. (1999), Reforming the Political Kingdom: Governance in Ghana's Fourth Republic. Accra: Centre for Democracy and Development.

Van de Walle, N. (2001), African Economies and the Politics of Permanent Crisis, 19791999. New York: Cambridge University Press. 


\title{
Party Research: Western European Bias and the 'African Labyrinth'
}

\author{
Gero Erdmann ${ }^{1}$
}

\section{Introduction}

Perhaps more than most other sub-fields of political science, political party research has had a very pronounced western European bias. It is not only the fact that major research works refer to parties and party systems in western Europe, but even party models, models of party development, and party systems were constructed on the basis of western European experience. ${ }^{2}$ This began to change only when party research was refocused by the newly emerging parties and party-systems during the 'third wave' of democratization. The political parties of the United States had earlier provided an alternative model, namely one based on the concept of 'political machine' instead of the European 'mass party' concept, but research along that track remained a side-line to mainstream party research.

When political party research was applied to the newly emerging parties in Africa in the 1960s, the concepts based on the European mass party model (although partly modified or even simplified) failed to cope with African realities. ${ }^{3}$ Even if an ostensibly non-European model was constructed, scholars did not manage to escape the predominant paradigm of the 'mass

1. We are grateful to Frank Cass publishers for permission to reprint this article which was first published in Democratization, vol. 11, no. 3 , June 2004, pp. 68-87. Research for this article was carried out within the project 'Political parties in Anglophone Africa - Botswana, Ghana, Malawi, Tanzania and Zambia' sponsored by the German Research Foundation (DFG, Deutsche Forschungsgemeinschaft).

2. Sartori (1976); Beyme (1982, 2000); Panebianco (1988); Mair (1994: 1-22, 1997); Katz and Mair (1995: 5-28).

3. Hodgkin (1961); Morgenthau (1964); Coleman and Rosberg (1964); LaPalombara and Weiner (1966: 3-42). For early critics of the application of the concept in 
party' which flourished during the 1960s and 1970s (LaPalombara and Weiner 1966: 6; Emerson 1966: 274). The crux of the matter was that political scientists were blinded by the claims of party politicians. In spite of the absence of strong empirical evidence most of them took the latter's pretension of having a mass party as reality - or as Giovanni Sartori put it, 'a mass or a mobilizational momentum has been mistaken for a mass or mobilizational nature of parties' (Sartori 1976: 255).

Apart from the obvious lack of empirical research one of the main problems related to the applied concept of the 'mass party' was the inherent focus on formal institutions. This, of course, was a problem of party research in general, but it became more obvious much earlier in Africa or research on parties outside Europe more generally. One reason was that formal institutions did not play a major role in the social and political process of the parties in Africa - in fact they played a minor role, if any at all. Although informal institutions are crucial in European parties as well (an aspect which has only recently become a focus of attention) the formal structures provided a lot more material for study as compared with parties in Africa.

The importance of informal institutions for the operation of political parties in Africa was introduced to party research in Africa by Henry Bienen and René Lemarchand in the early 1970s, albeit without much impact at the time (Bienen 1971: 195-214; Lemarchand 1972: 68-90). ${ }^{1}$ This was a period when African party research was in decline, partly due to the conceptual problems and, probably more importantly, due to the political situation and the research subject itself: the predominance of authoritarian one-party rule. Consequently, the impression was created that the established instruments of party research were not suited to an African context. Perhaps Sartori's relevant point about the 'fluidity' of the African situation had a too strong and inhibiting, as well as lasting, effect. For until recently, the old discussion about the methodological applicability of established party research instruments was not taken up by the revitalized research on political parties. Anyhow, this revitalization after the late 1960s has been surprisingly slow, sparse, and late in arriving. It has come to the forefront only since the late 1990s, after almost ten years of democratization and the proliferation of parties and party politics.

Africa see Wallerstein (1966: 201-214); Bienen (1967: 214-230); Sartori (1976); Nuscheler and Ziemer (1979: 126-178).

1. See section "Formal and informal politics" on p. 48. 
Interestingly the current focus of systematic research is predominantly on party systems. Rarely do we find any attention to other topics, apart from the role parties play in elections. However, the basic question about the conceptual framework for political party research in Africa remains unresolved. This article tries to tackle this problem by addressing four questions. The first question is about the function of parties in Africa. Do they perform the same political and social functions as in established western democracies? The second relates to the social or political basis of party formation and structuring of party systems. The third question is posed by the shortcomings of the typical focus on formal institutions. The problem is how this can be overcome or modified. And the fourth question is, do we need a specific model of an 'African party', or even a distinct African party typology separate from established typologies? In addressing these four questions the article argues that despite the very specific western European bias, the field of political party research provides - after some necessary modifications - a sufficient conceptual framework for an understanding of political parties in Africa.

Before addressing these questions it may be helpful to remind readers of the characteristic features of political parties in Africa as discussed in the literature and from the writer's own research in several African countries. ${ }^{1}$ This understanding of political parties provides a background for the further discussion of the methodological problems encountered in research on African political parties. There are a number of typical characteristics which apply to most parties:

- barely distinguishable programmes, which in most cases bear no relation to their policies;

- weak bureaucratic organization, which in many cases operates only on a temporary basis;

1. The information was gathered during various research projects throughout the 1990 s in Tanzania, Zambia, Namibia, Malawi, and Ghana. Very valuable information from inside political parties was generously shared by Neo Simutanyi (University of Zambia); in addition I benefited from Max Mmuya's (University of Dar es Salaam) and Nandini Patel's (University of Malawi) research. The relevant literature based on detailed empirical research on parties includes the following titles: Chaligha and Mmuya 1994; Fondation Friedrich Ebert 1995; Wanjohi 1997; Schmidt 1997: 251-292; Mmuya 1998; Kadzamira, Mawaya and Patel 1998; Henning 1998; Erdmann 2002a; Moegenburg 2002; Emminghaus 2002: 287-309; see the issue of Democratization, Vol. 9, No. 3 (2002), and Salih 2003. General treatments of questions related to parties a nd elections as well as the numerous works on South Africa are omitted here. 
- informal relations (partly based on clientelistic relations and patronage) predominate the party structures;

- strong personalism dominates formal internal structures;

- high degree of factionalism;

- lack of internal democracy;

- unreliable membership data, because there is either no formal membership or in many cases multi-memberships (card-holding of several parties), thus 'membership' is weak apart from a small group of staunch party cadres;

- predominantly regional and/or ethnic-based membership and electorate;

- weak funding base, which is not based on contributions of a broad membership but on the self-interested donations of rich individuals;

- weak formal linkages to civil society.

There are of course exceptions to these features. It seems that in particular some of the former 'state parties' of one-party regimes still maintain a number of comparatively strong bureaucratic features, for example Tanzania's Chama Cha Mapunduzi (CCM) (Erdmann 2002a). Often the ruling party appears to have a better bureaucratic organization/structure than the opposition parties. But this impression could be misleading. Ruling parties usually deploy state finances to their own benefit and rely heavily on government structures for their operations as well. Even a brief visit to the often dormant and even derelict headquarters of ruling parties will supply visual clues; the usual (that is, abandoned) state of the party after the loss of power confirms it.

The foregoing list of characteristic features is at best provisional. More empirical research is required. But at least we now possess the raw material for formulating hypotheses on political parties in Africa in terms of what they are, how they operate, and what makes them generally distinct from European political parties (most notably the concept of mass party), which provide the conceptual background for party research. At the same time the overall picture fits into the more general results of party research on parties in new democracies of the 'third wave'. Compared to parties in the old democracies, parties throughout what Schmitter calls the 'neo-democracies' of eastern and southern Europe, Latin America and Asia are presumed to have certain features in common: fewer members; weaker organizations; less distinct programmes; weaker linkages with (civil) society; and weaker 
party identification and thus a higher volatility (Schmitter 2001: 67-89; Mair 1997, quoted in Merkel and Sandschneider 1997: 10; von Beyme 2000). So, parties in Africa's multiparty systems - whether authoritarian, hybrid or democratic regimes - seem not to differ very much from parties in new democracies elsewhere.

\section{Party functions}

The first question is whether African political parties can be denoted as 'party' in the sense of a political party in a western democracy on the grounds that they perform the same basic functions. A very general definition of a party without a strong normative connotation can be construed as follows: 'A party is an association of like minded people who pursue common political goals and for which they, usually, try to get into government' - that is, a party is to be regarded as an instrument to gain power in order to exercise political domination within a state. ${ }^{1}$

The repeated mushrooming of new political parties by spontaneous formations, splittings, and merging since the early 1990s indicates that most of Africa's political elites regard parties as the most important vehicle to gain power. In this fundamental issue there is no major difference to elites in western democracies. The question is whether this understanding is shared by the population at large. If one looks at the electoral participation, it seems to be obvious that at least the electorate perceives the existing political parties in a similar way as the political leaders do. It can easily be assumed that they participate in the elections because they want to see their favoured party win; the expectation is, of course, that they will get something from the victory of their party. Party politicians elected into government are expected to deliver something to the people who voted them into power. There is empirical evidence to support this proposition. In a number of focus group interviews the author held in two rural and one urban setting in Zambia, people spelt out quite clearly this very general understanding of a political party. For example respondents called parties a 'group of people that come together to form a government' or 'a group striving hard to bring something good to the country'.

1. Weber 1980: 167, 1978: 248-249; Sartori 1976: 24-29; Beyme 1982: 22-26; Ware 1996.

2. The discussions were held together with Neo Simutanyi (University of Zambia) and Matthias Basedau (Institute of African Affairs, Hamburg) in the following locations: Chibombo, Chibombo District, Chinyunyu, Chongwe District, and in 
What people expect or what people might perceive of political parties varies and above all may differ from the role parties are actually performing within a political system. However, whether there is congruence between the model of the institution and its role in the wider political system on the one hand and on the other, what actors, people as well as leaders, expect from, and perceive of, the institution, is of course potentially very significant for the functioning as well as legitimacy of institutions.

Out of the plethora of possible functions the following, all related to a democratic regime, are generally agreed among scholars: ${ }^{1}$

- providing ideological orientation and political goals (symbols);

- socialization and mobilization;

- aggregation and articulation of interests;

- elite recruiting and government formation. ${ }^{2}$

As regards the first, it is doubtful that the majority of African political parties perform this function. As noted above, one of the characteristics of political parties is that their programmes and ideologies do not differ very much and do not appear to matter very much. Max Mmuya has labelled the programmes of Tanzanian parties as a peculiar 'mutation of social democracy and liberalism' (Mmuya 1998: 27). This applies to many parties in

Lusaka mid March 2003; together 29 males and females participated. Respondents mentioned numerous other points about party functions: parties are to 'represent people's interest', 'unite or organise people', 'pick up problems and present them to the government', 'address specific problems such as education', 'bring development', 'recruit leaders', 'implement ideas', 'campaign in elections'.

1. Apart from some differences see Schmitter (2001: 72-73); Beyme (1982: 22-26); Bartolino and Mair (2001: 331); Almond and Powell (1984: 81-86). Randall and Svåsand (2002b: 4) identified function two as 'electorate oriented', function three as 'linkage-related, and four as 'government-related'; function one, which they, surprisingly, did not include, would then be related to all three 'levels'. Wiesendahl (1980: 188), for instance counted 18 different functions in the literature. Some of the functions can usually be grouped together, as with the seven functions in Diamond and Gunther (2001: 3-39). For additional observations on the government function see Dalton and Wattenberg (2002: 5); Schmitter (2001: 72), makes the valid point that all tasks of the party literature can only be performed by some of the 'super-parties' such as the German or Swedish Social Democratic Party.

2. For a discussion of functions of political parties in a wider context that includes authoritarian regimes in Africa, see Tordoff (1984: 109-136). However, almost all functions discussed in this general way are applicable to both democratic and authoritarian regimes and can be subsumed under the four core functions. On the ambiguity of the 'patronage function' being 'boosted' by the revival of multi-partyism (ibid., 127-133) see below. 
other countries observed by the writer. However, this lack of ideological or programmatic specificity is not unique to African parties. The blurring of ideological and programmatic distinctions is also observable in other newly democratizing and consolidating regimes, and to a lesser degree in mature democracies as well.

The second function - aggregating and articulating interests - is based on societal interests of different classes or social strata and usually linked to organized interest groups of civil society. But Africa is different. First of all, civil society groups are weakly organized; the classical pressure groups play only a rather marginal role. Secondly, as Widner has argued, because they are so weak, parties need not relate to these groups. Instead, parties find social and political support through other means, for example, via patronage, clientelist relations and similar appeals. This may or may not be direct and open; it may be based on ethnic or regional identity (see below party formation) (Widner 1997: 65-82). If this holds true, parties might be aggregating and articulating interests of particular identity groups such as ethnic, regional or even religious groups to be represented at the power centre of the political entity and gain access to the centre's distribution of resources.

In regard to mobilization and socialization, it is obvious that notwithstanding their bureaucratic inefficiencies and general organizational shortcomings the major political parties demonstrate the capability to mobilize a surprisingly high voter turn-out in elections. At eleven 'founding' elections in Africa in 1995-96 the average turn-out was about 67 percent, while for second elections in some other countries the turn-out was 61 percent of registered voters. ${ }^{1}$ For some observers this turn-out is disappointing because when related to the number of eligible (but not necessarily registered) voters it translates to around $40-45$ percent. This, of course, is a question of the criteria of measurement. However, it does not compare all that badly with voter turn-out in some of the mature democracies, especially the United States. And we should not ignore the many considerable difficulties voters often encounter, not only in rural areas but where the election system and political and administrative organization pose obstacles, such as in the registration processes. ${ }^{2}$ The really interesting question, then, is how do parties achieve the mobilization of voters?

1. Calculation is based on figures provided in Bratton and Posner (1999: 382-391).

2. The decline in voter turn-out between the first and the second election should not be misunderstood. In fact it is not surprising because the first or 'founding' elec- 
While there is little doubt that political parties perform the mobilization function for elections, little information is available on whether they mobilize for other purposes as some used to do in the past, for example for self-help in agricultural development in Tanzania or harambee in Kenya (although the effects on the relationship between party and people were often ambiguous). Moreover, it is very difficult to see what they actually achieve as regards socialization: research has not specifically addressed that issue. What can be tentatively inferred from weak organization and weak links to civil society and to ancillary organizations is that such parties lack the means to socialize their members, and the socio-political milieu surrounding them, into a political force in support of democracy. This seems to be more true if we consider that most of the parties do not have an ideology and programme that differentiate them from one another and give their members, supporters and voters a clear value system on the basis of which to judge what happens in politics. The function of socialization into democracy is also unproven. The absence of inner party democracy is typical, and party members are unlikely to receive special training in democratic behaviour, norms and values.

The overall impact on the electorate is equally unclear. On the one hand most people seem to support democracy and party competition (opinion polls such as the Afrobarometer make that quite clear) (Afrobarometer 2002). However, this can hardly be attributed to the work or influence of parties. The origins lie elsewhere, such as in the 'negative socialization' by the previous authoritarian regime. But people also become cynical about the behaviour of party politicians as well as about the continuous splitting of parties, about politicians switching from one party to the other and back again in quick succession. This claim is supported by all sorts of conversations with people in different countries and comes out very strongly from the focus group discussions in Zambia. There people feel that parties and party politicians are selfish, they do not do what they are expected to do, namely to be 'servants of the people', as one person put it, and most of the discussants felt that there are too many parties in the country. ${ }^{1}$ A negative

tions are novel and cause much excitement. A decline in the second election can be considered as going back to normal.

1. The background to this was that before the 2001 elections four new parties split off from the ruling party, Movement for Multi-Party Democracy (MMD); in the end, 17 parties competed for seats in parliament of which some won seats. So far the parties in their current state seem to make no major positive impact in socialising people in support of multi-party competition and democracy. 
image of parties seems clear. But we should be cautious about drawing negative conclusions concerning perceptions of and attitudes towards democracy, because even in consolidated democracies parties belong to the least trusted institutions.

The final functions, elite recruitment and government formation, need no lengthy discussion because it is evident that the political parties do fulfil both. Political leaders come out of political parties; members of parliament as well as presidential candidates are nominated by parties, albeit some party leaders and candidates appear to have been almost self-appointed. The electoral system, which in most countries is simple or absolute majority rule within a presidential system, means that it is not overly difficult to form a government. The trend towards predominant party systems provides additional grounds for the proneness of presidentialism to institutional crisis - which is well known in other continents - does not happen often in Africa (Erdmann 1999: 388; Bogaards 2004: 173-197). ${ }^{1}$

Starting from a general understanding of what a political party is, even what people think a party is all about, the established functional approach of party research helps to paint a differentiated picture of political parties and their social and political role in Africa. However, this does not exclude other political function of parties that are not performed by parties in western Europe. For example, the distribution of patronage could possibly be added as a particular function of parties in Africa. ${ }^{2}$ This might be not be appropriate to a 'proper' democracy governed by the rule of law and legal rational governance, but it is nevertheless part of the realities of party politics and an integral part of neopatrimonial rule, which predominates in many of Africa's polities. Thus, as a descriptive-empirical function it ought to be included in the catalogue of party functions.

A further consideration should be whether to add 'organizing opposition' (and formulating political alternatives) as an additional function to the ones already mentioned. ${ }^{3}$ Although this could be subsumed under the

1. For a detailed discussion of the effects of different electoral systems in Africa with a sceptical view on the actual relevance of electoral engineering see Basedau (2002: 311-333).

2. This idea is not new, but not part of the functionalist approach. For Max Weber, the distribution of 'patronage' was an obvious activity of parties, the 'patronage party' even a type in its own right; and party competition about goals was always competition about patronage of offices as well; Weber (1980: 167, 839); see also Tordoff (1984).

3. Burnell suggested this in a comment on an earlier version of this paper; see also Randall and Svåsand (2002b: 4-7). 
fourth listed function as a precondition for 'government formation', for analytical purposes it could be useful to keep it separate. It makes sense in so far as organizing opposition, especially a loyal opposition, is crucial to control the government and check abuses of power, which is essential for the functioning of democracy. Within the neopatriomonial environment of most African states this analytical dimension - or its absence - becomes even more important. ${ }^{1}$

The discussion about how parties in Africa perform many if not all of the essential functions ascribed to parties, but by means that may differ from elsewhere, raises the question of functional equivalents: this will be discussed after an examination of the cleavage model.

\section{The cleavage model}

The cleavage model of Seymour M. Lipset and Stein Rokkan provides a useful explanation for party formation in western Europe. The authors made no claim that it would be directly applicable to other parts of the world. The model tries to answer the question of how societal conflicts are translated into parties and party systems. The problem is that 'conflicts and controversies can arise out of a great variety of relationships in the social structure, but only a few of these tend to polarize the politics' (Lipset and Rokkan 1967: 6). The cleavage therefore denotes an institutionalized political conflict that is anchored in a society's social structure. This conflict is comprised of at least four dimensions: socio-economic; an interest or value orientated dimension, a party political dimension, and a dimension of voter alignments. The traditional cleavages in Europe were centre vs. periphery (nation state), church (or religion) vs. state (secularization), rural-agrarian vs. urban-trade (primary vs. secondary economy), and finally capital vs. labour as a consequence of the industrial revolution. All four cleavages were articulated in the politics of western European states, and they were held to occur in a historical sequence as indicated above.

The political articulation of cleavages occurs only if political elites take them up and translate them into party politics. Thus there is no automatic transformation of a social conflict into a cleavage that is articulated in the formation of political parties. Political actions and actors are necessary to

1. This function would explicitly relate the functional effectiveness of parties to democracy. For the problems of neopatrimonialism and democracy see Erdmann (2002b: 323-342); for a detailed analysis of the relevance of this problem see Burnell (2001b: 34-64). 
accomplish this. Moreover, a regular reactivation of the conflict pattern encourages the institutionalization of cleavages and thereby generates political identities and party affiliations. Briefly: the cleavage model provides an analytical framework which combines a structural with an actor oriented approach.

The question is whether this model based on the four social cleavages can be applied to Africa. Does it help us understand African party politics? Various authors have pointed out party and party system formation outside Europe differs from the Lipset-Rokkan model (Eith and Mielke 2000; Randall 2001). In particular the sequencing of the cleavages is different: 'Processes of national unification and integration, and of industrial development have not necessarily preceded political mobilization nor indeed have they necessarily been realized subsequently' (Randall 2001: 258). As we have argued elsewhere, the cleavage model cannot be applied in a sequential (diachronic) but only in a heuristic manner as a synchronic model of party formation in Africa (Erdmann and Weiland 2000: 246-262). Although Lipset and Rokkan did not address problems of ethnic or regional politics explicitly, these can be subsumed under the centre-periphery cleavage. 'This cleavage is based on the concept of 'territorial opposition', which is characterized under conditions of universal suffrage as the 'commitment to the locality and its dominant culture: you vote with your community and its leaders irrespective of your economic position' (Lipset and Rokkan 1967: 13). ${ }^{2}$

Most of the traditional European social conflicts - urban vs. rural, religion vs. state, labour vs. capital, and centre vs. periphery - can be identified in Africa as well, but they are weakly developed and thus contribute little, or in a few cases only, to the formation of parties and party politics. ${ }^{3}$ The crucial and predominant cleavage in most African societies is ethnic and/

1. While in Europe this cleavage was about the dominant culture of the centre in the course of nation building, in Africa the conflict is about socio-economic distribution (that is, who is entitled to control the distribution of the resources at the centre). Both conflicts can of course result in secessionism. In some cases such as Ethiopia the conflict seems to be about cultural dominance as well; the Southern Sudan conflict can be seen as another example. Usually, however, because of the multiethnic composition of African states there is no major conflict about the national culture and, related to that, the national identity.

2. We differ here from Merkel (1997: 348), who proposed 'ethnicity' as a fifth cleavage. In Sartori's (1976: 18-19) interpretation of the cleavage model ethnicity is presented along with race and region as a cultural conflict.

3. For a detailed discussion see Erdmann and Weiland (2000: 253-257). 
or regional identity. The implication is not that political parties in Africa are ethnic parties, but that they mobilize along lines of ethnic identities, 'morality', or solidarity. In fact, 'ethnic parties' - parties dominated by one ethnic group and with a particularistic agenda - are rather an exception in Africa. The predominant feature is a coalition of several ethnic groups of different sizes that has been negotiated by their respective elites: they are 'multiethnic parties.'

Ethnicity is here understood not as a primordial or essentialist attribute but as a historically and socially constructed identity, which is multifaceted, changeable, and has multiple meanings. Ethnicity is constituted by the interaction of self-ascription and ascription by others (Young 1976; Lentz 1994: 25; Lentz and Nugent 2000: 2-6). Ethnicity is of course not a question of fixed boundaries or neatly delineated entities. Thus ethnic cleavages are variable; ethnicity can, but need not, lead to party formation. This depends on the development of ethnic identities. There can be a simple ethnic consciousness which implies that people know they are different from others, but do not have an elaborated cultural ideology about themselves; there is an ethnic self-consciousness which has a developed cultural ideology about itself, and finally there is the politically mobilised ethnicity with a chauvinistic world view. ${ }^{2}$

There is no clear-cut pattern of how ethnicity affects and structures party formation. This can only be analyzed in a historical perspective that takes the particular contingencies of each case into account. And these in turn depend on the particular constellation of ethnic groups in each country, their numbers and sizes, how they relate to each other and, very importantly, what sort of socio-economic differences exists between them and how they are perceived. Most crucial is the degree to which ethnicity is politically mobilized; parties and party systems contribute to the development of ethnicity of groups. To some degree, party formation (together with party politics) and ethnicity mutually influence each other, so that party politics can contribute to the process of what has been called the imagination' of ethnic identities and the degree of their political mobilization. The issue is complicated by the fact that several ethnic groups can live adjacent to each other, perhaps giving rise to a regional identity, such as 'northerners' in Malawi. Other multiethnic parties draw their support from ethnic

1. I follow here Horowitz (1985: 291ff.), where multiethnic parties have an advantage over ethnic parties, namely 'some commitment to ethnic accommodation'.

2. Other terms could be 'moral ethnicity', 'political tribalism' and politicised ethnicity; see Lonsdale (1992: 466-467). 
groups which do not live next to each other in one area but are dispersed, like the ethnic coalition of Kenya African National Union (KANU). At the same time, an ethnic group can be subdivided into subgroups, because of internal conflicts or sharp cleavages. The result can be that each subgroup belongs to a different ethnic (party) coalition: ethnic groups and parties in Kenya provide an example. Although there is a substantial literature on ethnicity, apart from the work of Horowitz there is hardly any research on this particular relationship between ethnic groups, politically mobilized ethnicity, party formation and party politics. ${ }^{1}$

Two topics have to be briefly raised before ending this section. First, there is the problem of what keeps an ethnic coalition together despite it seeming to be very fragile. Apart from a few states where there is one big ethnic group that comprises the majority of people, the multiplicity of small ethnic groups makes it necessary to form ethnic coalitions, in order to build up a winning party which can become a governing party. Purely ethnic parties can hardly enlist sufficient votes for a majority. The instrument to keep the coalition together is ethnic patronage politics that is fed from public resources. This is the case for the party or ethnic coalition in power; this again explains why coalition building is so difficult in opposition, it is built on hope only - hope to be part of a future government. Thus coalition building is a simple rational calculation. This again explains to a substantial degree, though not exclusively, the predominance of predominant (or dominant) party systems in Africa (Erdmann 1999: 387-388; Bogaards 2000: 164-166, 2004), ${ }^{2}$ even though there were once warnings of an extreme and disastrous fragmentation of party systems in Africa (Schmidt 1996: 53-54; Widner 1997: 66). ${ }^{3}$ Next to personalism

1. Horowitz, op. cit. For a more detailed discussion of the problems involved see Erdmann and Weiland (2000: 257-258); for a general discussion from an institutional perspective see Mozaffar (1995: 33-69).

2. I modify Bogaards (2004: 164) formulation, which stays with Sartori's Africa terminology of a 'dominant' party system, while in his general typology Sartori used the term 'pre-dominant' for the same situation - an absolute majority in parliament. Sartori justified the different treatment by claiming the 'fluidity' of the 'African labyrinth' in the 1960s and 70s. However after three consecutive elections in many African countries it is doubtful whether 'fluidity' now applies to their party system.

3. The very frequent laments about the large numbers of parties in African countries tends to forget the number of parties registered in Europe: in Germany there are 61 registered parties (2003), and 24 competed in the parliamentary elections in 2002, of which only five gained mandates. If all registered parties are counted as in Africa then almost all European party systems are extremely fragmented; however discus- 
(and closely linked with it) it is ethnicity that gives rise to the distinctive factionalism of African parties, which is one of the main sources of the parties' weakness as has been pointed out by Burnell for Zamiba (Burnell 2001b: 260).

Secondly, if we talk about ethnic or multiethnic parties the implication is not that all people vote along ethnic lines. Voting behaviour is a result of many factors; research here distinguishes between short and long term determinants. However, systematic research on voting behaviour in Africa is basically non-existent. Explanations of election results, why people voted for this and not for the other party, is at best usually an 'informed' guess. The point here is that ethnicity provides the predominant - not the exclusive - social cleavage for party formation and voter behaviour. And it is not only that people believe that other (rural) people vote 'tribal', party leaders also make clear strategic calculations about which person with which specific ethnic background should be included in the ethnic coalition; and then, which particular person is to be placed in which constituency in order to win the elections. Apart from that, there are obviously groups of younger politicians who have attempted to build parties on non-ethnic ties, for instance on issues, although as yet not very successfully. In addition, there seems to be a different voting behaviour in some major cities or urban areas like Zambia's Copperbelt for example. Focus group discussions there reveal that people from rural areas agreed that people vote according to ethnic affiliation - in their words, 'voting is tribal'. However the urban interviewees also claimed the 'tribal voting' is confined to rural areas only; urban people - they themselves say - would vote according to the political programmes (but hardly anyone could tell the interviewers about programmatic differences). ${ }^{1}$ Further investigation of this phenomenon is needed. Sociological research suggests that moving to towns does not automatically mean that the rural village world is left behind; urbanization means, at least for some time, only the extension of village life into the townships or bidonvilles, and even in the Copperbelt some observers claim to see a 'tribalism in town'.

In sum, the traditional cleavage model depleted of its sequential dimension and modified by including ethnicity as the predominant cleavage as outlined above seems to be useful for analyzing current features of party

sions of fragmentation usually consider only the 'relevant parties' which manage to gain sufficient votes for seats in parliament.

1. See footnote 2 on p. 38.

2. Elwert and Segbenou 1983: 119-143; Gluckman 1960: 55-70; Epstein 1958; Lentz and Nugent 2000: 5 . 
formation and party politics. What makes it particularly valuable is the fact that it allows for other cleavages, actual or prospective. The applicability of the model becomes clear when the party formation of the 1950s and 1960s is compared to that of the 1990s in countries such as Ghana, Kenya, Zambia, as well as Zanzibar and Tanganyika (Tanzania mainland); and even, potentially, in Uganda. ${ }^{1}$

A final question is whether we should add to the social cleavages model a political cleavage model for party formation, one that centres on the transformation conflict between one-party adherents and democratizers, as developed for eastern Europe and applied in Africa as well (Kitschelt 1995: 447-472; Emminghaus 2002). ${ }^{2}$ But it is difficult to identify these conflicts being transformed into a permanent cleavage which gives rise to a lasting formation of parties. In the case of the colonial transformation, conflict between 'conservative' colonial collaborators and 'progressive' democratizers or anti-colonial radicals had no lasting impact on party formation. The political background of many of the democratizers in Africa indicates a flexibility in switching from the state-party into the opposition camp and vice versa, which suggest that the political cleavage model has little to offer.

\section{Formal and informal politics}

For a long time party research was focused on formal institutions. Almond and Powell who were responsible for the functional approach in party research assumed that in the process of socio-economic modernization the function of interest aggregation and interest articulation would be channelled increasingly by formal procedures and structures (Almond and Powell 1984: 102).

Before proceeding further the concepts 'formal' and 'informal' merit clarification. ' 'Formal politics' denotes the constitutional (regulated by law or otherwise codified) political structures and decision-making processes

1. For Zambia see Burnell (2001b: 245-247); for Tanzania see Erdmann (2002a: 30).

2. Based on something Lipset and Rokkan left unclear, Randall (2001: 242) even suggested that political cleavages created by the parties, rather than social cleavages, may have much more relevance to the 'third world'. As for party formation in Africa, in most cases I argue that the ethnic cleavage is of major relevance.

3. For a general discussion of the concept see Betz et al. (1999: 217-228); Misztal (2000); for the use of the concept for African politics see Chabal and Daloz (1999: $1-16)$. 
within a political system. The concept relates to the de jure version of politics, how something is supposed to be done. It is the 'official' version of politics. 'Informal politics' concerns those political relationships, behaviour and expectations of individuals and groups that are not structured by fixed written (formal) rules within the same political system. Informal politics can harden into informal structures, which means that they can occur in a regular way alongside the formal structures, but the results are not so predictable. Thus one can even speak of an institutionalized informality. Informal politics denotes the striving of individuals and groups (parties, associations and so on) for material and non-material benefits within the realm of politics, aspiring for influence and power in order to affect the distribution of resources. The implication often is that constitutional norms and regulations are ignored, or at least not observed according to the stipulated rules. ${ }^{1}$

Research on western European countries quite 'naturally' ignored informal aspects of politics. It has been the bureaucratic structures that have been of interest - written statutes and party programmes, constitutional procedures of elections, contractual relations to auxiliary organizations such as trade unions or Christian associations, perhaps the competition of party factions, working groups or 'tendencies', and relations between the party proper and sub-organizations (such as groups for youth and women), the party and its parliamentary groups. However, most scholars have been aware of personal relationships, of old-boy networks, of intrigues and conspiracies in back-rooms, of informal manipulations of conventions. Lack of transparency, oligarchic structures, lack of internal democracy, and the predominance of the leadership are sometimes cited as regretable features of parties. All this points to the conclusion that informal interaction complements, intertwines with or even surmounts formal actions. The former might even gain predominance. But these phenomena have not been studied systematically or as a discrete topic. Analysis of party development in Africa, Asia and Latin America has revealed many more and systematic informal actions, relationships and networks such as clientelism, patronage, neopatrimonialism, personalism, factionalism. ${ }^{2}$ The so-called criminalization of politics is a recent addition to this literature (for Africa see Bayart et al. 1999).

1. This paragraph draws on Erdmann et al. (2004).

2. See for an overview, including North Africa and the Near East, of the more recent literature, Erdmann et al. (2004). 
As regards Africa, since Bienen's and Lemarchand's first conceptual discussion of 'machine politics' based on clientelism and patronage, no systematic attempt has been made to bring together the coexistence of formal and informal elements into the systematic analysis of political parties. ${ }^{1}$ With few exceptions, this applies to party research on other continents as well. ${ }^{2}$ But in Africa especially, where informal institutions, relations and actions appear prominent in most parties, it is essential to include informality in the conceptual framework for the analysis of party politics.

An example may clarify the point. If we look for formal ties/linkages of parties to civil society organizations we could well find that Africa's parties have no real foundation in the respective society. They simply seem to float. But as soon as we search for informal relations we see that these same parties have quite close linkages with society. Not, however, via formal organizations but through clientelism, other kinds of networks, and patronage. Parties without a strong organization but based on ethnic and regional identity or solidarity are able to aggregate and articulate social interests. Of course an ethnic identity once politically mobilized can turn into a danger to the larger political community, and if the distribution of public resources follows strictly regional or ethnic interests then particularistic interests will violate rules of distribution dictated by rational universal principles.

Ignoring informal politics not only results in a descriptive impoverishment but reduces analytical depth as well and thus gives us an inadequate understanding of how political parties in Africa actually operate. In new democracies, such phenomena tend to be viewed as causes for malfunc-

1. Bienen (1971: 195, 200-201), who appears to have been the first to apply the American concept of 'machine politics' to Africa but remained very sceptical about it and thought of it in a heuristical manner only. For him the concept was ill defined and became too wide, almost synonymous with patronage politics. In fact there were major differences between the American and the African situation, one being that based on the federal structure of the US there was a weak central bureaucracy with strong localised party units which allowed for the development of bossism in local politics. In Africa the reverse is true: the party is usually controlled by the centre. For more details see Erdmann (2002a: 7-8); Lemarchand (1972: 68-90); Weingrod (1969: 376-400) was probably one of the first who wrote about clientelism and party politics in western Europe analysing politics in Sardinia.

2. Exceptions: Appleton (1984: 23-54); Levitzky (1998: 77-92); Köllner (1999: 164173). Only recently a more systematic attempt was made to find an appropriate approach to the solution of this problem, see Betz and Köllner (2000: 94-104), and Erdmann et al. (2004); for case studies, see Erdmann (2002a), Köllner (2003: 352-376), and Betz (2003). 
tions, 'deficits' or 'underperformance' of parties, as anomalies of 'normal' functions based on the concept of the western European mass party. The 'underperformance' or functional deficits are then related to the role political parties are supposed to play in democracies or for the process of democratic consolidation. The conclusion is that these deficits do not support the development or consolidation of a democratic regime, and may even be an obstacle to it (Randall and Svåsand 2002b). This, no doubt, can be true. However, here again we encounter the problem with the 'mass party'. Its image is a party with a clear-cut ideology, a programme, a paying mass membership, a bureaucratic organization which reaches or builds up from the grass-roots, democratic participatory structures, close links to ancillary organizations, and a fairly stable electorate. This image or concept of a party is an idealisation based on such parties such as the German Social Democratic Party (SPD). It should be clear that by no means all of western Europe's many parties have displayed these features - let alone the newer parties in new democracies of Eastern Europe and Latin America or the current state of many parties in old democracies, in particular the US. It must be asked how democracy could be developed and even consolidated with parties so different from the SPD, or say its Swedish counterpart or Britain's Labour Party?

From this perspective it would be wrong to equate all noted deficits or all informal politics automatically with functional deficits in terms of democratic development, particularly if this process is not viewed as something that can be achieved within a just couple of years. It has become commonplace to say that formal institutions need some additional ingredients to operate smoothly. Some degree of informality might even be necessary: 'informal politics reveals and bridges shortcomings in the formal system' (Dittmer 2000: 306; Beyme 1991). So it seems obvious that the process and the results of informal politics require more careful analysis and evaluation. It cannot be ignored, for example, that clientelistic networks and patronage provide legitimacy for a party leadership and, depending on the political orientation of the party elite, can even contribute to the stabilization of a democratic regime. The point is that some of the informal institutions or politics may provide a functional equivalent to some of the formal institutions or politics. This is not to argue that a democracy based on parties that operate with clientelistic networks and built on patronage can be consolidated. For a certain period in the process of democratization and consolidation informal policies might be useful, for instance to pull or keep the wider political community together, or to stabilize newly created democrat- 
ic institutions. In the long run, however, there is no doubt that formal institutions need to gain the upper hand in order to consolidate a democracy. This means the rule of law and an effective legal rational state bureaucracy becomes crucial. As has been argued elsewhere, neopatrimonial rule is not an obstacle to democratic transition, but it is an impediment to democratic development and consolidation and is conducive to hybrid regimes such as neopatrimonial multiparty systems (Erdmann 2003: 267-292).

From the above, it should be clear that any approach to political parties in Africa which does not consider informal institutions and informal politics is likely to fail to capture a major dimension of party politics. Instead research on the formal dimension has to be complemented by research that focuses on the dimension of informality (which could well be the major dimension), and should inquire into whether they provide functional equivalents or not. Informal relations such as clientelism, personalism as well as family, clan and ethnic and religious or old-boy networks are crucial for an understanding of Africa's parties. And it should be noted that this is basically not an 'African' problem but applies to Asia and Latin America as well.

\section{An African or a universal typology?}

Is it necessary to create a new type or even a new typology of parties specifically for the African context? Classificatory and comparative typologies do not explain anything, but they help to describe and to systematize the multiplicity of empirical observations and thus to facilitate empirically founded generalizations. With that goes a simplification of a complex reality. Such typologies are meaningful if they allow for problem-orientated discrimination which can guide further research.

As indicated in the introduction, party research has been biased by western European experience. This has been true in particular for party typologies. Even when new or modified typologies were created, their application to Africa has been of little help. The major reason was they were too simplistic and misled by the concept of 'mass party'. ${ }^{1}$ Additionally, there was a fundamental lack of empirical research. These factors contributed to the marginalisation of research on parties in Africa. While this kind of research is still in its infancy, it is tempting to create area specific typologies of parties for the African context as, for example, I have tried to do in

1. For an overview, see Erdmann (2002c: 259-285); for the relevant literature, see footnote 3 on p.34. 
the past by suggesting the concept of a 'neopatrimonial party' (Erdmann 1999: 386-387). Besides some problems related to the use of neopatrimonialism, which tends to become a deus ex machina or a 'catch-all' concept, ${ }^{1}$ there are several reasons why this is not very useful. First, the creation of an area-specific typology again carries the danger of isolation and marginalisation. Secondly, it might support the creation of ad hoc types that do not have lasting relevance. Third, it can end up, in Sartori's words by 'replacing Western centricity with quixotic Western eccentricity, that is, in carrying back home the flaw we had previously exported abroad' (Sartori 1976: 265).

A first post-1989 typology of political parties in Africa has been offered by van de Walle and Smiddy with three 'categories' of parties: 'ex-single parties' (still in power or in opposition after the transition), 'historic [opposition] parties' (banned and dormant during the authoritarian phase), and 'new parties' (founded after the transition) (Van de Walle and Buttler 1999: 19-21). Apparently based on the two criteria of time and access to state resources (state bureaucracy, finance and media) - unfortunately, the authors are not very explicit about their criteria - the typology seems be useful only as an ad hoc type for the first round of multi-party elections after 1989. For during the second or third set of elections the difference between an ex-single party and a new party then in power becomes blurred once the latter gains access to state resources. ${ }^{2}$

Instead of an area-specific attempt like the above, then, a universally applicable typology would be more appropriate. It is only recently that such an ambitious typology has been attempted, by Diamond and Gunther, which provides a framework for parties in Africa (Diamond and Gunther 2001). Their typology is comprised of 15 different types or 'species' of parties each of which belongs to a broader 'genus' of party types. Having 15 types of party does not satisfy the principle of parsimony. On the other hand, it is difficult to reconcile this principle with the necessities of a universal typology appropriate for the historical and regional multiplicity of political parties. It can be expected that for any particular region at a particular mo-

1. For a critical review of the concept, see Erdmann and Engel (2002).

2. It is important to note here that the time factor may, in fact, be crucial to explaining different degrees of institionalization and/or volatility of parties. The difference between 'old' and 'new' parties has already been pointed out by Lipset and Rokkan (1967: 51) for western Europe in the nineteenth century: late-comers have more difficulties to entrench themselves in the electorate, although this is related to competition of mass parties and the time of suffrage extension. 
Table 1: Typology of Party Types

\begin{tabular}{lll}
\hline Parties & \multicolumn{2}{c}{ Subtypes } \\
\hline Elite-based & Pluralistic & Proto-Hegemonic \\
& Clientelistic & \\
Mass-based & & \\
Ideological / Socialist & Class-mass & Leninist \\
Ideological / Nationalist & Pluralist Nationalist & Ultranationalist \\
Religious & Denominational-mass & Religious Fundamentalist \\
Ethnicity-based & Ethnic & \\
& Congress & \\
Electoralist & Catch-all & \\
& Programmatic & \\
& Personalistic & \\
Movement & Left-Libertarian & \\
& Post-Industrial Extreme Right & \\
\hline
\end{tabular}

Source: Diamond and Gunther (2001: 9).

ment in time only a few types of party will be of relevance. But for the sake of international comparability is seems inadvisable to take parsimony as the main guiding principle. However, the problem can be overcome by turning Gunther and Diamond's 'genus' into 'type' and 'species' into 'subtypes'. Then we end up with five types: elite-based, mass-based, ethnicity-based, electoralist, and movement parties. The 15 subtypes are separated according to sub-categories such as 'pluralistic' versus 'proto-hegemonic' or based on the level of commitment to an ideology or programme. The difference between 'pluralistic' and 'proto-hegemonic' parties is that the first one is loyal to the democratic system while the latter is semiloyal or an anti-system party. The result of this exercise is presented in Table 1.

From the African perspective the typology has left out the old state parties which are part of an authoritarian system, and could be termed 'hegemonic parties', ${ }^{1}$ as well as the parties which were related to or based on the anti-colonial independence or liberation movement. It is certainly

1. Bogaards pointed out this shortcoming during the discussion at the AEGIS conference in Hamburg. 
difficult to find a label for them in the suggested typology. But since these parties are not part of a (democratic) multiparty system or are a purely historical phenomenon we can ignore them here for the moment. No doubt this problem needs further consideration.

The typology was based on the following three sets of criteria: (1) the size of the party organization and extent of functions performed, (2) whether a party is pluralistic (tolerant) or proto-hegemonic in its aims and behaviour, (3) differences in programmes or ideologies. With these criteria - organization/structure, political behaviour, and ideology/programme - which cover essential features and functions of a party, the typology is sufficiently complex, because usually one or other of these criteria is used by itself to build other typologies in a rather simplistic dichotomy. The typology thus avoids too early a reduction to a few selective aspects of the parties. For the final classification of actual parties four dimensions were differentiated: (1) goals, (2) electoral strategy, (3) organizational structure, and (4) social basis. ${ }^{1}$ This satisfies the claim to a multidimensional profile of distinctive features (Wiesendahl 1980: 200).

For the African context, the type of the ethnicity based party is of major interest. What was referred to above as 'ethnic' and 'multiethnic party' (in Horowitz's terminology) is in accordance with the 'ethnic party' and the 'ethnic congress party' in the universal typology. The difference between the ethnic and the ethnic congress party rests on the following discriminating dimensions: ${ }^{2}$.

- Goals: both types of party are particularistic. The ethnic party defends or advances ethnic group interests, the ethnic congress defends and advances the interests of the participating ethnic groups, but tends to contain social conflict through the sharing of power and resources among these groups.

- Electoral strategy: the ethnic party mobilizes with appeals to ethnic group benefit and threat, and through clientelism; the ethnic congress gains votes through clientelistic loyalties and exchanges among constituent groups, and through appeals to national integration.

1. For the details see Diamond and Gunther (2001: 10-11).

2. This follows in a modified way the details laid out in Table 2, ibid.; for example, while Diamond and Gunther (2001: 11) subsume 'religious' under the 'ethnicity' label, I believe it should be kept separate, partly because there are two subtypes of religious-based parties. 
- Organizational structures and linkages: the structure of the ethnic party ranges from weak organization based on traditional community ties and loyalties to well-established mass personal organizations with ancillary social and cultural organizations; the structure of the ethnic congress is coalitional or federative based on ethnic or regional elites and local notables.

- Social basis: the ethnic party is based largely on a single ethnic, regional or national group; the congress is a coalition of more or less distinct ethnic and regional groups.

Before discussing the ethnic and ethnic congress any further, an explanation is necessary as to why the concept of the 'clientelistic' and 'elite' party is not applied to the African context. Both terms have been defined in a very specific way which does not fit (most) parties in Africa. The concept of the 'elite party' is usually related to the limited franchise of nineteenth century Europe, and might be applicable to the African parties shortly before independence (no universal suffrage). ${ }^{1}$ The clientelistic party type is again related to political parties of late nineteenth and early twentieth century Europe, Latin and North America. These parties are defined as making 'high investments in organizational structure and have to provide a constant flow of resources to their followers' (Kitschelt 1995: 449). And exactly the high investment in organizational structure is generally missing in Africa.

To avoid any misunderstanding, the implication is not that all parties in Africa fit into one of the two types of ethnic based parties. The intention is only to say these two are the predominant types. The complex universal typology has the advantage that it provides additional types, which helps to avoid the danger of narrowing the analytical perspective to only two types (as was the case for most of the earlier typologies) or ad hoc types derived from just one or a few divergent cases. For example, some of the old state parties, such as the CCM of Tanzania or the Parti Socialiste du Sénégal (PS) might be classified as mass party or rather as an 'electoral party', either 'personalistic' or 'catch-all'; one or the other party in Botswana may belong to that type as well. For the few Islamic parties in Africa, there might be a category as well, the religious based denominational or fundamentalist. Moreover, the universal typology partly based on types that existed during different historical times can accommodate party change as well. For example, when the social basis of an ethnic congress party changes in more

1. See for example Katz and Mair 1995: 18; Beyme 2000: 27-28. 
urban areas and it thereby becomes an electoral party. Finally, there is the perhaps unresolved problem of a 'regional party' type which as yet has no place in this typology. The parties in Malawi might be such a case. ${ }^{1}$ In fact, the three Malawian parties have a quite clear-cut regional basis. However, this can be interpreted as an ethnic coalition as well - a coalition of ethnic groups living next to each other in connected territories. This point of view finds support from the fact that there is apparently no regional identity in Malawi, according to the results of the Afrobarometer. The most prominent identity - apart from Malawian - is ethnic or 'tribal' in the local English (Afrobarometer 2002: 40). A different matter is of course those parties that demand a separate state or regional autonomy based on an ethnic identity with its claim of its own history, culture and/or language. This is definitely not the case in Malawi.

A further important advantage of Gunther and Diamond's typology is that the various types are linked to seven party functions, which can be reduced to four as indicated above. These functions are (a) candidate nomination, (b) electoral mobilization, (c) issue structuring, (d) societal representation, (e) interest aggregation, (f) forming and sustaining government, (g) social integration, to which should be added 'forming opposition and proposing alternatives'. These functions provide an additional tool for a differential analysis of the various party types. The implication is of course not that all party types perform the same functions in the same way, but rather to the contrary.

It seems obvious that the proposed universal typology is not a perfect one. It requires close scrutiny for logical consistency and applicability. But still, it is the first attempt to overcome in a coherent manner the established bias in this field of research. It is true that it is more than a little based on western European types, though also comprises types which are not derived from Europe. There is a reasonable explanation for this. Western Europe provides not only the longest history of parties, and therefore perhaps of their diversity, but also the longest history of research, which is strongly dependent on the freedom to do research. The extension of research to other areas, and applying the universal typology to new empirical evidence from outside Europe will help refine and diversify the typology. Other approaches and typologies may be void of Eurocentricity, but usually not of all forms of 'centricity'.

1. Patrick Molutsi of IDEA (Stockholm) pointed out this problem. 


\section{Conclusion}

This article argues that although there is a strong western European bias in the established party research it can be applied in a modified way to political parties in Africa as well. The conventional functional approach provides an appropriate tool for analyzing the operations of parties. But it needs to be opened up for questions which address possible other or additional functions, such as providing patronage, which are not so familiar from the European context, and other modes through which classical functions can be performed as well.

The cleavage approach which searches for the social structuring of party formation and party conflict can be helpful if freed from its sequential conceptualization and used in a heuristic way. The predominant structuring cleavage for African parties is identified as being ethnicity, at least for the time being. The upshot is not that each ethnic group forms its own ethnic party, but the multiplicity of ethnic groups and the different evolution of ethnic identities necessitates all sorts of ethnic coalition building towards multiethnic parties as the most regular feature of party formation. In addition, the approach offers other possible cleavages which might arise over time.

While party research has concentrated on formal institutions and formal politics, a crucial modification is necessary in order to be able to capture party politics in Africa. This means including informal institutions and politics such as the operation of clientelism, other kinds of networks, and patronage. In this context and related to the functional approach it is necessary to consider functional equivalents to those elements of party behaviour that contribute to democratization, to stabilizing democracy, even if only temporarily, and, perhaps to the consolidation of the party system as a contribution to the consolidation of democracy.

Finally, a universal typology of parties that includes the differentiated experience of western Europe but is enlarged by non-European types provides a basic tool for party research in Africa. A universal typology is preferred to an area specific African typology because it avoids the danger of marginalisation of research on parties in Africa, as has happened in the past, and it provides a number of types which allow for a differentiated classification of established parties as well as for new features of parties. Of course all the suggested modifications have now to be tested and discussed in detail if they are to provide useful insights into party politics in Africa. 


\section{Acknowledgements}

A first version of this article was prepared for the thematic conference of the Africa-Europe Group for Interdisciplinary Studies (AEGIS) 'How People Elect Their Leaders, Parties, Party System and Elections in Africa (SS)', Institute of Africa Affairs, Hamburg, 22-23 May 2003. The author also appreciated the very useful comments of the anonymous reviewer in the journal Democratization. For many insights into the problems of party research the author thanks colleagues, in particular Patrick Köllner of the Institute of Asian affairs, for the discussions within the Interregional Research Group 'Political parties between formal and informal politics' of the German Institute of Global and Area Studies.

\section{References}

Afrobarometer Network (2002), Afrobarometer Round I: A Compendium of Comparative Data from a Twelve-Nation Survey. Afrobarometer Working Papers, No. 11; www.afrobarometer.org.

Almond, G.A. and B. Powell (eds) (1984), Comparative Politics Today. A World View. Boston: Little, Brown.

Appleton, A. (1984), 'The Formal versus Informal Rules of French Political Parties', in Lawson, K. (ed.) How Parties Work. Perspectives from Within. Westport: Praeger, pp. 23-54.

Bartolino, S. and P. Mair (2001), 'Challenges to Contemporary Political Parties', in Diamond L. and R. Gunther (eds) Political Parties and Democracy. London: John Hopkins University Press, pp. 327-344.

Basedau, M. (2002), 'Zum Zusammenhang von Wahlsystem, Parteiensystem und Demokratie-stabilität in Afrika. Kritische Anmerkungen zum Potenzial von Electoral Engineering', Africa Spectrum 37: 3, pp. 311-333.

Bayart, J.-F. et al. (1999), The Criminalization of the State in Africa. London: James Currey.

Betz, J. (2003), Die gesellschaftliche Anbindung der indischen Parteien. Deutsches Übersee-Institut, Arbeitspapiere der Forschungsgruppen. Hamburg: Deutsches Übersee-Institut.

Betz J., P. Köllner and H. Mattes (1999), 'Informelle Politik im internationalen Vergleich', Nord-Süd aktuell 13: 2, pp. 217-228.

Betz J. and P. Köllner (2000), 'Informale Politik im internationalen Vergleich: Ein Forschungsaufriss', Nord-Süd aktuell 15: 1, pp. 94-104.

Beyme, K. v. (1982), Parteien in Westlihen Democratien. München: Beck.

Beyme, K. v. (1991), Regieren in der Bundesrepublik. Formale und informale Komponenten des Regierens. Opladen: Leske \& Budrich.

Beyme, K. v. (2000), Parteien im Wandel. Wiesbaden: Westdeutscher Verlag. 
Bienen, H. (1967), 'The Ruling Party in the African One-Party State: TANU in Tanzania', Journal of Commonwealth Political Studies 5, pp. 214-230.

Bienen, H. (1971), 'Political Parties and Political Machines in Africa', in Lofchie, M. (ed.) The State of the Nations: Constraints on Development in Independent Africa. Berkeley: University of California Press, pp. 195-214.

Bogaards, M. (2000), 'Crafting Competitive Party Systems: Electoral Laws and the Opposition in Africa', Democratization 7: 4, pp. 164-166.

Bogaards, M. (2004), 'Counting Parties and Identifying (Dominant) Party Systems in Africa', European Journal of Political Research 43: 2, pp. 173-197.

Bratton, M. and D.N. Posner (1999), 'A First Look at Second Elections in Africa, with Illustrations from Zambia', in Joseph, R. (ed.) State, Conflict, and Democracy in Africa. Boulder: Lynne Rienner Publishers, pp. 382-391.

Burnell, P. (2001a), 'Financial Indiscipline in Zambia's Third Republic: The Role of Parliamentary Scrutiny, Journal of Legislative Studies 7: 3, pp. 34-64.

Burnell, P. (2001b), 'The Party System and Party Politica in Zambia: Continuities Past, Present and Future', African Affairs 100, pp. 239-263.

Betz (2001b), 'The Party System and Party Politics in Zambia: Continuities Past, Present and Future', African Affairs 100: pp. 239-263.

Chabal, P. and J.-P. Daloz (1999), Africa Works: Disorder as a Political Instrument. London: James Currey, pp. 1-16.

Chaligha, A. and M. Mmuya (1994), Political Parties and Democracy in Tanzania. Dar es Salaam: Friedrich Ebert Foundation.

Coleman, J.S. and C.G. Rosberg (eds), (1964), Political Parties and National Integration in Tropical Africa. Berkeley: University of California Press.

Dalton, R.J. and M.P. Wattenberg (2002), 'Unthinkable Democracy: Political Change in Advanced Industrial Democracies', in Dalton, R.J. and M.P. Wattenberg (eds) Parties without Partisans. Political Change in Advanced Industrial Democracies. Oxford: University Press, pp. 3-16.

Diamond, L. and R. Gunther (2001), 'Types and Functions of Parties', in Diamond, L. and R. Gunther (eds) Political Parties and Democracy. London: John Hopkins University Press, pp. 3-39.

Dittmer, L. (2000), 'East Asian Informal Politics in Comparative Perspective', in Dittmer, L. et al. (eds) Informal politics in East Asia. Cambridge: University Press, pp. 290-308.

Eith, U. and G. Mielke (eds) (2000), Gesellschaftliche Konflikte und Parteiensysteme. Opladen: Westdeutscher Verlag.

Elwert, G. and R.M. Segbenou (1983), 'Urbanisation sans bidonvilles: Le role des structures économiques décentralisées pour le dévelopment urbain de Cotonou', (R. P. du Benin), Journal des Africanistes 53: 1-2, pp. 119-143.

Emerson, R. (1966), 'Parties and National Integration in Africa', in LaPalombara, J. and M. Weiner (eds) Political Parties and Political Development. Princeton: Princeton University Press, pp. 267-301. 
Emminghaus, C. (2002), 'Politische Parteien und ihre Funktionen in afrikanischen Demokratien. Analysekonzept und empirische Befunde zu Botswana und Namibia', Afrika Spectrum 37: 3, pp. 287-309.

Epstein, A.L. (1958), Politics in an Urban Community. Manchester: Manchester University Press.

Erdmann, G. (1999), 'Parteien in Afrika. Versuch eines Neuanfangs in der Parteienforschung', Afrika Spectrum 34: 3, pp. 375-398.

Erdmann, G. (2002a), Tanzania: Informelle und formelle gesellschaftliche Verankerung politischer Parteien in Afrika. Deutsches Übersee-Institut, Arbeitspapiere der Forschungsgruppen, Forschungsgruppe 'Parteien im Spannungsfeld formaler und informeller Politik'. Hamburg: Deutsches Übersee-Institut.

Erdmann, G. (2002b), 'Neopatrimoniale Herrschaft - oder: Warum es in Afrika so viele Hybridregime gibt', in Bendel P. et al. (eds) Hybride Regime. Zur Konzeption und Empirie demokratischer Grauzonen. Opladen: Leske \& Budrich, pp. 323-342.

Erdmann, G. (2002c), 'Zur Typologie politischer Parteien in Afrika', Afrika Spectrum 37: 3, pp. 259-285.

Erdmann, G. (2003), 'Apokalyptische Staatlichkeit: Staatsversagen, Staatverfall und Staatszerfall in Afrika', in Bendel, P. et al. (eds) Demokratie und Staatlichkeit. Systemwechsel zwischen Staatsreform und Staatskollaps. Opladen: Leske und Budrich, pp. 267-292.

Erdmann, G., J. Betz and P. Köllner (2004), 'Die gesellschaftliche Verankerung politischer Parteien in nicht-westlichen Demokratien als Forschungsproblem', in Betz, J. et al. (eds) Parteien und ihre gesellschaftliche Verankerung in Entwicklungsländern. Wiesbaden: Westdeutscher Verlag, pp. 7-33.

Erdmann, G. and U. Engel (2002), 'Neopatrimonialism Reconsidered - Critical review and elaboration of an elusive concept'. Paper presented to the 45th annual meeting of the African Studies Association, Washington DC, December 4-8 (published as Neopatrimonialism Revisited-Beyond a Catch-all Concept. DÜI Working Paper Global and Area Studies. Hamburg: Deutsches Übersee Institut, 2006).

Erdmann, G. and H. Weiland (2000), 'Gesellschaftliche Konfliktlinien, Ethnizität und Parteienformation in Afrika', in Eith, U. and G. Mielke (eds) Gesellschaftliche Konflikte und Parteiensysteme. Opladen: Westdeutscher Verlag, pp. 246-262.

Fondation Friedrich Ebert (1995), Le programme des parties politiques au Benin. Colloque national tenu à l'hotel PLM Alédjo, 10 Mars 1994, Cotonou-Benin. Cotonou: Nouvelle Presse.

Gluckman, M. (1960), 'Tribalism in Modern British Africa', Cahier d'Études Africaines 1, pp. $55-70$.

Henning, K.M. (1998), Die Rolle der Parteien in der Konsolidierung der Demokratie in Tanzania - die Opposition behindert sich selbst. Magisterarbeit, Philosophische Fakultät der Universität Freiburg.

Hodgkin, T. (1961), African Political Parties. London: Penguin Books.

Horowitz, D.L. (1985), Ethnic Groups in Conflict. Berkeley: University of California Press. 
Kadzamira, Z.D. et al. (1998), Profiles and views of political parties in Malawi. Final report and recommendations, Department of Political and Administrative Studies, Chancellor College, University of Malawi, Zomba.

Katz, R.S. and P. Mair (1995), 'Changing Models of Party Organisation and Party Democracy. The Emergence of the Cartel Party', Party Politics 1: 1, pp. 5-28.

Kitschelt, H. (1995), 'Formation of Party Cleavages in Post-Communist Democracies. Theoretical Propositions', Party Politics 1: 4, pp. 447-472.

Köllner, P. (1999), 'Informelle Elemente in der japanischen Politik. Teil 2: Persönliche Unterstützungsvereinigungen und Erbabgeordnete', Japan aktuell 2, pp. 164-173.

Köllner, P. (2003), 'Die Institutionalisierung politischer Parteien in Südkorea', Verfassung und Recht in Übersee 36: 3, pp. 352-376.

LaPalombara, J. and M. Weiner, M. (1966), 'The Origin and Development of Political Parties', in LaPalombara, J. and M. Weiner (eds) Political Parties and Political Development. Princeton: Princeton University Press, pp. 3-42.

Lemarchand, R. (1972), 'Political Clientelism and Ethnicity in Tropical Africa: Competing Solidarities in Nation-Building', American Political Science Review 66: 1, pp. 68-90.

Lentz, C. (1994), 'Tribalismus' und Ethnizität in Afrika: Ein Forschungsüberblick. Berlin: Das Arabische Buch.

Lentz, C. and P. Nugent (2000), 'Ethnicity in Ghana: A Comparative Perspective', in Lentz, C. and P. Nugent (eds) Ethnicity in Ghana. London: Macmillan Press, pp. 2-6.

Levitzky, S. (1998), 'Instrumentalization and Peronism. The Concept, the Case and the Case for Unpacking the Concept', Party Politics 4: 1, pp. 77-92.

Lipset, S.M. and S. Rokkan (1967) 'Cleavage Structures, Party Systems, and Voter Alignments', in Lipset, S.M. and S. Rokkan (eds) Party Systems and Voter Alignments. Cross-National Perspectives. New York: Free Press, pp. 1-64.

Lonsdale, J. (1992), 'The Moral Economy of Mau Mau: Wealth, Poverty \& Civic Virtue in Kikuyu Political Thought', in Berman, B. and J. Lonsdale (eds) Unhappy Valley. Conflict in Kenya \& Africa. Book Two: Violence \& Ethnicity. London: James Currey, pp. 466-467.

Mair, P. (1994), 'Party Organizations: From Civil Society to the State', in Katz, R.S. and P. Mair (eds) How Parties Organize. Change and Adaption in Party Organizations in Western Democracies. London: Sage, pp. 1-22.

Mair, P. (1997), Party System Change. Approaches and Interpretations. Oxford: Oxford University Press.

Merkel, W. (1997), 'Parteien und Parteiensysteme im Transformationsprozess: Ein interregionaler Vergleich' in Merkel, W. and E. Sandschneider (eds) Parteien im Transformationsprozess. Systemwechsel 3. Opladen: Leske und Budrich, pp. 337-371.

Misztal, B.A. (2000), Informality. Social Theory and Contemporary Practice. London and New York: Routledge. 
Mmuya, M. (1998), Political Reform in Eclipse. Crisis and Cleavages in Political Parties. Dar es Salaam: Friedrich Ebert Foundation.

Moegenburg, I. (2002), Die Parteienlandschaft im Senegal - Tragfähige Grundlage der Demokratisierung? Marburg: Phil. Diss.

Morgenthau, R.S. (1964), Political Parties in French-Speaking West Africa. Oxford: Clarendon Press.

Mozaffar, S. (1995), 'The Institutional Logic of Ethnic Politics: A Prolegomenon', in Glickman, H. (ed.) Ethnic Conflict and Democratization in Africa. Atlanta: African Studies Association Press, pp. 33-69.

Nuscheler, F. and K. Ziemer (1978) 'Politische Organisation und Repräsentation in Afrika', 1. u. 2. Halbband, in Sternberger, D. et al. (eds) Die Wahl der Parlamente und anderer Staatsorgane. Ein Handbuch, Vol. 2, Afrika. Berlin: Walter Gruyter, pp. 126-178.

Panebianco, A. (1988), Political Parties, Organization and Power. Cambridge: University Press.

Randall, V. (2001), 'Party Systems and Voter Alignments in the New Democracies of the Third World', in Karvonenn, L. and S. Kuhnle (eds) Party Systems and Voter Alignments Revisited. London: Routledge, pp. 238-260.

Randall, V. and L. Svåsand, (2002a), 'Political Parties and Democratic Consolidation in Africa', Democratization 9: 3, pp. 30-52.

Randall, V. and L. Svåsand, (2002b), 'Introduction: The Contribution of Parties to Democracy and Democratic Consolidation', Democratization 9: 3, pp. 1-10.

Salih, M.M.E. (ed.) (2003), African Political Parties. London: Pluto Press.

Sartori, G. (1976), Parties and Party Systems. A Framework for Analysis. Cambridge: Cambridge University Press.

Schmidt, S. (1996), 'Zur Rolle der politischen Parteien in afrikanischen Demokratisierungsprozessen', Konrad-Adenauer-Stiftung Auslandsinformationen 6, pp. 53-54.

Schmidt, S. (1997), 'Parteien und demokratische Konsolidierung in Afrika unter besonderer Berücksichtigung der Entwicklung Kenias', in Merkel, W. and Sandschneider, E. (eds) Parteien im Transformationsprozess. Systemwechsel 3. Opladen: Leske und Budrich, pp. 251-292.

Schmitter, P. (2001), 'Parties Are Not What They Once Were', in Diamond, L. and R. Gunther (eds) Political Parties and Democracy. Baltimore: John Hopkins University Press, pp. 67-89.

Tordoff, W. (1984), Government and Politics in Africa. Bloomington: Indiana University Press.

Van de Walle, N. and K.S. Buttler (1999), 'Political Parties and Party Systems in Africa's Illiberal Democracies', Cambridge Review of International Affairs 8: 1, pp. 14-28.

Wallerstein, I. (1966), 'The Decline of the Party in Single-Party African States', in LaPalombara, J. and M. Weiner (eds) Political Parties and Political Development. Princeton: Princeton University Press, pp. 201-214.

Wanjohi, N.G. (1997), Political parties in Kenya. Nairobi: Views Media. 
Ware, A. (1996), Political Parties and Party Systems. Oxford: University Press.

Weber, M. (1978 [1968 repr.]), Economy and Society. An Outline of Interpretative Sociology, ed. by G. Roth and C. Wittich, New York: Bedminster Press.

Weber, M. (1980), Wirtschaft und Gesellschaft. Grundriss der verstehenden Soziologie. Tübingen: Mohr.

Weingrod, A. (1969), 'Patrons, Patronage, and Political Parties', Comparative Studies in Society and History 10, pp. 376-400.

Widner, J.A. (1997), 'Political Parties and Civil Societies in Sub-Saharan Africa', in Ottaway, M. (ed.), Democracy in Africa. The Hard Road Ahead. Boulder: Lynne Rienner, pp. 65-82.

Wiesendahl, E. (1980), Parteien und Demokratie. Eine soziologische Analyse paradigmatischer Ansätze der Parteienforschung. Opladen: Leske und Budrich.

Young, C. (1976), The Politics of Cultural Pluralism. Madison: University of Wisconsin Press. 


\title{
Political Parties in Africa: Different, Functional and Dynamic? Reflections on Gero Erdmann's 'Party Research: The West European Bias and the "African Labyrinth"
}

\author{
Peter Burnell
}

Political parties have a long and chequered history in Africa, with no less than 143 parties being established there between 1945 and the end of the first wave of decolonization in 1968, increasing to 153 by the mid-1970s (Mozaffar 2005: 395). Against this background Gero Erdmann's 'Party Research: The Western European Bias and the "African Labyrinth" is both very timely and thought provoking, and as such his chapter in this book merits a considered response. The few brief reflections on it that are offered here attempt to explore further some of the propositions it contains and, more boldly, suggest how the insights it provides constitute a platform for launching new directions in research into the role of parties in African politics - past, present and future.

The premise to Gero Erdmann's account of course is the seeming lack of interest shown by much of the recent political science party politics literature in party systems in Africa and, more specifically, Africa's political parties. ${ }^{1}$ And it is certainly true that, after the early years of independence were followed by a drift not just towards de jure one-party states but personal autocracies and military-bureaucratic rule, the larger political science literature on parties tended to overlook Africa, unlike the research agenda of Africanists. A content analysis of the first ten years of the highly esteemed journal Party Politics, edited jointly from the UK and US, for instance reveals that compared with around 250 articles on Western Europe, North America, Japan, Israel, Australasia and, increasingly, several postcommunist countries or theoretical articles attuned to all these countries,

1. Honourable exceptions include Bogaards 2000: 163-190); Randall and Svåsand (2002: 30-52). Of course there are Africanists who have written extensively on party politics in Africa, N. van de Walle for example; and M. Salih's excellent edited book African Political Parties: Evolution, institutionalism and governance (London: Pluto Press, 2003) includes chapters by scholars who would not necessarily describe themselves as Africa specialists. 
the number on parties in Latin America and Asia combined stood at not more than twenty-five and only a further seven could be said to be on Africa. Of those seven, one which on the surface looks particularly promising because of its comparative nature - 'Party institutionalisation in 30 African countries' (Kuenzi and Lambright 2001: 437-468) - draws most of its source materials from the non-Africa literature. And of the minority of source materials it does cite on Africa, the majority predate the 1990s, that is before the so-called second liberation that reintroduced political pluralism to many African countries. Clearly the editors of Party Politics themselves came to the conclusion that Africa was seriously underrepresented, for in 2005 the fourth issue of Volume 11 was a specially commissioned issue containing five substantive new articles on aspects of parties and party systems in African countries. On the book front, neither of two substantial and important contributions to the literature on parties in recent years - Political Parties and Democracy and Political Parties: Old Concepts, New Challenges - contain chapters on Africa although they include material on just about everywhere else (Diamond and Gunther 2001; Gunther, Montero and Linz 2002).

The reasons that lie behind the political scientists' relative neglect of Africa's parties in the last decade or so provide an interesting topic for discussion in its own right. But one of them, which underpins the significance of Gero Erdmann's welcome attempt at correcting the situation, is of course the long held assumption that Africa's parties are simply different, they are not like parties as we know them in the established liberal democracies; in fact, they may not even really be parties at all. Indeed, the worth of lending support to political parties in Africa as a means whereby international actors can help promote democratization there has been questioned for precisely this reason (Cranenburgh 1999: 104). ${ }^{1}$ Investigated far too little by party specialists, the attempt to get to grips with the claim that Africa's parties are peculiar, by identifying the precise nature of the difference, is a first step: it now obliges us to think further about the patterned relationships among the distinguishing characteristics that he identifies. This in turn should lead to a much bigger, and exciting challenge: what, if any, causal-type connections exist between on the one side those characteristics, which define how a party functions, and on the other side the functions they

1. Cranenburgh emphasised the personalistic and clientelistic nature of Africa's political parties and could not envisage them being suitable agents of democracy. Political party aid is currently a very topical and contested issue for organisations like Germany's political foundations. 
do or do not perform, perform well or perform badly, for the wider polity - that is, functionalism understood in a larger structural-functionalist setting. The use of the term 'causal-type' here is quite deliberate, for we are all well aware of how contentious and suspect is the idea of establishing causal relations in social science in general, and politics specifically.

In effect, then, Erdmann's chapter presents us with a nest of related issues: the distinctiveness of Africa's parties; whether parties in Africa serve equally well certain broad political purposes similar to those that are allegedly promoted elsewhere, in Western Europe for instance; and what is the relationship between the characteristics of Africa's parties and their functional effectiveness in that wider sense - that is, how does the former affect the latter? And to these issues we might add the question does it even matter if Africa's parties do not serve all the same purposes that we associate with them in the literature on parties in Europe? After all, a different combination of functional priorities, or at minimum a different rank order among such functions, one that is specifically African, might offer a more appropriate analytical lens.

Some reflections arising from these issues are summarised under seven short headings below. First, on the characteristics displayed by African political parties; second, on the separateness of Africa's experience with political parties; third, problematising the functional performance of parties; fourth, asking why - or why should - we study Africa's parties; fifth, nominating the 'core' functions of parties; sixth, on the significance of informal politics; and seventh, the importance of ethnicity and the multitude of questions surrounding ethnicity in African politics. These are advanced as suggestions for ways in which research on navigating the African labyrinth can, with the benefit of Erdmann's chapter, be taken further forward.

\section{'Characteristics'}

Gero Erdmann reminds us of ten characteristic features of political parties in Africa as they are discussed in the wider literature and confirmed by his own research in several African countries. Such a compilation looks more than enough if we now want to inquire into the ways certain typical features tend to beget other features, or how particular clusters of characteristics arise from the same set of predisposing conditions. However there is a further characteristic that we might think about adding to the ten that he identifies, on the grounds that it applies to many if not the majority of Africa's parties, namely that they appear only 'semi-loyal' in the de- 
mocratization jargon (a few, like Algeria's Front Islamique du Salut - FIS, have even been accused of being 'anti-system'). ${ }^{1}$ That is to say, the parties might well accept that elections are 'the only game in town', but how they play the game, and attitudes towards the 'free and fair' rulebook and the autonomy of the referee, are sometimes at variance with the western ideal. Hence for instance the violence that sometimes surrounds elections before, during and after the actual election campaign (see Liisa Laakso's 'Electoral violence, past and present', in this collection). More pervasive still are the many different and dubious non-violent stratagems parties employ even prior to the election campaign to make the playing field uneven. Zambia's tripartite elections in December 2001 provide a good example (Burnell 2002b; Elklit 1999). At minimum many parties behave as if they anticipate their competitors are willing to flout the rules of the game, especially where the competitors are in power and seem determined to remain in power. So there are not just governing parties abusing public office to their particular advantage but also opposition parties threatening to boycott an election as a tactic to delegitimate the outcome, even when the true reason might be they fear they lack popular support. Legal or political (and sometimes violent) challenges by the losers to an election result are of course commonplace, as in Zambia following December 2001 and Nigeria's presidential election, May 2003.

Of course all this reflects the fact that many of Africa's newly redemocratising countries themselves really qualify only for the label 'democracy with adjectives' - partial democracy, limited democracy, semi-democracy, 'low-intensity' democracy, ersatz democracy, and so on. And in the most doubtful cases of all they might be better called one or other form of 'competitive authoritarianism' (Collier and Levitsky 1997; Levitsky and Way 2002).

\section{Africa and 'the rest'}

That said, clearly for all the differences we can identify between Africa's parties collectively and parties elsewhere the contrast should not blind us to the larger reality among all the world's supposed democracies or democratically-oriented polities. There is no simple dichotomy or dualism of 'Africa and the rest' - of established western liberal democracies on the one side

1. An anti-system party either rejects the electoral process or, if it were to take office as a result of winning an election it would then abolish elections or remove the possibility of effective contestation in some other way. 
and Africa with its parties on the other. In the current age political parties or more particularly multi-partyism are by no means new to Africa; whereas they definitely are new - or still alien - to some of the prospective and emerging democracies outside of Africa, in Central Asia for example. In terms of their party politics, both Africa and the rest are internally diverse categories. This is even more so if the 'rest' is taken to include not only Japan and southern European states but also newer democracies in Central/Eastern Europe and countries with a considerable heritage of parties and elections in Latin America. And in respect of their party politics, both Africa and the rest have undergone change over time, and are still changing today. And it is the business of change (and the absence of change) that particularly fascinates political scientists. So that invites the obvious question to be posed with respect to any new analytical contribution like Gero Erdmann's - will it help us to make sense of change (or its absence), and even better, will it enable us to predict change and have some feel for its consequences? More on the prospects for change in respect of Africa's parties later. But in the meantime we cannot presume that the relevance of any given set of concepts, models, theories or typologies will always remain the same, or indeed that the same concepts and so forth will be equally useful for all of the countries of Africa ... or, equally useful for examining all the democracies outside Africa.

'The Western European Bias and the "African Labyrinth"' sets out to further the research on African parties. That must mean an aspiration to introduce new research agendas or to enable existing themes to be explored more fruitfully, or both; and in this case there is a clear commitment to do so by remaining within the sub-discipline of party politics as a field of study. That venture is bold, but is surely the right approach. The alternative to believing in the merits of cross-cultural research, namely to construct a standalone framework for Africa's parties, would not just limit the amount of attention given to Africa's parties but also would probably ensure that only Africanists took the trouble to do so. That would be a bad thing. Research on Africa specifically, and on comparative party politics and in political science more generally, would all be the losers. Although made before many of today's states were to gain their constitutional independence, Rustow's observation that geographical proximity is not necessarily the best basis of comparison bears repetition in this context. He said 'Comparability is a quality that is not inherent in any given set of objects; rather it is a quality imparted to them by the observer's perspective' (Rustow 1968: 47). 


\section{Functionalism}

Inquiries into the matter of functions, functionality or functional effectiveness normally begin by asking 'functional for what?' Even before posing that question we would want clarify whether the subject comprises Africa's parties - and if so all parties or just some parties - or the party systems, which by definition refer to not just the number of ('effective') parties (for example a highly fragmented system) but some properties concerning relations between the parties and their differences, for instance whether highly polarised or not. Then there is the task of identifying the various possible objects and making an appropriate selection. Here it is worth distinguishing between the totality of political functions - functions for the political system as a whole, or, perhaps, for political development understood in some holistic sense. 'At its best', Hagopian says, political development as a field of inquiry 'will study questions that other subfields would eschew, in an encompassing political context that other subfields might judge overly ambitious. The new and renewed roles of states in development, the resurgence of ethnic identities and conflict and the challenges they pose to the integrity of nations, and the establishment of new democratic political institutions' all demand attention. Hagopian adds, 'I endorse an approach that leaves open and subject to inquiry the independent influences on political development and that disaggregates the component parts', namely the 'rise and fall of regimes, the establishment and decay of the most important institutions of a political system, the connections between the political and social order, and the role of states in development' (Hagopian 2000: 883).

It remains true that at least some of Africa's parties could in principle perform many functions. After all, this is what the literature on Africa's parties in the early years of independence said was the case. At minimum many of them face a quadruple challenge: to institutionalise the party and institutionalise a party system, to contribute both to the construction of a strong and capable state and to a more secure sense of national identity or nationhood. We could choose to add or separate out a subcategory that dwells on the contribution parties make in and for liberal democracy, or in and for electoral democracy where that seems a more accurate descriptor of a new democracy (Diamond 1996). And we should distinguish from that the matter of how functional the parties are for certain distinctive processes of political change. The functions that parties do perform in stable democracies will not necessarily exhaust or coincide with the functions that parties (and party systems) perform - or ideally should perform - for democratization, that is movement towards bringing about stable democracy. In the case 
of democratization this can mean comparing the functional effectiveness for distinct phases or stages or aspects such as democratic transition, democratic consolidation, post-consolidation, democratic deepening, and so on. In doing so we should not prejudge by forgetting the other side of the coin - dysfunctionality, or how parties possibly undermine democracy, retard consolidation, reverse a transition to democracy, or erode political development understood in some broader sense, and so on. 'Democratic transition', 'democratic consolidation' and so forth are themselves contested concepts and protean in meaning. They imply a stages-based conceptualisation. But there are other ways of looking at democratization such as the one that sees it as multifaceted and multidimensional, a form of 'variable geometry' instead of a clearly identifiable and linear sequence. This makes answering the question 'functional for what?' a bit more complex (Burnell 1998). But none of these refinements fundamentally alters the fact that even within democratization we can choose among different points of reference for the purpose of closer examination.

One thing is clear, we should organise both our list of party characteristics and our list of functions according to what we believe is most vital to which particular object or end. I suspect that different analysts might arrive at different rank orders depending on what object they choose to prioritise. Thus for instance some functions will be more important than others for democratic transition; different functions may be most important for political stabilisation, and yet other functions might be more central to the object of building state capacity or governmental effectiveness.

\section{Sense of purpose: Why study Africa's parties?}

The ground-clearing, once completed, frames the rest of the investigation, enabling us to flag up what we think are the really interesting issues in an African context. These are questions that might well not be the same questions that currently preoccupy party analysts studying the established European democracies, where the major themes include the decline of the mass party form of organisation and political parties' monopoly on interest aggregation, reducing turnouts in general elections and increasing voter volatility, and especially an erosion of trust in the politicians' integrity or commitment to principle, and so on. All these trends are said to be occurring in the longer established democracies but within an expectation that democracy there is secure, and neither political stability nor social peace will be threatened by these developments. Indeed, in some accounts 
such symptoms are even portrayed as evidence of the good health of these democracies. In Africa, however, these same themes would seem to presuppose a golden age of mass party organisation, interest aggregation, political trust that never existed and may never happen. Moreover, genuine doubts about democracy's progress, its survival even, persist in parts of Africa. Former liberation movements as political parties give grounds for being gloomy about democracy's prospect in Namibia for instance.

So although we do need to define concepts appropriately in order to phrase hypotheses, and we must have typologies in order to organise a mass of empirical data, we can really only do these 'first things first' once we already have a sense - albeit not necessarily a very clear or sharp sense - of what it is about African politics we want to understand better, and why. This is an old 'chicken and egg' problem. And political scientists studying Europe, political scientists interested in Africa, other scholars of African affairs, Africans and non-Africans will all have their own ideas about the direction this should take, about what is really important. Put differently, if African parties really are different, and we now know how to characterise the main contours of difference, does it matter? Why does it matter? Is our interest in the parties primarily to view them as explanans or as explanan$d u m$ ? Clarification of the sense of purpose necessarily has implications for the future direction of the research.

Are we most interested in the reasons that help us to understand and make sense of the exceptional characteristics of Africa's parties? If it is the parties that are the dependent variable, then we might have to look at among other things the international dimension, the external political economy constraints, which feature strongly in some accounts of why Africa seems to have so many non-programmatic, personalist and ethnically-based parties. I refer of course to Mkandawire's notion of 'choiceless democracies' (Mkandawire 1999: 133). Neither Africa's parties nor the party systems of African countries individually should be considered as closed systems for another reason: the links that exist between parties in different countries, such as the old ruling parties in southern Africa's former 'front line states'. Relations between the African National Congress in South Africa and Zambia's United National Independence Party for instance would make a fascinating micro-research project. There have been examples of financial support from a ruling party in one country to parties of a similar ethnic or religious hue or with a contiguous regional base across the country's border. At the same time, in contrast to most European parties (and parties in Latin America too), there is an absence of close connections to the main 
international federations of parties based in the West - this being both symptomatic and constitutive of African parties' 'difference'. For belonging to such federations and, in the case of Central and Eastern European parties, their close links with well established parties already inside the European Union, provide channels of socialisation into European models of party organisation, attitudinal and behavioural conventions, and even programmatic or policy-oriented norms. This is not to ignore the existence of networks like for instance the African Christian Democrats Union or the Dakar-based Democrat Union of Africa/African Dialogue Group, but these are fragile organisations, greatly under-resourced (Salih 2005).

Or are we mainly interested instead in how the distinctive nature of African parties helps us to understand better some features of the bigger picture, as the functionalist language would seem to suggest. If, then, parties are treated as the independent variable, then one possible node of investigation lies in the links between parties or party behaviour and various aspects of democratic political change; another node is the links with political stability, conflict prevention and social peace; the functional contribution to a strong state and effective governance offers yet a third node together with the policy content and policy competence the parties bring to government. The connections between any two or more of these nodes suggests yet a further, if even more complex, research agenda. Identifying which of these interests us most is a fairly simple exercise; specifying which ones should interest us most is a normative issue where some sharp disagreements can be anticipated, and Africans and non-Africans might be expected to line up on different sides.

\section{The core functions of parties}

Having decided what intrigues us most, then for taking the analysis further forward we are obliged to make some selection out of the totality of party functions, if only to keep the research design manageable. But to privilege just four 'core functions' as Erdmann's chapter appears to do could be rather too parsimonious - quite apart from the point that not all established parties in the West perform these four functions well, and in some instances certain non-party organisations in the West seem to perform them rather more effectively. Our guide for choosing the functions clearly should be Africa, and not what happens to attract the most agreement in the party literature on European democracies. The function of social or national integration (if for the sake of argument we assume these are one 
and the same thing) could usefully be added to the fourfold list highlighted by Gero Erdmann. Integration is as much a values-based phenomenon as an interests-based phenomenon. It is neither synonymous with nor a mere sub-category of interest aggregation; and there are more dimensions to it than gender issues and the integration of women (considered in the context of Vicky Randall's account of 'Political parties in Africa and the representation of social groups', in this collection). And although integration might not necessarily be directly functional to certain aspects of democratization, it is nevertheless politically highly relevant and valuable. Indeed it is absolutely central to the political predicament of some African countries, especially the more fragile nations with a history of social conflict like South Africa. ${ }^{1}$ Moreover it connects intimately with the twin emphases of Gero Erdmann's proposal: the prevalence of ethnicity-based parties; and the functional uses of informal political practice, which appears to be such a prominent feature of politics in Africa.

Before saying more about those two emphases, it is worth adding that if for analytical purposes we take democracy to be the overall object or end and yardstick for assessing parties' functional effectiveness, then we should consider attaching yet one more function to the fourfold list. Namely, what parties do to hold government to account, to restrain the executive, to check abuse of power and the misuse of public resources in particular ${ }^{2}$, most notably when in opposition. In the liberal democratic mythology this goes to the heart of what parties other than the party in power are there for; again, making it fully operational appears to be particularly problematic in Africa.

\section{Informal politics}

Turning now to the twin emphases let us first take informal politics and neopatrimonialism specifically. For sure this has sometimes been said to provide the 'glue', or 'cement', that holds a number of African societies together. But this remains plausible only as long as the rewards are distributed across the different ethnic, regional or other salient groups, and so long as there are enough rewards for the elite representatives of each group to share something with their traditional clients or supporters. This theme of the benign side of neopatrimonialism is cited, occasionally, in

1. For an extended examination of the problematic nature of oppositional politics in contemporary South Africa see Southall (2001).

2. For case illustration see Burnell (2001). 
the specialised but fast growing and intensely contested literature on why sub-Saharan Africa experiences a greater incidence of violent domestic or intra-state conflict than other regions. That observation is made here without offering a particular view on which among the various available explanations of violent conflict in Africa is most convincing. The candidates include: greed; grievance; institutional weakness in the political structures and government; and the wrong degree of ethnic heterogenity - there being considerable agreement that a multitude of different ethnic groups is far less conducive to conflict than the existence of just two or three groups, especially if political power is held and exercised on a non-inclusive basis (Burundi and Rwanda being good examples). ${ }^{1}$ The reluctance or inability of parties that have emerged from liberation movements to shed authoritarian tendencies and embrace democracy in their internal relations and external behaviour, may be cited as a further explanation relevant to some places, Namibia and Zimbabwe for example. It is a curious but not often remarked fact that very much less attention is given in this specialised literature to explaining why some countries that share many of the same predisposing conditions (great and growing poverty; increasing inequality correlated with differential access to and misuse of high public office; and so on) have managed to avoid significant violent civil conflict (and electoral violence specifically). ${ }^{2}$ Zambia offers one such case. ${ }^{3}$

So, in order to shed light on the different cases the role that informal structures like neopatrimonialism play in party politics and through that the constructive contribution that parties can or do make to social integra-

1. In recent years several journals have devoted special issues to violent conflict within states or Africa specifically, including: Journal of International Development, Vol. 15 (May 2003); Journal of Peace Research, Vol. 39, No. 4 (2002); Journal of Conflict Research, Vol. 46, No. 1 (2002); Journal of African Economies, Vol. 9, No. 3 (2000). In addition there is the two volume collection edited by Nafziger; Stewart and Väyrnen (2000).

2. Thus for instance Fearon and Laitin (1996: 717) note there is a need in political science for a theory to account not only for occasional outbreaks of ethnic violence but also for the much more common outcome of ethnic tensions that do not lead to sustained intergroup violence.'

3. For an attempt to explain the counterfactual - why a country that seems to have had some of the predisposing conditions for conflict has largely avoided internal political violence - see Burnell (2005). The article argues that a full explanation both has to call on multiple factors and incorporate a dynamic over time, to reflect the changing nature of the threats to peace - which in turn demand different sets of reasons showing why the danger did not materialise or how the threat potential was averted. In sum, static monocausal explanations are insufficient. 
tion or stability and peace, deserves all the attention we can muster. But in order to unlock some of the mysteries of informal politics in that context perhaps Africanists and other social scientists should first get together to discuss the comparative merits of formal versus informal research techniques or methods of inquiry for investigating Africa's informal politics. Some close observers of Africa like Thomas Bierschenk appear to believe there is not really a problem: ${ }^{1}$ investigators from outside simply ask the local people and they will freely share their knowledge and their views. Others remain suspicious that there must be more to it than that: what are the informal approaches not just to collecting evidence but to interpreting it and then authenticating the claims, especially where different but equally well qualified observers pool conflicting responses and reach divergent conclusions?

Notwithstanding the fact that neopatrimonialism might be dysfunctional for 'good governance' and rational economic management, through (mis)allocating scarce public resources in accord with political, particularistic and personal reasons only, the contribution it possibly makes to political stability (under certain circumstances) confirms that we must not exclude it from our analytical models. And just as important, neither should we rush to make normative judgments stressing the superiority of more formal political alternatives associated with the European political parties' literature. After all, it is worth reminding ourselves that the party literature on Italy (notably the now defunct Christian Democratic Party) and Japan (the omnipresent Liberal Democratic Party) is replete with references that evoke both the politics of patronage and neopatrimonial type arrangements. Similar tendencies seem to have come about in the new post-communist democracies, Ukraine for instance. Moreover it is not clear to this writer that spoils or comparable informal practices have altogether been banished from US politics either - note the coincidence of the vast sums of money amassed from business to finance the Republican Party's candidate for the White House in 2004 and alleged connections between VicePresident Dick Cheney and the awarding of plum government contracts to rebuild Iraq after its 'liberation' from Saddam Hussein.

So, although it might be correct to say along with Gero Erdmann that formal institutions 'need to gain the upper hand' in order to consolidate democracy, while certain informal practices underpin stability in the mean-

1. Comment during discussion session at the AEGIS thematic conference 'How people elect their leaders. Parties, party systems and elections in Africa south of the Sahara', Institut für Afrika-Kunde, Hamburg, 22 May 2003. 
time, the really challenging questions remain: When is it safe to mount an assault on the informal aspects of the web of politics? How would formal practices become dominant? Can political parties play a positive part in making it happen, or must the initiative rest with other institutions like the judiciary, anti-corruption commissions, civil society organisations and social movements and so on? And, if there is to be a trade-off at the margin between stability and democracy, what incentive structure do we suppose would lead the parties to regard such a risky trade-off as worthwhile? Indeed, is it worthwhile? And what time frame is envisaged, in a continent where, sadly, due to abysmal human longevity and obscene poverty, most people's time horizons including that of many politicians are inevitably short? Short-termism is indeed one of those defining characteristics of African politics, extending from the footloose commitment that many politicians show towards party loyalty (party switching is very frequent in countries like Zambia) to the poorly researched and pragmatic approaches that many parties both outside and inside government often take to the serious business of public policy formation and policy implementation (regarding public expenditure especially). All this has profound implications not just for the institutionalisation of parties and party systems but for the viability of durable solutions to deep-seated problems affecting the economy and society, such as too little sustained capital investment in the economy or the epidemic of HIV/AIDS, which in turn indirectly have consequences for party politics in the longer run.

\section{Ethnicity-based parties}

Perhaps even more significant than the informal features of African parties when it comes to maintaining and strengthening, or, if needed, creating or reconstructing social peace and fostering something like national integration, is the very notable proposal from the literature that we include in our typology of parties a special category of ethnicity-based parties. This implies, incidentally, that any suggestions claiming that Africa's parties are only tenuously linked to civil society and that civil society in Africa is weak may be valid only if civil society is defined in western liberal democratic terms. There is something to be said for siding with Nelson Kasfir on this issue (Kasfir 1998a; 1998b). ${ }^{1}$ Africa has a very rich and robust civil society, even if, just like Africa's version of political parties, it looks different (call parts of it pre-modern, or, 'non-civil', or, at the fringe even uncivil if you

1. See also Randall in this collection. 
will). And it is beyond dispute that many of Africa's parties do have firm anchors in this form of associational life, mediated through clientelistic networks and the like.

In regard to ethnicity-based parties, the distinction the literature makes between ethnic and congress variants looks especially fruitful for the purpose of understanding better the politics of accommodation in divided societies. Along with the other components of the proffered typology it gives some purchase on the issue of how parties might serve the purpose of social and national integration. This is particularly pertinent between elections, although it must be borne in mind that between elections many parties are only barely active, especially where the highly presidential nature of the government leaves parliamentary opposition parties with few opportunities to raise their profile. So it is especially pertinent where political leaders are tempted to resort to mobilising support along ethnic lines during the course of election campaigns. Simply abstaining from such an approach to campaigning may be insufficient to close down the possibility of violent conflict (both ethnic and non-ethnic related) breaking out as a result of profound dissatisfaction with poverty, gross inequality, and grievances concerning the way patronage is distributed. We are advised (by Liisa Laakso in 'Electoral violence in Africa', in this collection) that institutions like human rights non-governmental organisations, the attitude of the media and civic education all helped to depress violent tendencies during Kenya's elections in 2002. But it is worth finding out what more the parties can do in respect of integration, and how the differential performance of different parties in different countries in respect of this can be explained.

All in all the parties' typology as it has been adjusted for Africa inspires a host of questions that could fuel further research. Most are related to the theme of change (or its absence), and raising as a key issue the question of what potential exists for Africa's parties to change themselves, as distinct from them being prisoners of fundamental (but perhaps changeable and changing) sociological, cultural, financial, economic and other forces. Here are just a few of the possibilities:

- Can, and under what circumstances does, an ethnic party transform into an ethnicity-based congress party?

- Why does, or what is it that makes, an ethnicity-based congress party turn into something resembling more closely an electoralist party - and why does this happen only in some urbanising environments and not in others? 
- Does a shift of that nature require - or, perhaps, no less intriguing, does it actually cause - a movement away from reliance on informal political practices and towards cultivating more formally-based approaches to mobilising support and consolidating internal party cohesion?

- What are the conditions that would promote change from for example the personalistic sub-type of electoralist party to the programmatic sub-type?

- If the programmatic party in Africa's 'choiceless democracies' truly is a mirage, then can party differentiation in terms of claimed competence to govern and reputational integrity provide an adequate, sustainable alternative basis for structuring political competition? For instance this appears to offer a clue to explaining why the National Democratic Congress lost support in Ghana's 2000 elections (see Paul Nugent, 'Banknotes and symbolic capital: Ghana's elections under the Fourth Republic', in this collection). And if issues of governance credibility together with reputations for acceptable versus unacceptable ways of mixing money and politics really do constitute a viable basis for structuring political competition in the long run, would that require - or, would it enforce - a diminution in the presence of informal politics?

- Do the conditions as we care to specify them in answers to any of the above questions exist already in some parts of Africa, and if so, where? Are they likely to emerge in other countries in the near future, and if not, why not? And do the prerequisites that would facilitate and help produce these conditions lie in structural forces - political, or possibly economic and financial forces - that are beyond not just the control of parties in Africa but are beyond the whole of Africa's ability to influence?

Alternatively, does part of the 'solution' (if that is the right word) lie first in making certain specific formal institutional reforms, such as those concerning the arrangements for conducting elections and the choice of electoral system. Another possibility that has been much discussed in some of political science literature on institutional engineering in new democracies lies in reducing the powers that constitutions have attached to presidential rule, perhaps by altering the executive-legislative balance (Burnell 2002a, 2003). By giving the political opposition in legislatures a more meaningful role to play, parties will have greater incentive to remain active more or less continuously and could come to see their role as performing functions other than just mobilising votes on behalf of leading politicians in elections. 


\section{Conclusion}

To suggest such a large research agenda is, of course, the easy bit. The foregoing discussion is just as guilty as any other in not prioritising such questions as the ones it has raised - any more than the literature has provided us with a rank order of significance to organise the distinguishing characteristics of Africa's parties or the functions they perform, and any more than we have settled what the parties' principal objects in Africa should be and the appropriate time frame for making these judgments.

Here is not the place to set about providing answers. My guess is that not only Africanists who specialise in different countries in Africa, but also the different disciplines and the looking-glass through which each discipline views Africa will come up with different responses. But at least one thing is abundantly clear. There is no shortage of lines of inquiry around the fact that new thinking about Africa's parties, their special character, functional role and dynamic possibilities can help stimulate and profitably form the basis for further discussion and future research.

\section{References}

Bogaards, M. (2000), 'Crafting competitive party systems: Electoral laws and the opposition in Africa', Democratization 7: 4, pp. 163-190.

Burnell, P. (1998), 'Arrivals and departures: a preliminary classification of democratic failures and their explanation', Commonwealth and Comparative Politics 36: 3, pp. 1-29.

Burnell, P. (2001), 'Financial Indiscipline in Zambia's Third Republic: The role of parliamentary scrutiny', Journal of Legislative Studies 7: 3, pp. 34-64.

Burnell, P. (2002a), 'Parliamentary committees in Zambia's Third Republic: Partial reforms; unfinished agenda', Journal of Southern African Studies 28: 2, pp. 291-313.

Burnell, P. (2002b), 'Zambia's 2001 elections: The tyranny of small decisions, nondecisions and "not decisions", Third World Quarterly 23: 6, pp. 1103-1120.

Burnell, P. (2003), 'Legislative-executive relations in Zambia: Parliamentary reform on the agenda', Journal of Contemporary African Studies 21: 1, pp. 47-68.

Burnell, P. (2005), 'From low-conflict polity to democratic civil peace?: Explaining Zambian exceptionalism', African Studies 64: 2, pp. 107-133.

Collier, D. and S. Levitsky (1997), 'Democracy with adjectives: Conceptual innovation in comparative research', World Politics 49, pp. 430-451.

Cranenburgh, O. v. (1999), 'International policies to promote African democratization', in Grugel, J. (ed.) Democracy without Borders. London: Routledge, pp. 92-105

Diamond, L. (1996), 'Is the third wave over?', Journal of Democracy 7: 3, pp. 20-37. 
Diamond, L. and R. Gunther (eds) (2001), Politics, Parties and Democracy. Baltimore: The Johns Hopkins University Press.

Elklit, J. (1999), 'Electoral institutional change and democratization: you can lead a horse to water, but you can't make it drink', Democratization 6: 4, pp. 28-51.

Fearon, J.D. and D.D. Laitin (1996), 'Explaining interethnic cooperation', American Political Science Review 90: 4, pp. 715-735.

Gunther, R. et al. (2002), Political Parties: Old Concepts and New Challenges. Oxford: Oxford University Press.

Hagopian, F. (2000), 'Political Development, Revisited', Comparative Political Studies 33: 6/7, pp. 880-911.

Kasfir, N. (1998a), 'The conventional notion of civil society: a critique', Commonwealth and Comparative Politics 36: 2, p. 120.

Kasfir, N. (1998b), 'Civil society, the state and democracy in Africa', Commonwealth and Comparative Politics 36: 2, 123-49.

Kuenzi, M. and G. Lambright (2001), 'Party institutionalisation in 30 African countries', Party Politics 7: 4, pp. 437-468.

Levitsky, S. and L.A. Way (2002), 'The rise of competitive authoritarianisim', Journal of Democracy 13: 2, pp. 51-65.

Mkandawire, T. (1999), 'Crisis management and the making of "choiceless democracies"', in Joseph, R.A. (ed.) State, Conflict and Democracy. Boulder: Lynne Rienner, pp. 119-136.

Mozaffar, S. (2005), 'Introduction', Party Politics 11: 4, pp. 119-136.

Nafziger, E.W. et al. (eds) (2000), War, Hunger and Displacement: The Origins of Humanitarian Emergencies. Oxford: Oxford University Press.

Randall, V. and L. Svåsand, (2002), 'Political parties and democratic consolidation in Africa', Democratization 9: 3, pp. 30-52.

Rustow, D.W. (1968), 'Modernization and comparative politics: prospects in research and theory', Comparative Politics 1: 1, pp. 37-51.

Salih, M.M.E. (2003), African Political Parties: Evolution, Institutionalism and Governance. London: Pluto Press.

Salih, M.M.E. (2005), Globalized Party-Based Democracy and Africa: The Influence of Global Party-Based Democracy Networks. CSGR Working Paper. http://www2. warwick.ac.uk/fac/soc/csgr

Southall, R. (2001), 'Opposition in South Africa: Issues and Problems, in Southall, R. (ed.) Opposition and Democracy in South Africa. London: Frank Cass, pp. 1-24. 


\title{
Political Parties in Africa and the Representation of Social Groups
}

\author{
Vicky Randall
}

This chapter ${ }^{1}$ is concerned with the representative function of African political parties, specifically with the representation of social groups. It is primarily concerned with asking: In what sense and to what extent do African political parties represent social groups? Although there is general agreement on the importance of representation both for democracy and as something parties should be helping to provide, there is surprisingly little discussion of what this actually entails. The paper begins, therefore, by considering the concept of representation and suggesting the way it could be applied to parties. The following section asks how far the notion of party representation, as so far elaborated, is actually of relevance to political parties in democratizing Africa. I then consider party representation in relation to three kinds of 'social group': ethnic groups, civil society organisations and women.

\section{Concept of political representation}

In recent years, in the context of democratic 'audits' and more specific concerns with women's political participation, there has been a renewed interest in the concept of political representation. However this has generally been discussed in the context of established democracies in developed societies. The discussion has also been largely confined to electoral mechanisms or parliamentary arenas: it is very difficult to find any sustained reflection on the nature of representation in or through political parties as such.

The voluminous literature on (re-)democratization is generally very clear that political parties do or should play a crucial part in that process, and especially in so-called democratic consolidation. And amongst the various democracy-supporting functions of parties, that of providing a means of

1. I should like to thank participants at the Hamburg Conference, and in particular Aili Tripp, the discussant, and Matthijs Bogaards, for their helpful comments on the first draft of this paper. 
representation is considered central. Sartori, for instance, has said parties are or should be 'an instrument for representing the people by expressing their demands' (Sartori 1976; Doherty 2001; Randall and Svåsand 2002). But what is involved in this activity or process of party representation? What form(s) should representation take and how do we know if it is happening?

Both contemporary political theorists and the earlier writings distinguish between different forms of political representation, or senses in which it could be said that an individual, or collective body, represents a group, constituency or people. ${ }^{1}$ Broadly one could say these lie along a formalsubstantive axis. For purposes of the present analysis, the extremes of this continuum offer us least purchase. At one extreme, purely formal representation, or what Hannah Pitkin calls the 'authorization view', is when an individual can be said to represent a group of people to the extent that he or she has been selected to represent them through a formal procedure, notably through an election. At the other extreme, substantive representation is presumably maximised when delegates are mandated or directed by those they represent on how to behave and what to say. Arguably, the criteria for the first of these are too undemanding and for the second too demanding to assist a meaningful evaluation of parties and representation in Africa (or possibly anywhere).

A more interesting, though it might be argued still somewhat formalistic kind of representation is 'mirror' or descriptive, meaning that the representative shares certain defining characteristics with the group he/she claims to represent. In this sense the representative 'stands for' those represented. ${ }^{2}$ Pitkin (1967) was originally sceptical about the value of this kind of representation, pointing out, as many have since, that it provides no guarantee that a delegate will act in the interest of the group whose characteristics s/he shares. Feminist writers in particular have however revisited this question, especially in the context of gender quotas. It has been argued that even if there is no guarantee of more substantive representation, greater approximation to descriptive representation may be valuable as a means to correct a past, or present, injustice, or because of its symbolic message. But in addition more complex arguments have emerged around the suggestion that it may be necessary to be a member of a particular group in order

1. The classic text is Hannah Pitkin's The Concept of Representation, published in 1967.

2. Pitkin (1967) actually distinguishes two kinds of 'standing for' representation, the other kind being 'symbolic'. 
to fully understand the distinctive experiences that shape their actual or potential concerns (Phillips 1995: 70; Squires 1996). These intuitions are summed up in Phillips' phrase 'the politics of presence'.

In contrast to forms of representation that entail 'standing for', are more substantive and for Pitkin more valuable forms that involve in one way or another 'acting for'. And amongst these Pitkin advocates what is broadly a liberal view that the representative acts in the interests of those represented. ${ }^{1}$ However the representative is not assumed to know without consultation what those interests are. They need to consult with those they represent and to be responsive to their concerns. Pitkin (1967: 209) summarises this form of representation (which we shall label 'responsive') as 'acting in the interest of the represented, in a manner responsive to them'.

This is certainly an attractive formulation and one that probably comes closest to a contemporary common sense understanding of representation but even this notion is not as straightforward as it looks. For we must at this stage acknowledge, in the wake of post-structuralism, that the discussion so far has tended to take as given first the constitution of these 'groups' to be represented and second that at least to the groups themselves and however subjective their perception may be, the character of their 'interests' will be evident. Post-structuralists argue that

Members of classes (and by implication, genders and other interest groups) do not simply know their material interest, but have to form conceptions of them. Any connections among groups have to be constructed, articulated and maintained; they are not pre-given. Groups make these connections using the discursive frameworks available to the time and culture.... 'Interests', then, are precarious historical products which are always subjected to processes of dissolution and redefinition (Pringle and Watson 1998: 216).

We cannot assume either that 'groups' exist objectively out there - certainly not as self-conscious, cohesive entities - or that they will have a clear perception of their own interests. Rather, both groups and their interests are to an extent constituted through the political process itself.

\section{Political parties and representation}

So how does this help us to think about parties and representation? Birch noted thirty years ago 'It is a remarkable fact that most theoretical writings

1. She distinguishes several other forms of acting which include: acting as an agent, as a trustee or guardian, as a deputy or as a delegate. 
about political representation have ignored the existence of organised parties' (Birch 1972: 97) and surprisingly perhaps this continues to be the case. Birch himself, with the British party system very much in mind, focuses on the question of party discipline. How can the commitment to internal party discipline, historically associated with parties representing the disadvantaged and formerly disenfranchised breaking into the privileged sphere of parliamentary politics, be reconciled with broader understandings of political representation? He suggests that the theory that has emerged to justify this practice is that of the 'electoral mandate': parties present clear programmes for the electorate to choose between and then have not only a mandate but an obligation to deliver them. This of course presupposes that parties do present, and then act on, coherent programmes and that those who vote for them do so on the basis of these programmes - conditions, Birch argues, that are seldom realised.

Birch's discussion of party discipline is not irrelevant to the present paper, in so far as it draws attention to the conceptual and practical tension between parties on the one hand, and ideally, in mutual ongoing dialogue with social groups they represent and on the other seeking to capture or hold onto governmental power in order to fulfil some preordained mandate or 'historical mission'. Otherwise, however, given the absence of a literature more directly focused on parties' role in representation, I suggest that we should focus on parties' role in promoting both descriptive forms of representation and more responsive modes. And without getting too bogged down in the logic of deconstruction, we should, again ideally, also be asking how groups are defined, by whom, and how they are given 'voice'. Do parties themselves help to create groups?

Furthermore we need to consider how these forms of representation are furthered both within the party and through the party. In examining forms of group representation within a party, and assuming the information was available, we should want to know how far on the one hand the grass-roots 'membership' and on the other the party leadership mirrored and/or advanced the interests of the groups in question. Ideally we should also like to know how these interests were filtered through intermediate levels of party officials and activists, party candidates and so forth. How far was there provision for the representation, in any sense, of particular groups collectively for instance as sections within the party or affiliated bodies? In examining group representation through the party, we should want to know about links between the party and constituents of those actual or potential groups; how the party selected its candidates for local and national 
elections; what kind of platform, implicit or explicit, the party contested elections on; how the party's delegates conducted themselves in legislative arenas; and, where relevant, how its leadership acted in government.

\section{Analysing parties and representation in sub-Saharan Africa}

Whilst it may be helpful to clarify what kinds of questions in principle we ought to be asking about political parties and the representation of social groups, there are at least two objections that could already be raised to pursuing this approach much further. The first might be that such questions are essentially derived from a western democratic experience and are beside the point in the context of African party politics, failing to reveal what is actually going on. Thus Chabal and Daloz (1999: 39), maintain that in African political systems a particular understanding of representation is entrenched which is 'firmly anchored ... in the patrimonial system'. This means, for instance, that on the whole, voters 'do not vote because they support the ideas, even less read the programmes, of a particular political party, but because they must placate the demands of their existing or putative patron'. Similarly Van de Walle and Butler (1999: 26) observe that 'In Africa today ... parties do not really serve to aggregate interests; rather they serve a representation function in a context of clientelistic politics'.

The provisional response to this objection is firstly to agree that clientelism is a central fact of African political life but also to suggest that its incidence varies and that it is not necessarily the only form of linkage between people and party. Furthermore it does not operate in a social vacuum but combines with other bases of social interdependence notably ethnicity and regionalism. Finally rather than ignoring clientelism, we should try to understand what form(s) of representation it signifies, and more specifically how it relates to mirror or responsive representation.

The second objection is simply the shortage of readily available data that would allow us to investigate our questions about parties and group representation in a systematic way. Is the analytic framework too elaborate or sophisticated for its subject matter? Indeed, this objection has some basis and I can only say that what follows in this paper is a very preliminary attempt to apply the framework, relying almost entirely on accessible secondary sources.

The broad thrust of this secondary literature on political parties in democratising Africa is certainly not encouraging as far as group representation, whether of a more descriptive or responsive kind, is concerned. In 
general, and as summarised for instance in Van de Walle and Butler (1999), and Randall and Svåsand (2002), parties are depicted as organizationally weak, often no more than small and transient vehicles for the ambitions of individual politicians. Typically opposition parties are urban-based and have proven 'extremely weak when it came to reaching out to people in the rural areas where the bulk of the people - and the voters - are concentrated' (Olukoshi 1998: 32). Such opposition parties with extremely limited resources have often become dependent on funding from external donors, which 'donorisation' has in turn reinforced elitist tendencies and lessened any initial incentive to cultivate a mass following (ibid.).

Party 'membership', if formalised at all, may imply very little about expectations of members' rights and duties. Such is the case of the opposition parties in Tanzania described by Kelsall whose membership is often disproportionately composed of young men looking for patronage, rather than dues-paying members. He quotes one former opposition party leader saying 'They were all hungry boys, coming to see me, begging "Give me some tea, give me some bread”...' (Kelsall 2003: 60). Before the General Election held 2002 in Kenya, Oluoch reported 'With growing poverty and competition for membership, few parties would dream of asking members to pay heavy subscription fees. In most elections, candidates buy Ksh 10 membership cards and distribute them free to supporters' (Oluoch 2002: 2).

Commentators like Van de Walle and Butler further note the 'absence of differentiation of parties along programmatic lines. Ideological differences have been minor and debates about policy have been virtually nonexistent' (1999: 23). Thus, for instance, Wanjohi (2003: 251) tells us

... nearly all party manifestos in Kenya look alike, often using the same phraseology, and even identical paragraphs... The larger parties are often keen not to produce their policies and other documents too early before an election for fear that others will simply copy those documents with impunity.

And as for parties' representative role within the national legislature, Van de Walle and Butler suggest that this is in many respects a 'sideshow'; the struggle for legislative seats is to gain majority status but also, especially in the case of smaller parties, the attention of the executive. A symptom of this attitude is the widespread practice of 'floor-' or 'carpet-crossing' (Fomunyoh 2001).

If such characterisations, together with insistence on the all-pervasive logic of neo-patrimonialism, suggest that there will be little scope for processes, and especially deliberate processes, of political representation of dif- 
ferent social groups per se, however, a second and possibly contradictory broad impression from the literature is the salience of ethnicity as a basis for political party formation and strategy. ${ }^{1}$ Thus Ottaway (1999: 311) refers to the 'overt or covert ethnic character of the majority of the emerging political parties'.

In the rest of this chapter I seek to explore further the questions raised so far. Though restricted to a degree by what material is available, I concentrate primarily on those countries where party competition is reasonably well established. Given the universe of political parties, I also pay most attention to those which are significant political players, whether this is determined through the Laakso-Taagepera (1979) formula or simply includes 'effective parties' and relevant parties, that is main parties as well as parties with blackmail or coalition leverage (Sartori 1976), as opposed to that much more numerous category which are ephemeral and hastily improvised instruments for aspiring politicians (a phenomenon not unknown in Western democracies be it said).

Obviously in an exercise of this kind it is only possible to examine a few of the potentially numerous social groups with which parties interact. 'Social group' itself is a highly general category whose coverage could range from broad socio-economic classes or strata to highly exclusive status groups. I could for instance have looked at town dwellers versus the rural peasantry or at the representation of religiously differentiated groups. The number of religiously-based parties though still small is growing and includes Kenya's Islamic Party and South Africa's Christian Democratic Party (Salih 2003). My selection has been governed by time constraints, by my own current interests and to an extent by the emphasis of the existing literature. I look in turn at the representation of three social categories: 'ethnic' groups - where there may be some question about how far these groups are 'socially' constructed; civil society associations which have a corporate self-awareness almost by definition; and 'women' whose 'objective' existence as women at an individual level would not usually be problematised (except of course by writers like Judith Butler) but who may well lack any sense of a collective identity or interest.

1. See for instance Young 1999; Lawson 1999; Ottaway 1999; Van Walraven 2000; Van de Walle 2003 


\section{Political parties and ethnic identity}

There is an extensive and politically charged debate about the extent to which ethnic identity is an objective attribute or has been socially constructed, in the process of social interaction between different sets of players, including originally colonial occupiers. At any rate I have already noted the repeated observation in the literature that ethnicity is a central theme or element of African political parties. Ottaway suggests this tendency has been accentuated by the discrediting of socialist perspectives. Only Islamic parties, she suggests, have retained an ideological appeal capable of cutting across ethnic divisions. The swiftness of transition also often meant parties had little time to develop new programmes. In sum 'The absence of ideological and programmatic differences left ethnicity as the major characteristic by which the various parties could differentiate themselves' (Ottaway 1999: 311).

The salience of ethnicity is recognised, despite the fact that many governments have banned the registration of parties that are obviously ethnically-based. For instance in Tanzania the Constitution forbids the formation of parties or electioneering on the basis of race or religion; in Cameroon a law passed in 1990 explicitly rejected any party discriminating on the basis of ethnicity, province, language or religion; similar provisions are to be found in Ghana's 1992 Constitution. Such measures have of course gone furthest in Nigeria, beginning back in the Second Republic. Nor need appeals to ethnic loyalties be overt - Sithole (1995) observes that in Zimbabwe it is rare find a politician explicitly campaigning on ethnic lines but voters will still vote on the basis of ethnic identities.

But whilst the salience of ethnicity in party politics seems incontrovertible, there remain a number of questions about how and in what sense parties represent ethnic groups. Scarritt and Mozaffar (2002) question, firstly, how far these really are 'ethnic parties', if, following Chandra and Metz, an ethnic party is defined as 'a party that overtly represents itself to voters as the champion of the interests of one ethnic group or set of groups' and the key distinguishing principles are 'overtness, exclusion (and) centrality' (Chandra and Metz 2002: 5). On this basis, they maintain that 'there are many multiethnic parties and few ethnic parties in African countries'. The number and proportionality of ethnic groupings vary substantially from country to country (and to a lesser extent over time of course) and with them the possible parameters of ethnic politics. Thus Kelsall (2003) argues that in Tanzania, where there are reckoned to be 127 small ethnic groups, ethnicity is a problematic resource for a party. In such a situation, the party 
that defines itself as ethnic, in the sense of representing a single ethnic group, is almost certain to lose.

There is a further question as to what is actually being represented: In particular is it ethnicity or is it regionalism? This is not the place to rehearse the debates about the complex nature of ethnicity, although one of the possible bases of ethnic identity is sometimes said to be living in the same region, which could certainly confuse matters. In fact numerous studies of recent elections in tropical Africa, given the frequent tendency for concentrations of particular ethnic groups to coincide with administrative region boundaries, refer to 'ethno-regional' identities (for instance Nugent on Ghana, 2001). However, supposing that ethnicity and regionalism are distinct bases of political identity and behaviour, then in studies of some national elections the suggestion is made that what looks like or is described as ethnically-based voting is really regionalism. Kaspin's thoughtful analysis of the 1994 presidential and parliamentary elections in Malawi provides one example. The election results, which showed a marked association of votes cast for the three main parties with specific ethnic groupings, were widely interpreted as demonstrating the ethnic basis of politics in Malawi. However Kaspin argues that regionalism was at least as significant as ethnicity (together with a third factor, reaction against the previous regime). Ethnicity was most important in explaining support for the former ruling party, the MCP, but less for the other two except in the sense that being non-Chewa was a rallying point. Ethnicity to a degree coincided with identification with administrative regions inherited from colonial times but detailed examination of the results showed that where ethnic and regional boundaries diverged, in many cases regionalism overrode ethnicity (Kaspin 1995). Similarly Azavedo (1995) suggests for the 1992 presidential and parliamentary elections in Cameroon, that although ethnic groups voted en bloc this was more on the basis of regionalism than of ethnicity itself.

But thirdly, to the extent that parties are identified by their leaders and/ or in the public mind with one or more ethnic groups, in what sense are they representing those groups? Certainly there can be expected to be a high degree of mirror or descriptive representation. Those identifying with a particular ethnic group will vote for and support party leaders drawn from that group and those leaders will, more or less overtly, appeal to their ethnic confrères. But here ethnicity is generally assumed to combine with clientelism. In a simple model of how this works, party elites play on ethnic divisions 'as they compete for positions of ascendancy over political decisions, especially the allocation of public resources' (Osei-Hwedie 1998: 
230). Voters/supporters in turn expect their party, or its leaders, whether at national or local level, to ensure that forms of government patronage percolate down to them. That is, one might say, the leaders, by virtue of their shared ethnic identity, are presumed to promote the material interests of the ethnic group. So descriptive representation becomes a pledge or sign of responsive representation.

Actually, though, and in situations where for familiar reasons (neo-liberal policy prescriptions, austerity programmes and so on) in recent years government resources available for patronage may have been severely limited, the distribution of patronage may not reach beyond the inner circle of the party leader(s) and followers. Van de Walle argues, on the basis of his own fieldwork, that it is more useful to think of clientelism primarily as a mechanism for the accommodation and integration of a fairly narrow political elite, with most of the material gains from clientelism limited to this elite. Then the link between this political or party elite and its supporters is through the less tangible bonds of ethnic identity (Van de Walle 2003). This suggests that the representation of ethnic groups takes a primarily descriptive form, but with a margin of ambiguity as to how far shared ethnicity signifies representation of shared interests.

How then is this relationship between party leaders and ethnically similar supporters sustained? It may be that the assumption of shared interests has a historical basis and could give way to disillusion if material benefits are withheld for too long. But we may also need to modify our expectation that voters will be motivated by a direct calculation of self-interest in supporting party leaders from their own ethnic group. To use a longstanding distinction it could be regarded as expressive rather than instrumental behaviour. Relevant here is a comment by Chabal and Daloz on the way in which the ostentatious living of political leaders is not necessarily resented by the ordinary African. 'On the contrary what is noticeable is the extent to which the less fortunate show their appreciation of the manifestation of ostentation or show, as though it reflected well on them. Wealth thus revealed appears, indirectly, to be a symbol of their collective prominence, according to a process which we identify as "vertical symbolic redistribution" (Chabal and Daloz 1999: 42). (This is somewhat reminiscent of Machiavelli's advice to the Prince who wanted to get and retain power not to offer citizens a direct share in the exercise of power but rather the reflected glory that came from identification with great men.) Writing about Kenya, Muigai also reflects on why the 'masses' themselves perceive their interests as being served when members of their ethnic groups are impositions of 
power and influence. He suggests that 'When members of an ethnic group have access to the resources of the state, not only do they believe that they benefit as individuals but also that their kinsmen have greater opportunities in all spheres controlled by the state' (Muigai 1995: 169).

In conclusion, whilst the salience of ethnicity in political discourse and party calculations in Africa is beyond question, the number and patterning of ethnic identities means that truly ethnic parties, based largely on a single ethnic group, are likely to be rare or at least unsuccessful. Much more typically they will be multi-ethnic, corresponding to the category of 'ethnic congress parties' in Gunther and Diamond's party typology (2003). Supposedly ethnic bases of partisanship may also in fact sometimes be better described as regionalist. But we also have to ask how far and in what sense ethnic groups are actually represented in and through parties. Descriptive representation is almost axiomatic but it is much less clear that this ensures representation of interests, even the form of interest representation provided through clientelistic mechanisms.

\section{Representation and 'civil society'}

From considering how parties represent ethnic groups, we turn to civil society. Civil society is a highly contested concept but following Ottaway (2004) will be equated here with the realm of voluntary citizen associations, existing between family and state, and largely independent of the latter, which seek to influence public policy without aspiring to public office. As such they span a wide range of associations but, in a sub-Saharan African context could include professionalized NGOs working in areas closely related to democratization, but also interest groups such as trade unions and employers' associations, church-based organizations and so on. As explicit organisations, we can assume that civil society organisations (CSOs) have some pre-given sense of identity. They also differ from either ethnic groups or women in being already situated within the 'public' sphere and often seeing themselves or being seen as standing for, that is, representing, some wider category of people. This makes the question of how far parties' representative role extends to CSOs in one sense more complicated. Are we interested in party representation of the CSOs themselves and/or of the people the CSOs stand for?

The substantial literature on civil society in tropical Africa tends to be sceptical about how far the positive, pro-democracy, civic, connotations the term 'civil society' has acquired in western political science are appropri- 
ate for the African context (Callaghy 1994; Kasfir 1998) and in general to depict civil society as weakly developed and lacking in autonomy (GyimahBoadi 1997). However it is a variable picture. Kelsall (2003) suggests that associational life in Tanzania is weak, because of the colonisation of civil society by the party-state under TANU. It lacks a significant trades union, cooperative or human rights movement with a history of independence from the state. But this can be contrasted with Ghana, Kenya, Senegal, South Africa, Zambia and Zimbabwe where civil society has been more vigorous and individual CSOs have played an active role in promoting democracy. Major opposition parties - notably the MMD in Zambia, Adema in Mali, both of which subsequently came to power, and most recently the MDC (Movement for Democratic Change) in Zimbabwe - were originally formed out of coalitions that included CSOs.

In the wider literature on democratization in developing countries, notably in Latin America, there has been much discussion of the tendency for civil society movements or organisations that were prominent in bringing about political liberalization subsequently to disappear from the political scene, raising the question of how far they had been 'colonized' by political parties (Lanegran 1995). In the African context, with certain exceptions, notably the ANC, parties rather than colonizing CSOs apparently make little effort to work with or through them. Widner (1997), provides the only extended survey of the relationship between CSOs and parties in tropical Africa. In addition to a range of democracy-oriented NGOs, she notes the proliferation from the 1980s of new forms of association based on common economic interest, including trade associations, consumer groups, transporters' organizations, parent-teacher associations and student leagues, but finds that only a handful of political parties have sought to appeal to the interests that such horizontal associations represent. She suggests a number of reasons for this. One is that the actual membership of such groups is very low - "Under these conditions, to assemble a significant vote base, party leaders must "press the flesh" with many members of these groups. This is a very time-consuming and costly prospect' (Widner 1997: 77). Moreover leaders of such associations will not necessarily be able to deliver their members' votes. A further reason is that such organisations tend to be urban-based lacking links to rural areas. The exceptions are churches and teachers' associations but churches generally want to avoid being identified with a particular party while teachers are dependent on the government.

If parties generally do not seek close organisational links with CSOs, then Burnell, discussing Zambia, points out there are likewise reasons why 
CSOs may eschew too close a relationship with parties. In Zambia in the 90s he suggests that the most prominent civic associations have been bodies like the Zambia Independent Monitoring Team and the Foundation for Democratic Process. Too close an association with opposition parties 'would not only compromise their own independent role but could make them a more obvious target of harassment. No less important it would be likely to jeopardise the moral support they receive from international organisations like Human Rights Watch Africa and Amnesty International and the many funding links they enjoy with foreign government and well as non-governmental donors' (Burnell 2001).

It is worth considering trade unions separately, since in western democracies many political parties conventionally placed on the left of the ideological spectrum have either originated in or been closely associated with them. In African countries trade unions have generally been weak, and compromised by the fact, noted by Bratton and Van de Walle (1997), that most organised labourers are government employees. The bargaining position of trade unions has been further weakened in recent years by the adoption of neo-liberal economic policies. Unions played a significant part in launching the MMD in Zambia and MDC in Zimbabwe. However, subsequently, and doubtless partly due to external economic pressures, these parties have not necessarily 'represented' unions or their members. According to Burnell (2001), whilst the MMD has been in power, formal sector employment in Zambia has shrunk by more than half, there have been large reductions in public sector pay and the Zambia Congress of Trade Unions itself has split. In Zimbabwe, the MDC is led by a trade unionist, Morgan Tsvangirai, but as Van de Walle (2003) observes that party has not staked out a policy position markedly to the left of ZANU-PF or put forward labour issues.

South Africa might seem to offer a partial exception to this pattern. A substantial industrial workforce emerged much earlier than in other regions of sub-Saharan Africa and an alliance between the ANC, South African Communist Party (SACP) and South African Congress of Trade Unions (SACTU) dates back to the 1950s. With the formation of COSATU (the Congress of South African Trade Unions), which subsumed SACTU, in 1985, the association was strengthened and it was formalised in the famous tripartite alliance in the early 1990s (Habib and Taylor 2001). So COSATU's history has been intertwined with that of the ANC and it was COSATU, together with the SACP, which originally conceived the Reconstruction and Development Programme (RDP), adopted as the unifying 
government policy framework after the 1994 general election brought the ANC to power. In this case it would seem clear that both COSATU and the interests of the unionised workers it represents were in turn represented both in the decision-making process and the policy choices of the ANC. Indeed, as prospects for multi-partyism in South Africa appear to dim, especially following the 1999 and 2004 General Elections, some share Lijphart's hopes that the ANC itself will become a kind of consociational party like the Congress Party in India (Lijphart 1998).

However, COSATU's contribution to the RDP had been diluted by contributions from a range of other interests, resulting in a programme that was 'both contradictory and vague' (Friedman 1999: 120). In 1996 the ANC government launched its new macro-economic policy, the Growth, Employment and Redistribution Programme (GEAR), committed to strict neo-liberal precepts seemingly incompatible with the RDP. Although COSATU produced in response a discussion paper highly critical of both the process through which GEAR was adopted and its content, according to McKinley (2001) the ANC leadership came down heavily on its critics. By the 1999 General Election, 'Through a combination of outright political intimidation, ideological mysticism and the co-option ... of key ANC trouble-makers and COSATU/SACP leaders into his government inner circle, Mbeki had largely succeeded in squashing genuine opposition and controlling the boundaries of debate' (McKinley 2001: 200).

In general, it appears that political parties in tropical Africa make little effort to build links with pre-existing civil society organisations and through them to represent the wider social groups the CSOs represent, because they have few incentives to do so and also because such organisations may be wary of too close an association with any particular party. Although in some cases, as in Mali and Zambia, CSOs played their part in the opposition coalition that overturned the government, they did not necessarily exercise much influence in the new ruling party thereafter and as Burnell describes, in many instances may have actually sought to distance themselves from it. The case of COSATU, supposedly a partner in the ANC-led triple alliance, in South Africa, may seem an exception to this general pattern, but even then recent developments in its relationship with the ANC highlight the difficult balancing act of enjoying influence within the party without being taken over and silenced by it. 


\section{Representation and women}

We can consider, thirdly, how parties represent women. By 'women' we are referring directly to female adult members of the population as a category but we need also to consider the relationship between political parties and women's organisations, which can be seen as a sub-set of CSOs. Especially when we are concerned with women as a category, as with ethnic groups, the mirror concept of representation is relevant - to what extent are women included as members of parties, within the party hierarchies, as party candidates for political office and so forth? But at the same time we need to ask about responsive representation, including how this is linked to mirror representation, and not only if but how 'women's interests' are identified and framed.

Although there are celebrated exceptions, notably in Scandinavia, the general finding across the globe has been that women are greatly underrepresented in and through political parties in almost any sense you care to mention, and this should not be forgotten when reviewing experience in sub-Saharan Africa. If we focus first on women's mirror representation, there have been almost no women party leaders, one previous exception was in Benin where the former president's wife, Rosine Soglo, used to lead the 'Renaissance du Benin', but a much more noteworthy recent addition is Ellen Johnson-Sirleaf, leader of the Unity Party in Liberia, where she was elected President in 2006. Figures available from the Inter-Parliamentary Union show women as a per centage of parliamentary deputies ranging from seven per cent in Benin (following elections in 2003) to 33 per cent in South Africa (dito 2004), 35 per cent in Mozambique (2004) and no less than 49 per cent in Rwanda. ${ }^{1}$ Rates of women's representation in this specific sense have been highest where parties have specifically adopted a gender quotas policy. In 2001 parties with gender quotas for parliamentary candidates could be found in five tropical African countries - Equatorial Guinea, Mozambique, Namibia, Senegal and South Africa ${ }^{2}$ (Yoon 2001). The ANC's 30 per cent quota helped to ensure that of the 100 women elected to the House of Assembly in 1994, 84 were ANC members and of 119 women elected in 1999, 97 are ANC members; moreover 8 members of the 29-strong cabinet formed after the 1999 election are women. Similarly FRELIMO's gender quota in Mozambique, - the quota for women was set

1. Figures available from the website of the Inter-Parliamentary Union www.ipu.org/ wmn-e/classif.htm.

2. Tanzania has a constitutionally legislated quota of seats for women in parliament. 
at one third of the party list and in the end 35 per cent of the candidates were women - was a main reason why of 62 women elected in 1994, 48 were FRELIMO members. Namibia, where for the 1999 General Election, 19 out of 72 of SWAPO's candidates were women (Lodge, 2001: 201), Senegal (following the 2001 election) and Equatorial Guinea (2004) also currently have relatively high rates of women's parliamentary representation at 27, 19, and 19 per cent respectively. Overall it seems clear that parties, or at least dominant or major parties, that have adopted gender quotas have boosted the numerical or mirror representation of women ${ }^{1}$.

Why have individual parties adopted gender quotas? The ANC, SWAPO and FRELIMO were all parties grown out of movements of national liberation. Women had played their part within the liberation struggle and in the case of the ANC at least, women activists had pressed directly, and indirectly through the cross-party Women's National Coalition, for increased representation in decision-making arenas. Goetz and Hassim (2001: 8) suggest further that this pressure coincided with the party's need to demonstrate its democratic and inclusive character: "women" came to occupy a peculiar status as the proving ground for the extent to which the new order would be inclusive, participatory and permeable to socially excluded groups'.

But does this increased numerical representation translate into more substantive or responsive representation of women? We have first to ask what responsive representation would mean. What are women's interests? Women do not necessarily see themselves as constituting a group, sharing common interests. They may be much more inclined to identify themselves in ethnic or regional terms, for instance. We have also seen that many feminist theorists these days question notions of women's shared 'objective' interests at all. Phillips has argued that rather than suggesting women have a unifying set of interests it is enough to show that they have some experiences not shared by men, her example being childbirth, meaning that on such issues men cannot properly represent them. But even this argument may be less plausible in societies marked by stark social and economic inequalities. Vincent, reflecting on its relevance for gender quotas in South Africa, goes so far as to say 'It is genuinely impossible to find any substantive common ground in the way in which middle-class white South African women and rural African women experience childbirth' (Vincent 2002: 4).

1. Although in the case of Rwanda, the sensational 49 per cent resulted from nationally established quotas in parliament, not quotas adopted by parties. 
But leaving aside the question of whether, theoretically speaking, it is possible for women in party elites and as members of parliamentary parties to represent the authentic and full range of women's interests, we can consider how far in practice women's increased descriptive representation has been accompanied by more gender-sensitive policy-making. Information available mainly concerns South Africa, but even here the picture is ambiguous at best. Goetz and Hassim (2001), whilst not glossing over the difficulties faced by women within the ANC, point to three 'path breaking' pieces of legislation that have coincided with larger numbers of women legislators: the Termination of Pregnancy Act in 1996, and the Domestic Violence Act and the Maintenance Act in 1998. On the other hand, Vincent is clear that 'the level of participation on the part of the ANC's quota of women has not been in proportion to their numbers' (Vincent 2001: 75), and suggests bitterly that 'the ANC's quota has done little more than advance the careers of a select group of already well-educated, politically highly well-connected women' (2002: 5).

Parties in Africa often include organisationally distinct 'women's sections' or closely affiliated women's organisations. Accounts of the experience of party women's sections in western democracies suggest that traditionally they have been viewed as essentially auxiliary bodies through which to recruit women's support and in which women have been expected to occupy themselves in ways echoing their domestic role and concerns, rather than as a part of the party's decision-making machinery. It was only as they were touched with the fire of feminism that many became bases of women's activism, demanding better representation for women within the party hierarchy and as party candidates for elective office and advocating a range of policy changes. Women's sections in African parties seem not to have been so different. Geisler describes, for example, Zambian women's experience in the UNIP Women's League back in the 1950s. It was always understood to be an adjunct of the main party and only acted in specific projects, typically voluntary work such as adult literacy classes, 'funeral committees' and other welfare-oriented activities. (In those days, women needed their husbands' permission to take part and even then would be criticised by other women for doing so.) More recently she notes how in Zimbabwe where women had played an active part in the armed struggle, by 1994 the mandate of ZANU (PF) Women's League had changed from military objectives to social welfare (Geisler, 1995). Umoja wa Wanake wa Tanzania, affiliated to Chama Cha Mapinduzi in Tanzania, the Organization of Mozambican Women (OMM), and the 31st December Movement 
in Ghana play a similar role. The OMM made a bid to break away from the ruling party, FRELIMO, in Mozambique, with the advent of multi-party competition in 1990 but six years later opted to rejoin 'having remained a de facto FRELIMO mass association unable and unwilling to shake off its party affiliation. FRELIMO, for its part, needed the OMM to build its own voter base' (Tripp 2000: 11). The 31st December Movement is a women's organisation closely affiliated to the former ruling party, the National Democratic Congress, and founded and led by the former President's wife, Nana Konadu Agyeman Rawlings; a major part of its activities have focused on fund-raising for election campaigns (Nugent 2001). In Botswana's ruling BDP, women's league congresses have served as a 'testing-ground' for the strength of factions prior to general party congresses. Again the partial exception to this pattern is South Africa, where the ANC Women's League (women's section) has automatic representation in the party's highest decision-making body, but still, apart from a brief period in the early ' 90 s when the Women's National Coalition (discussed further below) was active and the League articulated a strong feminist position, "it has not managed to break free of its "tea-making" role, ... has not taken a consistent position on gender issues or assumed any leadership role in the women's movement' (Goetz and Hassim 2001: 20; Geisler 2000).

If women's substantive representation directly in and through political parties has generally been so limited, is the representation of women's interests more likely to be advanced if they organise independently of parties? This can of course be seen as part of the wider issue addressed above of how CSOs in general should relate to parties and it is also a question commonly raised in the literature concerned with women and democratization, as summarised in Waylen's notion of the dilemma of 'autonomy versus integration' (1994). Tripp in particular has argued strongly for the need for women to organise independently of parties and for their organisations to cherish and defend their autonomy, so as not only to be able to engage the state more effectively but to protect a space free from the constraints of party hierarchy and patronage networks in which to define their own agenda. Goetz and Hassim, however, reflecting in particular on women's experience in South Africa and Uganda, believe that 'for most women's movements in Africa, there is little choice about whether to work with political parties'; more specifically women seeking change have little choice but to work through dominant parties based on former national liberation movements, where these exist. 'Liberation movements - precursors to parties - have been the primary vehicles for women's political participa- 
tion. In the post-liberation period, whether they institutionalise as parties, as in South Africa, or cling to the more amorphous "movement" form, as in Uganda, they remain the central mechanism for channelling political demands' (Goetz and Hassim 2001: 4).

In practice women's organizations seeking to influence political parties from outside have generally had very limited success and have often encountered considerable suspicion and harassment. For example, Geisler describes the National Women's Lobby Group formed in Zambia in 1991 in response to the constitutional amendment allowing multi-party elections. Although, on her account, the Lobby could have done more to support women who did come forward to contest the elections, it did protest subsequently when none of the eight new women MPs were appointed to the cabinet. But from 1992 it faced growing hostility from the leadership of both UNIP and the MMD (Geisler 1995). Once more the exception has been in South Africa, where the Women's National Coalition formed in 1992 with a membership of 92 national organisations, including women's sections within most political parties, campaigned to mobilise women at grass-roots level and influence the drawing up of the new Constitution (Geisler 2000). Goetz and Hassim (2001: 7) acknowledge that 'Its autonomy was ... a primary source of strength'. To an extent women in the National Coalition, as in the ANC's Women's League at that time, had learned from women's experience after participation in other national liberation struggles of the dangers of being assimilated and depoliticised and in turn the experience of the WNC served as an inspiration for women's movements elsewhere in southern Africa. Even so, given the diversity of its membership, Goetz and Hassim suggest it was better equipped to pursue demands for women's representation than more radical constitutional demands for recognition of socio-economic and reproductive rights, and certainly after 1994 it lost momentum.

Women's descriptive representation in and through political parties has been limited in African political parties as indeed everywhere but has improved dramatically over the last decade in cases where parties, typically parties based on national liberation movements, have instituted gender quotas. In general this has not meant a significant increase of responsive representation however. Women's sections in parties have also been and generally remain marginal auxiliary bodies. The alternative strategy for advancing women's interests through parties, by bringing influence to bear from relatively autonomous women's organisations, notwithstanding the 
striking achievement of the Women's National Coalition in the early 90s, appears hazardous and not necessarily more fruitful however.

\section{Conclusions}

This chapter's main concern has been with exploring the nature and degree of social group representation in and by political parties, with particular reference to ethnic groups, civil society organisations and women. One initial conclusion must be the need for much more systematic research, both quantitative and more ethnographic, into the extent and nature of African political parties' relationship with their social base. The more general if provisional conclusion from this rather sketchy overview must be that African political parties in general may offer some degree of descriptive representation both for ethnic groups and increasingly for women but that evidence of more substantive, responsive representation of these social groups or of civil society associations and the people they represent is much harder to find. Whilst (some) ethnic groups may appear to enjoy a form of substantive or interest representation, through the processes of clientelism, in reality it may be closer to symbolic collective representation. Of course we should remember that political parties in established democracies do not necessarily or always constitute meaningful channels of social group representation either.

Although the discussion did not directly set out to identify the circumstances under which group representation of whatever sort was more likely, one further conclusion must be that we need to differentiate between parties. It is parties that have emerged through the coalescing of forces that are 'pro-democracy' and seek to overthrow the incumbent party associated with authoritarian rule, and still more parties that are based on popularly-based movements of national liberation which are most likely to offer spaces for the (definition and) representation of interests of social groups like 'women' and organised labour, at least in the period of transition whilst mobilization levels are still high and before external economic pressures and conservative vested interests (re-)assert themselves.

But this very experience of representation through new ruling parties of national liberation raises a further more normative question. The argument so far has tended to assume that we should want parties to be socially representative and to concentrate on establishing empirically whether they are. However the case of these 'movement' parties must lead us to question how far, from the point of view of social groups themselves, or even democracy, 
it is desirable that such parties should be allowed to take on responsibility, certainly exclusive responsibility, for the expression and furtherance of interests that remain so vulnerable to marginalization and redefinition.

All this may sound very negative. Pitkin (1967: 240) talks about an inevitable tension between the ideal of representation and what has actually been achieved. This is all too apparent when we consider how African political parties represent social groups or their interests. But as Pitkin says, this should not lead us to abandon the ideal, which 'should present a continuing but not hopeless challenge'.

\section{References}

Azavedo, M. (1995), 'Ethnicity and Democratization: Cameroon and Gabon', in Glickman H. (ed.) Ethnic Conflict and Democratization in Africa. Atlanta: African Studies Association Press.

Birch, A.H. (1972), Representation. Basingstoke: Macmillan.

Bratton, M. and N. Van de Walle (1997), Democratic Experiments in Africa. Cambridge: Cambridge University Press.

Burnell, P. (2001), 'The Party System and Party Politics in Zambia: Continuities Past, Present and Future', African Affairs 100, pp. 239-263.

Callaghy, T.M. (1994), 'Civil Society, Democracy and Economic Change in Africa', in Harbeson, J. et al. (eds) Civil Society and the State in Africa. Boulder: Lynne Rienner, pp. 231-253.

Chabal, P. and J.-P. Daloz (1999), Africa Works. Oxford: James Currey.

Chandra, K. and D. Metz (2002), 'A New Cross-National Database of Ethnic Parties', paper presented to annual meeting of MidWest Political Science Association, April 24-27.

Doherty, I. (2001), 'Democracy Out of Balance: Civil Society Can't Replace Political Parties', Policy Review, April/May, pp. 25-35.

Fomunyoh, C. (2001), 'Democratization in Fits and Starts', Journal of Democracy 12: 3, pp. 36-50.

Friedman, S. (1999), 'No easy stroll to dominance: party dominance, opposition and civil society in South Africa', in Giliomee, H. and C. Simkins (eds) The Awkward Embrace. Amsterdam: Harwood Academic Publishers, pp. 97-126.

Geisler, G. (1995), 'Troubled sisterhood: women and politics in Southern Africa. Case studies from Zambia, Zimbabwe and Botswana', African Affairs 94, pp. $545-578$.

Geisler, G. (2000), "Parliament is another terrain of struggle” : women, men and politics in South Africa', Journal of Modern African Studies 38:4, pp. 605-630.

Goetz, A.M. and S. Hassim (2001), 'In and against the Party: Women's Representation and Constituency-Building in Uganda and South Africa', UNRISD Programme Paper. 
Gunther, R. and L. Diamond (2003), 'Species of Political Parties: A New Typology', Party Politics, 9, pp. 167-199.

Gyimah-Boadi, E. (1997), Civil Society in Africa' in Diamond, L. et al. (eds) Consolidating the Third Wave Democracies: Themes and Perspectives. Baltimore: John Hopkins University Press.

Habib, A. and R. Taylor (2001), 'Political Alliances and Parliamentary Opposition Post-Apartheid South Africa', Democratization 8: 1, pp. 207-226.

Kasfir, N. (1998), 'Introduction', in Kasfir, N. (ed.) special issue on 'Civil Society and Democracy in Africa', Commonwealth and Comparative Politics 36: 2, pp. 1-20.

Kaspin, D. (1995), 'The Politics of Ethnicity in Malawi's Democratic Transition', Journal of Modern African Studies 33: 4, pp. 595-620.

Kelsall, T. (2003), 'New Political Struggles and Democracy in Mainland Tanzania', Commonwealth and Comparative Politics 41: 2, pp. 55-82.

Laakso, M. and R. Taagepera (1979), 'Effective Number of Parties: A Measure with Application to Western Europe’, Comparative Political Studies 12, pp. 3-27.

Lanegran, K. (1995), 'South Africa’s Civic Association Movement: ANC's Ally or Society's Watchdog? Shifting Social Movement - Political Party Relations', African Studies Review 38: 2, pp. 101-126.

Lawson, L. (1999), 'External Democracy Promotion in Africa: Another False Start?', Commonwealth and Comparative Politics 37: 1, pp. 1-30.

Lodge, T. (2001), 'The Namibian Elections of 1999', Democratization 8: 2, pp. 191-230.

McKinley, D.T. (2001), 'Democracy, Power and Patronage: Debate and Opposition within the African National Congress and the Tripartite Alliance since 1994', Democratization 8: 1, pp. 183-206.

Muigai, G. (1995), 'Ethnicity and the Renewal of Competitive Politics in Kenya' in Glickman, H. (ed.) Ethnic Conflict and Democratization in Africa. Atlanta: African Studies Association Press.

Nugent, P. (2001), 'Winners, Losers and Also Rans: Money, Moral Authority and Voting Patterns in the Ghana 2000 Elections', African Affairs 100, pp. $405-428$.

Olukoshi, A.O. (1998), 'Economic Crisis, Multipartyism and Opposition Politics', in Olukoshi, A.O. (ed.) The Politics of Opposition in Contemporary Africa. Uppsala: Nordiska Afrikainstitutet, pp. 8-38.

Oluoch, F. (2002), 'Is Kenya's Opposition Too Broke to Party?' in The Nation on the Web, May 27, 2002, accessed via www.nationaudio.com.

Osei-Hwedie, B. (1998), 'The Role of Ethnicity in Multi-Party Politics in Malawi and Zambia', Journal of Contemporary African Studies 16: 2, pp. 227-247.

Ottaway, M. (1999), 'Ethnic Politics in Africa: Change and Continuity', in Joseph, R. (ed.) State, Conflict and Democracy in Africa. Boulder: Lynne Rienner, pp. 299-317.

Ottaway, M. (2004), 'Civil Society', in Burnell, P. and V. Randall (eds) Politics in the Developing World. Oxford: Oxford University Press.

Phillips, A. (1995), The Politics of Presence. Oxford: Oxford University Press. 
Pitkin, H. (1967), The Concept of Representation. Berkely: California University Press.

Pringle, R. and S. Watson (1998), “'Women's Interests” and the Poststructuralist State', in Phillips, A. (ed.) Feminism and Politics. Oxford: Oxford University Press.

Randall, V. and L. Svåsand (2002), 'Political Parties and Democratic Consolidation in Africa', Democratization 9: 3, pp. 30-52.

Salih, M.M.E. (2003), 'Conclusions', in Salih, M.M.E. (ed.) African Political Parties. London: Pluto pp 348-357.

Sartori, G. (1976), Parties and Party Systems. Cambridge: Cambridge University Press.

Scarritt, J.R. and S. Mozaffar (2002), 'Ethnopolitical Cleavages and the Predominance of Multiethnic Parties in Africa: A Theory Illustrated by the Case of Zambia', unpublished paper.

Sithole, M. (1995), 'Ethnicity and Democratization in Zimbabwe: From Confrontation to Accommodation', in Glickman, H. (ed.) Ethnic Conflict and Democratization in Africa. Atlanta: African Studies Association Press, pp. 121-160.

Squires, J. (1996), 'Quotas for Women: Fair Representation?', Parliamentary Affairs 49:1, pp. 71-88.

Tripp, A.M. (2000), Women and Politics in Uganda. Oxford: James Currey.

Van de Walle, N. (2003), 'Presidentialism and Clientelism in Africa's Emerging Party Systems', Journal of Modern African Studies 41:2, pp. 297-321.

Van de Walle, N. and K.S. Butler (1999), 'Political Parties and Party Systems in Africa's Illiberal Democracies', Cambridge Review of International Affairs 13:1, pp. 14-28.

Van Walraven, K. (2000), 'Of Canvassing and Carnival: Some Reflections on the Political Economy and Culture of Democratic Politics in Africa', paper presented at the 43rd Annual Meeting of the African Studies Association, Nashville Tennessee, 18 November.

Vincent, L. (2001), 'A Question of Interest: Women as Opposition', Democratisation $8: 1$, pp. 69-84.

Vincent, L. (2002), 'Beyond the Numbers: Do Quotas for Women Count?', unpublished paper presented to UK Political Studies Association Women's Group Conference, February.

Wanjohi, N.G. (2003), 'Sustainability of Political Parties in Kenya', in Salih, M.M.E. (ed.) African Political Parties. London: Pluto, pp. 239-256.

Waylen, G. (1994), 'Women and Democratisation: Conceptualising Gender Relations in Transition Politics', World Politics 46, pp. 327-354.

Widner, J.A. (1997), 'Political Parties and Civil Societies in Sub-Saharan Africa', in Ottaway, M. (ed.) Democracy in Africa: The Hard Road Ahead. Boulder: Lynne Rienner, pp. 65-81.

Young, C. (1999), 'The Third Wave of Democratization in Africa', in Joseph, R. (ed.) State, Conflict and Democracy in Africa. Boulder: Lynne Rienner, pp. 15-38.

Yoon, M.Y. (2001), 'Democratization and Women's Legislative Representation in SubSaharan Africa', Democratization 8:2, pp. 169-190. 


\title{
Do Party Systems Matter for Democracy? A Comparative Study of 28 Sub-Saharan Countries
}

\author{
Matthias Basedau
}

\section{Introduction}

The third wave of democratisation in sub-Saharan Africa that began more than a decade ago has undoubtedly produced mixed results. However, given that political parties and party systems are an indispensable part of liberal democracy (Lipset 2000) it is surprising how little empirical research has been done on the link between political parties, party systems and the success or failure of democracy in sub-Saharan Africa. In recent years only political parties and party systems in Africa have been attracting growing interest. ${ }^{1}$ Two empirical studies stress the link between party systems and democracy. Yet, the study by Karvonen and Anckar (2002), who include 31 African cases in a sample of 99 'Third World' countries, concludes that party system characteristics have overall 'limited explanatory value' for democratisation (Karvonen and Anckar 2002: 11). It was not before mid 2005 that a study on the link between party systems and democracy in Africa was published (Kuenzi and Lambright 2005) which found a positive relationship between the two phenomena.

Other studies focus rather on conceptual and theoretical aspects, systematic or country case description, or the party system as a dependent variable (Basedau 2002; Mozaffar et al. 2003) than on studying empirically whether party system characteristics are systematically and theoretically plausibly linked to the democratic performance of African political systems.

This is not the result of poor theory. Theoretically, the link between parties and democracy is easily established by a functionalist approach (Bratton and Van de Walle 1997: 251; Sandbrook 1996: 75f): at the intermediary level between society and government the party system has to meet the functions of both efficiency and inclusion (for a more detailed discussion

1. Erdmann 1999; Van de Walle and Butler 1999; Randall and Svåsand 2002c; Salih 2003. 
see below). With regard to the main descriptive characteristics of a party system, one should expect in democratic party systems moderate fragmentation, high institutionalisation (Bendel and Grotz 2001) and - frequently neglected - low polarisation (Sartori 1976). Several scholars have pointed to a range of respective shortcomings in African party systems. Dominant parties 'dominate' the political systems in the region (Bogaards 2004; Van de Walle 2003). Rudimentary organisation, poor funding, breakaways of splinter parties and dominating 'Big Men' show clearly that institutionalisation is not a common feature of African parties and party systems (Erdmann 1999, 2002; Van de Walle 2003). Sharp conflict between party supporters culminate all too often in violence in election campaigns (see Laakso and Mehler in this volume).

However, all these shortcomings do not provide for an overall explanation for the relatively disappointing democratic performance of sub-Saharan Africa in general. This could be true for the aggregate but not for individual cases, especially not for relatively successful democratic performers: democratic multi-party systems should be different if party systems matter for democratisation.

The paper seeks to examine - to some extent provisionally of course - the relationship between key elements of party systems and the democratic performance of the respective countries by comparing relatively stable democratic African countries with countries that albeit practising formal multi-partyism must be looked upon as rather authoritarian or hybrid regimes. The central problematique thus is: Is there a theoretically plausible and empirically systematic connection between party system characteristics and the democratic performance in contemporary sub-Saharan Africa? As the results will show it is the frequently neglected dimension of inter-party polarisation and the combination of all elements that offer the most convincing explanation rather than fragmentation and institutionalisation.

\section{Comparative design}

As noted above, the results of the third wave in sub-Saharan Africa have been mixed. We are facing very different outcomes of the transition processes that started around 1990. Though there is still a considerable amount of fluidity, in early 2004 (and there has been no substantial change) we can roughly identify three to four major groups: up to 11 countries constitute a relatively small group of democratic success stories, albeit with uncertain prospects for consolidation. The clearly non-democratic 15 cases cut into a relatively small group of countries, which are notorious for civil strife or 
even outright state collapse, and another subgroup, which comprises quite openly and stable authoritarian regimes, while having some outward trappings of democracy. The remaining 20 countries form the biggest group of 'hybrid' regimes being trapped in the twilight of democracy and dictatorship. Whereas this provisional balance sheet might be disillusioning for a human rights and democracy enthusiast, it surely exhibits an adequate variety to serve the purpose of comparison.

The empirical situation in the region seems to be suitable for an approximate application of the method of difference outlined by John Stuart Mill (1997; Nohlen 2002). Mill advised scholars to study causes of phenomena by 'comparing instances in which the phenomenon occurs with instances in other respects similar where it does not". The logic of this procedure is appealing: Necessarily, causes have to be applicable for the positive instances and non-applicable for the negative examples. The similarity in other respects", a near ceteris paribus, minimises the potential influence of intervening variables not under investigation. Obviously, it is highly improbable to find such natural experimental settings for political phenomena.

Easing the selection criteria to some extent, Arend Lijphart (1975) and Giovanni Sartori (1994a) have adapted this approach naming their models the 'most-similar-cases strategy' and the 'comparable cases strategy' respectively. They advised studying cases that share a wide range of common features except for the variables between which a connection is hypothesized.

However, a methodological caveat remains. Although the region sub-Saharan Africa could possibly constitute a similar context - and the countries themselves could be comparable cases in Lijphart's sense - it is by no means a ceteris paribus in the strict sense or even the similarity demanded by Mill. Hence, it is possible that contextual variables are superior in explaining the diverging democratic performance. Since a comprehensive simultaneous test is beyond the scope of this paper, we must limit our comparative control to contrasting positive and negative examples. Nevertheless, if theoretically plausible common characteristics in the independent variables (here party systems) can be found with the democratic multi-party systems and this is not the case with non-democratic multi-party systems there is a relatively strong empirical support for a causal link.

Thus, we will proceed as follows by:

1. Discussing the theoretical argument and identifying the respective party system elements that might affect democratisation.

2. Identifying the current democratic and non-democratic multi-party systems in sub-Saharan-Africa. 
3. Applying measures of the key party system characteristics to the cases.

4. Evaluating whether these variables allow theoretically plausible sys tematic causal explanation for the success or failure of democracy.

\section{The theoretical argument: A functionalist approach}

Before discussing the theoretical argument we have to distinguish between political parties and party systems (Randall and Svåsand 2002c: 6f; Basedau 2002: 312). It must be stressed that a party system is more than just the sum of political parties in a given country. A system is about the relative size of and the relations between its elements. What makes several parties work as a system are the nature of the relations between the parties and the stability of interaction between them. Moreover, the party system has to be conceptualised as a subsystem of the political system. More precisely, the party system is characterised by its intermediate position between society (the population, interest and civil society groups) on the one hand and state and government on the other hand (see Figure 1).

Figure 1: Simplified model of the party system's intermediate position

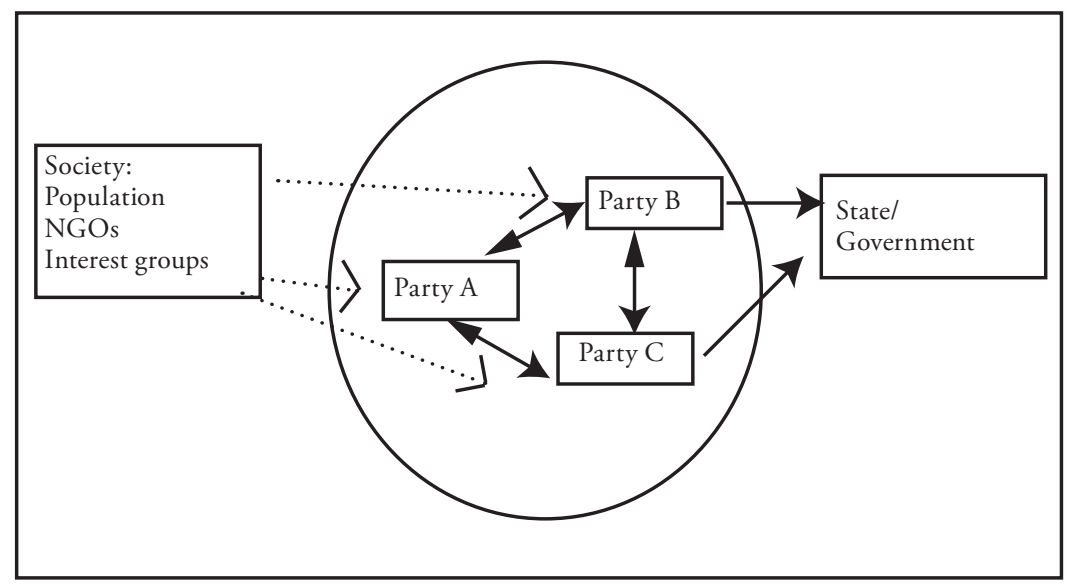

Whilst numerous functions of political parties and party systems are listed in the literature (Wiesendahl 1980; Emminghaus 2002: 290; Bogaards and Erdmann in this volume), the prime functions in a (democratic) political 
system deriving from this intermediate position can be reduced to two, namely inclusion and efficiency. ${ }^{1}$

Inclusion refers to the representation of societal groups and their demands (see Randall this volume). Strong opposition parties check governments and hold them accountable. By providing an alternative for the electorate opposition supporters, feelings of deprivation and marginalisation can be avoided.

Although strong opposition could also be attributed to the requirement of efficiency, the function of efficiency mainly refers to the party system's capacity to structure inter-party competition. Filtering and aggregating different interests are required to form stable governments that formulate and implement efficient policies. As an additional element, elite recruitment through parties is part of the efficiency function.

It becomes clear at this point that parties as single units cannot accomplish these functional requirements. Thus, the system is the suitable level to study the effects on democratisation although, of course, parties cannot be separated completely from the parties as components of the party system.

How do the functional requirements of inclusion and efficiency relate to the main descriptive characteristics of party systems? Altogether there are three major party system characteristics which cut into a number of sub-aspects. According to Sartori's classic work of 1976, party systems can be described by their levels of fragmentation (i.e. number and relative size of relevant parties). Moreover, as studies on parties and party systems in Latin America and Eastern Europe have shown, a further central characteristic of party systems is their level of institutionalisation (Mainwaring and Scully 1995; Bendel 1996). An institutionalised party system includes more than the 'mass parties' Sartori demanded for his 'structured party systems". In an abstract sense, the notion of institutionalisation is about the 'systemness' of the party system, its constituent elements (i.e. the parties) and the party system's relations to society and the political system as a whole. ${ }^{2}$

1. One could even reduce it to the function of transforming different demands into accepted government decisions.

2. It might be argued that due to unstable patterns of interaction or the marginalised role of political parties in many African countries, though there are parties, there is no party system in the strict sense. Of course, the degree of 'systemness' of interparty interaction differs from country to country. Sometimes, we observe emerging party systems rather than consolidated or institutionalised systems. However, generally, we will embark on a practical approach that uses the term 'system' relatively independently of the degree of 'systemness' or the closely related notion of institutionalisation. Only cases that do not meet minimum requirements for 'systemness' 
However, there are different concepts of institutionalisation. Differences can be identified with regard to the number of characteristics, the application to either party or party system level, the intra-system perspective versus the external relations of the system, and the integration of elements that can rather be conceptualised as being part of polarisation. ${ }^{1}$ Hence, some conceptual ambiguities remain. It is still unclear how many characteristics should be part of it and how the constituent elements are related to each other.

We define institutionalisation as a four-dimensional model (Bendel and Grotz 2001; Mainwaring and Scully 1995: 4f): a) all relevant political parties should enjoy strong and stable roots in society; b) political parties should have high levels of bureaucratic organisation and cohesion (low or moderate factionalism) as well as a sufficiently competitive and participatory mechanism of electing leaders; c) the party system should display low volatility between consecutive elections and stable patterns of competition (low floor crossing, low 'death and birth rate' of political parties); finally, d) the party system should be accepted as and actually be the key decision making forum in the political arena as a whole, being paramount to potential veto actors such as the military or powerful individuals ('Big Men' or 'political entrepreneurs').

A third characteristic of party systems has been widely neglected in party research, though already included in Sartori's classic study (Sartori 1976): the dimension of polarisation. In the Sartorian sense polarisation is in the first place about the ideological distances between the relevant parties and the respective dynamics (centripetal vs. centrifugal). Though it can be argued that ideological differences are not relevant in the African context (Van de Walle 2003, see below), polarisation has a behavioural dimension which is principally independent from ideology. Inter-party relations can be characterised by co-operation or confrontation.

(elections) will be excluded from observation. This approach enables us to treat the degree of 'systemness"/institutionalisation as an independent variable or potential cause for the success or failure of democracy.

1. Randall and Svåsand 2002c; Bendel and Grotz 2001; Nohlen 2003: 69; Mainwaring and Scully 1995: $4 \mathrm{f}$. 
Table 1: Party system characteristics and democracy

\begin{tabular}{|c|c|c|c|c|}
\hline \multicolumn{2}{|c|}{ Party system characteristic } & \multirow{2}{*}{$\begin{array}{l}\text { Most favourable } \\
\text { for democracy } \\
\text { Moderate }\end{array}$} & \multirow{2}{*}{$\begin{array}{l}\begin{array}{l}\text { Least favourable } \\
\text { for democracy }\end{array} \\
\text { Very high or } \\
\text { Very low }\end{array}$} & \multirow{2}{*}{$\begin{array}{l}\text { Main function } \\
\text { concerned } \\
\text { Efficiency and } \\
\text { Inclusion }\end{array}$} \\
\hline Fragmentation & $\begin{array}{l}\text { Number and } \\
\text { relative size of } \\
\text { relevant parties }\end{array}$ & & & \\
\hline \multirow{4}{*}{$\begin{array}{l}\text { Institution- } \\
\text { alisation }\end{array}$} & Roots in society & Strong & Weak & Inclusion \\
\hline & $\begin{array}{l}\text { Stability of } \\
\text { inter-party } \\
\text { competition }\end{array}$ & High & $\begin{array}{l}\text { Low } \\
\text { Volatile }\end{array}$ & Efficiency \\
\hline & $\begin{array}{l}\text { Bureaucratic } \\
\text { organisation of } \\
\text { political parties }\end{array}$ & Strong & Weak & Efficiency \\
\hline & $\begin{array}{l}\text { Legitimate } \\
\text { main forum in } \\
\text { political system }\end{array}$ & Uncontested & Marginalised & Efficiency \\
\hline \multirow[t]{2}{*}{ Polarisation } & $\begin{array}{l}\text { Ideological } \\
\text { distance and } \\
\text { dynamics }\end{array}$ & $\begin{array}{l}\text { Low to } \\
\text { moderate } \\
\text { Centripetal }\end{array}$ & $\begin{array}{l}\text { High } \\
\text { Centrifugal }\end{array}$ & $\begin{array}{l}\text { Efficiency and } \\
\text { Inclusion }\end{array}$ \\
\hline & $\begin{array}{l}\text { Mode of } \\
\text { inter-party } \\
\text { competition }\end{array}$ & Co-operative & $\begin{array}{l}\text { Confron- } \\
\text { tational }\end{array}$ & Efficiency \\
\hline
\end{tabular}

These three key characteristics can easily be related to the functions of inclusion and efficiency as discussed above (for an overview see Table 1). As for (low) fragmentation, having few parties is favourable to forming governments and thus to permitting efficiency whereas high fragmentation tends to hinder stable government. However, the dominance of one party can give way to authoritarian practices when government is not checked by strong opposition parties. In the functional logic, moderate party fragmentation as in two-party systems or moderate multi-party systems is most favourable because it neither hinders government efficiency nor marginalises opposition (Sandbrook 1996: 75f; Bratton and Van de Walle 1997: 251). High institutionalisation is primarily about efficiency: while strong roots of the individual parties in (civil) society - reflected on the system level by stable cleavages - favour inclusion, quite strong organisational structures and cohesion, low volatility and stable inter-party competition patterns help establish a party system that enjoys the acceptance and the real position of an undisputed main forum in the political decision-making process. Finally, moderate ideological differences between the political parties help secure real programmatic alternatives, and co-operation instead of confrontation 
in the party system is highly favourable for policy decision-making, implementation and acceptance.

Without doubt, the model of a moderately fragmented, low polarised, and highly institutionalised party system seems to be rather idealistic - or even unrealistic - when being applied to sub-Saharan Africa. We have already pointed to a range of respective shortcomings in African party systems such as one-party dominance (Bogaards 2004; Van de Walle 2003), sharp conflict between parties (Monga 1997; Laakso and Mehler in this volume) and low levels of institutionalisation (Van de Walle 2003; Erdmann 1999; 2002; Fomunyoh 2001: 47f). However, we have to emphasise again that all these shortcomings do not provide for an over-all explanation for the relatively disappointing democratic performance of sub-Saharan Africa in general. This could be true for the aggregate but not for individual cases, especially not for relatively successful democratic performers. Hence, we have to identify the diverging levels of democratisation.

\section{Identifying democratic and non-democratic multi-party systems in sub-Saharan Africa}

\subsection{Exclusion of cases}

Not all cases can be included in our study. First of all, we have to exclude all cases that held no multi-party elections or no elections at all between 1990 and 2004. This applies to Eritrea, Somalia and DRC (no elections at all) and Uganda, Swaziland, Sudan (elections but no multi-party competition). Moreover, we decided to choose only cases where at least two legislative elections have taken place since 1990 until the end of 2004. Cases such as Angola, Burundi, Liberia and Rwanda with only one legislative election do not provide the minimum requirements for a sound data base. Also, it is questionable whether we can assume that there is a party system at all given that the elections were more than ten years ago (Angola) or were held only very recently (Rwanda).

Furthermore, we avoided the inclusion of cases with very recent and substantial changes $v i s-\grave{a}-v i s$ the democratic or authoritarian character of their regimes; a minimum of continuity in this respect should guarantee results.

Finally, in order to guarantee conceptual clarity and avoid conceptual stretching and confusion (Sartori 1991; 1994a) we decided to exclude 'disputed' cases that have come close to being democratic or 'free' in the last 
ten to 15 years without meeting the minimum requirements fully. This is also a response to criticism on democracy indices (see below).

\subsection{Democratic multi-party systems}

Before identifying democratic multi-party systems one must have a clearcut notion or concept of democracy. Much has been said and written about concepts and types of democracy and we do not intend to add another one. We opt for a liberal notion of democracy, particularly for Robert A. Dahl's classic concept of 'polyarchy' $(1971 ; 1998)$. A polyarchy is a political system that is characterised by high levels of competition and participation in the political system.

A profound criticism questions whether liberal democracy can be applied to Africa. In fact, there is no compelling argument to use a different concept given that the relevant discussion (see Ake 1996, Basedau 2003: 41-48) has failed to prove that liberal democracy is generally incompatible with African culture. To make matters worse, 'African democracy' has often been misused as a pretext to legitimise tyranny. Finally, when we keep in mind that no assessments are available which are based on different concepts and cover the whole continent there is no credible alternative to a liberal concept of democracy in this study.

Narrower criticism on the concept of polyarchy focuses inter alia on the need for the rule of law and exclusive decision-making power by the elected officials (Merkel 1999; Schmitter and Karl 1991). This problem can be minimised by using the Freedom House $(\mathrm{FH})$ ratings as a starting point for operationalisation, where these aspects are included. As democracies we provisionally define those African countries that were rated 'free' in the study of 2003-2004.

In order to ensure the certain democratic stability demanded above leaving aside consolidation of democracy - we limit the selection of countries to those that have been democratic or 'free'for the previous nine years - which is roughly the period that embraces two legislative periods and three legislative elections ( with countries thus being in their 10th year of democracy). This is also a response to criticism on the $\mathrm{FH}$ ratings (Basedau 2003: 58-60; Schmidt 1995: 281). Given the subjectivity of the assessments - and a possible US bias - we believe that indices adequately show tendencies but might be less precise with regard to the exact values, we 
demand cases to have political developments that point in an undisputed direction. ${ }^{1}$

Table 2: Sub-Saharan democratic multi-party systems in 2003-2004

\begin{tabular}{llccc}
\hline Country & Duration & $\begin{array}{l}\text { Freedom House ratings } 2003-2004 \\
\text { (1 indicates maximum; } \\
\text { minimum of 'freedom") }\end{array}$ & $\begin{array}{l}\text { Combined Free- } \\
\text { dom House rat- } \\
\text { ings on average } \\
1990-2003\end{array}$ \\
\hline Fenin & Free since & Political rights & Civil liberties & \\
Botswana & $1991-92(\mathrm{PF})$ & 2 & 2 & 2.5 \\
Cape Verde & $1991-94(\mathrm{PF})$ & 2 & 2 & 2.0 \\
Ghana $^{*}$ & $2000-01(\mathrm{PF})$ & 1 & 1 & 1.8 \\
Lesotho* $^{*}$ & $2002-03(\mathrm{PF})$ & 2 & 2 & 3.7 \\
Mali & $1995-96(\mathrm{PF})$ & 2 & 3 & 4.0 \\
Mauritius & $1981-82(\mathrm{PF})$ & 1 & 2 & 3.0 \\
Namibia & $1990-91(\mathrm{PF})$ & 2 & 2 & 1.6 \\
Sao Tomé \& & $1991-92(\mathrm{PF})$ & 2 & 3 & 2.5 \\
Principe & & & 2 & 1.9 \\
Senegal* & $2002-03(\mathrm{PF})$ & 2 & 3 & 3.7 \\
South Africa & $1994-95(\mathrm{PF})$ & 1 & 2 & 2.4 \\
\hline
\end{tabular}

${ }^{*}$ Excluded from sample due to short democratic experience (italics). In brackets status before $(\mathrm{F}=$ Free, $\mathrm{PF}=$ Partly Free, $\mathrm{NF}=$ Not Free $)$

As shown in Table 2, eleven out of 48 sub-Saharan countries were 'free' in 2003-2004. However, Senegal and Lesotho receive only for the second time a 'free' rating and thus are excluded. In Ghana too democratic experience (since 2000-2001) has been too short to be included in the study. The remaining cases form group 1 of the sample.

\subsection{Identifying non-democratic multi-party systems in Sub-Saharan Africa}

There are several ways to identify country cases that have practised multiparty systems since the 1990s but fall short of being democratic. We have already excluded cases that have held no or only one legislative elections since 1990 because these countries do not meet minimum requirements in

1. This is not to say that party system characteristics are generally irrelevant in explaining the democratic or non-democratic performance of all these cases. It is merely methodological caution to exclude them. 
terms of a sufficient data base. Secondly, countries that have made substantial steps towards democracy recently or have scored quite close to being 'free' (i.e. combined FH 2003-2004 score 3,5 or better; average FH ratings since 1990 between 3 and 4) during the last decade without permanently crossing the line must be excluded as well in order to guarantee a sufficient conceptual difference between democratic and non-democratic multi-party systems. Examples of the latter are Malawi, Mozambique, the Seychelles and Tanzania, instances of the former are Kenya (political transfer of power in 2002) and Guinea-Bissau (return to electoral regime in 2004 after coup). One could include the cases of Ghana, Lesotho, and Senegal too, which were excluded as democratic multi-party systems due to the short democratic period of time.

The remaining cases can be divided into two groups (Table 3): a group that comprises 'not free' cases and a group that is composed of 'partly free' cases that have had combined FH ratings of 4 or below on average for several years or at least have seen a sharp decline recently. Taken together the cases form the control group of the non-democratic multi party systems (group 2) of the sample (Table 3).

\section{Measuring party system characteristics}

First of all it must be stressed that we intend to measure party systems and not single elections and their respective outcomes on the party systems (for a different view see Mozaffar et al. 2003: 384f). Because we want to look at the longer lasting features, each country case will be used as an analytical unit. Thus, we will instead measure (average) indicators of all consecutive multi-party elections - in the cases where data are available - in all of the countries that qualified for observation.

Furthermore, because we have not selected our countries according to the principle of maximising the sample magnitude but as a result of their conceptual quality, the sample compromises only 28 cases. Since this number does not seem perfectly suitable for a pronounced quantitative strategy - and we want to keep the individual cases identifiable - we will combine a macro-qualitative logic with the use of quantitative and qualitative indicators for the party system characteristics in question.

There is a multitude of opportunities to measure party system characteristics, both in quantitative and qualitative ways. Yet, the situation differs with regard to the different characteristics of party systems. Whereas we have a few difficulties in testing the degree of fragmentation, any effort to 
Table 3: Sub-Saharan non-democratic multi-party systems in 2003-04

\begin{tabular}{|c|c|c|c|c|}
\hline \multirow[t]{2}{*}{ Country } & \multirow{2}{*}{$\begin{array}{l}\text { Duration } \\
\text { Not free since }\end{array}$} & \multicolumn{2}{|c|}{$\begin{array}{l}\text { Freedom House ratings } 2003-2004 \\
(1 \text { indicates maximum; } 7 \\
\text { minimum of 'freedom") }\end{array}$} & \multirow[t]{2}{*}{$\begin{array}{l}\text { Freedom House } \\
\text { ratings on aver- } \\
\text { age 1990-2003 }\end{array}$} \\
\hline & & Political Rights & Civil Liberties & \\
\hline Cameroon & $1976-1977(\mathrm{PF})$ & 6 & 6 & 6 \\
\hline CAR & 2003-2004 (PF) & 7 & 5 & 4,4 \\
\hline Chad & $1972-1973$ & 6 & 5 & 5,6 \\
\hline Côte d'Ivoire & 2002-2003 (PF) & 6 & 5 & 5,3 \\
\hline $\begin{array}{l}\text { Equatorial } \\
\text { Guinea }\end{array}$ & $1972-1973$ & 7 & 6 & 6,8 \\
\hline Guinea & $1992-1993(\mathrm{PF})$ & 6 & 5 & 5,5 \\
\hline Mauritania & 2003-2004 (PF) & 6 & 5 & 5,9 \\
\hline Togo & 2002-2004 (PF) & 6 & 5 & 5,5 \\
\hline \multirow[t]{2}{*}{ Zimbabwe } & 2001-2002 (PF) & 6 & 6 & 5,2 \\
\hline & Partly free since & & & \\
\hline Burkina Faso & 1992-1993 (NF) & 4 & 4 & 4,5 \\
\hline Comoros & 1990-1991 (NF) & 5 & 4 & 4,3 \\
\hline Congo & 2001-2001 (NF) & 5 & 4 & 4,8 \\
\hline Djibouti & 1998-1999 (NF) & 5 & 5 & 5,3 \\
\hline Ethiopia & $1994-1995(\mathrm{PF})$ & 5 & 5 & 5,1 \\
\hline Gabon & 1990-1991 (NF) & 5 & 4 & 4,4 \\
\hline Gambia & 2001-2002 (NF) & 4 & 4 & 4,6 \\
\hline Niger & 1999-2000 (NF) & 4 & 4 & 4,7 \\
\hline Nigeria & 1997-1998 (NF) & 4 & 4 & 5,1 \\
\hline Sierra Leone & 1997-1998 (NF) & 4 & 3 & 5,1 \\
\hline Zambia & 1992-1993 (F) & 4 & 4 & 4 \\
\hline
\end{tabular}

In brackets status before $(\mathrm{F}=$ Free, $\mathrm{PF}=$ Partly Free, $\mathrm{NF}=$ Not Free) if applicable (any change since 1972/73).

\subsection{Fragmentation}

As already noted, we expect democratic multi-party systems to be moderately fragmented in order to ensure both stable government and relatively strong opposition. Although there is no lack of ways of measuring fragmentation, different quantitative indices (Taagepera and Grofman 2004; Bogaards 2004) and rather qualitative assessments such as the 'intelligent counting' by Sartori (Bogaards 2004) highlight different characteristics.

The most popular index in political science, the number of effective parties developed by Laakso and Taagepera (1979), has its merits but also displays some serious disadvantages. Most prominent is the criticism that 
the very same index-values can disguise very different actual constellations in the party system. ${ }^{1}$

Moreover, sometimes a number of parties hide in fact behind one party. Political parties such as South Africa's ANC (African National Congress) and Ethiopia's EPRDF (Ethiopian People's Revolutionary Democratic Front) are in fact congresses of several groupings, if not proper parties. Measuring fragmentation is therefore sometimes trickier than assumed at first sight.

We applied most of the measures to our sample but will present only the more significant results. In order to avoid the aforementioned problems we tried to keep our measurement as close as possible to the theoretical argument.

Hence, the operational concept of 'moderate fragmentation' deserves brief discussion. We assume moderate fragmentation excludes one-party dominance and marginalisation of opposition (either in terms of weak or highly fragmented representation of opposition parties in the legislature). Yet, problematic fragmentation in the party system is not limited to exclusion and marginalisation. Another form immoderate fragmentation can take is when extreme pluralism in the party system hinders the formation of stable governments.

As dominant party systems ${ }^{2}$ we define those systems where one and the same party has won the last two subsequent elections with at least 50 per cent of the seats (in the lower chamber). If there is a directly elected chief executive or president, this post should be held by the dominant party (Bogaards 2004). A peaceful transfer in legislative elections is an indicator for non-dominance. Because one party dominance can vary from 51-99 per cent we employ an extra measure for high levels of dominance. We consider it 'super"-dominance if at least in the last two succeeding elections

1. This might be illustrated by a few examples: for instance, a value of 3.3 can even hide an absolute majority or one party dominance. In Burkina Faso in 2001, the dominant party, the CDP, gained $51.4 \%$ of the seats, and altogether 13 parties were represented in the National Assembly. Niger, in 1999, had the identical value of 3.3. Here, there was no absolute majority and only five parties managed to win seats in parliament. Ghana in 2000 showed 2.2 effective parties, thus reflecting the approximate two-party system with the two major parties having a seat share of 50 and 46\% respectively. However, in Mali in 1992, 2.2 effective parties hid a dominant party with $65.5 \%$ seat share and nine small parties (biggest: $7.8 \%$ seat share). For further examples see Bogaards (2004).

2. We did not use Sartori's general and Africa-specific typologies because they include the democratic performance. Predominant and hegemonic party systems differ only in this regard (Sartori 1976: 192ff; 261). 
one and the same ruling party holds more than two thirds of the seats. This seems to be a reasonable cut-off point because it is frequently the threshold for changing the constitution.

Dominance means marginalisation of opposition but opposition can be weak regardless of dominance or transfers of power. Hence, we acknowledge another form of opposition marginalisation. When the biggest opposition party holds less than 25 per cent of the seats, or even less than 10 per cent, we consider opposition to be weak or very weak respectively.

As high fragmentation or extreme pluralism we define those systems that have on average five or more effective parties and in each election at least 4.0 effective parties. In addition at least 10 parties should be consistently represented in parliament.

Consequently, moderate fragmentation describes those party systems that do not fall under one of the aforementioned categories. There are two classes of them: in 'two-party systems' two major parties alternate in gaining absolute majorities and in 'moderate pluralism' no single party gains an absolute majority and government is formed by a coalition. It can be distinguished from extreme pluralism by the fewer effective parties and the lower actual number of parties in parliament $(<10)$.

We have constructed a Moderate Fragmentation Index (MFI) by assigning and adding values to the characteristics discussed above. We specified in some aspects. First, all elections are covered but MFI-values are calculated per election (that is total scores are divided by the number of elections, see Appendix I). For marginalisation, we used exclusively the seat share of the biggest opposition party (commonly the runner-up) and divided into three categories $(>25 \% ;<25 \% ;>10 \%)$. It is calculated independently of any transfer of power or the exact share of the winning party because fragmented or weak opposition is a liability in itself, and the degree of dominance is covered by the other elements of the index (see Appendix I). To illustrate the logic of the index, an overall maximum value of 4 definitely shows immoderate fragmentation. Consistently, the biggest opposition parties have less than 10 per cent of the seat share and either dominance exceeds two thirds majorities or fragmentation is as high as at least five effective parties. Thus, on the index both the 'dominant party-satellite parties' type described by Van de Walle (2003) and the chaotic 'pulverised"-type will score high. In turn, two-party and moderate pluralism systems will score best.

How do the cases relate to our different measurements? As shown in Table 4, we have almost all kinds of fragmentation in our sample, albeit highly diverging with regard to frequency: most prominent are, as expect- 
ed, dominant party systems (17 cases). Djibouti constitutes a special case because the ruling party, several times renamed and to some extent rather a coalition in essence, has been winning 100 per cent of the seats. There is only one (nearly) two-party system (Cape Verde), only two cases of extreme pluralism (Benin, Congo-Brazzaville) and seven cases of moderate pluralism. Yet, moderation can mean very different constellations: in Mali, Côte d'Ivoire, Niger, and Sao Tomé the second previous elections returned an absolute majority. The same applies to Sierra Leone in 2002. In the islands of Mauritius and the Comoros the previous elections (before the end of 2004) always meant, albeit for different parties or alliances, a landslide victory for the winning parties/alliances and devastating defeat for the losers. It is only CAR where there was never an absolute majority (and no extreme pluralism).

Table 4: Party system fragmentation and democracy (last two elections)

\begin{tabular}{|c|c|c|c|}
\hline & Free & Partly free & Not free \\
\hline $\begin{array}{l}\text { Two-party or } \\
\text { moderate pluralism }\end{array}$ & $\begin{array}{l}\text { Cape Verde* } \\
\text { Mali* } \\
\text { Mauritius* } \\
\text { Sao Tomé }\end{array}$ & $\begin{array}{l}\text { Comoros* } \\
\text { Niger* } \\
\text { Sierra Leone* }\end{array}$ & $\begin{array}{l}\text { CAR } \\
\text { Côte d'Ivoire* }\end{array}$ \\
\hline Extreme pluralism & Benin & Congo-Brazzaville & \\
\hline Dominant party & $\begin{array}{l}\text { Botswana } \\
\text { Namibia } \\
\text { South Africa }\end{array}$ & $\begin{array}{l}\text { Burkina Faso } \\
\text { Djibouti } \\
\text { Ethiopia } \\
\text { Gabon } \\
\text { Gambia } \\
\text { Zambia** } \\
\text { Nigeria }\end{array}$ & $\begin{array}{l}\text { Chad } \\
\text { Cameroon } \\
\text { Equatorial-Guinea } \\
\text { Guinea } \\
\text { Mauritania } \\
\text { Togo } \\
\text { Zimbabwe }\end{array}$ \\
\hline Deviant cases & 4 & 3 & 2 \\
\hline
\end{tabular}

* Absolute majorities in one election only or in both elections but not the same parties/ alliances.

** In Zambia the ruling party managed to gain an absolute majority shortly after the elections by co-opting independent MPs and winning by-elections.

However, as for causal relationships, moderate fragmentation in the more qualitative sense is clearly of limited explanatory value. Nine cases deviate from the theoretical expectation. Amongst the exceptions are three dominant but democratic multi-party systems (Botswana, South Africa and $\mathrm{Na}$ mibia) ${ }^{1}$ and one extremely fragmented but also democratic case (Benin).

1. In the Sartorian sense, these cases have predominant or dominant-non-authoritarian party systems. 
This result is even less impressive than a special test for one-party dominance revealing eight cases that cannot be explained by the hypothesis that dominance hinders democracy. Testing marginalisation could check whether the degree of dominance might be less severe with the democratic party systems. This is not the case. Although the number of deviating democratic cases is reduced to three, it is highly fragmented Benin that is now in line with expectation. More worrying, the number of exceptions rises to ten.

The MFI values return somewhat better results (see Table 5). Though we discover altogether seven deviating non-democratic cases with values above average, the number of unexplained democratic cases is reduced to two, namely Benin and Botswana. Namibia and South Africa advance to be compatible with theory because the index gives credit to the fact that the (later on) dominant parties' victories in founding elections meant a transfer of power.

Table 5: Moderation of party system fragmentation and democracy

\begin{tabular}{|c|c|c|c|}
\hline \multirow[b]{2}{*}{ MFI score } & \multirow{2}{*}{$\begin{array}{l}\text { Democratic } \\
\text { Free }\end{array}$} & \multicolumn{2}{|c|}{ Non-democratic } \\
\hline & & Partly free & Not free \\
\hline $\begin{array}{l}\text { Below } \\
\text { average }(<2,5)\end{array}$ & $\begin{array}{l}\text { Cape Verde } \\
\text { Mali } \\
\text { Mauritius } \\
\text { Namibia } \\
\text { Sao Tomé } \\
\text { South Africa }\end{array}$ & $\begin{array}{l}\text { Niger } \\
\text { Nigeria } \\
\text { Sierra Leone } \\
\text { Zambia }\end{array}$ & $\begin{array}{l}\text { Cameroon } \\
\text { CAR } \\
\text { Zimbabwe }\end{array}$ \\
\hline $\begin{array}{l}\text { Above } \\
\text { average }(>2,5)\end{array}$ & $\begin{array}{l}\text { Benin } \\
\text { Botswana }\end{array}$ & $\begin{array}{l}\text { Burkina Faso } \\
\text { Comoros } \\
\text { Congo } \\
\text { Djbouti } \\
\text { Gabon } \\
\text { Gambia }\end{array}$ & $\begin{array}{l}\text { Chad } \\
\text { Côte d'Ivoire } \\
\text { Equatorial Gui- } \\
\text { nea, Ethiopia } \\
\text { Guinea } \\
\text { Mauritania } \\
\text { Togo }\end{array}$ \\
\hline Deviant cases & 2 & 4 & 3 \\
\hline
\end{tabular}

High MFI scores indicate marginalisation of opposition and either one-party dominance or high fragmentation.

This might suggest that one-party dominance turns out to be problematic when the dominant party in question is a former unity party from the authoritarian period. In fact, cases such as Cameroon, Burkina Faso, Equatorial Guinea, Gabon, Guinea, Mauritania and Togo fit into this category. ${ }^{1}$

1. In the Sartorian sense, these cases form a group of hegemonic or dominant-authoritarian cases. 
However, others do not: Ethiopia and Gambia are clearly non-democratic but both ruling parties were created in 1989 and 1997 respectively. In Djibouti the several times renamed super-dominant party was also founded after 1990. In Zambia and Zimbabwe formerly democratic dominant parties lapsed into authoritarian practices. In Nigeria, Obasanjo's Progressive Democratic Party (PDP) - founded only in 1998 - is not (yet) the classic hegemonic party.

Independently of the measures applied, ${ }^{1}$ we must concede that fragmentation is not a very good predictor for democracy. Dictatorship and authoritarian tendencies might come about through one-party dominance - though this could reflect rather than cause autocracy - or through high fragmentation. Yet, it is also possible that the outcome will be democratic. According to our data, at best there might be a slight tendency that moderate fragmentation helps democracy to flourish.

\subsection{Institutionalisation}

Commonly, institutionalisation is measured by volatility according to the well-known Pedersen Index (1983; i.e. the accumulated sum of differences of how parties perform within two succeeding elections). However, the index has some disadvantages, especially because only minimum changes in voting behaviour are measured. ${ }^{2}$ More importantly, as already discussed, institutionalisation involves various additional elements, volatility being rather an indicator for one of these elements, namely the stability or regularity of inter-party competition and possibly of how strong the parties' roots in society are.

A more sophisticated way to measure institutionalisation has been tried by Mainwaring and Scully (1995) in their work on Latin American party systems. Contrasting 'institutionalised' and 'inchoate' party systems they add to volatility the average party age as a measure for whether parties have

1. We have furthermore tested the following variables (in brackets: operationalisation): inclusiveness of government (coalition government, including voluntary coalition, number of effective ruling parties/number of effective opposition parties), effective parties (seats: Laakso/Taagepera 1979), degree of dominance (winning share, runner-up share, winning margin), number of parties represented in parliament. All hypotheses proved to be insignificant and had to be rejected.

2. To name the most obvious: changes in voting behaviour possibly disappear in the aggregate. A continued share of 20 per cent for instance does not necessarily mean that the same persons were actually the voters. Moreover changes in the turnout are not taken into account. High volatilities can sometimes reflect election boycott rather than changes in voting behaviour. 
'stable roots in society". The adaptation of Mainwaring's and Scully's operationalisation to 30 African countries by Kuenzi and Lambright (2001) involves even more dimensions of institutionalisation. They add (when possible) the volatility between parliamentary and presidential elections and introduce - in addition to electoral regularity (volatility) and stable roots in society (party age) - a third criterion they call interchangeably 'institutionalisation' or 'acceptance of parties and elections". Kuenzi and Lambright use as indicators losers' acceptance of results, the prevalence of electoral boycott and the competitiveness of elections. Though these might be a promising way to measure whether electoral competition of parties is accepted and legitimate in the political arena, it is doubtful whether we can employ them as measures for institutionalisation in our study: whereas we regard both boycott and losers' acceptance rather as indicators of inter-party polarisation, ${ }^{1}$ their third indicator for 'acceptance", 'free and fair elections", cannot be used to measure the link between party systems and democracy because free and fair elections are a necessary condition for democracy (see below). ${ }^{2}$ Consequently, Kuenzi and Lambright (2005) do not use these indicators for their study on the link between party systems characteristics and democracy, but employ only party age and legislative volatility.

Further shortcomings derive from the lack of data for African elections. Some of our cases are not included because they have held second elections only since 2000, which are not covered in the study. Furthermore, due to missing data Pedersen's volatility-index is calculated according to the seat share and not the vote share. Vote shares represent roots in society more adequately than seat shares that might be strongly distorted by the effects of electoral systems. ${ }^{3}$ Finally, though Kuenzi's and Lambright's model is the most sophisticated quantitative model for party system institutionalisation (at least for Africa), they do not measure the organisational strength

1. Generally, we tried to avoid double assignation of indicators. Because boycotts and losers' acceptance of results are acts by - at least - party officials and not veto players outside the party system both indicators suit polarisation far better. However, the possible suitability for both concepts of party system legitimacy and polarisation point once again to conceptual problems with institutionalisation, especially the subsumption of quite different characteristics.

2. This is probably the reason why they do not systematically correlate their scores with levels of democratisation.

3. This, however, does not seem to be a serious problem: Kuenzi and Lambright demonstrate that volatility scores are not systematically related to the district size as the most important technical variable influencing party systems (Lambright/Kuenzi 2001: 451). 
of political parties. While one could think of valid indicators such as the number of card-carrying members, funds, (paid) full-time party officials, number and maintenance of party offices throughout the country etc. it is obvious that these data require a special time-consuming study in the future. Furthermore, the role of potential veto actors is not captured by varying efforts to measure institutionalisation. ${ }^{1}$

We will try to measure party system institutionalisation with three indicators that correspond with the different dimensions of institutionalisation apart from the organisational aspect and the role of veto players.

For roots in society and regularity of inter-party competition we use - to some extent modified - volatility and party age. Roots in society is operationalised by the average party age per seat in 2004. For practical reasons we limit our observation to parties with a minimum representation in parliament of 5 per cent of the seats. In order to give small parties no undue weight in the values, we have calculated average party age according to their actual seat share (party age per seat). As weak roots in society we define a party age of less than 15 years (e.g. after 1990). Party age per seat over 15 and 30 years is coded as medium and high party system institutionalisation respectively.

Regularity of inter-party competition is measured by Pedersen's volatility index. Similarly to Kuenzi and Lambright we had to use seat shares because detailed information on vote shares was not available, especially in plurality systems and two-round-plurality systems. For the sake of uniformity - most of the cases have had only two elections - we limit our observations to the volatility between the two last elections. ${ }^{2}$ Volatility below 20 , up to 40 and over 40 will indicate high, medium and low institutionalisation respectively.

We operationalise the (popular) legitimacy of the party system by using the turnout as a percentage of registered voters in legislative elections on average. Though low participation rates can be the result of poor administration, we assume that these problems tend to concern mainly the registration process. That is why we use the turnout of registered voters. Though still a proxy variable, it seems to be very plausible that low turnout rates point to low legitimacy of the party system with the population, especially

1. We refrained from testing it by using the number of interventions into politics by the military, because military interventions often mean a breakdown of democracy per se; moreover, the military is not the only veto player.

2. In addition, average volatilities of all elections were calculated but proved to have worse correlations. 
when participation decreases substantially. It seems more favourable than the model of Kuenzi and Lambright (2001) because no direct action of parties is involved. We define as low turnouts rates below 50 per cent, as high all those over two thirds of the registered voters, and medium all values in between.

Whether democratic multi-party systems show relatively high levels of institutionalisation is tested by all three indicators for institutionalisation individually and then combined in an additive Total Institutionalisation Score (TIS). All individual values of indicators are converted into an assessment whether they are low, medium or high (coding 1-3). Then, TIS sums up the individual values per country and divides them by three. A TIS value below 2 is looked upon as generally low institutionalisation. A minimum of 1 would mean participation below 50 per cent, volatility over 40, and party age lower than 15 years. A maximum of 3 would mean a turnout above 66.7 per cent, volatility below 20 and party age over 30 years (for further details, see Appendix II).

Institutionalisation scores produce somewhat more impressive results than fragmentation scores. As for the individual indicators, volatility gives the weakest support for our hypothesis. 12 cases do not match the assumption that democratic cases show low levels of volatility. Nine deviant cases for participation rates are not impressive either. The seven exceptions from the hypothesis for party age per seat are second best to our additive TIS, which reduces the number of deviant party systems to four (see Table 6). Regrettably, three of them, Benin, Mali and - to a lesser extent - Sao Tomé are democratic multi-party systems. Cameroon with its strong authoritarian tendencies turns out to be relatively highly institutionalised.

Extremely weak institutionalisation can be discovered primarily in Francophone cases. The multi-party systems with minimum TIS are Mali, Burkina Faso, the Comoros, and Niger. Botswana and Cape Verde get maximum ratings. This is also true for South Africa, Namibia and Mauritius. The case of the latter deserves more detailed explanation because sometimes the party system institutionalisation is characterised as low (Carroll and Carroll 1999: 180f, 193f). Although a number of spin-offs occurred in the 1980s, since the early 1990s (with the MMM, MSM and the PT/MLP), we have generally had almost the same parties that are active, albeit in different coalitions. What makes the party system appear to be volatile are the coalitions, in which the parties contest elections and the 
Table 6: Institutionalisation of party systems and democratic performance

\begin{tabular}{|c|c|c|c|}
\hline TIS & Free & Partly free & Not free \\
\hline High (TIS: 2,7-3) & $\begin{array}{l}\text { Botswana } \\
\text { Cape Verde } \\
\text { Mauritius } \\
\text { Namibia } \\
\text { South Africa }\end{array}$ & & Cameroon \\
\hline $\begin{array}{l}\text { Medium } \\
\text { (TIS: } 2-2,3 \text { ) }\end{array}$ & Sao Tomé & $\begin{array}{l}\text { Gabon } \\
\text { Sierra Leone } \\
\text { Ethiopia }\end{array}$ & $\begin{array}{l}\text { CAR } \\
\text { Equatorial-Guinea } \\
\text { Guinea } \\
\text { Togo }\end{array}$ \\
\hline Low (TIS: 1-1,7) & $\begin{array}{l}\text { Benin } \\
\text { Mali }\end{array}$ & $\begin{array}{l}\text { Burkina Faso } \\
\text { Comoros } \\
\text { Congo } \\
\text { Djibouti } \\
\text { Gambia } \\
\text { Niger } \\
\text { Nigeria } \\
\text { Zambia }\end{array}$ & $\begin{array}{l}\text { Chad } \\
\text { Côte d'Ivoire } \\
\text { Mauritania } \\
\text { Zimbabwe }\end{array}$ \\
\hline Deviant cases & 3 & 0 & 1 \\
\hline
\end{tabular}

plurality electoral system in three-member districts that usually results in marginalising losing coalitions (Kuenzi and Lambright 2001: 450). ${ }^{1}$

All in all, the correlation is not as impressive as theory predicts. ${ }^{2}$ This is not only because of the deviations and the ambiguity of some of the operationalisations that were discussed earlier. Again, 'not free' and 'partly free' cases do not differ in the theoretically expected way. 'Partly free' cases even appear to have worse scores on average than 'not free' systems (see Appendix II).

Nevertheless, before testing on a more profound base of information has taken place, we can conclude that there is a certain tendency that highly institutionalised party systems have somewhat better chances to sustain democracy than others (see also Kuenzi and Lambright 2005: 440).

\subsection{Polarisation}

It is surprising how rarely the dimension of party system polarisation has been tested, although it was already included in Sartori's classic study of

1. The compensatory 'best-loser"-system that enables the representation of hitherto unsuccessful candidates if they belong to a communal group so far underrepresented is applied regardless of the candidate's party affiliation.

2. For a different view on the effects of institutionalisation (volatility) - depending on surrounding conditions - see Kuezi and Lambright (2005: 440). 
1976. It is not even mentioned in the most advanced studies on the subject (Karvonen and Anckar 2002; Kuenzi and Lambright 2005). The respective hypothesis on the connection between polarisation and multi-party democracy has already been outlined and is as plausible as simple: democratic multi-party systems show lower levels of confrontation than non-democratic party systems.

As noted above, the notion of party system polarisation cuts into two aspects. As for ideological distance or programmatic differences, several scholars have pointed to the low ideological salience in African party systems (Van de Walle 2003: 304f; Erdmann 1999; 2002; 2004). Apparently, party manifestos and programmes do not play a significant role in contemporary African party systems. Ideological extremism, whether right or left wing, especially after the collapse of communism in Eastern Europe, is widely absent on the continent. ${ }^{1}$ Furthermore, Van de Walle explains the low ideological salience by strong personalism and the lack of labour or church-based political parties. On the system level it seems to be plausible that - different from Western countries - social cleavages underlying the party systems are primarily based on ethnic, regional or religious identity (Erdmann and Weiland 2001). In this context, it does not seem a particularly serious shortcoming that comprehensive data for ideological differences - gained through party manifesto analysis or opinion polls with members, officials and the population - are not available. Thus, a meaningful test on ideological differences is impossible at this point of time. ${ }^{2}$

The empirical study of the behavioural dimension - confrontation or co-operation between parties - faces problems as well but is by no means impossible. Since there are no established indices and little readily available data for the degree of confrontation between parties we have to think about an appropriate operationalisation for inter-party polarisation. Unfortunately, probably valid indicators such as attitudes towards opponent parties by party leaders, party members, and supporters, the prevalence of problematic behavioural patterns such as verbal intransigence, threats, and law suits against each other, co-operation or conflict in coalitions and coalition potential require sophisticated quantitative and qualitative data, which still has to be collected for a comparative analysis.

1. It is even questionable whether the ideological affiliations of one-party states during the cold war were as strong as frequently perceived from outside Africa.

2. Nevertheless, careful empirical testing of the hypothesis is by no means superfluous. 
For the aforementioned practical reasons we will operationalise polarisation by the prevalence of election boycott by opposition parties, ${ }^{1}$ of electoral violence and of whether losers do accept - immediately, hesitantly or not at all - the results of elections. ${ }^{2}$ The data base is the compilation of Lindberg (2004: 93-100). Regardless of the reasons, a high prevalence of boycott, violence and disputed results shows clearly that inter-party relations are marked by confrontation (see also Mehler in this volume). ${ }^{3}$

We put the indicators to test both individually and combined in an additive Total Polarisation Score (TPS). All values are calculated per election (coding from 0-6). TPS sums up the individual values per country and per election. A score of 0 means no problematic incident at all, a score of 6 means serious incidents in all areas (full opposition boycott, widespread violence, complete refusal of results). For further details, see Appendix III.

In contrast to measures for fragmentation and - to a lesser degree - institutionalisation, all indicators have strong and impressing explanatory power. The weakest indicator is the prevalence of electoral boycott, the strongest is whether losers accept the results. Maybe surprisingly, electoral violence comes in only third, after the combined measurement of all features (TPS). A more qualitative perspective illustrates the close connection between low polarisation and success of democracy (see Table 7). If we distinguish between low, medium and high polarisation and expect democratic party systems to display low levels, only Mali is returned as a deviant case for her relatively high levels of confrontation. ${ }^{4}$ All non-democratic multi-party systems are in full line with the theoretical expectations. As shown in Table 7, not a single non-democratic case has a medium polarisation level. The level of polarisation significantly distinguishes party systems in our sample.

1. In theory only, an election boycott by incumbent ruling parties is possible.

2. We tested both presidential and parliamentary elections because inter-party relations concern presidential elections, too.

3. Boycotting elections and refusing their results strongly indicate problems at the leadership level. Electoral violence during or after campaigns may be stimulated by party officials or not, commonly party militants or party supporters are involved in it. In any case, it reflects confrontation at a lower level of party organisation.

4. It should be noted here, that they can be traced back to the very problematic 1997 elections that were marred by irregularities such as boycott, violence and refusal to accept the results. 
Table 7: Polarisation, democracy and multi-party systems

\begin{tabular}{|c|c|c|c|}
\hline \multirow[b]{2}{*}{ Polarisation score } & \multirow{2}{*}{$\begin{array}{l}\text { Democratic } \\
\text { Free }\end{array}$} & \multicolumn{2}{|c|}{ Non-democratic } \\
\hline & & Partly free & Not free \\
\hline Low $(0-1)$ & $\begin{array}{l}\text { Benin } \\
\text { Botswana } \\
\text { Cape Verde } \\
\text { Mauritius } \\
\text { Namibia } \\
\text { Sao Tomé } \\
\text { South Africa }\end{array}$ & & \\
\hline \multicolumn{4}{|l|}{ Medium $(1-2)$} \\
\hline High $(2-3)$ & & $\begin{array}{l}\text { Burkina Faso } \\
\text { Congo } \\
\text { Djibouti } \\
\text { Ethiopia } \\
\text { Gabon } \\
\text { Gambia } \\
\text { Niger } \\
\text { Zambia }\end{array}$ & $\begin{array}{l}\text { CAR } \\
\text { Chad } \\
\text { Guinea } \\
\text { Mauritania } \\
\text { Togo } \\
\text { Zimbabwe }\end{array}$ \\
\hline Very high $(>3)$ & Mali & $\begin{array}{l}\text { Comoros } \\
\text { Nigeria } \\
\text { Sierra Leone }\end{array}$ & $\begin{array}{l}\text { Cameroon } \\
\text { Côte d'ivoire } \\
\text { Equatorial Guinea }\end{array}$ \\
\hline Deviant cases & 1 & 0 & 0 \\
\hline
\end{tabular}

As for (other) individual cases we should point to the best case scenarios. Botswana is the top scorer with a TPS of only 0.43 problematic incidents. Electoral violence is completely absent, low scores for electoral boycott and protesting results derive from elections in 1969 and 1974. Botswana's index value matches with qualitative assessments of the party system, which is characterised by a culture of 'sit down and talk' (Basedau 2003: 214ff). Confrontation is rather to be found within the parties than between them (Molomo in Salih 2003: 297ff). Cape Verde is close to minimum confrontation as well. In the presidential elections in 1996 the presidential opposition candidate rather withdrew due to the lack of meaningful chances for winning. Electoral violence is limited to isolated incidents in 1991 and 1995. Remarkably, the transfer of power in 2000/2001 was not accompanied by any problematic incident.

The worst case is without doubt the Comoros. The value of 4.9 incidents per election is close to the maximum of 6 . In fact, all elections from 1992 to 1996 were marred with widespread violence, boycott, and wild protests by defeated candidates and parties. High polarisation scores of 4 in Cameroon and Equatorial-Guinea mirror the unsuccessful struggle of marginalised opposition against entrenched one-party hegemony. In Côte 
d'Ivoire, markedly highly violent polarisation (top violence score) heralded the outbreak of the civil war in late 2002 .

However, the close connection might not be as impressive as it seems at first glance. First, the Lindberg compilation does not cover a number of recent elections since 2002. We refrained from completing the values in order to maintain a consistent data base. The election observation reports - the basis of Lindberg's compilation - were not available for the recent elections as of the completion of this study.

Second, we hardly discover - similar to both fragmentation and institutionalisation - any difference between 'partly free' and 'not free' cases. For a perfect correlation one should expect the 'partly free' cases to be superior to 'not free' multi-party systems. Both subgroups show almost identical mean values in all measures (see Appendix III).

Third, one could question the validity of the indicators because all of them are very close to elections. Proximity to elections is not a problem because party politics commonly becomes heated when access to power is at stake. In fact, it seems to be especially suitable to analyse elections because of this. A possible objection derives from another ambiguity: Are boycott of elections, electoral violence and 'bad losers' in fact reflections of real or anticipated electoral fraud and thus measures for competitive elections? Because competitive elections, in turn, are a necessary condition for democracy, any link between democracy and polarisation would be trivial or even an artefact. However, our measures for polarisation are not in the first place indicators for competitive elections: opposition boycott, electoral violence, and protesting election outcomes do not necessarily mean that elections were not free and fair (Lindberg 2004; Appendix IV). In CAR, Djibouti and Niger, for instance, irregularities were overwhelmingly not significant for the outcome whereas polarisation reaches consistently high levels. ${ }^{1}$ We can conclude, therefore, that the indicators employed are not in the first place proxies for competitiveness of elections. However, it might be favourable to additionally measure polarisation by indicators more independent of elections. As outlined earlier, measures such as attitudes of party supporters and officials, inter-party violence and verbal intransigence between electoral campaigns etc. require advanced and in-depth research.

Finally, and most disquieting, we still face the problem of attribution and causation, which most probably applies to other features of the party

1. Consequently, we did not use the potential indicator of free and fair elections on our sample (used by Kuenzi \& Lambright for institutionalisation). As a necessary condition of democracy this would have produced artificial causal connections. 
system as well. It still remains unclear whether our indicators are genuine attributes of the party systems or, alternatively, quite powerful individuals or ordinary citizens. Van de Walle, amongst others, has pointed to strong personalism in African party systems (2003: 305). This corresponds to qualitative findings in 13 African countries by the author (Basedau 2003: 231). On an abstract level, it is possible that high party system polarisation is not the cause but the expression of a polarised authoritarian political culture.

Nevertheless, the fact remains that our analysis for polarisation has returned strong correlations. In the qualitative perspective, the only exception is Mali. Before more sophisticated work has been done, there is strong empirical support for our hypothesis that confrontation in inter-party relations is not conducive to democracy.

\subsection{A combined perspective}

Notwithstanding certain reservations with regard to data, operationalisations and theoretical considerations and interpretations we can summarise our present empirical findings as follows: fragmentation has weak, institutionalisation has some and polarisation has strong explanatory value for democracy. Our starting point, however, was a combined functionalist assumption: democratic multi-party systems are characterized by moderate fragmentation, low polarisation, and high institutionalisation.

We will test whether a combined perspective produces more satisfying results. For this purpose we use a 'best system' as an ideal type. As predicted by our functionalist approach, we should at least find less problematic aspects with our democratic multi-party systems. In turn, non-democratic cases are expected to display several shortcomings.

As shown in Table 8 (and Appendix IV) all non democratic multi-party systems have worst or near worst systems that is, they have at least two deviations from the ideal type. Though this might be impressive we have to concede that only two democratic cases, the islands of Mauritius and Cape Verde, have a 'best system". Four cases show only one deviation in terms of one-party dominance or institutionalisation (Sao Tomé) and are still at least partly in accord with the functionalist approach. However, two cases cannot be explained by our model: the democratic multi-party systems in Mali and Benin each display two deviations. Both share 'inchoate' institutionalisation, Benin scores poor on fragmentation, Mali on polarisation. 
With two exceptions only, all in all, our model provides for a probabilistic explanation. Yet, we should not fall into the 'trap of probabilism' and settle for our threefold functionalist model: any deviant case clearly indicates that - except for problems due to operationalisation and data - other factors must be involved. ${ }^{1}$

Table 8: 'Best' and 'worst' party systems and democratic performance

\begin{tabular}{|c|c|c|c|}
\hline & \multirow{2}{*}{$\begin{array}{l}\text { Democratic } \\
\text { Free }\end{array}$} & \multicolumn{2}{|c|}{ Non-democratic } \\
\hline & & Partly free & Not free \\
\hline Best system & $\begin{array}{l}\text { Cape Verde } \\
\text { Mauritius }\end{array}$ & & \\
\hline Near best system & $\begin{array}{l}\text { Botswana } \\
\text { Sao Tomé } \\
\text { Namibia } \\
\text { South Africa }\end{array}$ & & \\
\hline Near worst system & $\begin{array}{l}\text { Benin } \\
\text { Mali }\end{array}$ & $\begin{array}{l}\text { Comoros } \\
\text { Niger } \\
\text { Nigeria } \\
\text { Sierra Leone }\end{array}$ & $\begin{array}{l}\text { Cameroon } \\
\text { CAR } \\
\text { Côte d' Ivoire }\end{array}$ \\
\hline Worst system & & $\begin{array}{l}\text { Burkina Faso } \\
\text { Congo } \\
\text { Djibouti } \\
\text { Ethiopia } \\
\text { Gabon } \\
\text { Gambia } \\
\text { Zambia }\end{array}$ & $\begin{array}{l}\text { Chad } \\
\text { Equatorial-Guinea } \\
\text { Guinea } \\
\text { Mauritania } \\
\text { Togo } \\
\text { Zimbabwe }\end{array}$ \\
\hline Deviant cases & 2 & 0 & 0 \\
\hline
\end{tabular}

"Best system": moderate fragmentation, low polarisation, high institutionalisation; 'worst system": low or high fragmentation, high polarisation, low or medium institutionalisation.

Moreover, we have to keep in mind that the combined functionalist approach provides for a worse explanation than polarisation alone. Furthermore, albeit less worrying, the fact that for both the combined and individual measures of party system characteristics no substantial differences between 'partly free' and 'not free' were found is contrary to what should be expected of a perfect causal connection.

1. Of course, if we want to adhere to the functional approach as developed initially, we could expect that due to the dysfunctional features in their party systems especially Mali and to some extent Benin will collapse or lapse into semi-authoritarianism in the near future. Alternatively, and more consistent with our empirical findings, we have rather to conclude that the relationship between party system characteristics and democratisation is different than expected. 


\section{Conclusions}

Empirically, there is a strong tendency that party system characteristics are systematically linked to the varying success of democracy in sub-Saharan Africa. This roughly matches with the findings of a recently published study (Kuenzi and Lambright 2005). Nevertheless, our findings differ from our initial theoretical assumption: it is not the combined functionalist model but - in other studies widely untested - polarisation alone that distinguishes democratic and non-democratic party systems most significantly. Despite the only exceptions of Mali and - to a lesser extent - Benin our results are not as impressive as they may seem at first sight.

The first caveat refers to the poor data situation. Due to lack of detailed information we were unable to measure some of the more valid indicators such as the volatility of vote shares in recent elections. In addition, some of the cases and some of the most recent elections in some countries remained untested in certain respects, most prominently polarisation. It is beyond doubt that this gap should be filled in the near future.

Moreover, our study has revealed the need for new indicators and additional data that could not possibly be made available for this study. This applies first of all to new measures for polarisation that should cover the period between elections such as attitudes towards rival parties, behavioural patterns in parliament and coalitions etc. Especially, we could not operationalise to full satisfaction the more sophisticated concept of institutionalisation - that itself still deserves conceptual rethinking - in particular features such as the influence of veto-players and traits of political parties rather than party systems such as organisational strength of political parties and intra-party politics. Just like innovative indicators for polarisation it is by no means impossible even to quantify organisational strength of parties. Possible measures are for instance the number of members, fulltime officials, budgets and party office networks. The efforts in question, however, will require costly and time consuming research.

The major theoretical caveat refers to the problem of attribution and causation. Correlation must not be equated with causation. This divides into two aspects. With regard to direction and sequence of causation we face a 'chicken and egg problem": Are problematic features of party systems effects or expressions of an authoritarian or violent political system or 
political culture rather than their proper causes? Maybe a research design that systematically compares party system characteristics before outright breakdowns could resolve the problem. ${ }^{1}$ However, simple linear relations do not seem plausible; a complex and dynamic interplay of the party system and the political system is more probable. Thus, research designs capturing dynamics, interplays and complexity would be helpful in the future.

Related to this, we must consider the impact of context conditions: since the very same phenomenon can have multiple causes, even strong correlations (and the required chronological sequence given) can be misleading when in fact both dependent and independent variables depend on a third variable. We tried to tackle this problem by applying an approximate method of difference by comparing democratic and non democratic multiparty systems in sub-Saharan Africa. Yet, we have to keep in mind that the region does not constitute the required ceteris paribus in contextual variables. Hence, it can by no means be ruled out that numerous variables such as the role of the military, behavioural patterns of elites, socio-economic dynamics, inter-communal relations or institutional variables (Basedau 2003; Dahl 1998; Schmidt 2000) are superior in explaining the success or failure of democracy.

Controlling all these variables was clearly beyond the scope of this article. However, future research designs should test their explanatory value in comparison to party system characteristics. In fact, the study of Kuenzi and Lambright (2005: 433) reveals that socio-economic variables independently account for around 40 per cent (and institutional variables for around 21 per cent) whilst party system characteristics alone explain a mere 15 per cent of the variance.

More importantly, taking into account the intermediate position of the party system, the interplay between party system characteristics and contextual variables should be subject to in-depth investigation. Several scholars have already outlined first findings and hypotheses with regard to clientelism, presidentialism, ethnicity or electoral systems (Van de Walle 2003; Karvonen and Anckar 2002; Kuenzi and Lambright 2005: 436).

Testing the over-all explanatory value of competing variables can be conducted through quantitative or macro-qualitative studies, but for detecting rather complex causal relationships, however, we need contextually highly homogenous countries that are closer to a method of difference in

1. A provisional comparison of breakdown cases reveals that authoritarian regression occurs in any degree of fragmentation and institutionalisation. Once again, it is polarisation that has highly superior explanatory value. 
Mill's or Sartori's sense than quantitative or macro-qualitative designs. For this purpose qualitative 'small N' designs will be preferable that have the further advantage of enabling a 'large N' in independent variables. Deviation from theoretical assumptions as found in 'inchoate' party systems in Benin and Mali could be another promising criterion of selection for 'small $\mathrm{N}$ ' and in-depth-comparisons addressing pertinent questions such as why party systems in Mali und Benin, though apparently dysfunctional, have been working to some extent or at least have not dramatically damaged democracy. ${ }^{1}$ Under which circumstances are 'inchoate' party systems compatible with democracy? Does the socio-economic and political context apart from parties make the difference?

It would be premature to try to answer all these questions at this point. Though our findings suggest a strong relationship, we have accomplished nothing but a first step on a long road ahead. Before having carefully addressed the problems outlined above we should at least be cautious about any claim on the link between party systems and democracy in sub-Saharan Africa.

\section{References}

Ake, C. (1996), Democracy and Development in Africa. Washington: Brookings Institution Press.

Basedau, M. (2002), 'Zum Zusammenhang von Wahlsystem, Parteiensystem und Demokratiestabilität in Afrika. Kritische Anmerkungen zum Potenzial von Electoral Engineering', Africa Spectrum 37: 3, pp. 311-333.

Basedau, M. (2003), Erfolgsbedingungen von Demokratie im subsaharischen Afrika. Ein systematischer Vergleich ausgewählter Länder. Opladen: Leske und Budrich.

Bendel, P. (1996), Parteiensysteme in Zentralamerika. Erklärungsfaktoren und Typologien. Opladen: Leske und Budrich.

Bendel, P. and F. Grotz (2001), 'Parteiensysteme und Demokratisierung. Junge Demokratien in Afrika, Asien und Lateinamerika im Vergleich', Nord-SüdAktuell, 15: 1, pp. 70-80.

Beyme, K. von (1997), 'Parteien im Prozeß der demokratischen Konsolidierung', in Merkel, W. and E. Sandschneider (eds) Systemwechsel 3. Opladen: Leske und Budrich, pp. 23-56.

Bogaards, M. (2000) 'Crafting Competitive Party Systems: Electoral Laws and the Opposition in Africa', Democratization 7: 4, pp. 164-166.

Bogaards, M. (2004), 'Counting Parties and Identifying (Dominant) Party Systems in Africa', European Journal of Political Research 43, pp. 173-197.

1. It might be an eurocentristic view to expect that parties must be the same in Africa in order to be compatible with democracy. 
Bratton, M. and N. Van de Walle (1997), Democratic Experiments in Africa. Regime Transitions in Comparative Perspective. Cambridge: Cambridge University Press.

Carroll, B. and T. Carroll (1999), 'The Consolidation of Democracy in Mauritius', Democratization 6: 1, pp. 179-197.

Dahl, R.A. (1971), Polyarchy: Participation and Opposition. New Haven: Yale University Press.

Dahl, R.A. (1998) On Democracy. New Haven and London: Yale University Press.

Emminghaus, C. (2002), 'Politische Parteien und ihre Funktion in afrikanischen Demokratien. Analysekonzept und empirische Befunde zu Botswana und Namibia', Afrika Spectrum 37: 3, pp. 287-310.

Erdmann, G. (1999), 'Parteienforschung zu Afrika - Versuch eines Neuanfangs', Afrika Spectrum 34: 3, pp. 375-393.

Erdmann, G. (2002), 'Zur Typologie politischer Parteien in Afrika', Afrika Spectrum 37: 3, pp. 259-285.

Erdmann, G. (2004), 'Party Research: Western Bias and the 'African Labyrinth', Democratization $11: 3$, pp. $63-87$.

Erdmann, G. and H. Weiland, (2001), 'Gesellschaftliche Konfliktlinien, Ethnizität und Parteienformation in Afrika', in Eith, U. and G. Mielke (eds) Gesellschaftliche Konflikte und Parteiensysteme. Länder- und Regionalstudien. Wiesbaden: Westdeutscher Verlag, pp. 246-262.

Fomunyoh, C. (2001), 'Francophone Africa in Flux. Democratization in Fits and Starts', Journal of Democracy 12: 3, pp. 37-50.

Gunther, R. and L. Diamond (2003), 'Species of Political Parties. A New Typology', Party Politics, 9: 2, pp. 167-199.

Karvonen, L. and C. Anckar (2002), 'Party Systems and Democratization: A Comparative Study of the Third World', Democratization, 9: 3, pp. 11-29.

Kuenzi, M. and G. Lambright (2001), 'Party System Institutionalisation in 30 African Countries', Party Politics 7: 4, pp. 437-468.

Kuenzi, M. and G. Lambright (2005), 'Party Systems and Democratic Consolidation in Africa's Electoral Regimes', Party Politics 11: 4, pp. 425-446.

Laakso, M. and R. Taagepera (1979), "Effective" Number of Parties. A Measure with Application to West Europe', Comparative Political Studies 12: 1, pp. 3-27.

Lijphart, A. (1975), 'The Comparable Cases Strategy in Comparative Research', Comparative Political Studies 8, pp. 158-175.

Lindberg, S.I. (2004) 'The Democratic Qualities of Competitive Elections: Participation, Competition and Legitimacy in Africa', Commonwealth and Comparative Politic 41: 1, pp. 61-105.

Lipset, S.M. (2000), 'The Indispensability of Political Parties', Journal of Democracy 11: 1 , pp. 48-55.

Lipset, S.M. and S. Rokkan (eds) (1967), Party Systems and Voter Alignments. CrossNational Perspectives. New York: Free Press.

Mainwaring, S.P. (1999), Rethinking Party Systems in the Third Wave of Democratization. The Case of Brazil. Stanford: Stanford University Press.

Mainwaring, S.P. and T.S. Scully (eds) (1995), 'Introduction. Party Systems in Latin America', in Mainwaring, S.P. and T.S. Scully (eds) Building Democratic Institutions. Party Systems in Latin America. Stanford: Stanford University Press, pp.1-34. 
Merkel, W. (1999), 'Defekte Demokratien' in Merkel, W. and A. Busch (eds)

Demokratie in Ost und West, Festschrift für K. von Beyme. Frankfurt: Suhrkamp, pp. 361-381.

Mill, J.S. (1997), Zur Logik Moralwissenschaften. Frankfurt a. M.: Klostermann.

Monga, C. (1997), 'Eight Problems with African Politics', Journal of Democracy 8: 3, pp. $156-170$.

Mozaffar, S. et al. (2003), 'Electoral Institutions, Ethnopolitical Cleavages, and Party Systems in Africa's Emerging Democracies', American Political Science Review 97: 3, pp. 379-390.

Nohlen, D. (2002), 'Vergleichende Methode', in Nohlen, D. and R.O. Schultze (eds) Lexikon der Politikwissenschaft, Theorien-Methoden-Begriffe, München: Beck, pp. 1020-1031.

Nohlen, D. (2003), Wahlrecht und Parteiensystem, 4. Auflage. Opladen: Leske und Budrich.

Nohlen, D. et al. (eds) (1999), Elections in Africa. A Data Handbook. Oxford: Oxford University Press.

Pedersen, M.N. (1983), 'Changing Patterns of Electoral Volatility in European Party Systems', in Daalder, H. and P. Mair (eds) Western European Party Systems. Continuity and Change. Beverly Hills: Sage Publications, pp. 29-66.

Randall, V. and L. Svåsand, (2002a), 'Party Institutionalization in New Democracies', Party Politics 8: 1, pp. 5-29.

Randall, V. and L. Svåsand, (2002b), 'Political Parties and Democratic Consolidation in Africa', Democratization 9: 3, pp. 30-52.

Randall, V. and L. Svåsand, (2002c), 'Introduction: The Contribution of Parties to 'Democracy and Democratic Consolidation', Democratization 9: 3, 1-10.

Salih, M.M.A. (2003), African Political Parties. Evolution, Institutionalisation and Governance. London and Sterling: Pluto Press.

Sandbrook, R. (1996), 'Transitions without Consolidation. Democratization in Six African Cases', Third World Quarterly 17: 1, pp. 69-87.

Sartori, G. (1976), Parties and Party Systems. A Framework for Analysis. Cambridge: Cambridge University Press.

Sartori, G. (1994a), Comparative Constitutional Engineering. An Inquiry into Structures, Incentives and Outcomes. Basingstoke and Houndmills: Macmillan.

Sartori, G. (1994b), 'Compare Why and How. Comparing, Miscomparing and the Comparative Method', in Dogan, M. and A. Kazancigil (eds) Comparing Nations: Concepts, Strategies, Substance. Oxford: Blackwell, pp. 14-34.

Schmidt, M.G. (2000), Demokratietheorien. Eine Einführung. Opladen: Leske und Budrich.

Taagepera, R. and B. Grofman (2003), 'Mapping the Indices of Seats-Votes Disproportionality and Inter-Election Volatility', Party Politics 9: 6, pp. 659-677.

Van de Walle, N. (2003), 'Presidentialism and Clientelism in Africa's Emerging Party Systems', Journal of Modern African Studies 41: 2, pp. 297-321.

Van de Walle, N. and K.S. Buttler, (1999), 'Political Parties and Party Systems in Africa's Illiberal Democracies', Cambridge Review of International Affairs 8: 1, pp. 14-28.

Wiesendahl, E. (1980), Parteien und Demokratie. Eine soziologische Analyse paradigmatischer Ansätze der Parteienforschung. Opladen: Leske und Budrich. 


\section{Appendix I: Fragmentation}

\begin{tabular}{|l|l|l|l|l|l|l|l|l|}
\hline & Time span & $\begin{array}{l}\text { Dominance } \\
\text { (absolute } \\
\text { majorities } \\
\text { last two } \\
\text { elections })\end{array}$ & $\begin{array}{l}\text { Electoral } \\
\text { transfers } \\
\text { of power } \\
(* \text { founding } \\
\text { elections } \\
\text { only) }\end{array}$ & $\begin{array}{l}\emptyset \mathrm{N} \\
\text { effective } \\
\text { legislative } \\
\text { parties }\end{array}$ & $\begin{array}{l}\text { Ø N of } \\
\text { legislative } \\
\text { parties }\end{array}$ & $\begin{array}{l}\emptyset \text { Seat } \\
\text { share } \\
\text { winner }\end{array}$ & $\begin{array}{l}\text { } \\
\text { share } \\
\text { runner } \\
\text { up }\end{array}$ & $\begin{array}{l}\text { Total } \\
\text { MFI }\end{array}$ \\
\hline
\end{tabular}

F R E E

\begin{tabular}{|l|l|l|l|l|l|l|l|l|}
\hline Benin & $1991-2003$ & No & Yes & 6.7 & 14.3 & 28.5 & 18.1 & 2.8 \\
\hline Botswana & $1966-1999$ & Yes & No* & 1.4 & 3.3 & 83.3 & 15 & 3.4 \\
\hline Cape Verde & $1991-200$ & No & Yes & 1.9 & 2.7 & 65.3 & 41.7 & 0.7 \\
\hline Mali & $1992-2002$ & No & Yes & 2.2 & 9 & 63.1 & 28.6 & 2.3 \\
\hline Mauritius & $1976-2000$ & No & Yes & 1.8 & 3.7 & 69.4 & 11.4 & 0.8 \\
\hline Namibia & $1989-1999$ & Yes & No* & 1.9 & 5.7 & 69.1 & 10 & 2.3 \\
\hline Sao Tomé & $1991-2002$ & No & Yes & 2.4 & 3 & 52.3 & 41.8 & 0.3 \\
\hline South Africa & $1994-1999$ & Yes & No* & 2.2 & 10.7 & 64.8 & 9.5 & 2.3 \\
\hline
\end{tabular}

N O T F R E E

\begin{tabular}{|l|l|l|l|l|l|l|l|l|}
\hline Cameroon & $1992-2002$ & Yes & No & 2.1 & 5.3 & 64.1 & 12.2 & 1.7 \\
\hline CAR & $1993-1998$ & No & No* & 4.6 & 11 & 41.6 & 18.3 & 2 \\
\hline Chad & $1997-2002$ & Yes & No & 2.1 & 12.5 & 60.7 & 7.7 & 3 \\
\hline Côte d'Ivoire & $1991-2000$ & No & Yes & 1.7 & 4.3 & 73.6 & 41.8 & 2.6 \\
\hline Eq. Guinea & $1993-1999$ & Yes & No & 1.5 & 3.5 & 89.4 & 5 & 4 \\
\hline Guinea & $1995-2002$ & Yes & No & 1.8 & 7.5 & 68.4 & 17.4 & 2.5 \\
\hline Mauritania & $1992-2001$ & Yes & No & 1.4 & 4.3 & 84.1 & 4.9 & 4 \\
\hline Togo & $1994-2002$ & Yes & No & 1.7 & 4.3 & 76.5 & 3.7 & 2.6 \\
\hline Zimbabwe & $1980-2000$ & Yes & No* & 1.8 & 3.2 & 73.7 & 47.5 & 2.4 \\
\hline
\end{tabular}

PAR T L F R E E

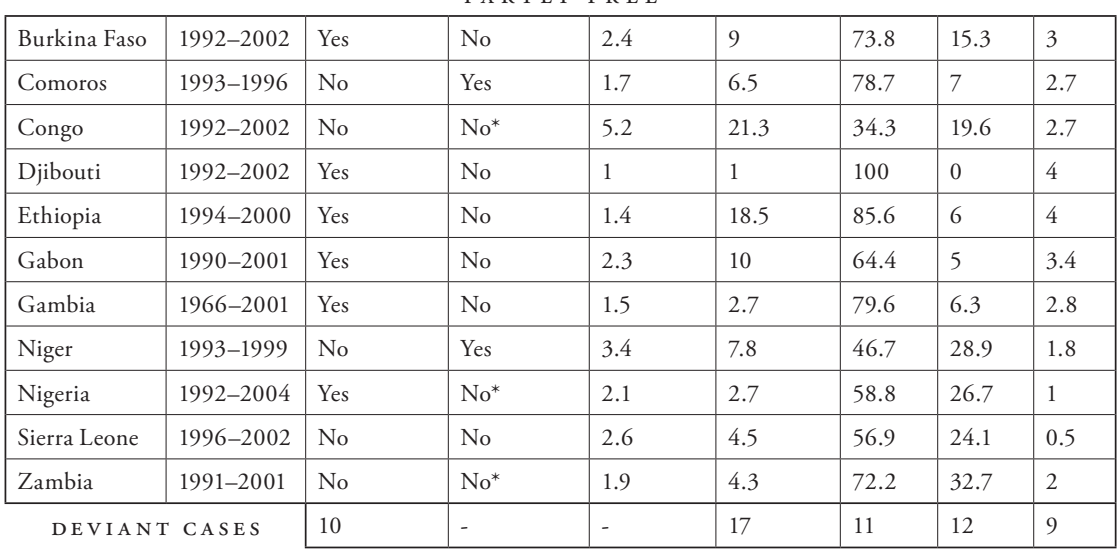




\section{Appendix II: Institutionalisation}

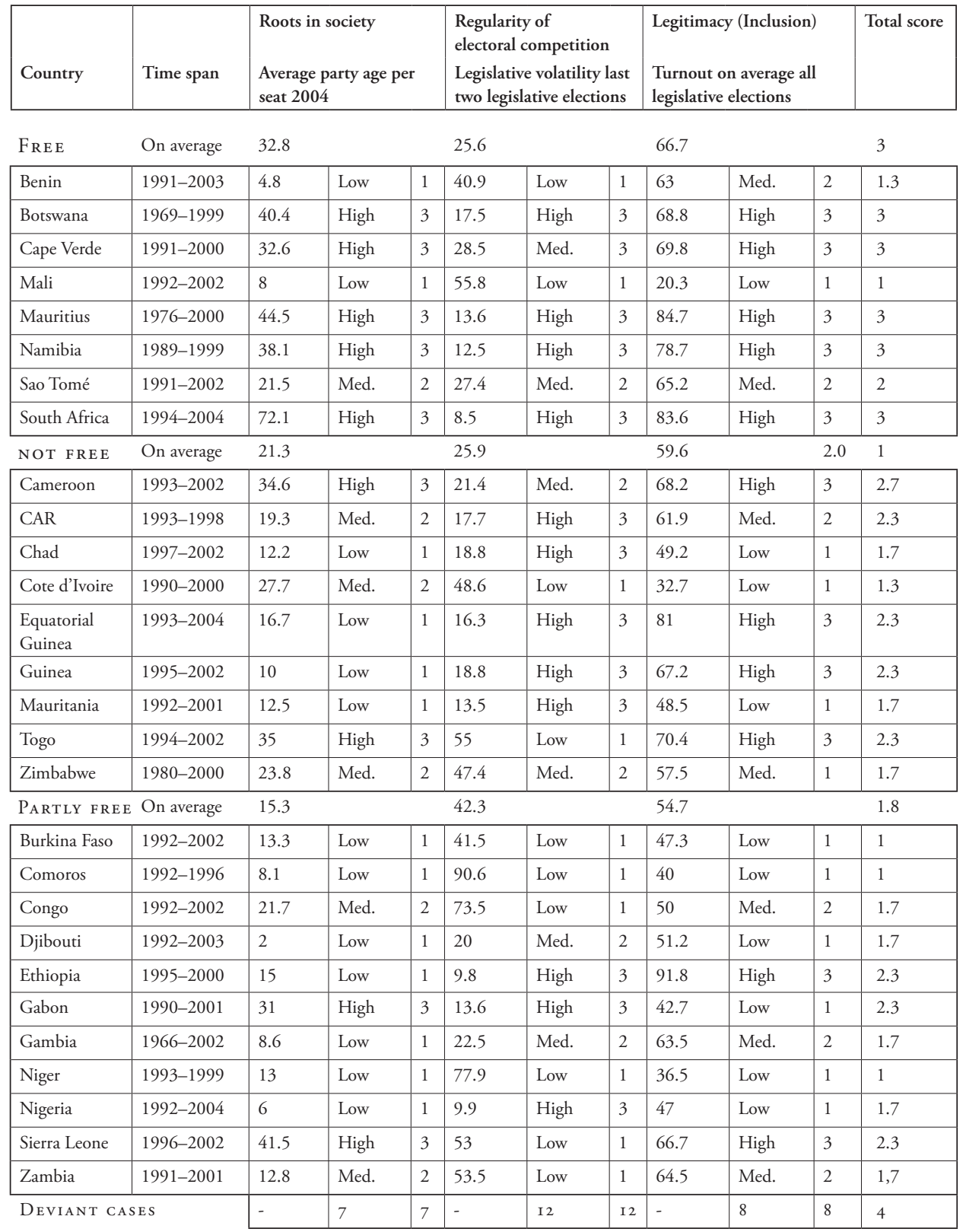




\section{Appendix III: Polarisation}

\begin{tabular}{|c|c|c|c|c|c|c|c|}
\hline Country & $\begin{array}{l}\text { No. of } \\
\text { presidential } \\
\text { and legi } \\
\text { slative } \\
\text { elections }\end{array}$ & Time span & $\begin{array}{l}\varnothing \\
\text { Oppositon } \\
\text { boycott- } \\
\text { score }\end{array}$ & $\begin{array}{l}\emptyset \\
\text { Electoral } \\
\text { violence- } \\
\text { score }\end{array}$ & $\begin{array}{l}\varnothing \text { Losers } \\
\text { accept- } \\
\text { ance }\end{array}$ & $\begin{array}{l}\text { Total } \\
\text { polari } \\
\text { sation } \\
\text { score }\end{array}$ & $\begin{array}{l}\text { Qualitative } \\
\text { assessment }\end{array}$ \\
\hline \multicolumn{2}{|l|}{ F R E E } & Average & 0.1 & 0.7 & 0.3 & 1.0 & \\
\hline Benin & 6 & $1991-2001$ & 0.00 & 0.00 & 0.67 & 0.67 & Low \\
\hline Botswana & 7 & 1969-1999 & $0.29^{*}$ & 0.00 & 0.14 & 0.43 & Low \\
\hline Cape Verde & 6 & 1991-2001 & 0.00 & 0.50 & 0.00 & 0.50 & Low \\
\hline Mali & 5 & 1992-1997 & 0.80 & 1.40 & 1.00 & 3.20 & High \\
\hline Mauritius & 7 & $1976-2000$ & 0.00 & 0.29 & 0.29 & 0.57 & Low \\
\hline Namibia & 5 & 1989-1999 & 0.00 & 0.80 & 0.20 & 1.00 & Medium \\
\hline Sao Tomé & 6 & $1991-2001$ & 0.00 & 0.50 & 0.17 & 0.67 & Low \\
\hline South Africa & 2 & 1994-1999 & 0.00 & 1.00 & 0.00 & 1.00 & Medium \\
\hline \multicolumn{2}{|l|}{ NOT FREE } & Average & 0.5 & 1 & 1.3 & 2.8 & \\
\hline Cameroon & 4 & 1992-1997 & 1.00 & 1.00 & 2.00 & 4.00 & Very high \\
\hline CAR & 5 & 1991-1998 & 0.20 & 1.40 & 0.80 & 2.40 & High \\
\hline Chad & 3 & $1996-2001$ & 0.00 & 1.00 & 1.00 & 2.00 & High \\
\hline Côte d'Ivoire & 6 & $1990-2000$ & 0.83 & 1.83 & 1.30 & 4.00 & Very high \\
\hline Eq. Guinea & 3 & 1993-1999 & 1.00 & 1.00 & 2.00 & 4.00 & Very high \\
\hline Guinea & 3 & 1993-1998 & 0.00 & 1.00 & 1.70 & 2.70 & High \\
\hline Mauritania & 5 & $1992-2001$ & 0.60 & 0.60 & 1.00 & 2.20 & High \\
\hline Togo & 4 & 1993-1999 & 0.50 & 0.67 & 1.75 & 3.75 & High \\
\hline Zimbabwe & 7 & $1980-2000$ & $0.43^{*}$ & 1.00 & 1.43 & 2.86 & High \\
\hline \multicolumn{2}{|l|}{ PARTLY FRE } & Average & 0.5 & 1 & 1.3 & 2.8 & \\
\hline Burkina Faso & 4 & $1991-1998$ & 0.50 & 1.00 & 1.25 & 2.75 & High \\
\hline Comoros & 7 & 1990-1997 & 1.14 & 1.71 & 2.00 & 4.90 & Very High \\
\hline Congo & 3 & $1992-1993$ & 0.00 & 0.67 & 1.30 & 2.00 & High \\
\hline Djibouti & 4 & 1992-1999 & 0.75 & 0.75 & 1.25 & 2.75 & High \\
\hline Ethiopia & 2 & 1995-2000s & 0.50 & 1.00 & 1.00 & 2.50 & High \\
\hline Gabon & 5 & $1991-2001$ & 1.00 & 1.20 & 1.60 & 3.00 & High \\
\hline Gambia & 10 & $1982-2002$ & 0.30 & 0.80 & 1.20 & 2.30 & High \\
\hline Niger & 7 & 1993-1999 & 0.29 & 0.86 & 1.14 & 2.29 & High \\
\hline Nigeria & 5 & 1992-1999 & 0.80 & 1.20 & 1.40 & 3.40 & High \\
\hline Sierra Leone & 2 & 1996 & 1.00 & 1.00 & 2.00 & 4.00 & High \\
\hline Zambia & 6 & $1991-2001$ & 0.17 & 1.17 & 1.30 & 2.67 & High \\
\hline
\end{tabular}




\section{Appendix IV: Combined values and assessments}

\begin{tabular}{|c|c|c|c|c|c|}
\hline Country & Fragmentation & Polarisation & $\begin{array}{l}\text { Institution } \\
\text { alisation }\end{array}$ & $\begin{array}{l}\text { Best-System } \\
\text { score }\end{array}$ & $\begin{array}{l}\text { In line with } \\
\text { theoretical } \\
\text { assumption }\end{array}$ \\
\hline \multicolumn{4}{|l|}{ F R E E } & \multicolumn{2}{|l|}{$\begin{array}{l}\text { Deviant } \\
\text { features }\end{array}$} \\
\hline Benin & High & Low & Low & 2 & No \\
\hline Botswana & Low & Low & High & 1 & Partly \\
\hline Cape Verde & Moderate & High & High & 0 & Yes \\
\hline Mali & Moderate & Low & Low & 2 & No \\
\hline Mauritius & Moderate & Low & High & 0 & Yes \\
\hline Namibia & Low & Low & High & 1 & Partly \\
\hline Sao Tomé & Moderate & Low & Medium & 1 & Partly \\
\hline South Africa & Low & Low & High & 1 & Partly \\
\hline \multicolumn{4}{|l|}{ NOT FREE } & \multicolumn{2}{|l|}{1} \\
\hline Cameroon & Low & High & High & 1 & Partly \\
\hline CAR & Moderate & High & Medium & 1 & Partly \\
\hline Chad & Low & High & Low & 0 & Yes \\
\hline Côte d'Ivoire & Moderate & High & Low & 1 & Partly \\
\hline Eq. Guinea & Low & High & Medium & 0 & Yes \\
\hline Guinea & Low & High & Medium & 0 & Yes \\
\hline Mauritania & Low & High & Low & 0 & Yes \\
\hline Togo & Low & High & Low & 0 & Yes \\
\hline Zimbabwe & Low & High & Low & 0 & Yes \\
\hline \multicolumn{6}{|l|}{ PARTLY FRE } \\
\hline Burkina Faso & Low & High & Low & 0 & Yes \\
\hline Comoros & Moderate & High & Low & 1 & Partly \\
\hline Congo & High & High & Low & 0 & Yes \\
\hline Djibouti & Low & High & Low & 0 & Yes \\
\hline Ethiopia & Low & High & Medium & 0.5 & Partly \\
\hline Gabon & Low & High & Medium & 0.5 & Yes \\
\hline Gambia & Low & High & Low & 0 & Yes \\
\hline Niger & Moderate & High & Low & 1 & Partly \\
\hline Nigeria & $\begin{array}{l}\text { Low to } \\
\text { moderate }\end{array}$ & High & Low & 0.5 & Partly \\
\hline Sierra Leone & Moderate & High & Medium & 1 & Partly \\
\hline Zambia & Low & High & Medium & 0.5 & Yes \\
\hline Deviant cases & 8 & 1 & 4 & -- & 2 \\
\hline
\end{tabular}




\section{Sources, notes and comments to the tables}

\section{Appendix I:}

Sources: Bogaards 2004 (draft); Nohlen et al. 1999, www.electionworld.org, Africa South of the Sahara.

Note: minor deviations due to rounding off are possible.

\section{Coding moderation of fragmentation:}

Number of relevant and effective parties per election:

No dominance (incl. absolute majority after transfer of power) and less than 4 effective legislative parties:

Absolute majority (less than two thirds, no transfer of power): $\quad 1$

Two thirds majority, no transfer of power: 2

Fragmentation over 4 effective legislative parties: $\quad 1$

Fragmentation over 5 effective legislative: $\quad 2$

Note: in founding elections a transfer of power is given credit

(no dominance $=0$ )

Marginalisation of opposition per election (regardless of turnover and dominance)

Runner up more than 25\% seat share:

Runner up less than $25 \%$ seat share:

Runner up less than $10 \%$ seat share:

0

1

2

Total moderation of fragmentation score

(values added, divided by $\mathrm{N}$ of elections):

Moderate: below average of added values per election

Immoderate: below average of added values per election

Appendix II:

Sources: own calculation on the basis of Lindberg (2004), Nohlen et al. (1999) and www.electionworld.org.

Coding Institutionalisation:

Roots in society:

Weak: Party age 2004 per seat less than 15 years 1

Medium: $15-30$ years

Strong: more than 30 years

Regularity of electoral competition/legislative volatility

(Pedersen index last election)

High: volatility less than 20 on Pedersen index (seats) 3

Medium: 20-40 2

Low: more than $40 \quad 1$

Legitimate key forum in political arena:

High: turnout on average more than $66,7 \%$ of registered voters 3

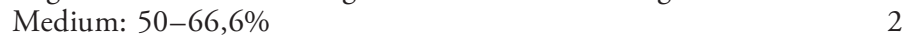

Low: less than $50 \%$

Total institutionalisation score:

Added values divided by three:

High:

Medium:

Low: 


\section{Appendix III:}

Source: own calculation on the basis of Lindberg (2004).

Note: Minor inconsistencies due to rounding off.

\section{Coding Polarisation:}

\section{Opposition boycott per election}

No boycott:

Boycott of some parties:

Main or full opposition boycott:

\section{Electoral violence:}

Completely peaceful:

Isolated violent incidents:

Widespread violence:

Losers' acceptance of results:

All and immediately:

Not at first but later OR some but not all:

Not at all:

\section{Total polarisation score:}

Low: up to 1 problematic incident per election

Medium: $>1$ and $<2$ problematic incidents per election

High: $\quad 2$ and more problematic incidents per election

\section{Appendix IV:}

Note: Democratic party systems are expected to be (1) moderately fragmented (neither dominant nor pulverised), (2) low polarised in terms of inter-party confrontation and (3) highly institutionalised. A best system requires that these three characteristics match, partly if two do match. If these three characteristics do not match we have a worst system, partly if two do not match. 


\title{
Paths of Electoral Reform in Africa
}

\author{
Christof Hartmann
}

\section{Why electoral reform matters}

Elections have been among the most contested elements of recent analysis of African politics. ${ }^{1}$ Assessment of their function and relevance for democratization varies as does the evaluation of the technical quality of the electoral processes. The international media attention focusing on electoral malpractices in places like Zimbabwe has obscured the astonishing new 'normality' of electoral politics in many parts of the continent: a growing number of African political elites seem to have accepted elections (out of conviction or necessity) as the central mechanism for the regulation of political competition.

Among the many factors that explain this surprising breakthrough of competitive electoral politics in Africa is the quality of electoral institutions, i.e. the rules and provisions that were applied in elections. Elections in many African states have not only become more competitive, they have increasingly been organized in a more professional and transparent way. ${ }^{2}$ Better electoral rules do not make a democracy survive but institutional theory assumes that they critically affect the political strategies of the actors struggling for power and representation in the new democratic regimes. ${ }^{3}$ As political actors (both in government and opposition) have become aware of the 'menu of manipulation' (Mozaffar and Schedler 2002), few doubt the need for further reforms of electoral institutions.

1. The author would like to thank Matthias Basedau and two anonymous referees for helpful comments on an earlier draft of this chapter.

2. There is indeed growing criticism in donor circles that procedurally perfect electoral regimes, financed largely from the outside, are neither institutionally nor financially sustainable (see Ottaway and Chung 1999 for an early statement of that position).

3. Incumbent parties have been and may still be the main channel of manipulating elections, but a look at electoral institutions is helpful in order to understand why overwhelming patronage capacities transform into electoral victories in some cases but not in others. 
Our understanding of African electoral institutions is still limited. Many scholars have focused more on the effects of electoral rules on political stability, democracy, governance or development than on why these institutions were established. Institutions do change, but there may be constraints on purposeful design. Why is it that constitution- and decisionmakers often ignore the theoretical insights about the 'best institution'? It is this concern with institutional design and change that has guided the research. Why did African countries opt for different types of electoral rules when they redemocratized and why did some countries subsequently modify these provisions in more or less radical ways? It is argued that reforms of electoral institutions rarely deviate from the historical path of electoral regime taken before or at independence. This hypothesis is tested for a specific but particular important sub-set of electoral rules, the electoral system change. A sober assessment of path-dependent change and the windows of opportunity needed for a path-departing change might also help political engineers and researchers using electoral rules as independent variables to build their analysis on empirically sound ground.

Two equally important but conceptually distinct sets of electoral rules have to be distinguished. Most analyses have concentrated on the broad institutional framework of what has been named electoral governance (Mozaffar and Schedler 2002), i.e. the administrative process of registering voters and candidates, organizing the ballot, regulating electoral campaigns and party financing, establishing codes of conduct for candidates and electoral observers, counting votes and handling electoral complaints. The autonomy of formal election management bodies has thus been identified as a major variable explaining democratic performance and regularity of electoral processes.

At a somewhat different level, the analysis of electoral systems has emerged as a closely related field of research. In a more narrow understanding it is concerned with the way in which voters express political preferences for a party or a candidate; and with the method whereby votes are translated into parliamentary seats or into governmental offices. In this regard the analysis of electoral institutions has focused primarily on the effects of the differing mostly inherited parliamentary electoral systems (e.g. why proportional representation has proved to be superior to plurality, cf. Barkan 1995 and Reynolds 1995). Electoral systems are then treated as independent variables that influence, for example, the representation of women or minority groups. Other authors have concentrated on the theoretical crafting of electoral systems best suited to the exigencies of deeply divided socie- 
ties (see Bogaards in this volume and Horowitz 1991). These contributions often suggest that reform processes towards the intended ideal results could be rationally and incrementally engineered.

What seems to be lacking from the literature is a closer look at the empirical processes of electoral reform that have been undertaken in many African countries since the latest spread of democratisation in the early 1990 s, i.e. the reversal of the perspective: electoral rules as the dependent, not independent variable.

Interestingly, there were many and often successful reforms of aspects of electoral governance (Mozaffar 2002). In contrast to the situation in established democracies, the independence, efficiency and neutrality of African electoral administrations cannot be assumed as given. In most cases, incumbent heads of state and previous single parties did participate in founding elections. There is no doubt that this specific context led to an initial emphasis on providing a (more) level playing field by modifying and creating different institutions of electoral administration. The electoral acts and additional decrees of many states have been thoroughly modified and have often become lengthy volumes with detailed provisions on the composition of electoral commissions at different geographical layers, or on the presence of party agents in polling booths.

Increasing international attention and 'better' electoral governance have led to situations where electoral fraud has to be more sophisticated and has been shifted to the manipulation of legal and constitutional rules, often in procedurally impeccable ways (especially where dominant parties have super-majorities in parliament). Yet, the quality of electoral processes in many African countries has improved over the last decade to an extent that makes the blatant and crude rigging of elections ten years ago appear as belonging to a previous era. Oppositional electoral victories in Côte d'Ivoire or Kenya became possible only after the radical overhaul of existing electoral administrations.

Reforms related to the electoral system have been, on the contrary, much less on the agenda of both domestic and international reform lobbies. This is interesting as such reforms have featured prominently in the political and scientific debate in Central and Eastern Europe and South East Asia. In Africa the discussion over suitable types of electoral systems has only very recently begun in some countries and - as we will see below - successful reforms have been few and mostly limited to minor elements and rarely 
led to a fully-fledged change in the overall electoral formula. 'Successful' will mean the successful modification of the rules and not the success in terms of specific (desirable) outcomes such as political stability, or the fair representation of all political groups.

The next section will briefly introduce the main types of electoral systems that are generally used in the comparative literature. The two successive empirical sections present data for reforms of the electoral systems in all Sub-Saharan states first at the moment of founding elections/democratization and then for subsequent developments. In the concluding section - taking up a line of reasoning from historical institutionalism (North 1990; Thelen 1999) - it will be argued that institutional legacies and pathdependency explain to a large extent the occurrence of reforms and type of electoral system eventually introduced. Strategic calculations by elite actors play a decisive role in determining the electoral systems, but contextual factors set the menu for choice and determine the design alternatives. ${ }^{2}$

\section{Types of electoral systems}

Until recently many electoral reform debates seemed to suggest that there were only two types of electoral systems, and that countries had to choose between plurality systems on one side and proportional representation (PR) systems on the other. In reality, taking a broader perspective, we see not two, but an enormous variety in world-wide parliamentary electoral systems. We have not only some systems where both plurality and PR elements are combined, but even within the same basic type of electoral system, there can be a multiplicity of ways in which various technical elements are combined. Such technical elements of parliamentary electoral systems include the size of constituency, the form of candidacy and ballot structure, and the formula for converting votes into seats. ${ }^{3}$ The international schol-

1. For lack of space we exclude from our analysis here presidential electoral systems where debate (especially about term limits for presidents) has been intense and polarized.

2. For a similar approach in understanding electoral reform in post-communist Europe see Birch et al. (2001).

3. For details on these technical elements cf. Nohlen (1996) and the Glossary in Nohlen et al. (2001). If we want to analyze the political effects of electoral systems (i.e. the probability of parties or candidates being elected or not) we should not simply look at the overall type of electoral system (say a PR system) but at the combination of the specific technical elements which may be responsible for producing certain political consequences of an electoral system. 
arship has nevertheless agreed to speak of three basic groups of electoral systems: majoritarian, PR, and combined systems.

The standard type of majoritarian systems is the plurality system or firstpast-the-post system, normally in single-member constituencies (SMCs), or in small multi-member constituencies (MMCs). The candidate who receives the most votes in each constituency is elected. It is applied in Great Britain, and most former British colonies still use the plurality system in SMCs. In the absolute majority system in single or small multi-member districts in the case of no candidate receiving an absolute majority of votes on polling day, a second round is held where both the strongest candidates or all candidates that have reached a certain threshold (of say ten or 15 per cent) qualify for a decisive run-off. This latter system is used as the electoral system in most direct presidential elections in Africa. ${ }^{1}$

Proportional representation (PR) systems may be applied in a national constituency or in several multi-member constituencies. All parties are required to present a list of candidates to the electorate giving as many candidates as there are seats to be filled in the constituency. Parties receive seats in proportion to their overall share of the vote. Winning candidates are taken from the lists in the order of their respective positions. A pure PR system means one national constituency and no artificial thresholds in force. Electoral thresholds mean that parties have to reach a fixed percentage of valid votes in order to be considered in the distribution of seats. If PR is applied in variable MMCs the size of constituencies is of vital importance for the outcome. The smaller the size of the electoral district, the less the degree of proportionality of the electoral system. A PR system in small multi-member constituencies - say three or four seats - produces high distortion effects on the degree of proportionality, and is therefore actually - with regard to the effects - more of a majoritarian electoral system than a PR system.

The advantages and disadvantages of electoral systems have often been discussed with regard to the normative functions that such a system should fulfil. It is generally assumed that electoral systems perform multiple functions, including those which follow (Nohlen 1996: 94ff). Representation of

1. Another type of absolute majority electoral system, the Alternative Vote (in single or small multi-member constituencies) requires electors to rank the candidates in the order of their choice, marking a one for their favoured candidate, a two for their second choice and so on. If no candidate obtains 50 per cent of the first preferences, the second or third preferences are transferred until one of the candidates reaches over 50 per cent. The winner might thus not necessarily be the candidates with the plurality of first preferences. 
interests, especially of minorities as well as of all relevant groups is one and the electoral system should also be fair in the sense of proportional representation of parties and candidates according to the share of votes they received (proportionality). Concentration of interests relates to the aggregation of social interests in a way, which enables political institutions to act. A high number of parties is often understood as problematic, especially in new democracies as they might lead to institutional deadlock: it is highly improbable that unstable governments are efficient. Simplicity is the third criterion, as the system should not be too difficult for a less educated or even illiterate electorate to understand and for an administration to handle without risking loss of transparency. As regards the criterion of participation and accountability, the key question is whether the voter can choose between political parties (party-list vote) or between individual candidates (personalised vote), and whether representatives are elected as individuals (in a constituency or through a non-closed party list) or through a closed party list. It is often assumed that a personalised form of voting and/or constituency representation improves the voter-representative relationship through increasing the participation of the votes and/or improving the accountability of the representatives. From this perspective, closed party lists are regarded as undesirable.

Different electoral systems satisfy these functional demands in different ways. Majority systems concentrate on achieving a governing majority of one party or of a party alliance. The objective of proportional representation is, on the contrary, to achieve an inclusive parliamentary representation of the social forces and political opinions prevailing in the population. It is, however, important to stress that no electoral system fulfils all of the requirements completely. Thus the choice of an electoral system involves difficult trade-offs: for example, the requirements of ensuring adequate and fair representation and an effective parliament based on an appropriate (i.e. small) number of parties may not be reconciled. ${ }^{1}$ The importance attached to these different functional demands depends largely on the particular historical, social and political context in which an electoral system has to operate, and on the views and interests of the political players who decide which system to implement. In a system undergoing democratisation inclu-

1. To give another example: the demand for increasing the degree of participation within an electoral system that simultaneously ensures fair representation inevitably leads to a more complicated system. In such a case the demand for a simple and easily comprehensible electoral system may not be satisfied. 
sion of all relevant political groups in parliament could thus be regarded as more important than achieving a stable government majority.

The emergence of the third group of electoral systems, the combined (sometimes called 'mixed') electoral systems has to be seen in this same perspective. The underlying rationale is apparently to design electoral systems out of the 'best of both worlds' (Shugart and Warttenberg 2001), i.e. to cumulate the virtues of majority rule and proportional representation (PR). In this sense, the advantages of combined electoral systems are twofold: they are believed to produce more inclusive outcomes than 'pure' majority systems of the British type, thus meeting better the normative criterion of representation. Simultaneously, combined systems ought to perform better than pure PR systems in generating parliamentary majorities according to the concentration function. There are again many options of combining majority rule and PR elements in one electoral system; and one has to distinguish at least three types of such combined systems (Grotz 2002).

Under a Segmented System (also known as 'Parallel System'), the seats of a parliamentary chamber are allocated by two completely separated procedures. For a fixed portion of seats, proportional representation in large (often national) multi-member constituencies is applied; for another portion of seats, MPs are elected in single-member constituencies by the plurality (or absolute majority) rule. As these two parts are not connected by any means and their respective electoral formulas are also applied in a 'parallel' manner, the political effects of the entire system tend to be in-between majority rule and PR, regarding both the representation and concentration functions. ${ }^{1}$ Contrary to the segmented system, the parts of a Compensatory System are inter-connected insofar as the unsuccessful votes of the majoritarian part are additionally taken into account in the allocation of the PR seats. Technically, this can be achieved, for example, by subtracting the votes that all winners in the single-member districts have obtained, from the total party votes at the national level. By this procedure, smaller parties are partially compensated for their disadvantage in the distribution of the majority seats. Since existing compensatory systems are few (Italy, Hungary) and enormously complex, the relevant effects are very difficult to predict. They obviously depend to a large extent on the numerical relationship between the plurality part and the PR part of the system.

1. This theoretical argument of a 'medium effect system' presupposes a 50:50 distribution of majority and PR seats. In the case of greater deviations in one or other direction, the segmented system will effectively come closer to the relevant 'pure' type. 
Finally, the Mixed-Member Proportional System (MMPS) is structurally different from both other types. In this system, the total number of seats are allocated by PR, i.e. the votes obtained by parties at the national level constitute the only basis for determining, proportionately, the seat share of parties. As in both segmented and compensatory systems, a fixed number of seats (usually half of the seat total) is allocated according to the plurality system in single-member constituencies (SMCs). Yet, these winning SMC candidates - usually affiliated to a certain party - are then subtracted from the party's seat total, determined in a first step by the list votes according to PR at national level. Thus, the more district mandates a party wins, the fewer list seats it will receive. The results in the single-member constituencies only determine who among the single-member district and party-list candidates of a given party receive seats. The MMPS is thus in effect a 'personalised' system of proportional representation, and it performs best among all combined systems with regard to the representation function. If a party wins more direct mandates than it was entitled to under the PR distribution of seats, it is allowed to keep these extra seats, and the size of the parliament is increased accordingly (so called surplus or overhangmandates).

In analyzing electoral reforms we should, however, bear in mind that electoral reforms are not technical and abstract processes but reflect the strategic interests of the political actors involved in the reform process. 'Electoral systems are rarely designed, they are born kicking and screaming into the world out of a messy, incremental compromise between contending factions battling for survival, determined by power politics' (Norris 1997: 4). While consultants (and philosophers) might give their advice for a best electoral system taking into account the different normative criteria mentioned above, politicians may strive for an electoral system that is not inclusive but exclusive, as long as they belong to the few winners, and that increases the power of party leaders to the detriment of transparency and the participation of voters.

\section{Democratization and electoral system choice}

What explains the choice of electoral systems in the Sub-Saharan African states? It is a conventional wisdom that these states inherited their constitutional systems and political institutions from the former colonial rulers. But the French and British had also initiated timid steps towards political liberalization in the later phase of colonial administration that created dis- 
Table 1: Electoral systems applied in the first competitive elections

\begin{tabular}{|c|c|c|c|c|}
\hline $\begin{array}{l}\text { Electoral } \\
\text { system }\end{array}$ & $\begin{array}{l}\text { Former British } \\
\text { colony }\end{array}$ & $\begin{array}{l}\text { Former French } \\
\text { colony }\end{array}$ & $\begin{array}{l}\text { Former Portu- } \\
\text { guese colony }\end{array}$ & Other \\
\hline $\begin{array}{l}\text { Plurality in } \\
\text { MMC }\end{array}$ & Mauritius $^{\mathrm{a}}$ & Djibouti & & \\
\hline $\begin{array}{l}\text { Plurality } \\
\text { in SMC }\end{array}$ & $\begin{array}{l}\text { Botswana } \\
\text { Gambia } \\
\text { Ghana } \\
\text { Kenya } \\
\text { Lesotho } \\
\text { Malawi } \\
\text { Swaziland } \\
\text { Tanzania } \\
\text { Uganda } \\
\text { Zambia } \\
\text { Zimbabwe }\end{array}$ & Côte d'Ivoire ${ }^{\mathrm{b}}$ & & Ethiopia \\
\hline $\begin{array}{l}\text { Othermajori- } \\
\text { tarian systems }\end{array}$ & & $\begin{array}{l}\text { Cameroon }^{\mathrm{c}} \\
\text { Madagascar }^{\mathrm{d}}\end{array}$ & & \\
\hline $\begin{array}{l}\text { Absolute } \\
\text { majority in } \\
\text { SMC/ MMC }\end{array}$ & & $\begin{array}{l}\text { CAR } \\
\text { Chad } \\
\text { Comoros } \\
\text { Gabon } \\
\text { Mali } \\
\text { Mauritania } \\
\text { Togo }\end{array}$ & & Sudan \\
\hline Segmented & Seychelles & $\begin{array}{l}\text { Guinea }^{\mathrm{e}} \\
\text { Senegal }^{\mathrm{f}}\end{array}$ & & \\
\hline $\begin{array}{l}\text { PR in small } \\
\text { MMC }\end{array}$ & & $\begin{array}{l}\text { Burkina Faso } \\
\text { Niger }\end{array}$ & $\begin{array}{l}\text { Cape Verde } \\
\text { Guinea-Bissau } \\
\text { Sao Tomé }\end{array}$ & $\begin{array}{l}\text { Burundi } \\
\text { Equatorial } \\
\text { Guinea }\end{array}$ \\
\hline $\begin{array}{l}\text { PR in medium } \\
\text { and large MMC }\end{array}$ & & Benin & $\begin{array}{l}\text { Angola } \\
\text { Mozambique }\end{array}$ & \\
\hline Pure PR & Sierra Leone & & & $\begin{array}{l}\text { Liberia } \\
\text { Namibia } \\
\text { South Africa }\end{array}$ \\
\hline
\end{tabular}

The table is drawn from Nohlen, Krennerich and Thibaut (1999) and slightly modified by the author. The table does not include Eritrea, Rwanda, DR Congo and Somalia where no elections were held during the 1990s.

${ }^{a}$ Individual candidacies; additional best loser seats.

${ }^{\mathrm{b}}$ Including some multi-member constituencies.

${ }^{c}$ Plurality in SMCs and bonus system in small MMCs (list with absolute majority gets all seats; if none, plurality winner gets half of seats plus proportional distribution of remaining seats among all other lists).

${ }^{\mathrm{d}}$ Plurality in SMCs, PR system in Two- and Three-Member Constituencies.

${ }^{\mathrm{e}}$ Plurality seats in SMCs.

${ }^{\mathrm{f}}$ Plurality seats in SMCs and small MMCs. 
tinct institutional legacies. Upon independence the new African regimes were inclined to continue electoral rules that had brought them to power in the pre-independence elections. This might explain why many Francophone countries did not implement the absolute majority electoral system then in use in the French 5th Republic, but the plurality system in multimember constituencies applied previously in the French territories in Africa. The 'second wave' of democratisation in the late 1970s that brought the reintroduction of (semi-) competitive elections in Burkina Faso (then Upper Volta) and Senegal went along with the application of PR systems. ${ }^{1}$ British colonies invariably introduced or continued with the plurality or first-past-the-post system in single-member constituencies.

In the early 1990 s nearly all African states re-introduced competitive elections and liberalized their political systems. In some cases this meant the writing of new constitutions and electoral laws, in other cases it simply amounted to reaffirming the validity of existing but never seriously implemented electoral institutions. Table 1 shows the interesting pattern of electoral system development in the 1990s. Countries are located according to the electoral system type that was in use at the time of the re-introduction of competitive politics. The table clearly shows the important role of institutional legacies. ${ }^{2}$ The first introduction of competitive politics in the final phase of colonial rule marked the critical juncture. At the time of democratization and national conferences this initial choice was confirmed with some rare exceptions as pointed out below. Under the conditions of high uncertainty and strong time pressure, the adoption of the most obvious, i.e. the inherited model, may have short-circuited decision-making when compromise seemed otherwise unattainable.

Most former British colonies stuck to the plurality system. In Ghana, Kenya, and Zambia the electoral system was a non-issue in the liberalization process. Zambia and Tanzania had applied plurality systems in semicompetitive elections during single-party rule while Gambia, Ghana, Nigeria and Uganda had held multi-party elections under this electoral formula at various periods of their independent political history. Three former British colonies had opted or opted now for different formulas: Mauritius,

1. For lack of space it is impossible to account for variance in the development of electoral systems during the authoritarian phases. For an overview see Hermet et al. (1978) and Nohlen; Krennerich and Thibaut (1999).

2. Mozaffar (1998), based on a similar theoretical statement, has proposed a threefold distinction into an 'Anglophone pattern', a 'Francophone pattern' and a 'Southern African pattern'. 
the Seychelles and Sierra Leone. The two Indian Ocean states of Mauritius and the Seychelles had departed from the plurality system long before the democratic wave of the 1990s. While the British pre-independence Banwell Commission in Mauritius had opted for a PR system, the two biggest pro-independence parties carried through the majority system still in use with the best loser seats as a compensation for the adherents of PR. The segmented system in the Seychelles was introduced in 1975 when party majorities in parliament 'manufactured' by the plurality system menaced the political stability of the island. ${ }^{1}$ Sierra Leone had used the plurality system since independence, but the high number of internally displaced persons by the end of the civil war and the influence of United Nations personnel in the elaboration of the electoral law made the introduction of a PR system possible. The pattern in the former Portuguese colonies is even more clear-cut. All five states introduced the Portuguese electoral system of PR with the d'Hondt formula. ${ }^{2}$

Developments in the former French colonies were less homogenous. The majority opted for the French electoral system of absolute majority with Chad, Mali and Mauritania applying it in single- and multi-member constituencies (corresponding to the administrative units). Djibouti, Côte d'Ivoire, Cameroon and Madagascar stuck to the original French colonial system of plurality list systems in predominantly small MMCs and SMCs with Cameroon and Madagascar applying hybrid systems that differentiate electoral formulas according to the size of the constituency (see footnotes ${ }^{c}$ and ${ }^{\mathrm{d}}$ under Table 1). Three former French colonies (Benin, Burkina Faso and Niger) introduced PR systems while the remaining two (Guinea, Senegal) combined the traditional plurality system with PR lists at the national level. ${ }^{3}$ These differences are in many cases the result of different institutional arrangements of previously authoritarian regimes, especially their political organization of social and ethnic interests (Côte d'Ivoire or Madagascar) as well as the consequence of the mode of system change: the tabula rasa of

1. The compensatory seats were the result of an extra-legal deal between the incumbent party of the day and the opposition. It did not prevent the opposition form staging a military coup (see Taagepera 1998: 82). Interestingly, the electoral system was subsequently maintained throughout the different regime changes.

2. Similarly, Burundi and Equatorial Guinea introduced the electoral system of their former colonial rulers Belgium and Spain.

3. In Senegal this segmented system had already been engineered by the Socialist Party already during the 1980s. For a detailed account of the reasoning behind it see Mozaffar and Vengroff (2002). 
National Conferences with a level playing field for all actors (Benin, Niger) favoured the introduction of inclusive electoral formulas such as PR while top-down decision-making in Cameroon or Chad led to the adoption of strongly majoritarian electoral systems.

Let us also have a look at the right column. With Liberia, Namibia and South Africa three countries with an Anglo-American tradition had applied plurality system in SMCs throughout their electoral history. In Namibia and South Africa both the liberation movements and the former Apartheid rulers had a strong interest in PR, although for different reasons: while the liberation movements wanted to secure parliamentary seats for formerly exiled leaders and also guarantee multi-racial representation, the white-dominated parties rightly feared complete marginalization under a plurality formula in SMCs. Liberia switched the electoral formula for the same reason as mentioned above in the case of Sierra Leone: the reconstruction process in the wake of the civil war forced the political actors to opt for the least territorial electoral system, i.e. PR in a single national constituency. This allowed voters to vote without registration in specific constituencies.

\section{Consolidation and electoral reforms}

What happened to electoral systems after the first competitive elections? The following tables show subsequent electoral system change for all countries in the four main institutions: electoral formula (plurality, PR et al), assembly size, district size and the legal threshold applied in constituencies. The time frame begins with the first contested elections, which in some countries took place before the start of continent-wide democratization in the early 1990s.

The empirical evidence shows that few states in this group introduced major changes in their electoral systems. Most of the modifications refer to the size of the assembly which has minor effects under the plurality formula. Artificial thresholds exist only in PR systems. Two countries stand out: Sierra Leone kept the PR system, but switched to fourteen MMCs instead of the single national constituency for the 2002 elections; Lesotho became, in 2002, the first African country to introduce a Mixed-Member Proportional System. Despite this apparently strong trend to stick to the plurality system debates in many countries show serious efforts to introduce variants of combined systems. Ghana's Committee of Experts and Tanzania's Constitutional Commission proposed a segmented system in the 1990s, but the 
Table 2: Electoral system change in the former British colonies

\begin{tabular}{|c|c|c|c|c|c|}
\hline Country & Elections & $\begin{array}{l}\text { Electoral } \\
\text { formula }^{a}\end{array}$ & $\begin{array}{l}\text { Assembly } \\
\text { size }^{\mathrm{b}}\end{array}$ & $\begin{array}{l}\text { District } \\
\text { size }^{c}\end{array}$ & $\begin{array}{l}\text { Legal } \\
\text { threshold }\end{array}$ \\
\hline \multirow[t]{4}{*}{ Botswana } & $1965-69$ & $\mathrm{P}$ in $\mathrm{SMC}$ & $31(+6)$ & 1 & - \\
\hline & $1974-79$ & & $32(+6)$ & & \\
\hline & $1984-89$ & & $34(+6)$ & & \\
\hline & 1994-99 & & $40(+7)$ & & \\
\hline \multirow[t]{4}{*}{ Gambia } & $1966-82$ & $\mathrm{P}$ in $\mathrm{SMC}$ & $32(+6)$ & 1 & - \\
\hline & $1987-92$ & & $36(+14)$ & & \\
\hline & 1997 & & $45(+4)$ & & \\
\hline & 2002 & & $48(+5)$ & & \\
\hline \multirow[t]{2}{*}{ Ghana } & $1969-79$ & $\mathrm{P}$ in SMC & 140 & 1 & - \\
\hline & $1992-2000$ & & 200 & & \\
\hline \multirow[t]{2}{*}{ Kenya } & 1992 & $\mathrm{P}$ in SMC & $202(+10)$ & 1 & - \\
\hline & 1997-2002 & & $210(+12)$ & & \\
\hline \multirow[t]{3}{*}{ Lesotho } & 1993 & $P$ in SMC & 60 & 1 & - \\
\hline & 1998 & & 80 & & \\
\hline & 2002 & MMP & $\begin{array}{l}80 \\
+40 \\
\end{array}$ & $\begin{array}{l}1 \\
40(\mathrm{NC})\end{array}$ & - \\
\hline \multirow[t]{2}{*}{ Malawi } & 1994 & $\mathrm{P}$ in $\mathrm{SMC}$ & 177 & 1 & - \\
\hline & 1999 & & 193 & & \\
\hline Mauritius & $1967-2000$ & $\begin{array}{l}\mathrm{P} \text { in } 3 \mathrm{MC}+ \\
\text { Best Loser }\end{array}$ & $\begin{array}{l}62 \\
+8 \\
\end{array}$ & $\begin{array}{l}3(+2 \times 2) \\
1\end{array}$ & - \\
\hline \multirow[t]{4}{*}{ Nigeria } & 1964 & $\mathrm{P}$ in $\mathrm{SMC}$ & 469 & 1 & - \\
\hline & $1979-83$ & & 450 & & \\
\hline & 1992 & & 589 & & \\
\hline & 1998-2003 & & 360 & & \\
\hline \multirow[t]{2}{*}{ Seychelles } & 1993 & $\begin{array}{l}\text { P in SMC } \\
\text { PR (Hare) }\end{array}$ & $\begin{array}{l}22 \\
+11\end{array}$ & $\begin{array}{l}1(22) \\
11(\mathrm{NC})\end{array}$ & $\overline{8} \%$ \\
\hline & 1998-2002 & $\begin{array}{l}\text { P in SMC } \\
\text { PR (Hare) }\end{array}$ & $\begin{array}{l}25 \\
+ \text { up to } 10(9)\end{array}$ & $\begin{array}{l}1(25) \\
10(\mathrm{NC})\end{array}$ & - \\
\hline \multirow[t]{3}{*}{ Sierra Leone } & 1986 & $\mathrm{P}$ in $\mathrm{SMC}$ & 105 & 1 & $-\ldots$ \\
\hline & 1996 & PR (Hare) & $68(+12)$ & 68 (NC) & $5 \%$ \\
\hline & 2002 & & $112(+12)$ & $8(14)$ & \\
\hline Tanzania & $1995-2000$ & $\mathrm{P}$ in SMC & $231(+64)$ & 1 & - \\
\hline \multirow[t]{2}{*}{ Uganda } & 1980 & $\mathrm{P}$ in $\mathrm{SMC}$ & 126 & 1 & - \\
\hline & 1996-2001 & & $214(+91)$ & & \\
\hline \multirow[t]{2}{*}{ Zambia } & $1973-1988$ & $\mathrm{P}$ in $\mathrm{SMC}$ & 125 & 1 & - \\
\hline & 1991-2001 & & $150(+8)$ & & \\
\hline \multirow[t]{2}{*}{ Zimbabwe } & 1980-1985 & $P$ in $S M C$ & $\begin{array}{l}100 \text { (sep. } \\
\text { roll) }\end{array}$ & 1 & - \\
\hline & 1990-2000 & & $120(+30)$ & 1 & \\
\hline
\end{tabular}

General note: for each country subsequent lines evidence only the changes. 
${ }^{a} \mathrm{P}$ in SMC = Plurality in Single Member Constituencies; MMP $=$ Mixed-Member Proportional System; P in 3MC = Plurality in Three-Member Constituencies; PR = Proportional Representation.

${ }^{\mathrm{b}}$ Figures in brackets refer to additionally appointed seats.

${ }^{c}$ Figures in brackets refer to number of constituencies (where applicable); NC = National Constituency.

proposals were eventually abandoned; the Constitution of Kenya Review Commission proposed in their $2002 \mathrm{draft}$ constitution an MMP with 210 + 90 seats (Art. 107, Draft Constitution; the decision about constitutional reforms is still pending); the Sachs Commission in Mauritius similarly proposed a segmented system (with $68+30$ seats) to be applied in the parliamentary elections in 2005.

In the Francophone countries there have been few major reforms of electoral systems. Again, most of the changes are limited to modifying the size of the assembly. As a rule, only those (more democratic) states that had introduced new electoral systems in the early 1990s did experiment with further modifications: Benin drastically reduced the size of its PR constituencies in order to counter the fragmentation of its party system; Burkina Faso plagued by the opposite phenomenon of a hyperdominant former single party created a two-tiered PR system with a national list accompanying small MMCs in order to allow the opposition a fairer representation in the National Assembly. Reforms in Madagascar and Chad were on the contrary intended to strengthen the majoritarian effect of their electoral systems. Chad switched from absolute majority to plurality in mostly - SMCs while Madagascar reduced the size of its MMCs with an average district size of 1.3 .

Table 3 is, however, silent about failed efforts to reform electoral systems. In the wake of the first military coup in Ivory Coast the Constitutional Convention proposed to switch from a plurality to absolute majority system keeping the relatively unbalanced distribution of constituencies. The military regime (with support of the then opposition party FPI) in the end retained the previous formula, but modified the boundaries and increased the number of consituencies. In Mali, a country with a volatile and unstructured party system the political elites agreed before the 2002 elections to introduce a segmented system along the lines of the Senegalese example adding 40 seats elected from a national list to the 110 elected members from small MMCs by the absoultue majority system. In a rather curious development the Constitutional Court of Mali blocked this electoral reform arguing that the segmented system violated the constitutional principle of equality. Local observers hinted that the judges had apparently completely 
Table 3: Electoral system change in the former French colonies

\begin{tabular}{|c|c|c|c|c|c|}
\hline Country & Elections & Electoral formula ${ }^{a}$ & $\begin{array}{l}\text { Assembly } \\
\text { size }^{\text {b }}\end{array}$ & $\begin{array}{l}\text { District } \\
\text { size }^{c}\end{array}$ & $\begin{array}{l}\text { Legal } \\
\text { threshold }\end{array}$ \\
\hline \multirow{2}{*}{ Benin } & 1991 & \multirow{2}{*}{ PR (Hare) } & 64 & $\varnothing 10.6(6)$ & - \\
\hline & 1995-2003 & & 83 & $\emptyset 4.6(18)$ & - \\
\hline \multirow{4}{*}{ Burkina Faso } & 1992 & \multirow{4}{*}{ PR (Hare) } & 107 & $2-7(30)$ & - \\
\hline & 1997 & & 111 & $1-11(45)$ & \multirow{3}{*}{-} \\
\hline & 2002 & & 90 & $2-10(13)$ & \\
\hline & & & 21 & $21(\mathrm{NC})$ & \\
\hline Cameroon & $1992-2002$ & $\begin{array}{l}\text { Majority system in } \\
\text { SMC/MMC }\end{array}$ & 180 & $\begin{array}{l}1(73) \\
2-7(?)\end{array}$ & $\begin{array}{l}5 \% \text { in } \\
\mathrm{MMC}\end{array}$ \\
\hline \multirow{2}{*}{ CAR } & 1993 & \multirow{2}{*}{$\mathrm{AM}$ in SMC } & 85 & 1 & \multirow{2}{*}{-} \\
\hline & 1998 & & 109 & & \\
\hline \multirow[b]{2}{*}{ Chad } & 1997 & $\mathrm{AM}$ in SMC/MMC & 125 & $\begin{array}{l}1(25) \\
2-5(34)\end{array}$ & - \\
\hline & 2002 & $\begin{array}{l}\mathrm{P} \text { in } \mathrm{SMC} \\
\mathrm{PR} \text { in } \mathrm{MMC}\end{array}$ & 155 & $\begin{array}{l}1(91) \\
2-4(25)\end{array}$ & - \\
\hline \multirow{2}{*}{ Comoros } & 1993 & \multirow{2}{*}{$\mathrm{AM}$ in $\mathrm{SMC}$} & 42 & \multirow{2}{*}{1} & \multirow{2}{*}{-} \\
\hline & 1996 & & 43 & & \\
\hline \multirow{2}{*}{ Congo } & $1992-93$ & \multirow{2}{*}{$\mathrm{AM}$ in SMC } & 125 & \multirow[t]{2}{*}{1} & \multirow{2}{*}{-} \\
\hline & 2002 & & $129(+8)$ & & \\
\hline \multirow{4}{*}{ Côte d'Ivoire } & $1990-95$ & \multirow{4}{*}{$\mathrm{P}$ in $\mathrm{SMC} / \mathrm{MMC}$} & 175 & $1(141)$ & - \\
\hline & & & & $2-4(34)$ & \\
\hline & 2000 & & 225 & $1(154)$ & \\
\hline & & & & $2-4(20)$ & \\
\hline Djibouti & 1991 & $\mathrm{P}$ in $\mathrm{MMC}$ & 65 & $4-37(5)$ & - \\
\hline Gabon & 1986 & $\mathrm{P}$ in SMC & 105 & 1 & - \\
\hline Guinea & $1995-2000$ & Plurality + PR (Hare) & 114 & $\begin{array}{l}1(38) \\
76(\mathrm{NC})\end{array}$ & - \\
\hline \multirow{3}{*}{ Madagascar } & 1993 & $P+P R($ Hare $)$ & 138 & $1-3(57)$ & - \\
\hline & 1998 & P + PR (Hare) & 150 & $\begin{array}{l}1(82 \\
2(34))\end{array}$ & \\
\hline & 2003 & P + PR (Hare) & 150 & $\begin{array}{l}1(82) \\
2(34)\end{array}$ & \\
\hline \multirow{2}{*}{ Mali } & 1992 & \multirow{2}{*}{$\mathrm{AM}$ in SMC/TMC } & 129 & $1-7(55)$ & - \\
\hline & 1997-2002 & & 160 & $1-7(55)$ & \\
\hline \multirow{2}{*}{ Mauritania } & $1992-1996$ & \multirow{2}{*}{$\mathrm{AM}$ in SMC/TMC } & 79 & $1-2(53)$ & - \\
\hline & 2001 & & 81 & $1-2(53)$ & $10 \%$ (TMC) \\
\hline Niger & 1993-1999 & $\begin{array}{l}\text { PR (Hare) } \\
\mathrm{P} \text { in SMC }\end{array}$ & $\begin{array}{l}75 \\
8 \\
\end{array}$ & $\begin{array}{l}4-14(8) \\
1(8)\end{array}$ & - \\
\hline \multirow{3}{*}{ Senegal } & 1978 & PR (Hare) & 100 & $100(\mathrm{NC})$ & - \\
\hline & $1983-1993$ & $\begin{array}{l}\mathrm{P} \text { in S/MMC } \\
\mathrm{PR} \text { (Hare) }\end{array}$ & $\begin{array}{l}50 \\
70\end{array}$ & $\begin{array}{l}1-5(30) \\
70(\mathrm{NC})\end{array}$ & \\
\hline & 1998-2001 & $\begin{array}{l}\mathrm{P} \text { in S/MMC } \\
\mathrm{PR} \text { (Hare) }\end{array}$ & $\begin{array}{l}70 \\
70\end{array}$ & $\begin{array}{l}1-5(30) \\
70(\mathrm{NC})\end{array}$ & \\
\hline Togo & $1994-2003$ & $\mathrm{AM}$ in $\mathrm{SMC}$ & 81 & 1 & - \\
\hline
\end{tabular}


General note: for each country subsequent lines evidence only the changes.

${ }^{a} \mathrm{P}$ in $\mathrm{SMC}=$ Plurality in Single Member Constituencies; PR = Proportional Representation; $\mathrm{AM}=$ Absolute Majority; TMC $=$ Two-Member Constituencies; MMC = Multi-Member Constituencies.

${ }^{\mathrm{b}}$ Figures in brackets refer to additionally appointed seats.

${ }^{c}$ Figures in brackets refer to number of constituencies (where applicable); NC = National Constituency.

misunderstood the logic of the segmented system taking it for the electoral system applied in Cameroon where the electoral system is different according to the size of the constituency. Such systems had been in use in various phases of French electoral history, and the French Constitutional Court had barred the introduction of such a system for the French Senate elections with the Malian Constitutional Court literally quoting widely from the judgement of the French Court that was commenting on a different electoral formula. Whatever the reasons might have been, the ruling led to the confirmation of the existing electoral formula as any reform would have meant revising the Constitution. ${ }^{1}$

In the remaining countries electoral reform was not on the agenda, with the exception of South Africa. The electoral system in use was the outcome of heated debates in the constitutional reform forums in 1992-93 (Sisk 1995; Lodge 2003), and constituted a provisional compromise. A high profile commission under the leadership of veteran politician van Zyl Slabbert was formed in 2001 to consider evaluative criteria and the pros and cons of the different electoral formulas. The commission produced a report with a majority proposing a change in the electoral system towards PR in smallconstituencies as the pure PR system at national level was considered to be too weak on accountability. A decision on the electoral reform, which was refuted by a dissenting minority in the commission, was eventually postponed and the 2004 elections held under the existing formula. ${ }^{2}$

We might conclude from the collected data that in Africa no 'largescale rewriting of electoral laws' happened such as the process taking place in post-communist Europe between 1989 and 1991 (Birch et al. 2001; Bielasiak 2002). For the most important rule alteration, the electoral formula, there are few successful cases, but nevertheless a clear trend: if change occurs, then it is by introducing combined systems (with parallel rather than

1. This analysis is based on Fomba (2001) and on an interview with Mohammed Traoré, Conseiller Electoral au Ministère du Plan et de l'Intérieur, Bamako, 18 February 2003.

2. The report of the Electoral Task Team is available on the website of the South African Electoral Commission (www.elections.org.za). 
Table 4: Electoral system change in the former Portuguese colonies

\begin{tabular}{|l|l|l|l|l|l|}
\hline Country & Elections & $\begin{array}{l}\text { Electoral } \\
\text { Formula }\end{array}$ & $\begin{array}{l}\text { Assembly } \\
\text { Size }\end{array}$ & District Size & $\begin{array}{l}\text { Legal } \\
\text { Threshold }\end{array}$ \\
\hline Angola & 1992 & $\begin{array}{l}\text { PR } \\
\text { (d'Hondt) }\end{array}$ & $\begin{array}{l}130 \\
90\end{array}$ & $\begin{array}{l}130(\mathrm{NC}) \\
5(18)\end{array}$ & - \\
\hline Cape Verde & $1991-2001$ & $\begin{array}{l}\text { PR } \\
\text { (d'Hondt) }\end{array}$ & 79 & $2-13(19)$ & - \\
\hline $\begin{array}{l}\text { Guinea- } \\
\text { Bissau }\end{array}$ & $1994-1999$ & $\begin{array}{l}\text { PR } \\
\text { (d'Hondt) }\end{array}$ & 102 & $3-6(27)$ & - \\
\hline $\begin{array}{l}\text { Mozam- } \\
\text { bique }\end{array}$ & $1994-1999$ & $\begin{array}{l}\text { PR } \\
\text { (d'Hondt) }\end{array}$ & 250 & $11-54(11)$ & $\begin{array}{l}5 \% \\
\text { nationwide }\end{array}$ \\
\hline $\begin{array}{l}\text { Sao Tomé } \\
\text { \& Principe }\end{array}$ & $1991-2002$ & $\begin{array}{l}\text { PR } \\
\text { (d'Hondt) }\end{array}$ & 55 & $5-13(7)$ & - \\
\hline
\end{tabular}

$\mathrm{PR}=$ Proportional Representation $\mathrm{NC}=$ National Constituency.

Table 5: Electoral system change in the remaining African countries

\begin{tabular}{|c|c|c|c|c|c|}
\hline Country & Elections & $\begin{array}{l}\text { Electoral } \\
\text { Formula }^{\mathrm{a}}\end{array}$ & $\begin{array}{l}\text { Assembly } \\
\text { Size }\end{array}$ & $\begin{array}{l}\text { District } \\
\text { Size }^{\mathrm{b}}\end{array}$ & $\begin{array}{l}\text { Legal } \\
\text { Threshold }\end{array}$ \\
\hline Burundi & 1993 & $\begin{array}{l}\text { PR } \\
\text { (d'Hondt) }\end{array}$ & 81 & $2-9$ & $5 \%$ \\
\hline $\begin{array}{l}\text { Equatorial } \\
\text { Guinea }\end{array}$ & 1993-1999 & PR (Hare) & 80 & (?) & $15 \%$ \\
\hline Ethiopia & $1995-2000$ & $P$ in $S M C$ & 547 & 1 & - \\
\hline \multirow[t]{2}{*}{ Liberia } & 1985 & $\mathrm{P}$ in $\mathrm{MMC}$ & 64 & (?) & - \\
\hline & 1997 & PR (Hare) & 64 & 64 (NC) & $1,56 \%$ \\
\hline Namibia & 1989-1999 & PR (Hare) & 72 & 72 (NC) & - \\
\hline \multirow[t]{2}{*}{ South Africa } & 1989 & $P$ in SMC & $\begin{array}{l}287 \text { (tri } \\
\text { cameral) }\end{array}$ & 1 & - \\
\hline & 1994-99 & $\begin{array}{l}\text { PR (STV- } \\
\text { Droop) }\end{array}$ & 400 & $\begin{array}{l}400(\mathrm{NC}) \\
\text { à } 9 \mathrm{PC}\end{array}$ & $0,25 \%$ \\
\hline
\end{tabular}

General note: for each country subsequent lines evidence only the changes.

${ }^{a} \mathrm{P}$ in SMC/MMC = Plurality in Single Member Constituencies/Multi-Member Constituencies; $\mathrm{PR}=$ Proportional Representation.

${ }^{\mathrm{b}} \mathrm{NC}=$ National Constituency $; \mathrm{PC}=$ Provincial Constituency (seats distributed at provincial list level).

compensatory voting systems). Nevertheless, attempts to fine-tune election rules through partial reforms concerning adjustments in the other regulations (district size, assembly size) have been evident throughout the region over the past decade. 


\section{The path-dependency of reforms}

Attempts at institutional reform lead to different results. Kaiser (2002) distinguishs three types: institutional conservatism ends with the confirmation of the status quo. In the debate about the pros and cons of changing the electoral system the adherents of the current system prevail. In contrast to institutional conservatism the path-dependent institutional reform does lead to reforms, but these remain within the logic of the existing set of rules. The type of path change ends with the adoption of institutions that to a large extent are a departure from the logic of the previous system. While path dependency tries to learn from and build on the country's own institutional history, path change builds on experiences from foreign political systems. The path dependency perspective fits well into the historical institutionalist approach: the actors perceive only those design alternatives that are close to their historical, geographical and cultural area and that are therefore 'compatible' with the given institutional setting. But which of the three logics has prevailed in Sub-Saharan African processes of electoral reform?

In the majority of African countries there has not been any serious reform debate about electoral systems. We could explain this occurrence of non-reform by the general satisfaction of political elites and the population with the current institutional performance. In many countries, however, decision-makers are simply more concerned with reforming critical aspects of the electoral administration first (as in Zimbabwe) before embarking on reform of the electoral system in the more narrow sense (as used here). It has been rightly argued by students and practitioners that institutional reforms might be meaningless as long as the new rules are not or only partially enforced.

In other countries electoral system reform attempts were aborted. 'The predominant forces may stick to the rules inherited from the preceding political regime either by ignorance of alternatives or by rationally balancing the merits of existing rules against the costs and risks of innovation' (Taagepera 1998: 79). In the African contexts of poorly institutionalized and fluid party systems and the scarce systematic knowledge about electoral support for parties and candidates the political consequences of institutional alternatives are notoriously difficult to predict and decision-makers thus face high risks. 'In voting electoral systems into law, parliamentarians determine the mechanism through which they as individuals may or may not be chosen at the next election. It should not surprise us if they tend to be biased in favour of the system that elected them' (Birch et al. 2001: 2). 
In some cases the poor knowledge and distorted interpretations of the institutional alternatives themselves are the obstacle for reforms in the first place. While opposition parties are vocal in asking for segmented systems or full-blown PR, they may forget these claims once they have reached power under existing electoral formulas that are familiar to candidates, campaigners and voters (cf. Kenya after the 2002 elections or Côte d'Ivoire in 2000). Established electoral resources and locally entrenched strongholds are threatened by redrawing of constituencies (Ghana or Tanzania). The role of random events should also not be underestimated, as shown in the case of Mali: the unforeseen and unlikely intervention of the Constitutional Court, based on a misunderstanding of the technical elements, stopped the reform of the electoral system.

Table 6: Outcomes of electoral reform in Sub-Saharan Africa

\begin{tabular}{lll}
\hline $\begin{array}{l}\text { Institutional } \\
\text { Conservatism }\end{array}$ & Path-Dependent Change & Path Change \\
\hline Congo (Brazzaville) & Benin & Liberia \\
Côte d'Ivoire & Burkina Faso & Namibia \\
Ghana & Chad & Sierra Leone \\
Kenya (open) & Guinea & South Africa \\
Mali & Lesotho & \\
Mauritius (open) & Senegal & \\
South Africa (2002-4) & Sierra Leone (2002) & \\
Tanzania & & \\
\hline
\end{tabular}

${ }^{a}$ Only countries that embarked on a meaningful process of institutional reform and then decided to maintain the original set of rules are included.

But what do we make of the group of successful reformers? Path-dependent change is clearly the dominant pattern, often in the form of incremental steps towards smaller constituencies within PR (Benin, Burkina Faso) or the gradual move towards combined systems (Guinea, Lesotho, Senegal). Four countries chose path-change. In South Africa and Namibia a radical change in the overall political dispensation and the emergence of new actors on the scene led to the rare situation where all main actors had a rational interest in departing from the given path and to switch to (nearly) pure PR systems. In Liberia and Sierra Leone path change was less induced by the rational interest of the domestic actors, but caused by pressure from abroad and force majeure in the context of post-conflict emergencies. Interestingly, in both countries some domestic actors asked for a return to the historical path of the plurality system once electoral administration had been brought back to normal. 
Radical path change goes along with the acceptance of risks while riskminimising action leads to path dependency. The Lesotho Congress of Democracy was willing to accept an MMP system under the condition that the 80 existing constituencies were maintained and the number of seats in parliament significantly increased to allow for the introduction of the combined system. From the perspective of the LCD leadership this was a riskminimising strategy as they counted on winning again the SMCs and felt thus assured of staying in power. As the electoral results showed, the LCD would have stayed in power even under a more balanced distribution of party and constituency seats. Actors take more risks the more information is available about the likely effects of the different institutional alternatives. Path change needs a set of rational decision-makers in electoral system reforms who are able to behave strategically and identify their interests in recognizable ways. These conditions are rarely given in the Sub-Saharan context.

There is a second closely related reason why path change is unlikely: decisions about electoral systems are perceived as high-cost decisions that may have dramatic consequences on the distribution of power between political forces and on the political careers of the individual decision-makers. In Sub-Saharan Africa elections are not only about access to political office, but also about economic power. The perceived cost is thus even higher than in established democracies, although the access to prebends may be limited for members of parliament in the mostly presidential systems of government.

Path-dependent reforms minimize the risk for those in power. As demonstrated previously, with regard to their electoral systems, African states still follow the institutional paths designed by their former colonial rulers or are still inspired by the systems adopted nowadays in Portugal, Spain, Great Britain or France. The self-reinforcing logic of path-dependent change makes it highly probable that any reforms will remain within the established main type of electoral system or allow for only incremental steps that gradually transcend the boundaries of the electoral system types.

The family of British-influenced countries with plurality systems show a high resilience of the established rules, especially as the 'manufactured' majorities helped the opposition to win elections in Zambia and Kenya. ${ }^{1}$ So far, only Mauritius, the Seychelles and Lesotho have started to move toward

1. In a fully competitive setting a rational strategy of risk aversion would thus favour a PR system (where the manufacturing of majorities is excluded) over a plurality system. 
combined systems, two of which are among the few parliamentary systems of the continent and where the parliamentary electoral system therefore has a much greater relevance. ${ }^{1}$ Whereas in bigger states such as Ghana, Nigeria or Kenya strong regional parties gain adequate representation even under the plurality system (in the context of homogenous electoral behaviour), the mixed population patterns in the islands and Lesotho have led repeatedly to the virtual parliamentary annihilation of the opposition. ${ }^{2}$ These specific contextual variables might explain why reforms were implemented, although the fate of the Mauritius reforms was very uncertain at the time of writing (end of 2004). In Lesotho, the specific form of MMP allowed the parties to maintain the existing 80 constituencies and thus did not seriously threaten the dominant position of the incumbent Lesotho Congress of Democrats (Elklit 2002). ${ }^{3}$ The French tradition allowed for a larger heterogeneity of electoral systems. But reform debates in Mali or Côte d'Ivoire remained strongly circumscribed by the prevalent Francophone paths: the decision-makers in Abidjan temporarily opted for the absolute majority system which was applied at that time in most neighbouring Francophone states. The Malian elites wanted to follow the Senegalese path. 'Shared contextual factors set the menu for choice, rational calculations ultimately determine what is selected' (Birch et al. 2001:23). ${ }^{4}$ It would be difficult to find stronger empirical evidence for the limited set of institutional options taken into account by decision-makers.

The comparative experience of electoral reforms shows a worldwide historical trend towards more inclusive and mostly proportional representation electoral systems. Once a pure majoritarian (be it plurality or absolute

1. A reform in one of the bigger plurality countries (most likely Kenya) could, however, trigger similar reforms in Tanzania, Zambia or Ghana.

2. In Lesotho, in 1993 one party gained all seats in parliament (with approximately 70 per cent of the votes) and in 1998 all but one seats; in Mauritius, coalitions won all elective seats in 1982, and 57 and 54 out of 62 in 1991 and 2000 respectively; in the Seychelles one party won 85 per cent of the seats with 52 per cent of the votes in the 1974 elections.

3. It might be that the influence of foreign experts and of the South African example had an influence in this decision to depart from the British tradition.

4. The rational calculation of the then dominant party in Mali ADEMA was very similar to the position of Senegal's Parti Socialiste at the time of the introduction of the segmented system: '(1) enable the opposition to secure enough representation to encourage them to stay in the game; but (2) mitigate the prospects of a potential opposition majority in the national legislature and, in particular, (3) discourage opposition coordination behind a single challenger for the presidency' (Mozaffar and Vengroff 2002: 603). 
majority) system has been replaced by a PR system it becomes very difficult to return to majority systems (Nohlen 1996). The 'territorial' concept of politics prevalent in Africa (la politique du terroir) is, however, a huge obstacle for the introduction of pure PR systems or PR with large constituencies as useful as these might be for managing ethnic conflict (Reynolds 1999) or assuring the representation of women and minorities. In Africa these types were implemented only where exiles or international organizations (both lacking a territorial basis) dominated political decisions. But even in South Africa an MMP system was eventually adopted for local elections in $1998 .{ }^{1}$ While the Francophone part of the continent might face the two options of PR in small constituencies or segmented systems, it is very likely that the Anglophone countries will keep their single-member constituencies for some time to come while incrementally introducing combined systems via additional national party lists or MMP. The expectation is for repeated adjustments in the rules of the electoral game, but within the interpretations and boundaries delineated by history.

\section{References}

Barkan, J.D. (1995), 'Elections in Agrarian Societies', Journal of Democracy 6: 4, pp. 106-116.

Basedau, M. (2002), 'Zum Zusammenhang von Wahlsystem, Parteiensystem und Demokratiestabilität in Afrika. Kritische Anmerkungen zum Potenzial von Electoral Engineering', Afrika Spectrum 37: 3, pp. 311-333.

Bielasiak, J. (2002), 'The Institutionalization of Electoral and Party Systems in Postcommunist States', Comparative Politics 34: 2, pp. 189-215.

Birch, S. et al. (2001), Embodying Democracy. Electoral System Design in Post-Communist Europe. Houndmills: Palgrave.

Bogaards, M. (2000), 'Crafting Competitive Party Systems: Electoral Laws and the Opposition in Africa', Democratization 7: 4, pp. 163-190.

Bogaards, M. (2006), 'Electoral Systems, Party Systems, and Ethnicity in Africa', this volume.

Elklit, J. (1999), 'Electoral Institutional Change and Democratization: You Can Lead a Horse to Water, But You Can't Make It Drink', Democratization 6: 4, pp. 28-51.

Elklit, J. (2002), 'Lesotho 2002: Africa's first MMP elections', Journal of African Elections 1: 2, pp. 1-10.

Fomba, B. (2001), 'La Cour Constitutionnelle et la loi organique sur les députés', Revue du Citoyen (Bamako) No.15 (Mars) .

1. In Namibia the introduction of the plurality system for local and regional elections was discussed for years, but eventually only implemented at the regional level. 
Frye, T. (1997), 'A Politics of Institutional Choice. Post-Communist Presidencies', Comparative Political Studies 30: 5, pp. 523-552.

Geddes, B. (1996), 'Initiation of New Democratic Institutions in Eastern Europe and Latin America', in Lijphart, A. and C. Waisman (eds) Institutional Design in New Democracies. Boulder: Westview, pp. 15-41.

Grotz, F. (2002), 'El sistema propocional de composició mixta d'alemanya: un model per la reforma electoral?’ in Reflexions al votant de la Llei Electoral Catalana. Barcelona: Fundació Carles Pi i Sunyer, pp. 7-18.

Hartmann, C. (2002), 'Comparing Electoral Systems. The German Experience', presentation at the Constitution of Kenya Review Commission Workshop on Electoral Systems and Political Parties, 19th-20th March 2002, Nairobi.

Hermet, G. et al. (eds) (1978), Elections without Choice. London: Macmillan.

Horowitz, D.L. (1991), A Democratic South Africa? Constitutional Engineering in a Divided Society. Berkeley: University of California Press.

Kaiser, A. (2002), Mehrheitsdemokratie und Institutionenreform. Verfassungspolitischer Wandel in Australien, Großbritannien, Kanada und Neuseeland im Vergleich. Frankfurt/M., New York: Campus.

Lijphart, A. (1991), 'Constitutional Choices for New Democracies', Journal of Democracy 2: 2, pp. 72-84.

Lodge, T. (2003), 'How the South African Electoral System Was Negotiated', Journal of African Elections 2: 1, pp. 71-76.

Mozaffar, S. (1998), 'Electoral Systems and Conflict Management in Africa. A TwentyEight-State Comparison', in Reynolds, A. and T. Sisk (eds) Elections and Conflict Management in Africa. Washington: United States Institute of Peace Press, pp. 81-98.

Mozaffar, S. (2002), 'Patterns of Electoral Governance in Africa's Emerging Democracies', International Political Science Review 23: 1, pp. 85-101.

Mozaffar, S. and A. Schedler (2002), 'The Comparative Study of Electoral Governance - Introduction', International Political Science Review 23: 1, pp. 5-27.

Mozaffar, S. and R. Vengroff (2002), 'A "whole system” approach to the choice of electoral rules in democratizing countries: The case of Senegal', Electoral Studies 21: 4, pp. 601-616.

Nohlen, D. (1996), Elections and Electoral Systems. New Delhi: Macmillan.

Nohlen, D. et al. (eds) (1999), Elections in Africa. A Data Handbook. Oxford: Oxford University Press.

Nohlen, D. et al. (eds) (2001), Elections in Asia and the Pacific. A Data Handbook. 2 Vols, Oxford: Oxford University Press.

Norris, P. (1995), 'Introduction: The Politics of Electoral Reform', International Political Science Review 16: 1, pp. 3-8.

Norris, P. (1997), 'Choosing Electoral Systems: Proportional, Majoritarian and Mixed Systems', International Political Science Review 18: 3, pp. 292-312.

North, D.C. (1990), Institutions, Institutional Change and Economic Performance. Cambridge: Cambridge University Press. 
Ottaway, M. and T. Chung (1999), 'Toward an New Paradigm', Journal of Democracy 10: 4, pp. 99-113.

Reynolds, A. (1995), 'The Case for Proportionality', Journal of Democracy 6: 4, pp. 117-124.

Reynolds, A. (1999), Electoral Systems and Democratization in Southern Africa. Oxford: Oxford University Press.

Sartori, G. (1994), Comparative Constitutional Engineering. Basingstoke: Macmillan.

Schedler, A. (202), 'The Menu of Manipulation', Journal of Democracy 13: 2, pp. $36-50$.

Shugart, M.S. and M.P. Warttenberg (eds) (2001), Mixed Member Electoral Systems. The Best of Both Worlds? New York: Oxford University Press.

Sisk, T.D. (1995), Democratization in South Africa. The Elusive Social Contract. Princeton: Princeton University Press.

Taagepera, R. (1998), 'How Electoral Systems Matter for Democratization', Democratization 5: 3, pp. 68-91.

Thelen, K. (1999), 'Historical Institutionalism in Comparative Politics', Annual Review of Political Science, pp. 369-404. 


\title{
Electoral Systems, Party Systems and Ethnicity in Africa
}

\author{
Matthijs Bogaards
}

\section{Introduction}

Traditionally, democratization in Sub-Saharan Africa has been linked to fears of spiralling ethnic conflict. Colonial powers used the tribal organization of traditional societies as an excuse to delay the granting of independence, authoritarian African leaders after independence equated multi-party politics with ethnic conflict in a defence of military regimes and one-party states, and when the third wave of democratization reached Africa in the early 1990s, many expressed concern that democratization on the continent would politicize ethnic divisions and result in ethnic violence (ContehMorgan 1997). Whereas there is evidence that ethnic conflict, especially rebellion, hampers democratization (Scarritt et al. 2001), there is no simple causal connection between ethnic diversity and political instability (Barrows 1976) or between liberalisation/democratization and ethnic conflict in Africa (Smith 2000).

Attempts to directly relate social diversity to degree of democracy (Fish and Brooks 2004) ignore the crucial intermediating role of institutions, including the electoral system (De Nevers 1993; Sisk and Reynolds 1998; Saideman et al. 2002). Reilly and Reynolds (1999: 7) observe how 'scholars and policy makers alike have typically given too much attention to social forces and not enough to the careful crafting of appropriate democratic institutions by which those forces can be expressed'. In fact, the design of institutions that help to 'manage ethnic conflict and provide incentives for interethnic cooperation and accommodation' and the building of strong political parties are the main challenges for African democracies, according to Diamond (1997: 28).

This chapter explores how electoral arrangements have been used and can be used in Sub-Saharan Africa to shape the political organization of ethnicity in the emerging party systems of the region. ${ }^{1}$ Electoral system is

1. For analyses of electoral engineering in Africa not directly linked to ethnic conflict management, see Bogaards 2000; Basedau 2002; Hartmann, this volume. 
understood here in the broad sense, including not only the way votes are translated into seats, but also the regulations for party registration and candidate nomination. The analysis covers countries spread over most of the continent, in the present and past. In the process, the chapter will propose corrections to three prevailing conceptions about electoral engineering for conflict management. First, the current preoccupation with electoral systems should not obscure that, in a heterogeneous society, in which people differ from each other in language, religion, colour of skin, or other sociocultural attributes, the choice of electoral system follows from the choice of party-system function, that is, the desired role of the party system as an intermediary between social and political cleavages. Second, the longstanding juxtaposition of plurality elections or first-past-the-post (FPTP) and proportional representation (PR) loses much of its relevance when socio-cultural groups are geographically concentrated, as is the case in Africa. Rather, the menu of choice is between electoral systems that promote aggregation of socio-cultural divisions; facilitate the political translation of ethnic differences; or block the political organization of socio-cultural cleavages. The way in which social cleavages are politically organized, or not, has important implications for ethnic-conflict management and democratic consolidation (see Lijphart 1977, 1985, 2004; Horowitz 1991, 1994, 2003). Third, any discussion of electoral reform should go beyond the main types of electoral system (plurality, majority, proportional representation) and their variants. The challenges of cultural diversity have provoked electoral designs not easily incorporated in traditional classifications of electoral systems (Nohlen 2000; Norris 2004). As this chapter will show, institutional designers in Africa have made very different choices, resulting in a rich diversity of electoral systems on the continent. No attempt can be made here to account for these choices, to analyze in depth their effects, or to do full justice to contextual variables.

\section{Party-system functions}

In Sartori's (1976: ix) words, 'Parties are the central intermediate and intermediary structure between society and government'. Looking at the way parties link society and government, three party-system functions can be distinguished. The party system can aggregate social cleavages, translate social cleavages into political cleavages, or block the politicization of social cleavages. These three party-system functions correspond to the three models of party system that are still at the basis of most party-system typologies: 
the one-party state, a two-party system, and a multiparty system. There is a strong if imperfect correlation between the number of relevant parties (ibid.) and the dominant function of the party system. The one-party state maximizes blocking; the two-party system is thought to be best in achieving aggregation; the multiparty system is most suited to translation.

Table 1: Party system functions and party system models

\begin{tabular}{lll}
\hline Type of party system & No. of relevant parties & Party system funtion \\
\hline One-party & One & Blocking \\
Two-party & Two & Aggregation \\
Multi-party & More than two & Translation \\
\hline
\end{tabular}

The one-party state has been defended as a necessary tool to block the political translation of socio-cultural cleavages through political parties. It was designed to keep social differences out of politics, at least nominally (Bienen 1971). The classic British or Westminster two-party system has the desired function of aggregating cleavages. Because there are only two parties, by necessity they must aggregate a diversity of interests, resulting in broad parties. Proponents of proportionality and a multi-party system such as Lijphart (1977, 1999, 2004) value the translation function for two reasons. First, the political organization of social differences is an intrinsic part of democracy. Second, when such differences are deep and cannot be reconciled at the mass level, their political translation through so-called segmental parties allows for accommodation at the elite level. Chandra (2005) adds a third reason: the politicization of multiple dimensions will promote moderating cross-cutting cleavages. When political parties compete about which social and economic distinctions get political translation, extremist parties are forced to the centre. This process is facilitated by electoral systems that permit fluidity in ethnic identification.

Although the different party-system functions correspond closely to the number of relevant parties and concomitant party-system models, function cannot be reduced to number nor can the number of relevant parties be derived from function. The blocking function is optimized in the one-party state but not restricted to this regime type. And the one-party state can also promote aggregation and allow for intraparty translation. Although the two-party system in general optimizes aggregation, it can also reflect major divisions, as in the case of a bipolar society. Even multi-party systems do not translate all social cleavages: they aggregate and suppress others. 


\section{Choosing a party system (function)}

Although there is increasing attention to the purpose of electoral system design (see Reynolds and Reilly 1997; Horowitz 2003), the starting point for many discussions is still a specific type of electoral system and what it is expected to do, rather than the tasks an electoral system is required to perform in a given society. This chapter reverses the order, arguing that the choice of electoral system is only of second order importance. The first thing to clarify when designing or redesigning the representative institutions of a modern democracy, especially in a heterogeneous society, should be: How does one see the role of the party system as an intermediary between society and government? Should the party system block the politicization of ethnicity by restricting political competition to ideological and socioeconomic issues? Should it aggregate socio-cultural divisions into broad-based multiethnic or explicitly non-ethnic parties? Or rather, should it translate social cleavages into political faultlines through particularistic parties? In case none of these pure functions is deemed desirable, should a mix of party-system functions be pursued, and, if so, what should the balance be? In other words, choosing a party-system function comes first. The choice of electoral system follows logically from the choice of party-system function. How party-system function relates to electoral-system features is shown in table 2. Electoral systems are listed roughly on the basis of their expected effectiveness, with the electoral system most likely to achieve the designated party-system function at the top of each cell.

The blocking function can be achieved through the one-party state, party bans, and plurality and majority elections (double ballot) in singlemember districts in case of a dispersed minority. Several Western democracies have legislation prohibiting anti-democratic parties (Avnon 1995), but only some new democracies in Eastern Europe ban minority parties (Bogaards 2004a). Dispersed minorities will find it difficult to win seats under plurality elections in single-member districts. Little is known about how two-round majority elections perform in heterogeneous societies, although it would seem to disadvantage dispersed minorities, especially when they cannot agree to electoral alliances with other parties. In France, the double ballot has contributed to the exclusion of extremist parties from parliament (Sartori 1994).

Aggregation can be achieved through a range of electoral systems. The choice of electoral system depends on three factors: the number and relative size of social groups, their geographical distribution or concentration, and the existing party system. The classic idea of a moderate two-party system 
Table 2: The function of party systems and the choice of electoral system

\begin{tabular}{ll}
\hline $\begin{array}{l}\text { Party system } \\
\text { function }\end{array}$ & Appropriate electoral system \\
\hline Blocking & - One-party state \\
& - Party bans \\
& - Majority elections (double ballot) in single-member districts \\
& (in the case of dispersed minorities) \\
& - Plurality elections (in the case of dispersed minorities) \\
\hline Aggregation & - Alternative Vote (AV) \\
& - Constituency pooling \\
& - Distribution requirement \\
& - Single Transferable Vote (STV) \\
& - Prefabricated party system \\
& - Multi-ethnic list voting \\
& - Double-ballot in heterogenous districts \\
& - Communal rolls \\
& - Reserved seats for minorities \\
& - List Proportional Representation (PR) \\
& - Minority parties exempted from electoral threshold \\
& - Plurality and majority elections (in the case of concentrated \\
& minorities) \\
\hline Translation &
\end{tabular}

with broad-based parties that converge toward the centre, stimulated by plurality elections in single-member districts, only holds for homogeneous societies. In heterogeneous societies with communal voting, plurality elections will not produce aggregation. Three types of electoral system will: preferential voting in the form of the alternative vote or the single transferable vote; vote distribution requirements; and constituency pooling. The alternative vote $(\mathrm{AV})$ is a preferential majority voting system with strong incentives for vote pooling given the right circumstances. Vote pooling occurs when political leaders seek support outside their own group to win elections and voters exchange votes across group boundaries. AV asks voters to rank the candidates. If a candidate receives an absolute majority of first preferences, he or she is elected; if not, the weakest candidate is eliminated, and the ballots with that candidate as first preference are redistributed according to the second preferences. This process continues until one of the candidates has collected a majority of the votes and wins the seat. When no party in a district can count on an outright majority, AV necessitates electoral cooperation between the parties: 'to obtain votes across ethnic and racial lines by agreements with other parties to trade second or third or fourth preferences, reciprocal moderation on ethnic or racial issues is required' (Horowitz 1991: 177). Not all parties follow this strategy. Alongside vote pooling 
parties, flank parties will arise. These are 'ethnically based parties surrounding a multi-ethnic coalition and typically espousing ethnically more extreme positions than the coalition, with its mixed support, is able to do' (ibid: 167). Communal voters will tend to cast their first preference for one of these flank parties that appeals to their primary identities but may give their lower preferences to more moderate and inclusive candidates, perhaps even from other socio-cultural groups.

$\mathrm{AV}$ is not widely practised. Australia and Fiji use AV in elections for the main chamber of parliament. Papua New Guinea, a highly diverse society, recently reintroduced AV. Reilly (2001: 94) presents a favourable review of the pre-independence experience with AV in Papua New Guinea, especially when compared to the performance of the first-past-the-post system in use since independence.

AV only leads to vote pooling under two conditions: a multiparty system at the district level and heterogeneous electoral districts. Unfortunately, these conditions are rarely satisfied in Africa. The number of viable candidates in a district is normally low, increasing the likelihood of a candidate winning on the basis of his/her own support group and reducing the need to reach out to other groups. Heterogeneous districts are difficult to draw when groups are geographically concentrated, as is the case in Africa. Mozaffar and Scarritt (1999: 236; see also Scarritt and Mozaffar 1999) note how 'African ethnopolitical groups... exhibit the highest degree of territorial concentration of any region in the world'. This precondition shows the importance of group demographics and political geography for the working of the electoral system.

Constituency pooling is an alternative to $\mathrm{AV}$ as it can achieve vote pooling under a different and less narrow set of conditions (Bogaards 2003). Constituency pooling means that a candidate runs simultaneously in multiple constituencies that are geographically non-contiguous. These districts are selected in such a way that they correspond to societal cleavages. To decide the winner, the total number of votes for a candidate across all districts is calculated. The successful candidate thus has to pool votes from different parts of the country inhabited by different groups. More important than the internal diversity of each district is that the pooled districts taken together are not dominated by any group.

In principle, constituency pooling can be used with any majoritarian formula to decide the winner, but its practice is most easily understood and illustrated in combination with plurality rule. Use of FPTP has one disadvantage: in the case of a fragmented field of candidates, there is less need 
for candidates to reach out to groups other than their own and the necessity to pool votes across constituencies is reduced. That is why constituency pooling is expected to work best with a low number of viable candidates. In sum, constituency pooling promotes vote pooling under conditions that are the opposite of those for AV: a low number of parties instead of a high number of parties; and homogeneous districts versus heterogeneous districts, whereby the requirement of homogeneity is not absolute as what matters is heterogeneity over all the pooled districts. Constituency pooling forces candidates to address issues important to voters across the country and in the long term should dilute the party-political relevance of ethnic identity and promote the rise of national cleavages and issues, something many observers desire from an electoral system (see Tekle 1997: 119). Constituency pooling was invented by President Obote in 1970 in Uganda. A coup prevented constituency pooling from being put into practice and it has since been forgotten, despite its attractive features.

Among PR systems, only the single-transferable vote (STV), practised in Ireland, Malta, and Australia, supports a measure of interethnic vote pooling. For Southern Africa, Reynolds (1999: 121-122) has advocated its adoption. STV is a proportional electoral system practised in small multimember districts with typically between three and eight seats. Voters are required to rank the candidates in order of preference. To be elected, a candidate must win a quota and the larger the number of seats, the lower the quota. This logic is common to all proportional electoral systems. Typical for STV is its preferential voting scheme and the transfer of votes. Superfluous votes for candidates who have already won a seat and votes for the lowest ranked candidates are redistributed until all seats are filled. Under STV, a candidate needs a lower percentage of the vote to be elected than under AV. This reduces the need for candidates to reach out and broaden their appeal. STV is a proportional electoral system and gives only weak incentives for moderation. STV did not produce moderation in Northern Ireland in the 1970s but was more successful in the 1998 elections (Reilly 2001). Because STV works with multimember districts, it is somewhat easier to draw the necessary heterogeneous districts than with AV, preferably practised in single-member districts. Although preferential voting schemes are sometimes criticized for being difficult, the only real difficulty is the counting of the votes, which is done by electoral officials. The actual casting of the vote is only complicated by the need to rank candidates.

A more unusual electoral system that promotes aggregation is a distribution requirement. There are two types of distribution requirement: 
for presidential elections and for parliamentary elections. In Nigeria and Kenya, the successful presidential candidate not only has to win an overall majority or plurality respectively, he/she also has to draw a minimum percentage of votes from a minimum number of regions (see Horowitz 1991; Hartmann 1999). The obvious problem with this type of distribution requirement is the possibility of inconclusive elections. Distribution requirements for parliamentary elections also suffer from this problem, but the experience with this additional decision rule is limited to recent experiments in the Comoros and Nigeria (see below). Distribution requirements can also be imposed on party nominations and party organization. The electoral law may require parties to field lists or candidates in all constituencies in order to take part in seat allocation. The effect of such a distribution requirement depends on the number of constituencies and the conditions for nomination in the form of financial deposits and signatures. Finally, in order to be registered, parties can be compelled to have an organizational presence across the country.

The prefabricated ideological party system will be discussed below. Multi-ethnic list voting requires parties to field religiously (Lebanon) and ethnically (Singapore) mixed lists in multi-member districts. As said above, little study has been done on the effects of the double-ballot for ethnic representation, but in heterogeneous districts the majority system most likely contributes to aggregation when in the second round candidates have to solicit votes from a variety of groups to win.

The party-system function of translation can be ensured through the adoption of reserved seats and communal rolls. Both procedures are contested as they rely on the predetermination of socio-cultural groups and the identification of candidates and/or voters as belonging to designated groups. This implies that separate voter registers must be maintained or candidates need to declare the ethnic group they are standing for. More commonly and less controversially, translation is best served by list proportional representation although it can also be achieved with plurality and majority elections in the case of geographically concentrated minorities. PR facilitates the political organization of small dispersed social groups, which do not have to be geographically concentrated to have a chance of parliamentary representation. The number of relevant parties can be reduced through the adoption of an electoral threshold. Lest the threshold inadvertently bars ethnic minority parties, they can be exempted from it.

If blocking simply aims to keep ethnicity out of politics and aggregation reconciles conflicting interests and values within parties, a party system 
based on the faithful translation of ethnic cleavages into political cleavages does little to accommodate them. The problems are simply projected onto the state's decision-making bodies, where additional arrangements are required in the form of power sharing. Horowitz (1991: 171) warns that '... the mere need to form a coalition will not produce compromise'.

In sum, it is possible to categorize electoral systems on the basis of the party-system functions they promote. However, how a particular electoral system functions in a divided society crucially depends on context. This is well illustrated by the fact that plurality elections can result in blocking or translation depending on the size and geographical distribution of social groups.

\section{Electoral choices in Africa}

What kind of party-system functions have been selected in Sub-Saharan Africa? As can be seen in table 3, African states have made very different choices and have come up with sometimes very innovative electoral systems. ${ }^{1}$ Africa has been a veritable laboratory of mostly indigenous electoral designs for ethnic conflict management. Blocking has been a prominent party-system function, both during the era of the one-party state and after democratization, as reflected in the widespread bans on ethnic, regional, religious or linguistic parties. Aggregation in the form of broad multi-ethnic parties has been the main aim of Nigeria's constitutional engineers since the Second Republic. Translation through a multi-party system reflecting the country's diversity was the explicit goal of the drafters of South Africa's post-apartheid constitution.

\subsection{Blocking}

\section{The one-party state}

After decolonization, 'practically every new African ruler opposed multipartyism on the grounds that the recently created countries were facing an ethnic crisis that would imperil the functioning of the state and the welfare of the political community, a situation that only a single-party supposedly could handle competently and efficiently' (Azevedo 1995: 265). ${ }^{2}$

1. Dates in table refer to elections.

2. For a careful analysis of the politicization of ethnicity in Zambia, see Molteno (1974). 
Table 3: Party-system function and electoral system design in Sub-Sahara Africa

\begin{tabular}{|c|c|c|}
\hline $\begin{array}{l}\text { Party system } \\
\text { function }\end{array}$ & Electoral system & Political system \\
\hline \multirow[t]{2}{*}{ Blocking } & One-party states & $\begin{array}{l}\text { Cameroon 1966-1992 } \\
\text { Ivory Coast 1960-1990 } \\
\text { Kenya 1982-1992 } \\
\text { Mali 1974-1992 } \\
\text { Tanzania } 1965-1995 \\
\text { etc. }\end{array}$ \\
\hline & $\begin{array}{l}\text { Multiparty elections with } \\
\text { ban on particularistic parties }\end{array}$ & $\begin{array}{l}\text { Burundi 1992- } \\
\text { Djibouti 1992- } \\
\text { Ghana 1992- } \\
\text { Kenya 1992- } \\
\text { Mauritania 1992- } \\
\text { Sierra Leone 1996- } \\
\text { Tanzania 1995- } \\
\text { etc. }\end{array}$ \\
\hline \multirow[t]{5}{*}{ Aggregation } & Constituency pooling & Uganda 1970 \\
\hline & $\begin{array}{l}\text { Geographical distri- } \\
\text { bution requirement: } \\
\text { presidential elections }\end{array}$ & $\begin{array}{l}\text { Kenya } 1992- \\
\text { Nigeria } 1979-\end{array}$ \\
\hline & $\begin{array}{l}\text { Geographical distribu- } \\
\text { tion requirement: par- } \\
\text { liamentary elections }\end{array}$ & $\begin{array}{l}\text { Nigeria } 1998 \\
\text { Comoros } 1996\end{array}$ \\
\hline & Prefabricated party system & Nigeria 1987-1993 \\
\hline & Multi-ethnic list voting & Djibouti 1968- \\
\hline \multirow[t]{3}{*}{ Translation } & Reserved minority seats & $\begin{array}{l}\text { Zimbabwe 1980-1985 } \\
\text { Niger 1993- }\end{array}$ \\
\hline & $\begin{array}{l}\text { Compensatory mechanism } \\
\text { to achieve more proportional } \\
\text { community representation }\end{array}$ & Mauritius 1959- \\
\hline & List PR & $\begin{array}{l}\text { Namibia 1989- } \\
\text { South Africa 1994- } \\
\text { Zimbabwe } 1980\end{array}$ \\
\hline
\end{tabular}


The leaders of such countries as Cameroon, Ivory Coast, Kenya, Mali, and Tanzania used 'social pluralism' as an argument against democracy (Ake 1993: 72-73; see also Zolberg 1966). ${ }^{1}$ Nyerere (1967: 196) propagated the idea of 'one-party democracy', asserting that 'where there is one party, and that party is identified with the nation as a whole, the foundations of democracy are firmer than they can ever be where you have two or more parties, each representing only a section of the community'. In 1965, Tanzania organized the first legislative elections in which candidates of the ruling party contested each other (Cliffe 1967; Tordoff 1967). However, the one-party state has only rarely served its avowed purposes. The history of single-party rule in Africa shows that in many countries one group, or coalition of groups, monopolized power (Horowitz 1985). Blocking operated selectively, concentrating power in the ethnic group of the ruling elite and its allies, while shutting out social groups associated with the opposition or losing factions within the ruling party. In fact, because of their proclivity to abuse, one-party states intensified ethnic conflict. For Sierra Leone, Hayward and Kandeh (1987: 47) observe how 'the shift from a multiparty system to a one-party system has seen an intensification of intra-ethnic competition and violence'.

The one-party state can also be viewed as an instrument for aggregation, as the single party was often an alliance of ethnic groups. For example, the PDCI in the Ivory Coast was built 'through co-optation, based on a logic of ethnic coalition-building which recognized that no one group should appear to be dominant' (Crook 1995: 29). Finally, the one-party state has been interpreted as serving the translation of socio-political cleavages through the intraparty representation of social groups. This argument is made most clearly in the consociational analysis of single-parties, like KANU in Kenya (Berg-Schlosser 1985), which also identifies the four principles of consociational democracy (executive grand coalition, proportionality in representation and resource allocation, administrative autonomy for the segments, and a mutual veto to protect core interests) within the single party. However, this analysis mistakes 'hegemonic exchange' (Rothchild 1997) for power-sharing and fails to recognize how the representative monopoly of the single party impairs the translation function (Bogaards 2005).

1. Uganda's no-party system has also been justified with reference to the dangers of multi-party politics. For most purposes, Museveni's 'movement democracy' is akin to a one-party state with elections (Kasfir 1998). 


\section{Party bans}

In a large number of African states parties that seek to mobilize a particular population group are illegal. While democratization is normally equated with the return to multi-party politics, frequently in Africa an explicit exception is made for parties based on clan, community, ethnicity, faith, gender, language, region, race, sect or tribe. As these party bans clearly embrace more than ethnic groups in a narrow sense, we either have to employ a broad notion of 'ethnic party' in which ethnicity refers to any perceptible inherited social characteristic (Jackson 1984) or use the generic term of 'particularistic parties' (Almond and Coleman 1960). A prohibition of particularistic parties, then, serves to block the political organization and representation of socio-cultural differences. Although in some cases party bans serve the interests of the incumbents, as in Kenya, where long-time president Daniel Arap Moi belonged to a minority tribe, party bans are too widespread and too little enforced to be just an instrument in the 'menu of manipulation' in the hands of self-serving elites (see Schedler 2002).

The first ban on particularistic parties in an independent African state was probably adopted by president Nkrumah of Ghana in the 1960s. At present, at least twenty-one African countries have bans on particularistic parties. These are Benin, Burkina Faso, Burundi, Cape Verde, Central African Republic, Democratic Republic of Congo, Djibouti, Equatorial Guinea, Ghana, Guinea, Ivory Coast, Kenya, Liberia, Mauritania, Namibia, Niger, Nigeria, Senegal, Sierra Leone, Tanzania and Togo. Several more have less explicit laws which could conceivably be used to ban particularistic parties (Angola, Cameroon, Chad, Gabon, Madagascar and Mozambique). Particularistic party bans can be classified on the basis of two criteria: the proscribed social basis/cleavage and the relevant facets of party-political organization. Almost any social basis on which parties can organize has been the subject of a ban in Africa. These include brotherhood, clan, community, ethnicity, faith, gender, language, region, race, sect, section, tribe, and even gender, social or economic status, and professional group. The facets of party-political organization that have been targeted are the party programme, its symbols, organization, and membership, either in combination or separately. The Constitution of Sierra Leone from 1991, for example, in article 35(5) denies registration as a political party on the following grounds. First, when 'membership or leadership of the party is restricted to members of any particular tribal or ethnic groups or religious faith'. Second, in the case that 'the name, symbol, colour or motto of the party has exclusive or particular significance or connotation to members of any particular tribal or ethnic 
group or religious faith'. Third, when 'the party is formed for the sole purpose of securing or advancing the interests and welfare of a particular tribal or ethnic group, community, geographical area or religious faith'. Fourth, in the case that 'the party does not have a registered office in each of the Provincial Headquarter towns and the Western Area'.

While party bans in Africa are ubiquitous, examples of banned parties are rare. In Kenya, the Islamic Party of Kenya (IPK) was refused registration, whereupon Islamic politicians decided to run for one of the opposition alliances, FORD-Kenya. In Mauritania, a movement of ex-slaves joined with two other ethnic groupings to form the Parti du Centre Démocratique Mauritien in a deliberate attempt to circumvent the ban on ethnic parties (Pazzanita 1996: 593). One could say that both cases show how easy it is to get around a ban on particularistic parties, but one could also, and more appropriately, conclude that in both cases the ban served its purpose, as politicians were compelled to build or join a broader political platform. In Rwanda, the Mouvement Démocratique Républicain (MDR), a Hutu dominated political party, was banned in April 2003 on the ground of 'divisionisme' (Szajkowski 2005). In Nigeria, in the run-up to the December 2002 elections several political formations appealed against their denial of registration by the Independent Nigerian Electoral Commission (INEC), arguing that a number of requirements in INEC's guidelines for registration were unconstitutional. In the last instance, the Supreme Court agreed. The ruling meant that the INEC can no longer verify the national character of a party's organization and the national scope of its membership, rendering the ban on particularistic parties toothless.

\subsection{Aggregation}

\section{Constituency pooling}

President Milton Obote invented constituency pooling for the 1971 parliamentary elections in Uganda (Bogaards 2003). His proposal for multicandidate elections within the framework of a one-party state envisioned a novel electoral system in which candidates would stand for election in four different electoral districts at the same time: their 'basic' district and three 'national' districts. The country was divided into four regions (North, East, West, and South or Buganda) and each district belonged to a different region. Lots were drawn to link constituencies from the four regions to each other. In each basic district, two to three candidates were allowed to run. The candidate who received the largest overall percentage of votes, 
combining the 'basic' constituency and the 'national' constituencies, would win the seat in the basic constituency. Every voter had four votes: one for a candidate in his basic constituency, plus three for national candidates of his choice. Three months before this novel electoral system would have been put to the test, Idi Amin took power through a military coup, cancelling the elections. The ' $1+3$ ' system, as it became popularly known, was explicitly designed to promote national integration and to curb the direct representation of local interests. Different from Nyerere in neighbouring Tanzania, Obote was not convinced that the one-party state by itself would block the politicization of socio-cultural differences and went to great lengths to devise a novel electoral system to promote national integration through aggregation. The new electoral system forced all candidates for the National Assembly to look beyond their own parochial borders for victory, engaging in what Mazrui (1972: 132) has termed 'electoral polygamy: the idea of marrying each member of parliament to four constituencies, with the concomitant implications which such an arrangement would have in terms of loyalties and obligations'.

\section{Distribution requirements}

Since 1979, a successful Nigerian presidential contender has to win a majority of the vote nationally plus a quarter of the vote in at least two-thirds of the states. A similar arrangement has been used since 1992 in Kenyan presidential elections, where a successful candidate has to win an overall plurality plus 25 percent of the vote in at least five of Kenya's eight provinces. Horowitz (1985: 635-638) presents the distribution requirements in the presidential elections of Nigeria's Second Republic as an example of successful 'vote pooling' and as empirical evidence that constitutional requirements for cross-ethnic campaigns work. Unfortunately, distribution requirements have the disadvantage of potential indecisiveness when no candidate fulfils the requirements. In 1979, such an unfortunate scenario played itself out during the very first elections under the new rules. Shagari of the NPN won convincingly in most of the country, totalling 34 percent of the national vote and securing more than a quarter of the vote in 12 states. In the thirteenth, he stopped just short at 20 percent. This unlikely outcome ignited a fierce debate over the precise meaning of the term 'two-thirds' (Joseph 1981). The Federal Electoral Commission finally resolved the controversy by stating that the 'ordinary meaning' of two-thirds is two-thirds of 25 percent in the $13^{\text {th }}$ state. Had no candidate mustered the required geographical spread of the vote, an electoral college composed of all federal and state leg- 
islators would have chosen the president. Clearly, geographical distribution requirements require a default option. ${ }^{1}$

The Comoros and Nigeria under Abubakar have extended distribution requirements to parliamentary elections. In the Comoros, aggregation was encouraged through a geographical distribution requirement applied to the first parliamentary elections following adoption of the new rules in an October 1996 referendum. The constitutional amendment (article 5) restricted parliamentary representation to parties that won at least two deputies on each of the three islands that make up the island-republic in the legislative elections of December 1996. In case there was only one party that qualified, the runner-up would assume the role of opposition, even if it failed to satisfy the two-deputies-on-three-islands rule. This escape clause was the saving grace for the Front National pour la Justice (FNJ), which won just three seats. Moreover, the rule did not apply to independents.

In Nigeria, general Abubakar applied the distribution requirement to party registration, limiting permanent registration to parties that garnered at least ten per cent of the vote in 24 of 36 states in the December 1998 local government elections. Many politicians from the parties that had registered after the liberalisation of 1998 criticized this rule and INEC later relaxed the threshold to five per cent. Only two parties qualified, the NPN and PDP. The AD was registered under a special clause that relaxed conditions for a third party to five percent of the vote won in more states than the others (Nwosu 2000: 95). Support for the AD is restricted to the Yoruba south-west.

The extension of distribution requirements to parliamentary representation introduces a new threshold of representation, strongly encouraging aggregation. The electoral law of the Comoros is more effective than the solution of Abubakar in Nigeria as it pertains to national elections instead of local elections and is concerned with parliamentary representation rather than party registration. There is no obvious reason parliamentary distribution requirements should be limited to transitional elections. An example of a much less demanding distribution requirement concerning nominations is Benin, where parties are obliged to present lists in each of the country's 18 constituencies. Ghana and Sierra Leone, among others, require parties to have branches throughout the country as a condition for party registration. It is not clear how stringently these requirements are enforced.

1. A problem arises when candidates adapt their strategy more to the default mechanism than the distribution requirement itself when they expect neither they nor their rivals are likely to satisfy these requirements in the first place. 


\section{Prefabricated party system}

The most radical case of party system design is undoubtedly Nigeria's Third Republic. ${ }^{1}$ In 1987 the military regime embarked upon a five-year plan for a return to democracy. A two-party system was written into the Constitution and parties were invited to register, following strict guidelines. However, none qualified and the military government decided to create the two parties itself: the Social Democratic Party (SDP) and the National Republican Convention (NRC). The party programmes and statutes were drafted by the government. The SDP was designed to be a 'little bit to the left' and the NRC 'a little bit to the right' (Akinola 1990). This is because the twoparty system was thought to offer the best chances for democratic legitimacy, political stability and effective government. The restriction to two parties was defended with reference to the classic advantages of the two-party system, such as a clear choice for the electorate, a responsible opposition and a strong government. Also, a two-party system was felt to be best for Nigeria's heterogeneous society. The last point in particular invited criticism. In a bipolar society, a two-party system can be an instrument for the repression of a minority by a majority. Precisely in the Nigerian situation, a two-party system could lead to polarization and the appearance of the North-South cleavage or Christian-Muslim cleavage alongside the ideological (Akinola 1989; Suberu 1990).

The parliamentary elections of July 1992 proved the critics only partly right. Although the SDP found most of its supporters in the south and central regions of the country, while the NRC attracted most of its electorate in the north, 'party alignments showed significant cross-cutting of ethnic and regional cleavages' (Diamond 1995: 453).

The SDP and NRC were indeed national parties, even though they had undeniably regional strongholds. Likewise, in the presidential elections of 1993, 'the vote suggested an historic merger of northern and southern populist interests, superseding the ethnic faultlines which have traditionally structured Nigerian electoral politics' (Lewis 1994: 327). The forceful reshaping of the Nigerian party landscape contributed to the nationalization of voting patterns. Still, nothing in the plurality electoral system for legislative elections could have prevented the prefabricated parties from be-

1. Senegal's 'prefabricated' ideological three-party system (1976-1981), in which parties had to subscribe to one of three official tendencies, Socialist, Liberal or Communist, to be legalized, falls outside the scope of the present discussion as it was not motivated by concern about the politicization of socio-cultural cleavages but a more abstract desire to create a modern, French-style party system. 
ing used by leaders and voters as vehicles for the expression of particularistic interests (see Diamond and Suberu 2002). Despite the success, General Babangida annulled the election results and the country descended again into military dictatorship.

\section{Multi-ethnic list voting}

Like Lebanon, Djibouti uses multi-ethnic list voting in multi-member districts to elect its parliament. By law, party lists have to be composed of members of different groups. In the colonial statute of 1968, the Issas and other Somali people were guaranteed a plurality of 33 seats, the Afars were apportioned 30 seats and the Arab minority received the remaining two seats (Schraeder 1993). This ethnic balance was not achieved through reserved seats or communal rolls, a traditional method of translation, but by mandating inclusive party lists. Since independence in 1977 party lists have to be composed proportionately of candidates from all districts of the country to the same effect. Compulsory multi-ethnic lists have the double function of allowing for ethnic representation through the medium of broad, multi-ethnic political parties. Because Djibouti at the same time prohibits particularistic parties, it would seem that in this case the aggregation function outweighs the translation function.

\section{Double-ballot in heterogeneous districts}

For Mali, Vengroff (1994) observes how the double-ballot in mostly multimember districts 'forces the parties to bring diverse ethnic, familial, and local interests into the party. Since the entire list is elected in each circumscription, and most cercles are ethnically mixed, the result is a relative balance in the distribution of seats between groups'. This outcome resembles the mandatory multi-ethnic list voting found in Djibouti. Apparently, the heterogeneity of Mali's multi-member districts encouraged politicians to field broad lists. The aggregative effect was unintentional, since the double-ballot in Mali was adopted for different reasons, and dependent on local conditions and dynamics. Nonetheless, Mali indicates the potential for aggregation of the double-ballot as long as heterogeneous districts can be carved out.

\subsection{Translation}

\section{Reserved seats}

Communal rolls were common in elections to the consultative assemblies for the indigenous populations under colonialism but they were abolished 
with independence. Exceptionally, communal rolls were introduced in the transitional electoral system for the 1980 and 1985 elections in Zimbabwe. 20 of the 100 parliamentary seats were reserved for Whites, who made up four percent of the population. Only Whites, a category including Asians and Coloureds, could stand as candidates for these seats and only Whites could vote for them. For this purpose, separate electoral registers were set up. Elections took place in 20 one-member FPTP districts whereas PR was used for the rest of the (Black) seats. For all practical purposes then, Blacks and Whites organized their own elections to the same parliament. They even used different electoral systems. The special arrangements were supposed to last seven years. ${ }^{1}$

Special representation rights have been granted to women and traditional leaders in several African states. In Tanzania, for example, 15 percent of seats in parliament are reserved for women. In Botswana traditional leaders form the House of Chiefs while in Sierra Leone 12 parliamentary seats are allocated to Paramount Chiefs, elected according to a plurality system in single-member districts. The legislature of Zimbabwe has a large contingent of indirectly recruited members, including ten Chiefs. Special representation rights for minorities are rare in Africa. Since 1992, successive constitutions in Niger have set apart eight single-member constituencies (out of a total of 83) populated with 'national minorities' in which deputies are determined by simple majority instead of the proportional representation used in regular multi-member districts. In both 1993 and 1999 the minority seats were won by the same parties that led nation-wide (Nohlen et al. 1999: 688; Di Lorenzo and Sborgi 2001). Note that Niger and Sierra Leone prohibit particularistic parties at the same time as they arrange for special parliamentary representation of minority groups and tribal leaders respectively. The paucity of reserved minority seats in comparison to for example Eastern Europe (Bogaards 2004a) can be explained by the preference for the blocking function as well as by the societal composition of African states. In many countries there are only minorities, so how could one privilege one or some over others?

1. Lijphart's (1986: 123) suggestion that the same effect could have been achieved through a different weighting or counting of votes cast for minority parties makes the violation of the democratic principle of one-person, one-vote, one-value even more visible and appears ill-advised. For a discussion of weighted voting in a transitional electoral regime for post-apartheid South Africa, see Burnham (1980). 


\section{Compensation for communal proportionality}

The so-called Best Loser system in Mauritius, a variant of which was already used during the pre-independence elections of 1959, is based on the idea of ethnic proportionality. To correct for the high disproportionality and underrepresentation of the electoral system of plurality in multi-member districts, a maximum of eight seats on top of 62 constituency seats are allocated under the 'Best Loser' formula. For the purpose of the electoral law the population is divided into four main sections: Hindu, Muslim, General Population and Chinese. Candidates have to declare the community they belong to. To determine which community, or party plus community, deserves additional seats, the 'representation quota' of the various communities is compared. The 'representation quota' is derived by dividing the number of persons belonging to that community by the number of seats that the community has obtained in the direct election, plus one. The community with the highest numbers receives an extra representative. Although the Best Loser system is criticized for breeding communalism in times when people 'vote more along party lines rather than along communal lines' (Mathur 1991: 69) it has not been abolished.

\section{PR}

The revolution of 1964 in Zanzibar, in which left-wing Africans overthrew the Arab-dominated government, has been blamed on an electoral system that denied victory to the majority party. Had PR been used, the party's 'strong popular majority would have enabled it to assume power as the result of an orderly electoral process' (Lofchie 1965: 257). Several African countries deliberately adopted proportional representation because of its inclusiveness. At independence, two countries with white settler populations and a history of conflictual race relations opted for PR: Namibia and Zimbabwe. ${ }^{1}$ South Africa deliberately chose proportional representation to obtain an inclusive parliament after apartheid and enshrined proportionality in the constitution. Any reform of the electoral system, such as the introduction of smaller districts to improve accountability, has to maintain overall proportionality (De Ville and Steytler 1996; Mattes and Southall

1. At the same time, the 1992 regulations for registration of voters and political parties in Namibia prohibit parties that restrict their membership on the grounds of sex, race, colour, ethnic origin, religion, creed or social or economic status. In Zimbabwe, PR was used for the common roll only, the seats reserved for 'Whites' were elected by plurality in single-member districts. In 1985, Zimbabwe changed to FPTP for all seats. 
2004). Yet, in the context of geographically concentrated social groups, plurality and majority elections in single-member districts will lead just as easily to the political translation of social differences as does proportional representation. Even a proponent of PR like Reynolds (1999: 210) has to admit that, for example, 'in Namibia the geographic concentration of even the smallest parties rendered the differing incentives of plurality and PR electoral systems negligible'. In Malawi plurality elections have been blamed for fostering a party system with three strong regional parties (Reynolds 1999). However, 'the weight of demographics, regional orientation, and party-president identification in Malawi was such that electoral engineering could not have significantly altered the results' (Posner 1995: 143). In sum, in the case of Africa's geographically concentrated socio-cultural groups translation can be achieved under any of the main types of electoral system: proportional representation as well as plurality and majority elections in single-member districts.

\section{Conclusion}

This brief overview of electoral engineering for ethnic conflict management in Africa has shown impressive creativity on the part of constitutional engineers and demonstrated the usefulness of an alternative classification of electoral systems based on party system function. While the confines of this chapter and the brevity of most experiments do not allow for an in-depth analysis of the consequences of electoral system design, some concluding remarks can be made. The prevalence of bans on particularistic parties in Africa suggests a consensus among the drafters of constitutions, electoral laws, and party regulations, that particularistic parties pose a threat to democracy and social peace. However, while many may share this diagnosis, party bans are not the only or even the best remedy. Enforcement of party bans, especially when their implementation is perceived as selective or self-serving, is likely to fuel rather than quell ethnic conflict. In Eastern Europe, the two countries with bans on minority parties (Albania and Bulgaria) ultimately desisted from enforcing them (Bogaards 2004a). Secondly, the choice for blocking as a party system function is a negative one that will not by itself bring about the desired national integration. Finally, bans on particularistic parties violate one of the nine features of liberal democracy listed by Diamond (1996: 23), namely that 'cultural, ethnic, religious, and other minority groups, as well as traditionally disadvantaged or unempowered majorities, are not prohibited (legally or in practice) 
from expressing their interests in the political process, and from using their language and culture'.

Instead of banning particularistic parties, constitutional and electoral engineers are better advised to design institutions that promote aggregation (Horowitz 1994; Osaghae 1999). If the socio-economic structure of African societies continues to privilege ethnicity as a cleavage for party formation (Erdmann and Weiland 2001), the challenge may be formulated as promoting multi-ethnic parties over parties that represent a single ethnic constituency (see Erdmann 2004). The International IDEA Handbook of Electoral System Design states that 'most experts agree that the system should encourage the development of parties which are based on broad political values and ideologies... rather than narrow ethnic, racial, or regional concerns' (Reynolds and Reilly 1997: 13). To achieve aggregation, specific electoral designs are required. PR is a fair electoral law but by itself does not promote crosscutting cleavages and moderation. STV only gives weak incentives. AV has stronger incentives for vote pooling, but the preconditions for its effectiveness, a district-level multiparty system plus heterogeneous single-member constituencies, are rarely found in Africa. Constituency pooling is a promising alternative, as it works best with a concentrated party system and a multitude of geographically concentrated ethnic groups. These are precisely the conditions one finds in most of Africa (Bogaards 2003). Which electoral arrangement best promotes the party system function of aggregation in a particular country needs always to be assessed in context, because 'any electoral strategy for conflict management needs to be tailored to the realities of political geography' (Reilly and Reynolds 1999: 15). Africa's emerging party systems are shaped by the particular combination of electoral institutions and ethnopolitical cleavages (Mozaffar et al. 2003).

In addition to constituency pooling, there are two other electoral systems invented in Africa that promote aggregation: geographic distribution requirements for presidential and parliamentary elections. Distribution requirements could be used much more widely, provided they are accompanied by a clear and acceptable default option should no candidate or party fulfil the distribution requirements. And not just in Africa. Distribution requirements for presidential elections have been suggested for presidential elections in Bosnia (International Crisis Group 1999) and are used in Indonesia (Horowitz 2003). Constituency pooling has been recommended for the election of the European Parliament (Bogaards 2004b). Unfortunately, some of the most promising electoral systems to come out of Africa are also 
the ones we know least about because they have either never been put into practice (constituency pooling) or have only been used for a single election (parliamentary distribution requirements). However, this should only encourage contemporary African constitutional engineers even more to continue their experimentation, bearing in mind that 'many of the successful electoral systems used in the world today themselves represent innovative approaches to specific problems', as Reynolds and Reilly (1997: 122) write in their advice to electoral system designers. The consensus on the undesirability of particularistic parties displayed in the constitutions of the majority of Africa's new democracies suggests there is a reservoir of political will to promote aggregative party systems through electoral design.

\section{References}

Ake, C. (1993), 'Rethinking African Democracy', in Diamond, L. and M. Plattner, (eds.) The Global Resurgence of Democracy. Baltimore: The Johns Hopkins University Press, pp. 70-82.

Akinola, A. (1989), 'A Critique of Nigeria's Proposed Two-Party System', The Journal of Modern African Studies 27: 1, pp. 109-123.

Akinola, A. (1990), 'Manufacturing the Two-Party System in Nigeria', Journal of Commonwealth \& Comparative Politics 28: 3, pp. 309-327.

Almond, G. and J. Coleman (1960), The Politics of the Developing Areas. Princeton: Princeton University Press.

Avnon, D. (1995), 'Parties Laws in Democratic Systems of Government', The Journal of Legislative Studies 1: 2, pp. 283-300.

Azevedo, M. (1995), 'Ethnicity and Democratization: Cameroon and Gabon', in Glickman, H. (ed.) Ethnic Conflict and Democratization in Africa. Atlanta: African Studies Association Press, pp. 255-288.

Barrows, W. (1976), 'Ethnic Diversity and Political Instability in Black Africa', Comparative Political Studies 9: 2, pp. 139-170.

Basedau, M. (2002), 'Zum Zusammenhang von Wahlsystem, Parteiensystem und Demokratiestabilität in Afrika. Kritische Anmerkungen zum Potenzial von Electoral Engineering', Afrika Spectrum 37: 3, pp. 311-334.

Berg-Schlosser, D. (1985), 'Elements of Consociational Democracy in Kenya', European Journal of Political Research 5: 4, pp. 393-412.

Bienen, H. (1971), 'One-Party Systems in Africa', in Huntington, S. and C. Moore, (eds.) Authoritarian Politics in Modern Society: The Dynamics of Established OneParty Systems. New York: Basic Books, pp. 99-127.

Bogaards, M. (2000), 'Crafting Competitive Party Systems: Electoral Laws and the Opposition in Africa', Democratization 7: 4, pp. 163-190. 
Bogaards, M. (2003), 'Electoral Choices for Divided Societies: Multi-Ethnic Parties and Constituency Pooling in Africa', Commonwealth \& Comparative Politics 41: 3, pp. 59-80.

Bogaards, M. (2004a), 'Electoral Systems and the Management of Ethnic Conflict in the Balkans', in Mungiu-Pippidi, A. and I. Krastev (eds) Nationalism after Communism: Lessons Learned. Budapest: CEU Press, pp. 247-268.

Bogaards, M. (2004b), 'Beyond Proportional Representation: A New Electoral System for the European Parliament', Paper presented at the Second Pan-European Conference on EU Politics, Bologna, 24-26 June 2004.

Bogaards, M. (2005), 'Power Sharing in South Africa: The African National Congress as a Consociational Party?', in Noel, S.J.R. (ed.) From Power Sharing to Democracy: Post-Conflict Institutions in Ethnically Divided Societies. Toronto: McGill-Queens University Press, pp. 164-184.

Burnham, W.D. (1980), 'Milestones on the Road to Democracy: Electoral Regimes and Their Relevance to South Africa', in Rotberg, R. and J. Barratt (eds) Conflict and Compromise in South Africa. Lexington: Lexington Books, pp. 77-105.

Chandra, K. (2005), 'Ethnic Parties and Democratic Stability', Perspectives on Politics 3: 2, pp. 235-252.

Cliffe, L. (ed.) (1967), One Party Democracy: The 1965 Tanzania General Elections, Nairobi: East African Publishing House.

Conteh-Morgan, E. (1997), Democratization in Africa: The Theory and Dynamics of Political Transitions. Westport: Praeger.

Crook, R. (1995), 'Cote d'Ivoire: Multi-Party Democracy and Political Change: Surviving the Crisis', in Wiseman, John (ed.) Democracy and Political Change in Sub-Saharan Africa. London: Routledge, pp. 11-44.

De Nevers, R. (1993), 'Democratization and Ethnic Conflict', in Brown, M.E. (ed.) Ethnic Conflict and International Security. Princeton: Princeton University Press, pp. 61-78.

De Ville, J. and N. Steytler (eds) (1996), Voting in 1999: Choosing an Electoral System. Durban: Butterworths.

Di Lorenzo, A. and E. Sborgi (2001), 'The 1999 Presidential and Legislative Elections in Niger', Electoral Studies 20: 3, pp. 470-476.

Diamond, L. (1995), 'Nigeria: The Uncivic Society and the Descent into Praetorianism', in Diamond, L. et al. (eds.) Politics in Developing Countries: Comparing Experiences with Democracy, 2nd ed. Boulder: Lynne Rienner, pp. 417-491.

Diamond, L. (1996), 'Is the Third Wave Over?', Journal of Democracy 7: 3, pp. 21-37.

Diamond, L. (1997), Prospects for Democracy in Africa. Palo Alto: Hoover Institution on War, Revolution and Peace, Hoover Essays on Public Policy 74.

Diamond, L. and R. Suberu (2002), 'Institutional Design, Ethnic Conflict Management, and Democracy in Nigeria', in Reynolds, A. (ed.) The Architecture of Democracy: Constitutional Design, Conflict Management, and Democracy. Oxford: Oxford University Press, pp. 400-428.

Erdmann, G. (2004) 'Party Research: Western European Bias and the "African Labyrinth", Democratization 11: 3, pp. 63-87. 
Erdmann, G. and H. Weiland, (2001), 'Gesellschaftliche Konfliktlinien, Ethnizität und Parteienformation in Afrika', in Eith, U. and G. Mielke (eds) Gesellschaftliche Konflikte und Parteiensysteme: Länder und Regionalstudien. Wiesbaden: Westdeutscher Verlag, pp. 246-261.

Fish, S. and R. Brooks (2004), 'Does Diversity Hurt Democracy?' Journal of Democracy 15: 1, pp. 154-166.

Hartmann, C. (1999), Ethnizität, Präsidentschaftswablen und Demokratisierung in Afrika. Hamburg: Institut für Afrika-Kunde, IAK-Diskussionsbeiträge 13.

Hartmann, C. (2006), 'The Path of Electoral Reform in Africa', in Basedau et al. (eds) Votes, Money and Violence. Electoral Sysstems and Ethnicity in Africa. Uppsala: Nordiska Afrikainstitutet.

Hayward, F. and J. Kandeh (1987), 'Perspectives on Twenty-Five Years of Elections in Sierra Leone', in Hayward, F. (ed.) Elections in Independent Africa. Boulder: Westview Press, pp. 25-59.

Horowitz, D. (1985), Ethnic Groups in Conflict. Berkeley: University of California Press.

Horowitz, D. (1991), A Democratic South Africa? Constitutional Engineering in a Divided Society. Berkeley: University of California Press.

Horowitz, D. (1994), 'Democracy in Divided Societies', in Diamond, L. and M. Plattner (eds.) Nationalism, Ethnic Conflict, and Democracy. Baltimore: The John Hopkins University Press, pp. 35-55.

Horowitz, D. (2003), 'Electoral Systems: A Primer for Decision-Makers', Journal of Democracy 14: 4, pp. 115-127.

International Crisis Group (1999), Breaking the Mold: Electoral Reform in Bosnia and Herzegovina. Sarajevo. At: http://www.icg.org//library/documents/report_ archive/A400185_04031999.pdf

Jackson, R. (1984), 'Ethnicity', in Sartori, G. (ed.) Social Science Concepts: A Systematic Analysis. Sage: Beverly Hills, pp. 205-233.

Joseph, R. (1981), 'Democratization under Military Tutelage: Consensus and Crisis in the Nigerian 1979 Elections', Comparative Politics 14: 1, pp. 75-100.

Kasfir, N. (1998), “"No-Party Democracy” in Uganda', Journal of Democracy 9: 2, pp. 49-63.

Lewis, P. (1994), 'Endgame in Nigeria? The Politics of a Failed Democratic Transition', African Affairs 93, pp. 323-340.

Lijphart, A. (1977), Democracy in Plural Societies: A Comparative Exploration. New Haven: Yale University Press.

Lijphart, A. (1985), Power-Sharing in South Africa. Berkeley: Institute of International Studies.

Lijphart, A. (1986), 'Proportionality by Non-PR Methods: Ethnic Representation in Belgium, Cyprus, Lebanon, New Zealand, West Germany, and Zimbabwe', in Grofman, B. and A. Lijphart (eds) Electoral Laws and Their Political Consequences. New York: Agathon Press, pp. 113-123.

Lijphart, A. (1999), Patterns of Democracy: Government Forms and Performance in ThirtySix Countries. New Haven: Yale University Press. 
Lijphart, A. (2004), Constitutional Design for Divided Societies, Journal of Democracy 15: 2, pp. 96-109.

Lofchie, M. (1965), Zanzibar: Background to Revolution. Princeton: Princeton University Press.

Mathur, H. (1991), Parliament in Mauritius. Stanley/Rose-Hill: Editions de L'Océan Indien.

Mattes, R. and R. Southall (2004), 'Popular Attitudes toward the South African Electoral System', Democratization 11: 1, pp. 51-76.

Mazrui, A. (1972), Cultural Engineering in Eastern Africa. Evanston: Northwestern University Press.

Molteno, R. (1974), 'Cleavage and Conflict in Zambian Politics: A Study in Sectionalism', in Tordoff, W. (ed.) Politics in Zambia. Manchester: Manchester University Press, pp. 62-106.

Mozaffar, S. and J. Scarritt, (1999), 'Why Territorial Autonomy Is Not a Viable Option for Managing Ethnic Conflict in African Plural Societies', Nationalism \& Ethnic Politics 5: 3-4, pp. 230-253.

Mozaffar, S., J. Scarritt and G. Galaich, (2003), 'Electoral Institutions, Ethnopolitical Cleavages, and Party Systems in Africa's Emerging Democracies', American Political Science Review 97: 3, pp. 379-390.

Nohlen, D. (2000), Wahlrecht und Parteienrecht, 3rd ed. Opladen: Leske and Budrich.

Nohlen, D. et al. (1999) (eds), Elections in Africa: A Data Handbook. Oxford: Oxford University Press.

Norris, P. (2004), Electoral Engineering: Voting Rules and Political Behaviour. Cambridge: Cambridge University Press.

Nyerere, J. (1967), Freedom and Unity. A Selection from Writings and Speeches, 19521965. London: Oxford University Press.

Nwosu, N.I. (2000), 'The Nigerian Local Government Elections of 1998', Commonwealth \& Comparative Politics 38: 1, pp. 93-104.

Osaghae, E. (1999), 'Democracy and National Cohesion in Multiethnic African States: South Africa and Nigeria Compared', Nations and Nationalism 5: 2, pp. 259-280.

Pazzanita, A. (1996), 'The Origins and Evolution of Mauritania's Second Republic', The Journal of Modern African Studies 34: 4, pp. 575-596.

Posner, D. (1995), 'Malawi's New Dawn', Journal of Democracy 6: 1, pp. 131-145.

Reilly, B. (2001), Democracy in Divided Societies: Electoral Engineering for Conflict Management. Cambridge: Cambridge University Press.

Reilly, B. and A. Reynolds, (1999), Electoral Systems and Conflict in Divided Societies, Washington: National Academy Press.

Reynolds, A. (1999), Electoral Systems and Democratization in Southern Africa. Oxford: Oxford University Press.

Reynolds, A. and B. Reilly, (1997), The International IDEA Handbook of Electoral System Design. Stockholm: Institute for Democracy and Electoral Assistance. 
Rothchild, D. (1997), Managing Ethnic Conflict in Africa: Pressures and Incentives for Cooperation. Washington: Brookings Institution Press.

Saideman, S. et al. (2002), 'Democratization, Political Institutions, and Ethnic Conflict: A Pooled Time-Series Analysis, 1985-1998, Comparative Political Studies 35: 1, pp. 103-129.

Sartori, G. (1976), Parties and Party Systems: A Framework for Analysis. Cambridge: Cambridge University Press.

Sartori, G. (1994), Comparative Constitutional Engineering: An Inquiry into Structures, Incentives and Outcomes. New York: New York University Press.

Scarritt, J. and S. Mozaffar, (1999), 'The Specification of Ethnic Cleavages and Ethnopolitical Groups for the Analysis of Democratic Competition in Contemporary Africa', Nationalism and Ethnic Politics 5: 1, pp. 82-117.

Scarritt, J.; et al. (2001), 'The Interaction between Democracy and Ethnopolitical Protest and Rebellion in Africa', Comparative Political Studies 34: 7, pp. 800-827.

Schedler, A. (2002), 'The Menu of Manipulation', Journal of Democracy 13: 2, pp. 36-50.

Schraeder, P. (1993), 'Ethnic Politics in Djibouti: From "Eye of the Hurricane" to "Boiling Cauldron", African Affairs 92, pp. 203-221.

Sisk, T. and A. Reynolds, (eds) (1998), Elections and Conflict Management in Africa. Washington: United States Institute of Peace Press.

Smith, Z.K. (2000), 'The Impact of Political Liberalisation and Democratisation on Ethnic Conflict in Africa: An Empirical Test of Common Assumptions', The Journal of Modern African Studies 38: 1, pp. 21-39.

Suberu, R.T. (1990), 'Federalism and Instability in Nigeria', Plural Societies 19: 2, pp. $145-161$.

Szajkowski, B. (ed.) (2005), Political Parties of the World, 6th edition. London: John Harper.

Tekle, A. (1997), 'Elections and Electoral Systems in Africa: Purposes, Problems, and Prospects', in Elklit, J. (ed.) Electoral Systems for Emerging Democracies: Experiences and Suggestions. Copenhagen: Ministry of Foreign Affairs, pp. 111-121.

Tordoff, W. (1967), 'Tanzania: Democracy and the One-Party State', Government and Opposition 2: 4, pp. 599-614.

Vengroff, R. (1994), 'The Impact of the Electoral System on the Transition to Democracy in Africa: The Case of Mali', Electoral Studies 13: 1, pp. 29-37.

Zolberg, A. (1966), Creating Political Order: The Party-States of West Africa. Chicago: Rand McNally. 


\title{
Political Parties and Violence in Africa Systematic Reflections against Empirical Background
}

\author{
Andreas Mehler
}

This contribution aims at analysing the relationship between political parties and violence in Africa. Violence is not only used as a political instrument by ruthless political entrepreneurs, it can be an established mode of competition. And it depends on a variety of factors: the course and the outcome of the transition, the depth of social cleavages, the quality of the state monopoly of violence, the legitimacy and efficiency of the electoral process and the organisational capacities of the parties themselves. The association of opposition parties with violence is often manipulated by those in power, while repression in the name of the state's monopoly of violence is frequently violence exerted by the party or clique in power. Most of the factors analysed in this contribution are not specific to Africa, but empirical evidence suggests that the frequency of use of violence on the continent might not be mere coincidence. Simplistic arguments highlighting just one of those factors do not reflect reality.

The contribution is subdivided into an introductory section on terminology and approaches, an introductory part on the political history of six countries under scrutiny, and subsequent sections on violence as a political instrument, on violence as a dominant mode of the political struggle and on violence-prone contexts. In the course of the argumentation, several research questions will be raised, which each deserve a profound evaluation by in-depth studies.

\section{Terminology and approaches}

Gero Erdmann (1999: 375) argues for a close link between political science based African studies and international research on political parties. For far too long, the African studies community has ignored mainstream developments in political science. Likewise, findings of the non-OECD world (which might initiate a more general contemplation within the academic field) have been disregarded by mainstream political science in the past. However, only by mutually acknowledging the respective core terminology and explanatory approaches and, simultaneously, respecting empirical 
evidence, is the endeavour of bringing together political science and African studies likely to succeed. Regarding the topic 'parties and political violence', it is necessary to look at the terms 'political entrepreneur', 'neopatrimonialism', 'weak/failed state' (very familiar to the African studies community) and 'cleavages', 'polarisation' and 'anti-system party' (familiar to the mainstream of comparative politics), at least cursorily.

Cleavages denote 'politically effective conflict configurations institutionalised in the social structure' (Eith and Mielke 2001: 11, translation AM). They could be of a different nature in Africa than they are in Europe (see section 4.1). Their existence however is difficult to ignore. Polarisation, defined as 'pattern of inter-party competition' (Bendel and Grotz 2000: 74), in Africa appears to follow from the depth of existing cleavages, and their ramifications for the party system, rather than from 'ideological distance' (Sartori 1976: 135). This understanding permits an explanation for the multitude of so-called 'alliances contre nature' between nominally socialist and conservative parties in Africa, which are obviously built for the sole purpose of gaining or maintaining political power. Maximum polarisation in Africa results from exclusion, that is the polarisation between excluding and excluded parties (see below Côte d'Ivoire, Burundi, Rwanda). Such a polarisation may be supported by an ideology, but it would rarely fit into the traditional left-right scheme.

Formerly well-established terms like anti-system party have been used to describe parties representing (ideologically) extreme positions (in Europe). These parties to some extent had difficulties in distancing themselves from violence as a political means (classic examples are far right and far left parties in the Weimar Republic, and later also in the Federal Republic of Germany). ${ }^{1}$ The term's application to political parties in (Sub-Saharan) Africa however is problematic. The political parties' respective bases of operations differ significantly in Africa and Europe. The different political preconditions existing in 'real' democracies on the one hand and in neopatrimonial hybrid regimes (Erdmann 2002) ${ }^{2}$ - the predominant regime type in Africa

1. Sartori (1976: 133) gives a rather neutral definition: 'a party can be defined as being anti-system whenever it undermines the legitimacy of the regime it opposes' (italics in the original). In this understanding virtually all parties in Sub-Saharan Africa that had been advocating democracy in the early 1990s were anti-system parties, independently of the means employed and of their ideological positions.

2. Erdmann (2002: 329-30) characterizes neopatrimonial hybrid regimes as "a mixture of two, partly interwoven, types of domination that co-exist: namely, patrimonial and legal-rational bureaucratic domination. Under patrimonialism, all power relations between ruler and ruled, political as well as administrative relations, are 
- on the other hand impact on the parties' self-conception, and their opportunities and limits of action. What actually is denoted by 'the system'? In contrast to Europe, the use of force has a specific significance in numerous African political systems. In the case of victorious liberation movements (Mozambique, Zimbabwe, Eritrea etc.) or warlords turning into presidents (Liberia, Chad etc.) 'violence actors' are the ones in power and their continuous ability to mobilise means of violence beyond any constitutional restrictions is an integral part of 'the system'. Thus, the use of force in Africa is not necessarily anti-systemic. Democratic procedures are not (yet?) 'the only game in town'. To put it differently: How would an opposition party behave in conformity with a neopatrimonial system? Probably by being permanently prepared to be co-opted into government. Would it then make sense to term the very few long-time and principled opposition parties in Africa the real anti-system parties? Apparently, the term 'anti-system party' is not very useful in the African context. The term 'anti-ancien régime party' would be more meaningful to denote all those parties that had been opposed to the old single parties during the 'heroic' transition phase. ${ }^{2}$ They can be distinguished from latecomers, opportunists etc.

Parties are generally seen as more state-centred than any other social organisation. What does it mean when the state is weak? How legitimate is the state and its organs, and how illegitimate are violent actions (by par-

personal relations; there is no differentiation between the private and the public realm. However, under neopatrimonialism the distinction between the private and the public, at least formally, exists and is accepted, and public reference can be made to this distinction. Neopatrimonial rule takes place within the framework of, and with the claim to, legal-rational bureaucracy or 'modern' stateness. Formal structures and rules do exist, although in practice, the separation of the private and public sphere is not always observed. In other words, two role systems or logics exist next to each other, the patrimonial of the personal relations, and the legal-rational of the bureaucracy. These spheres are not isolated from each other. Quite on the contrary, they permeate each other: the patrimonial penetrates the legal-rational system and twists its logic, functions, and output, but does not take exclusive control over the legal-rational logic. That is, informal politics invade formal institutions. Informality and formality are intimately linked to each other in various ways and by varying degrees; and this mix becomes institutionalised. Ideally people have a certain degree of choice as to which logic they want to employ to achieve their goals and realise their interests best" (translated by Gero Erdmann).

1. In their category of 'democratisation parties', Erdmann and Weiland (2001: 248) distinguish pro- and anti-parties. After a regime change, this distinction might become blurred, while the original attitude towards dominant or single parties will be recalled at the beginning of a democratic transition.

2. On transition conflicts see Bendel and Grotz 2001: 75. 
ties) against it? With regard to the variety and diversity of African states, the answer will require some degree of differentiation. However, in more and more African states the legitimate monopoly on the use of force has become a mere promise. Even the colonial state was in trouble proving its ability to maintain the monopoly of violence. It delegated authority to 'traditional' leaders who often were or became local despots (Mamdani 1996) - endowed with their own security forces and prisons. The privatisation of violence seems to be proceeding today - so why should political parties not follow the trend? As early in the 1960s, the youth organisations of single parties were often nothing but groups of thugs (see below).

The problem of the term 'political party' needs to be expounded. Is a party itself a political actor or rather the instrument of a few individuals who use it to defend their own interests? The personalisation of political parties in Africa has been highlighted a number of times. The name of a party's chairman or secretary-general is mostly better known than the label of the political organisation represented. And the distance can be small between political entrepreneurs and political-military entrepreneurs (i.e. warlords). In these cases the programmatic substance of political parties tends to be low. However, it should be clear that such phenomena are still exceptions to the rule: African parties do not have to be smoke screens for 'violence actors'.

Finally, the term violence has to be better explained. We may distinguish different dimensions of violence that should not lightly be mixed up. A mass protest demanding political freedoms may escalate into street violence. This is not the same as when a political party decides to go underground and to directly participate in a civil war. All violence is not equal. The following sections will deal with different perspectives on violence: its use as a political instrument, as a mode of competition and as a dependent variable in particular contexts.

\section{Short historical overview of six countries under review}

The following overview is based on empirical data from Francophone Africa, particularly Burundi, Cameroon, Central African Republic (CAR), Chad, Congo (Brazzaville) and Côte d'Ivoire. All these states have had difficulties in fulfilling minimal standards of democratic rule and have experienced more or less widespread violence recently. A brief characterisation of these countries may suffice here.

Burundi has an extremely violent history. First escalations occurred in 1965 when the (Hutu) Prime Minister was murdered. A coup d'état in 1966 abolished the monarchy while the single party UPRONA was main- 
tained. In 1972 a 'selective genocide' on Hutu elites (roughly 200,000 dead) was executed. After a series of coups $(1976,1987)$ and serious interethnic clashes $(1988,1991)$, a multi-party system was re-established leading to the electoral victory of the FRODEBU in 1993 who mobilised mainly Hutu votes. Hutu President Ndadaye's assassination a few months later led to a series of local anti-Tutsi pogroms and a creeping coup (manifest in 1996). The civil war which lasted until 2004 might have caused more than 300,000 deaths. The negotiated transition in 2004 caused considerable hope for a peaceful development.

In Cameroon a single party was established in 1966 following the defeat of the nationalist UPC rebellion (still under French rule, last executions of rebels in 1971). After the resignation of the first President Ahidjo (1982), the current President Biya took over, facing a coup attempt by his predecessor (1984). Under heavy pressure from street protests and after heavy-handed acts of repression Biya eventually accepted a return to multiparty politics in late 1990 . However, he organised massively manipulated elections during the 1990s which led to a widespread public cynicism with regard to democracy 'à la camerounaise'.

In CAR a single party was established in 1962. The Bokassa coup in 1965 was followed by 14 years of sporadic terror. Bokassa was replaced by a French commando action, but multi-party politics lasted only during a two-year period before André Kolingba toppled the president. He created a single party in 1987 and grudgingly accepted multi-party politics only in 1992. Kolingba lost elections to Ange-Félix Patassé in 1993 who immediately engaged in a witch-hunt against the dignitaries of the old regime sidelining the more credible other parties while mismanaging the economy. After mutinies in 1996/97 and a new bloody coup attempt in 2001 Patassé relied on outside support by a Congolese rebel movement and Libya before losing power to his former chief of staff Bozizé who succeeded with Chadian help (March 2003) after more than a year of rebellion. Subsequently, Bozizé did not allow fully fledged democracy.

In Chad all political parties (apart from the ruling party) were dissolved in 1963. Military coups in 1975 and 1979, both linked to the simmering civil war in the north, did not enhance stability. Hissein Habré conquered the capital N'Djaména in 1982 to build up a repressive regime that was violently overthrown by Idriss Déby at the end of 1990. Déby re-established a façade multi-party system and held several dubious elections. Border-zones of the country remained more or less constantly under control of various politicomilitary movements. Chad has a record thick with political assassinations. 
In Congo (Brazzaville) a left-leaning one-party regime reigned from 1964 to 1992, with four successful coups each exchanging the top personnel. A sovereign National Conference in 1991 was supposed to lay the foundation for a multi-party political system . Democracy, however, was shaken from the beginning by several (also including violent) crises in connection with dubious elections. In 1997 President Lissouba was ousted in a coup by former President Sassou Nguesso who was only in 2002 firmly in control of a system which was a democracy only by name.

In Côte d'Ivoire (akin to Cameroon) the political realm was controlled by the PDCI as a single party from 1960 to 1990, when President HouphouëtBoigny opened up with only one serious challenger - the FPI (already operating clandestinely during the 1980s). After the death of the president a serious succession crisis developed. It was won by Henri-Konan Bédié, and his rival Ouattara created a new party (RDR) with regional appeal only. Elections in 1990 and 1995 were grossly manipulated, Bédié developed the ultra-nationalist ideology of Ivoirité which implicitly would harm Ouattara suspected of dubious nationality. At the end of 1999 Bédié was toppled and General Guéi provided a violent interlude before a FPI-led government was established in turmoil in 2000 (see below). A northern rebellion nearly succeeded in toppling the government in September 2002 and a low-intensity civil war followed with a shaky peace agreement negotiated by Paris.

Mali as a 'free' country (Freedom House) has been included here as a 'control case', although its history is no less autocratic. Already at independence Mali was a de facto one-party system. After a successful coup in 1968 a new single party reigned until 1991 when a revolutionary situation led to the military overthrow of the ancien régime. A sovereign national conference laid the foundations for a more or less consensual transition. The ADEMA with its leader Alpha Oumar Konaré became the dominant party in the 1990s (organising acceptable elections with, however, low participation rates) but lost its appeal when its leader left office after his two constitutional terms. Gen. Amadou Toumani Touré, already president during the transition phase, was successful in the 2002 elections. Fostered by a generally consensual style of politics several crises including the northern Touareg rebellion and violently contested elections in 1997 were brought to an end.

\section{Violence as a political means}

Violence is used by actors within political parties for specific purposes. The following section first highlights difficulties in clearly attributing violence to political parties, it proceeds with exploring different motivations for us- 
ing violence. Dominant and ruling parties usually have completely different reasons to engage in violence compared to opposition parties. Major ways of using violence as political means are characterized and exemplified here.

\subsection{The problem of attributing violence to political parties}

Violence often originates from party adherents, but it is not clear whether they act in this capacity. Are political parties the organisational expression of strategic groups capable of conflict management (Schubert and Tetzlaff 1998)? Widner (1997: 70), Schmidt (1997: 280) and Erdmann (1999: 382) discuss how strong political parties are anchored in society. They come to differing results. The most important political parties in nearly all of the countries analysed are associated with ethnic and/or regional interests, and the lion's share of the votes they get comes from the corresponding groups whose interests they represent. This may involve a risk of violence between parties provided that the ethnic or regional groups themselves are engaged in some form of violence. The reference to the phenomenon of so-called 'tribalism' has been used as an argument against the introduction of multiparty systems exactly in this sense for a long time. ${ }^{1}$ However, the reverse logic might prevail: the formalisation of conflicts by turning them into a competition between political parties may be the only option to cultivate non-violent conflict management - if the rules of the game are respected. Therefore the emergence of ethnic parties (and even less ethnic congress parties) is not per se a core problem for preserving peace (Schmidt 1997: 268). In fact, it is the parties' possible disrespect of rules that ultimately creates severe security concerns.

Former single political parties mostly are (and remain) multi-ethnic parties. However, they also tend to exhibit a difficult relationship to violence. While they lose large parts of their patronage power during a typical democratic transition, they often manage to retain the capacity to use violence, particularly if security forces had guarded their interests. A good example is the Rassemblement Démocratique Centrafricain (RDC, see below). Former liberation movements in power are more notorious (e.g. Ethiopia, Eritrea, Zimbabwe) as they are inclined to be reluctant to stand and tolerate the consequences of elections (Schmidt 1997: 269). Other examples include parties founded by former warlords (like the Mouvement Patriotique du Salut/MPS or the Union pour le Renouveau et la Démocratie/URD, both in Chad).

1. See for a critique Erdmann and Weiland 2001: 250f. 
Both the effective use of violence as well as the effective use of peaceful means depend on the parties' capacities to mobilise and organise their followers. Uncontrolled use of violence is an expression of weak organisational capacities. This frequent problem of African parties points again to their unclear nature. Erdmann (1999: 378) stresses that it is for the most part not possible to identify formal adherents of a political party. Members' registers - if they exist at all - prove unreliable, double or triple membership in different political parties is far from exceptional, just as is a subjective feeling of belonging to a party without ever having filled in a membership form. Thus the apparatus of a given political party might not be held responsible for 'spontaneous' escalations of violence perpetrated by sympathisers of a party.

More problems of attribution arise: the personal loyalty towards some particular party leaders may be the most important motivation behind the use of force. In the spectacular case of challenging state authority (and the monopoly of force) in Madagascar after supposedly manipulated elections (February-March 2002), it was a man without a political party, Marc Ravalomanana, who mobilised the masses and thereby challenged the system. He relied on an alliance of associations (Tiako i Madagasikara: TIM). Affiliated organisations of political parties pose another conceptual problem. The violent student organisation Fédération estudiantine et scolaire de Côte d'Ivoire (FESCI) was for a long time associated with the FPI before it split into a pro-FPI and a pro-RDR faction. Both wings were fighting each other. The famous 'young patriots' under Charles Blé Goudé (close to President Gbagbo) - very active since 2002 - are an offspring of one FESCI wing (Konaté 2003). In Mali, the violent student organisation Association des élèves et étudiants du Mali (AEEM) was close at one point to the opposition party Congrès National d'Initiative Démocratique (CNID). Despite these differentiations, there are still examples of direct use of violence by political parties.

\subsection{Violence as an instrument to profit from a 'historical opportunity'}

The tendency to use violence as a means to profit from a 'historical opportunity' can be best exemplified by the behaviour of the long-time opposition parties Front Populaire Ivoirien (FPI) and Rassemblement Démocratique Républicain (RDR) in Côte d'Ivoire. Both parties felt exposed to electoral manipulations by the government in the 1990s. In the run-up to the presidential elections in 1995, they formed an alliance and ultimately decided to boycott the polls. (The so-called active boycott led to some sporadic acts of violence.) When at the end of 1999 a mutiny turned into a coup against the 
ailing Bédié regime, both parties were allegedly involved in the preparations for two distinct coups. ${ }^{1}$ At this stage the violence option had become an instrument at hand. Initially, both parties were represented in the transitional government of rebel general Guéi. The RDR was later kicked out of government and its candidate and leader Ouattara was excluded from running for president on the grounds of some formal rules. Rumours of coup preparations by military officers close to the RDR circulated henceforth.

FPI chairman Gbagbo and Guéi faced each other in the October 2000 elections. In this situation, the FPI leadership worried about once again becoming the victim of outright manipulations. On the day before election day, Gbagbo appealed to his followers to occupy strategic posts in the capital if manipulations took place. On the day after the elections, it soon became clear that Gbagbo, the 'historic opponent', had won. The minister of the interior vainly tried to annul the elections and then to force the independent electoral commission to proclaim false results. The ministry finally announced its own results declaring Guéi the winner in the first round of the presidential elections.

A large popular uprising in Abidjan followed, resulting in the first violent encounters. During the night of 25 October 2000 the headquarters of the presidential guard were attacked unsuccessfully. But on the following day, FPI followers backed by the sympathetic Gendarmerie eventually got the upper hand. The loyalist units fled. The presidential palace was taken over at night and Guéi had to take refuge. While the electoral commission was reassuming the declaration of the results in the different constituencies, a new confrontation unfolded. Violent demonstrations by RDR sympathisers, which had been expected rather in the run-up to the elections, now turned into a contestation of Ggagbo's electoral victory. Bloody encounters between FPI plus Gendarmerie and RDR adherents took place, resulting in downright pogroms against the 'Dioula' (imprecise term used for all 'northerners' suspected of supporting Ouattara). Officially, 171 human beings were slaughtered. Some media accused leading FPI figures of bearing the responsibility for the mass murder. However, it needs to be recalled that it was the

1. Interviews in Abidjan, February 2000. The threat of violence remained: the secretary general of the PPS, a small party supporting Ouattara, said in an interview with Le Patriote (Abidjan, 8 February 2002): '(...) Si dans un pays les dirigeants ne s'engagent pas dans le sens de l'aspiration des populations et pour ce qui concerne le cas de la Côte d'Ivoire, dans le sens de la démocratisation de ce pays, il est évident que ce régime n'est pas à l'abri de révolution populaire ni de coup d'Etat. Le coup d'Etat s'impose par manque de Démocratie.' 
RDR that first opted for violence to get Gbagbo out of office as quickly as possible. These events overshadowed the 'Belgrade type' fall of Guéi.

Seen from the perspective of the RDR and the FPI, the behaviour of both political parties becomes plausible and explicable. Both apparently had seen a 'historical opportunity' to access power - the FPI after 18 years in opposition under repressive conditions, the RDR after seven years of increasing exclusion.

\subsection{Violence as an expression of grievances}

Violence is a common phenomenon in the aftermath of manipulated elections in Africa (on electoral violence see Liisa Laakso in this volume). One telling example is the confrontation after the 1996 municipal elections in Cameroon, when regime-supporting mayors were appointed in the larger cities that had mostly been won by the opposition. Although perfectly legal this was perceived and probably meant as a provocation. In Limbe for example, the municipal council dominated by the opposition party Social Democratic Front (SDF) was passed over as the candidate of the ruling party Cameroon People's Democratic Movement (CPDM), who had been defeated severely at the polls, was named 'delegate of the government' (appointed mayor). There is a lack of information about whether the national executive council of the SDF ordered the upheaval that followed. In any event, the situation became explosive only when security forces were deployed (five dead). The rebellious city was held in a sort of state of emergency for several days.

There are clear indications that the SDF was the real winner of the 1992 presidential elections and only lost due to manipulations ${ }^{1}$, although the list of dirty tricks and irregularities is far too long to allow the reconstruction of precise figures. At any rate, scenes close to civil war developed in the home region of the challenger John Ni Fru Ndi (North West). The leader of a small party close to the regime was assassinated. Once again there are no indications that the party leadership explicitly called upon its sympathisers to use violence. However, Fru Ndi did not have a pacifying effect on the mood of his followers. In his premature 'Victory Speech', he stated: 'Let the Biya regime know that we are ready to fight to the last man to ensure that our victory is not stolen' (Fru Ndi 1992).

European authors usually react negatively if a 'just war' is proclaimed. The revolutionary rhetoric may have lost a lot of its appeal after the end of

1. A former high-ranking minister confirmed to the author (eight years after the elections) that Fru Ndi had won even according to CPDM figures; source: interviews in Yaoundé, August 2000. See Takougang and Krieger (1998: 148-152). 
the Cold War and in the face of the balance sheet of former revolutionaries in power (Angola, Zimbabwe etc.). However, injustice can still turn into violence. There are sufficient comprehensible origins of violent conflicts in Africa. Frequently, they are linked to political, economic or cultural exclusion, the systematic violation of group rights and the biased exertion of force by security forces. Political parties may well become victims of violence or become advocates of victims and in turn, themselves, use violence in their defence. The 'real' motives of a party leadership to behave this way are irrelevant. ${ }^{1}$ The costs of using violence, however, can be substantial, particularly for the party apparatus: exclusion, stigmatisation, and criminalisation.

Mali, seen as a 'showcase' of democracy, had similar experiences in 1997. After 1992 the government party Alliance pour la Démocratie au Mali (ADEMA) quickly developed into a successful patronage party in light of the weakness of the opposition. It managed to dominate the whole political scene. Presidential elections therefore were not only boycotted by the opposition, their leaders also openly called for violence - yet with very limited success. The same happened during the legislative elections in the same year, although the overall regularity of the elections was not in doubt. Radical parties tried to mobilise the unemployed youth in Bamako who perceived themselves as the 'losers of democratisation' (Hanke 2001: 185f).

\subsection{Violence as a means of domination by the state and government parties}

Compared to oppositional hostility, violent behaviour more frequently emanates from ruling parties. This is particularly true for those multi-party systems, which fail to meet minimal democratic standards. Aside from official security forces - who may act on a simple request from local party leaders - party militias or groups of thugs, operating under the umbrella of the party's youth organisation, can be used. One outstanding example of the use of the Cameroonian Gendarmerie for party purposes was the beating up of several opposition leaders in Douala 1991 (Afrika Jahrbuch 1991: 177).

Private militias of high-ranking officials played a big role in the civil war of Congo (Brazzaville): the 'Ninjas' of Lissouba and the 'Cobras' of Sassou

1. Take Côte d'Ivoire as an example: in an atmosphere of increasing exclusion of the Muslim part of the population RDR leader Ouattara, himself formerly a highranking member of the political establishment, succeeded in linking the political expectations and frustrations of his camp entirely with his own political destiny. This contributed to the aggravation of the conflict. The 'boycott actif' of the presidential elections in 1995 and the protests against Ouattara's de-recognition of citizenship in 1999 led to violence. 
Nguessos. Of course both were also leaders of political parties. The same holds true for the former President Patassé in the Central African Republic ('Karako' militia and others). But did party affiliation play a role at all in these cases? The fighters' motivation was probably a mixture of personal loyalty, ethnic allegiance, youth rebellion and material rewards - not loyalty to a party or its ideals. Once again the question of the structural nature of political parties needs to be put on the agenda (see section 2.1).

Violence-prone elements of youth organisations can be found in opposition ranks as well (Abbink/Kessel 2005). But youth organisations of former single parties are probably better organised, particularly of those parties that remained in power after the (re-)introduction of pluralism. An exception might be Côte d'Ivoire where it was not the party youth of the PDCI itself, but so-called 'voyous' (unemployed thugs for hire) who perpetrated acts of violence against the opposition. The youth wing of the CPDM (YCDPM) in Cameroon played a disreputable role in some local conflicts, repeatedly so in the city of Kumba. The son of the local traditional chief who was himself accused of several acts of violence even became the chairman of the YCDPM.

The main aim of acts of violence by party youths is intimidation, usually very effective in the strongholds of the party. Again, a problem of attribution has to be considered. Rivalries between ethnic or clan groups, particularly between 'autochthonous' and 'stranger' communities can be draped in what seems to represent inter-party conflicts. Throughout the year after its formation, the SDF deplored a high number of acts of violence against party members by CPDM militants in the southern part of the country - which happens to be the home region of Cameroon's President Biya (SDF 1991: 7). However, even in the narrative offered by the SDF, the victims were mostly termed 'Non-Beti Cameroonians' or 'Anglo-Bamis' pointing to ethno-linguist identities ${ }^{1}$. After the legislative elections in 1997 the SDF reacted with a dramatic admonition on the grounds of similar experiences, although it never disposed of the corresponding means: 'Groups against whom these armed gangs are used will surely not fold their hands and remain idle in the face of provocation. Those who encourage the activities of these bands had better read the genesis of tribal wars in places like Liberia, Burundi, Rwanda etc. and even the Nigerian Biafra War' (SDF 1997: 3). ${ }^{2}$

1. Actually a disrespectful name, resulting from the contraction of the terms 'Anglophone' and 'Bamiléké'.

2. Fru Ndi's ambiguous statements to the BBC in 1999 with respect to the necessity of an 'armed conflict' were taken as a welcomed plea by the regime that thereupon 
Victims of repression are not necessarily or primarily 'strangers'. At the municipal elections in 1996 in Ebolowa (South Province) the opposition candidate Abel Eyinga, originating from the same region as Biya, claimed that he had received death threats by the CPDM (Socpa 1997: 42). His victory 'could not be', an 'ethnic treason' as was alleged. In both cases the regime combined ethnitisation and violence as its main instruments of domination. ${ }^{1}$

Compared to domestic opponents, ruling parties have considerable advantages on their side: by pointing to the state's supposed monopoly of violence, represented by an elected government, even a biased use of security forces can be justified. Some sort of 'comprehension' can be generated even for the use of party militias against violent demonstrators from the rank of opposition parties. This creates a dilemma for a 'democratic' or non-violent opposition party: either it opts for a radicalisation of strategies with the risk of stigmatisation or it decides to remain loyal to the rules with the result of facing the risk of losing adherents to more radical forces.

\subsection{The particular case of former ruling parties}

Long-standing relations between elites in the party and in the security apparatus are not simply cut off when ruling parties lose elections. In the CAR the former ruling party RDC retained much influence in the security apparatus, particularly in the army during the 1990s. The mutinies in the late 1990s and the attempted violent coup in 2001 evoked more than mere sympathies in the RDC. Ethnic loyalty played a role as well (some comparison to Burundi in 1993 is possible here).

The situation was different for the PDCI in Côte d'Ivoire. The national army was always considered as less important for the security of the regime than the presence of French troops. This meant that there has never been a heavy 'investment' in the national army or the Gendarmerie. Only by nurturing relations of loyalty could former ruling parties hold on to a good chance to use the option of violence or even the option of a violent comeback. This was apparently not in arm's reach for the PDCI.

sent off troops to the North West province (Afrika Jahrbuch 1999: 192).

1. In Burundi, the Jeunesse Révolutionnaire Rwagasore was the militia close to the single party Unité pour le Progrès National (UPRONA) (jointly responsible for the so-called 'selective genocide' in 1972), before it was superseded by more radical Tutsi-youth groups (Sans-échec, Sans-défaite) close to the Parti pour le Redressement National (PARENA) of former president Bagaza in the 1990s - just as the UPRONA was no longer the most radical force against reforms and democratisation. 


\subsection{Provoking violence to raise the costs of authoritarian rule}

An important contribution to the academic debate on transition processes has stressed that one task of the opposition in democratic transitions would be to accelerate the erosion of the ancien régime, for instance by attempting to raise the costs of authoritarian rule (Stepan 1990). Violence and repression generate costs. Symbolic and political costs might be even more important than apparent material costs that accumulate when violence is used by the regime. Media reports on acts of repression may reduce the domestic and international prestige of a government. Cameroon's opposition parties for example were rather successful in denouncing state-sponsored violence in the early 1990s (Mehler 1993: 238).

\subsection{Provoking violence to discredit opposition parties}

Provocation of violence can also work in opposite directions. Governments have - probably more so after September 11 - an interest in discrediting their opposition as violent, thus undemocratic and irresponsible, and, why not, terrorist. Content-related provocations (see the Limbe/Cameroon example) are to be distinguished from manipulations via 'agents provocateurs'. A well-known example happened in Côte d'Ivoire on 18 February 1992 when a demonstration by the FPI degenerated into violence - to the shock of the party's leadership. Notorious thugs were hired - probably by the government - to perpetrate acts of violence. These events led to party leader Gbagbo's conviction and imprisonment.

\subsection{Violence as an instrument for the acquisition of rents by political entrepreneurs}

'Politico-military movements' in Chad are the best examples for this interrelation. The exchanging of political identities from civilian party agent to rebel leader (and back again) is characteristic. The two highest-ranking politicians are 're-civilised' warlords: President Idriss Déby and the Chairman of the National Assembly 'General' Abdelkader Kamougué. The two rebel movements Comité de Sursaut National pour la Paix et la Démocratie CSNPD (under Moise Ketté) and its offspring Forces Armées pour la République Fédérale (FARF) were recognised as political parties (1994, 1998). ${ }^{1}$ Ketté enjoyed ministerial rank before slipping out of the sinecure system and founding a new rebel movement (before he was murdered in 2001).

1. In the second case however only after the murder of FARF coordinator Laokein Bardé; presumably, his own adherents betrayed him. 
This might be called politico-military entrepreneurship in its purest form: blackmailing sinecures with military means. The strategy, however, is dangerous: Mahmout Nahor, whose party, the Union des Forces Démocratiques (UFD) failed to attract many votes at the polls, decided to use violence in 1998. He ordered the kidnapping of tourists from abroad. Their liberation by force cost the lives of 11 people. The UFD was immediately disbanded by court order and, in the logic of revenge, the state reinforced the repression and mistreatment of Nahor's ethnic countrymen in the city of Sarh (Afrika Jahrbuch 1998: 206). The most painful revolt against the Déby regime was designed to be regulated in the same way: to end the war in the Tibesti mountains the former Interior Minister Togoïmi was at a given point (early 2002) ready to accept a peace plan that would have transformed his Mouvement pour la Justice et la Démocratie au Tchad (MDJT) into a political party. The peace process was suspended. Togoïmi was wounded in a landmine explosion before he died in a Libyan hospital. ${ }^{1}$ His soft-line deputy Adoum Togoï immediately tried to negotiate his entry into the sinecure system at the top of a newly formed coalition of smaller movements.

Even though this politico-military strategy could prove risky and immensely costly in terms of human lives it could be very helpful to prove a certain 'nuisance capacity' as the basis to attract 'violence rents' in the form of being incorporated into the government. On the lower rank level, this approach was supplemented by exacting material rewards, in the framework of demobilisation programmes. The bill is usually paid by some donor organisations hoping - oftentimes in vain - to contribute to sustainable peace.

Likewise, the three mutinies (1996-97) in the CAR can be explained by referring to the 'violence rent'. The crisis was temporarily brought to an end after the formation of a coalition government including all political camps and the rebels. Former heads of state and chairmen of political parties Dacko and Kolingba received substantial state pensions - these were awards for disavowing violence after threatening the use of force (Mehler 1999: 208).

\section{Violence as dominant mode of political contests}

The instrumental character of violence was explored in the preceding paragraph but the recurrent use of violence may be a sign for different 'rules

1. The MDJT gained more international attention in March 2004 when its hardline faction captured elements of the Islamist 'Salafist Group for Preaching and Combat' of Ammari Saifi (alias 'Abderrezak al Para') who abducted 32 European tourists in 2003 and were subsequently chased by the armies of Mali and Niger (supported by US intelligence and troops). 
of the game' when it comes to a comparison between established western democracies and recent African experiences with party pluralism. This section distinguishes elements of particular 'modes' of political contest.

The main argument is straightforward: the experiences with systemic violence are frequently older and stronger than those with pluralistic (nonviolent) competition. Violence therefore may be a common mode of political competition in African societies, more common than consensus or co-operation.

At least the examples shown in this contribution attest to this hypothesis. The history of Chad is a history of political assassination (from Outel Bono via Abbas Koti to Laokein Barde); the history of Burundi is full of ethnically heated up violence (1972, 1988, 1991, 1993-2002); in the CAR the political historiography could easily be dominated by the continuities between the excesses of Bokaasa, the murder of former minister Grelombe, and the beating of trade union leaders in 2000. The founding act of the opposition SDF in Cameroon was overshadowed by the shooting of six people by security forces etc. Political parties in Africa act in an extremely violent environment.

It would be wrong to attribute this violence to ethnic confrontation as Western media suggest in their superficial coverage. Horowitz (1985: 344) states that competition in ethnic party systems is a competition only between parties within one ethnic identity group rather than between parties representing different groups - since a transgression of group boundaries is excluded with respect to the definition given. If this definition were right none of our cases - not even Burundi - would fall in this category. Although radical Tutsi claimed that the election of 1993 would have been an ethnic census, it clearly was not: UPRONA proportionately won substantially more votes than the Tutsi component of the population. Election results in the CAR (1993 and 1998/99) show a remarkable similarity concerning the outcome for the ruling party MLPC, which could be explained by the existence of a rather stable ethno-regional alliance of groups (probably ended by the Bozizé revolt and the subsequent armed victory in 2002/03), but there are other notable dynamics, e.g. the declining popularity of the 'fourth' candidate Goumba and other shifting alliances. It looks as if there was indeed no necessity to compete for the votes of ethnic parties' 'core' voters. But violence is not automatically a consequence of a 'sterile' recurrent competition between ethnically identified parties; shifting coalitions and variations in participation rates should be observed more closely. 


\subsection{Electoral violence}

Patrick Quantin (1998: 22) defines electoral violence in Africa as a 'deviant or unconventional form of political participation'. It would accompany electoral processes and not be an obstacle to them. He compares African electoral violence with tumultuous elections in 19th century France in order to illustrate how difficult the consolidation of democracy in deeply divided societies can be. It is evident that the opportunity to make genuine choices is accompanied by more violence - from the 1960s to 1980s there was simply not enough at stake. Quantin (1998: 25) also explains that the pacification of elections depends on their organisation by functioning and accepted institutions. This sheds some light on the failing capacities and legitimacy of electoral administrations in large parts of Africa. Moreover, he argues that actors without any interest in the consolidation of democracy (e.g. longserving presidents who want to save their 'ancien régime') may manipulate excesses of violence to generate arguments against their challengers.

The cases examined in this contribution confirm these hypotheses and deliver examples of Quantin's explanation of electoral violence, e.g. campaigns with (only) some dead in the CAR (1992, 1998 and 1999), scenes close to civil war after the 1992 presidential elections in Cameroon or severe conflicts after the 1993 legislative elections in Congo - the first time when militias close to Kolélas and Sassou Nguesso were fighting each other - with officially 160 dead.

But there is a second form of 'electoral violence': the use of violence to prevent the elections from being held under the existing rules. Violence was used in this manner for example in Mali in 1997 before the rerun of the legislative elections and in Côte d'Ivoire in 1995 as a consequence of the 'boycott actif' before the presidential elections in 1995 ( 25 dead). In these cases, the rules were targeted by violence - which is an indicator of the fact that rules engender a 'cooperative mode' of competition only when they are acceptable to the major 'players'.

\subsection{The absence of a legitimate monopoly of violence}

A legitimate monopoly of violence, the model of European concepts of the state, is rare on the neighbouring continent. Illegitimate monopolies of violence (Rwanda might be an example) rely on repression; the more numerous examples of more or less legitimate oligopolies of violence (Mehler 2003) should lead logically to a high level of violence since all 'violence actors' - be they traditional chiefs, warlords, uncontrolled local representa- 
tives of the central state, religious authorities, but maybe also party leaders (so-called 'big men') in their regional strongholds - will first have to demonstrate their capacities to use violence. Secondly, on the frontiers of their influence zones, we can expect a high risk of violence as these actors compete for followers amongst themselves. Chad may be a good example for both interrelations.

\subsection{Violence as a recurrent mode of political competition}

The historic disaster for the Front pour la Démocratie au Burundi (FRODEBU) was the assassination of the first freely elected Hutu President Melchior Ndadaye and several other leading party representatives by army officers (Tutsi) in October 1993 and the subsequent all too familiar revenge acts. Pogroms against Tutsi in the provinces were attributed to FRODEBU by its rivals and prepared the ground for the coup d'état in 1996, although there are serious doubts that the national leadership was the instigator of the violence (local FRODEBU leaders were undeniably involved). Violence was certainly not an instrument of the party in this case since it contributed to the disruption of the party with the creation of the splinter party Conseil National pour la Défense de la Démocratie (CNDD) and its military wing Force pour la Défense de la Démocratie (FDD) ${ }^{1}$. The FRODEBU leadership insisted on non-violent means and has not yet recovered from still ongoing political assassinations (23 MPs of the party were murdered during the first four years after the elections) and the radicalisation of its followers in the following years. Taken together, all systemic experiences with violence - including political murder and a 'selective genocide' - produce a certain conditioning of the main actors in their attitude towards violence. In Burundi, violence can be seen as the dominant mode of political competition (in comparison to consensus or co-operation); this applies, to a lesser degree, to the other cases.

\section{Conditions favouring or constraining violence}

History alone, and this means the narrative explanation of an 'organic' genesis of specific modes of political competition is helpful heuristically, but analytically not completely satisfactory. This section aims at presenting a systematic while empirically filled picture of important context factors facilitating or impeding violence.

1. Later FDD separated from CNDD. 
Superficial observers would take ethnicity or ethnic polarisation as the main condition favouring violence. This is at best simplistic. Horowitz (1985: 348) argues that ethnic party systems would be inherently unstable: 'As the groups advance mutually exclusive claims to power, so, too, do the parties', a situation that may lead to a coup or civil war. A second look is necessary. First of all, only very few African states offer a picture of rigid ethnic identities. Secondly, it is rather the cleavage-structure that helps to explain why some ethnic contradictions are dangerous. And without the mobilisation strategies of certain leaders they still have a chance to be peacefully managed.

\subsection{Cleavages}

The European party research is heavily influenced by the concept of 'cleavages'. The main cleavages in most European societies were relatively constant over a long period of time and could be labelled centre-periphery, church-state, cities-countryside and capital-labour. African studies scholars have advocated introducing other cleavages to give consideration to the socio-political circumstances on the neighbouring continent (Erdmann and Weiland 2001; Emminghaus 2001). Ethnic polarisation might become an additional cleavage or the main expression of the centre-periphery cleavage (Schmidt 1997: 268; Erdmann and Weiland 2001: 246; Mozaffar et al. 2003). Interestingly and largely comprehensibly, Menthong (1998: 42) characterises the Cameroonian parties as follows: 'les partis politiques reproduisent en grande partie les clivages ethniques' (to a large extent the political parties reproduce the ethnic cleavages). However, in the case of Mali this would not be accepted so easily. Some differentiation is necessary and, additionally, some caution is appropriate. In Cameroon, as Menthong writes herself, the stigmatisation of opposition parties as representatives of 'rebellious regions and ethnic groups' has a certain tradition (Menthong 1998: 16) and we should not easily fall prey to ideology.

However, perceptions and history matter. The 'historic' opposition party Union des Populations du Cameroun (UPC) was already banned and persecuted without mercy under the French mandate in the late 1950s. The party had a strong backing (for different reasons) from the Bassa (coast) and the Bamiléké (west). Particularly the Bamiléké were excluded from different spheres of public life in the decades to come. In the 1960s the UPC became an 'illegal revolutionary party dedicated to the violent overthrow of the regime' (Foltz 1973: 156). This type of opposition party has virtually disappeared from the African scene today. The UPC has changed as 
well. After the military defeat, splits in exile, the end of the Cold War and new disruptions in the 1990s the appeal of the party has declined strongly. What remained was the 'Bamiléké problem'. And the 'Anglophone problem' added to it - the difficult relationship between the Anglophone minority (roughly one fifth of the population) and the majority living in the Francophone part of the country. The SDF was 'born' in the Anglophone part, but soon found support from both groups, that is it used both cleavages to secure itself a solid place in the 'conflict arena.'

The parallel configuration of cleavages in Côte d'Ivoire (north-south, Christian-Muslim) was present in a latent fashion during the 1990s. At the end of 2000 public statements of religious opinion leaders pointed to a more and more explicit linkage. ${ }^{2}$ On a national level we are witnessing coalitions of ethnic groups at work to form these big blocs. In a way the ethnic cleavage has been overcome, and this is quite similar to the situation in Congo, CAR or Chad. However, this constellation is not less violentprone. What makes cleavages dangerous is their parallel constitution. If ethnic, religious, regional and/or linguistic frontiers are more or less identical existing cleavages may reinforce each other.

\subsection{Outcome of the transition process}

The few examples given in this contribution may suffice to show how little progress in democratisation can be achieved by the mere introduction of a multi-party system. The concrete events of violence may also be linked to the path of the transition process (Van de Walle and Buttler 2000: 42). However, four main types may be distinguished.

\section{Type A: The transition has not yet taken place before widespread violence occurred}

This type might be exemplified by three cases. 1. In Cameroon the ruling party has constantly been in power since independence; the 'ancien régime' has survived the hottest contestation phases i.a. by manipulating elections. 2. In Chad President Déby seized power in 1990 by military means, promised democracy, but conceded only a sterile form of party pluralism. Fi-

1. However, the SDF lost substantial ground in the Bamiléké region in the 2002 parliamentary elections and may have lost this position.

2. See the remarks made by the spokesperson of Imams, Aboubacar Fofana, to Afrique Express, 15 November 2000. 
nally, the first major outburst of violence in Côte d'Ivoire was the climax of the transition process. ${ }^{1}$

\section{Type B: The transition was perverted by a coup}

Burundi is one example of this type. Democratisation was on its way when a few months after model elections in summer 1993 and the subsequent handing over of power the President was brutally murdered. A creeping coup transformed into a manifest one in 1996, the army retook power, while a bloody civil continued.

\section{Type C: The transition was perverted by undemocratic behaviour of democratically elected rulers.}

The winner of the elections in Congo, Lissouba, bears a good part of the responsibility for the abortion of the democratisation process and the ensuing civil war (1997-99) by having militarily attacked the residence of his predecessor (on 5 June 1997). Nevertheless, there are speculations that Sassou Nguesso had prepared for a coup himself. Escalations of violence, however, as early as in 1993/94 originated in Lissouba's camp. The CAR stands for a slightly less dramatic variant of this scenario. President Patassés's governance style has included widespread mismanagement, self-enrichment, the buying-over of MPs and the exclusion of formerly privileged groups. These factors formed the background for mutinies, coup attempts and the final successful rebellion. However, in both cases the former single parties did not play in accordance with the rules of democracy either.

\section{Type D: The transition succeeds}

Mali is the only case observed here where the transition process has succeeded - despite, however, some structural weaknesses. The violent episodes surrounding the elections of 1997 instigated by weak opposition parties could not jeopardise the institutions. With the election of 'ATT' a peaceful change of the governing party was managed.

The case for observing transition courses and outcomes is rather simple. 1) In the absence of a level playing field at elections violence becomes more likely. The experiences of Cameroon, Chad and Côte d'Ivoire in the 1990s attest to this. 2) If a historical change is reversed with violent means in only a few months time - like in Burundi - this is a safe recipe for disaster (or

1. The democracy standard in Côte d'Ivoire in 2001 was certainly much higher than before - despite the political turmoil. After the combined attempted coup and rebellion on 19 September 2002 the democratic standard (as well as the overall stability) has declined again dramatically. 
civil war, for that matter). 3) And if correctly elected politicians do not differ from their autocratic predecessors - as in Congo-Brazzaville and in the $\mathrm{CAR}$ - and in addition openly persecute the followers of their predecessors, this is a clear invitation to an attempted coup by the formerly privileged groups.

\subsection{Institutional conditions: Constitution and electoral laws}

The interrelation between election results, which follow from the functional logic of an electoral system, and violence is significant. Electoral systems can have an important impact on the composition of parliaments. ${ }^{1}$ They can either have an 'including' or an 'excluding effect'. In particular, majority vote systems in single-member constituencies can have problematic effects (Säve-Söderbergh and Lennartsson 2002: 367). ${ }^{2}$ In Burundi, the combination of proportional representation in small constituencies combined with a 5 per cent threshold led to a predictable win of mandates only for the main parties FRODEBU and UPRONA. The election result contributed to the already perceptible polarisation. With 71 per cent of the votes FRODEBU won four-fifths of the seats in parliament, the sufficient margin to change the Constitution where minority rights were guaranteed (Mehler 1994; 1995). An ill-adapted Constitution and electoral laws favouring grossly disproportional results can be important conflict-aggravating factors (although not more than that). ${ }^{3}$

\subsection{State weakness}

All the states analysed in this contribution can be called 'weak'. The relationship between political actors and the propensity to use violence can be expected to depend on the enforcement of a state monopoly of violence

1. Van de Walle (2003: 301) stresses that the performance of a specific party in the first legislative and particularly the first presidential election is critical to its longterm fortunes. This makes the initial 'rules of the game' particularly important. See as well the discussion of relationships between institutions, ethnopolitical cleavages and party systems in Mozaffar et al. (2004).

2. Although this depends on particular contexts: Nohlen, et al., 1999: 24f. A textbook case is the 1993 general election in Lesotho, when the Basutoland Congress Party gained 75 per cent of the votes, but 100 per cent of the mandates. This proved extremely conflict-prone when important veto-players (the crown and the military) did not support the BCP.

3. The effects of the 'institutional fine mechanics' of presidential elections are analysed in Hartmann 1999. 
and/or its empirical legitimacy. The erosion of the state monopoly of violence in Côte d'Ivoire had been visible long before the crises in 1999/2000 and 2002. Phenomena such as the multiplication of self-defence committees even in the metropolis of Abidjan and the growing attraction of 'traditional' institutions like the 'Dozos' ('traditional hunters', originally a secret society of the Senoufo in the north of the country, Förster 2004: 22ff; Bassett 2004) endorse this hypothesis. ${ }^{1}$ Significantly, the Ouattara family could claim absolute power in its stronghold of Kong in the turmoil of 2000 - after the government's representatives had fled.

Leaders and adherents of opposition parties can temporarily control the use of violence in other cases as well ${ }^{2}$ - and these 'oligopolies of violence' are possibly more acceptable to citizens than the misapplication by state officials. One particular form of post-colonial 'indirect rule' beyond the state monopoly of violence may work in close connection to the party membership of traditional authorities. The Lamido of Rey Bouba (north of Cameroon, member of the Central Committee of the CPDM) has his own army and his own prisons. In the campaign for the 1996 municipal elections 40 activists of the opposition party UNDP were attacked by armed followers of the Lamido, one UNDP MP died. One year later seven people were killed in a comparable event, another MP of UNDP was detained and forced to stay in prison for three years (Afrika Jahrbuch 1996: 195; 1997: 190).

Who profits from state decay? Against all plausibility this could be the ruling elite itself. The growing informalisation of nearly every aspect of public life - experienced in Cameroon for some twelve years now - can be profitable to the powerful since they are able to care for their interests even in situations of near-anomy.

\subsection{Neopatrimonialism and violence}

Finally, one of the main conditions of the use of violence in our cases is the principal form of domination usually referred to as neopatrimonialism. Cameroon and Côte d'Ivoire in the 1970s were seen as models for this system: no division between the private and the public sphere, dominance of clientelism over formal procedures, but existence of rational-legal facades,

1. The RDR used Dozos for its own 'security service'; see Kipré 2002: 111, Bassett 2004: 40. Bassett (2004: 39) reminds us that other parties, particularly the PDCI, used them as well during the 1990s.

2. After the electoral defeat of CPDM, a de facto alliance of traditional leaders with the SDF in parts of the north west province in Cameroon developed lists including some prominent chiefs in municipal elections in 1996. See Jua 2003: 7-8. 
which could well function in selective areas - last but not least in the repression apparatus. Elite accommodation was a function of the distribution of sinecures. The well-embedded economic deficiencies, the dynamics of the education system (multiplication of elite aspirants) and unfavourable world market conditions for major export commodities moved both regimes close to implosion. The incapacity to maintain the logic of distribution led to conflicts - and partly violent ones. Neopatrimonialism has proved structurally unstable. However, less perfect systems listed in other cases were not less exposed to violence. The experience with the dominant system may have delayed violent reactions in Côte d'Ivoire and Cameroon: after all you may be co-opted into the system even if you have to wait. Thus the relationship between neopatrimonialism and violence may still be ambivalent.

A synopsis of these reflections is displayed in the table at the end of this chapter.

\section{Conclusion}

The use of violence by political parties depends on a variety of factors: the course and the outcome of the transition, the depth of social cleavages, the quality of the state monopoly of violence, the legitimacy and efficiency of the electoral process and the organisational capacities of the parties themselves. Within the general framework of these conditions party leaders have some room to manoeuvre to use violence as a political instrument in different ways. Ruling parties usually have more options at hand. Violence may be used (in the short term) as an instrument by opposition parties to profit from a historic chance to accede to power. In the medium term, it may be part of a strategy to raise the cost of the authoritarian rule of the government. Sporadically, it may be used to express grievances. Additionally, there is a possibility to use violence to blackmail rents. These factors are probably not specific to Africa, but empirical evidence suggests that the frequency of use of violence might not be a coincidence. The quality of the democratic process, however, has remained poor: cleavages are still in the process of deepening in the course of violent conflicts, states continue to disintegrate etc. These factors may explain why political parties are frequently associated with violence in Africa, although they should not serve as an excuse. However, some recurrent assessments of violence by opposition parties deserve modification: violence is not a sign of 'premature democracy'. Additionally, 'state' violence in the name of the monopoly of violence is often not more than partisan violence of the party or clique in power. And rewarding the 
use of violence by admitting the perpetrators to the negotiation table after a show of force is very dangerous (Tull and Mehler 2005). This could prompt peaceful movements to change their strategy.

A whole list of open questions remains. One of the research gaps concerns in-depth interviews with party leaders and adherents focusing on questions of empirical legitimacy of violent and non-violent behaviour. Biographic studies on careers of violent party members/youth should offer more insights on individual motivations (and consequences) of the violence option: Did it foster, hamper or imprint the political career? And finally, a more systematic combination of electoral studies and research on political parties in Africa promises to deliver insights for both areas of interest. Taken individually, both areas remain at best rudimentary.

\section{References:}

Abbink, J. and I.v.Kessel (eds) (2005), Vanguard or Vandals. Youth, Politics and Conflict in Africa. Leiden: Brill.

Bassett, T.J. (2004), 'Containing the Donzow: The Politics of Scale in Côte d'Ivoire', Africa Today 50: 4, pp. 31-49.

Beyme, K. v. (2000), Parteien im Wandel. Von den Volksparteien zu den professionalisierten Wählerparteien. Wiesbaden: Westdeutscher Verlag.

Bendel, P. and F. Grotz (2000), 'Parteisysteme und Demokratisierung. Junge Demokratien in Afrika, Asien und Lateinamerika im Vergleich', Nord-Süd Aktuell 1, pp. 70-80.

Berdal, M. and D. Malone (Eds) (2000), 'Greed and Grievance. Economic Agendas in Civil Wars'. Boulder: Lynne Rienner.

Collier, P. and A. Hoeffler (2000), Greed and Grievance in Civil War, CSAE Working Paper 18. Oxford: Center for the Study of African Economies, Oxford University.

Diabacté, A. (1997), 'Les conflits électoraux, origines, types et manifestations', Démocraties Africaines 12, pp. 55-60.

Eith, U. and G. Mielke (2001), 'Einleitung', in Eith, U. and G. Mielke (eds) Gesellschaftliche Konflikte und Parteiensysteme. Wiesbaden: Westdeutscher Verlag, pp. 11-15.

Emminghaus, C. (2001), 'Politische Parteien in Botswana und Namibia. Volatitilität und Cleavagestruktur im Konsolidierungsprozess', draft. Hamburg: Institut für Afrikakunde.

Erdmann, G. (1999), 'Parteien in Afrika. Versuch eines Neuanfangs in der Parteienforschung', Afrika Spectrum 34: 3, pp. 375-393.

Erdmann, G. (2002), 'Neopatrimoniale Herrschaft - oder: Warum es in Afrika so viele Hybridregime gibt', in Bendel, P., Croissant, A. and Rüb, F. (eds) 
Zwischen Demokratie und Diktatur. Zur Konzeption und Empirie demokratischer Grauzonen. Opladen: Leske und Budrich, pp. 323-342.

Erdmann, G. and H. Weiland, (2001), 'Gesellschaftliche Konfliktlinien, Ethnizität und Parteiformation in Afrika', in Eith, U. and G. Mielke (eds) Gesellschaftliche Konflikte und Parteiensysteme. Wiesbaden: Westdeutscher Verlag, pp. 246-262.

Foltz, W. (1973), 'Political Opposition in Single-Party States of Tropical Africa', in Dahl, R.A. (ed.) Regimes and Opposition. New Haven and London: Yale University Press, pp. 143-170.

Förster, T. (2004), 'Am Rande des Staates. Der Norden der Côte d'Ivoire 1979-2002', in Beck, K. et al. (eds) Blick nach vorn. Festgabe für Gerd Spittler zum 65. Geburtstag. Köln: Rüdiger Köppe Verlag, pp. 14-27.

Fru Ndi, J. (1992), 'Victory Speech by Ni John Fru Ndi', Bamenda (21 October 1992), hekt.

Hanke, S. (2001) Systemwechsel in Malil: Bedingungen und Perspektiven der Demokratisierung eines neo-patrimonialen systems. Hamburg: Institut für Afrikakunde.

Hansen, K.F. (2003), 'The Politics of Personal Relation: Beyond Neopatrimonial Practices in Northern Cameroon', Africa 73: 2, pp. 202-225.

Hartmann, C. (1999), Ethnizität, Präsidentschaftswahlen und Demokratisierung in Afrika (=Fokus Afrika. IAK-Diskussionsbeiträge; 13). Hamburg: Institut für Afrikanunde.

Horowitz, D.L. (1985), Ethnic Groups in Conflict. Berkeley: University of California Press.

Institut für Afrikakunde (1991-2002) (ed.) Africa Jahrbuch. Opladen: Leske und Budrich.

Jua, N. (2003), 'The State, Traditional Rulers and "Another Democracy" in PostColonial Cameroon', Africa Insight 32: 4, pp. 3-11.

Kipré, P. (2002), 'Le discours politique de décembre 1999 à l'élection présidentielle d'octobre 2000: thèmes, enjeux et confrontations', in Le Pape, M. and C. Vidal (eds) Côte d'Ivoire. L'année terrible 1999-2000. Paris: Les Editions Karthala, pp. $81-121$.

Konaté, Y. (2003), 'Les enfants de la balle. De la FESCI aux mouvements de patriotes', Politique Africaine 89, pp. 49-70.

Mamdani, M. (1996), Citizen and Subject. Contemporary Africa and the Legacy of Late Colonialism. Princeton: Princeton University Press.

Mehler, A. (1993), Kamerun in der Ära Biya. Bedingungen, erste Schritte und Blockaden einer demokratischen Transition. Hamburg: Institut für Afrikakunde.

Mehler, A. (1994), 'Burundi: Das Scheitern einer Demokratisierung von oben', Afrika Jahrbuch 1993. Opladen: Leske und Budrich, pp. 24-34.

Mehler, A. (1995), “'Gründungswahlen” und "Fassadenwahlen”. Plädoyer und Skizze für eine künftige Wahlforschung in Afrika südlich der Sahara’ (= Focus Afrika. IAK-Diskussionsbeiträge; 12). Hamburg: Leske und Budrich. 
Mehler, A. (1999), 'Meuterei der Armee und Tribalisierung von Politik in der "demokratisierten Neokolonie" Zentralafrikanische Republik (ZAR)', in Zinecker, H. (eds.) Unvollendete Demokratisierung in Nichtmarktökonomien. Die Blackbox zwischen Staat und Wirtschaft in den Transitionsländern des Südens und Ostens. Amsterdam: G-und-B-Verlag Fakultas, pp. 193-211.

Mehler, A. (2003), Legitime Gewaltoligopole in Westafrika - eine Antwort auf strukturelle Instabilität? Hamburg: Institut für Afrikakunde.

Menthong, H.-L. (1998), 'Vote et communautarisme au Cameroun ,un vote de cœur, de sang et de raison', Politique Africaine 69, pp. 40-52.

Mozaffar, S., J.R. Scarritt and G. Galaich (2003), 'Electoral institutions, ethnopolitical cleavages, and party systems in Africa's emerging democracies, American Political Science Review 97: 2, pp. 379-390.

Nohlen, D. et al. (eds.) (1999), Elections in Africa. A Data Handbook. Oxford: Oxford University Press.

Quantin, P. (1998), 'Pour une analyse comparative des élections africaines', Politique Africaine 69, pp. 13-26.

Säve-Söderbergh, B. and I.N. Lennartsson, (2002), 'Electoral Assistance and Democratization', in Hampson, F.O. and D. Malone (eds) From Reaction to Conflict Prevention. Opportunities for the UN system. Boulder: Lynne Rienner, pp. 357-377.

Sartori, G. (1976), Parties and Party Systems. Cambridge: Cambridge University Press.

Schmidt, S. (1997), 'Parteien und demokratische Konsolidierung in Afrika unter besonderer Berücksichtigung der Entwicklung Kenias', in Merkel, W. and Sandschneider, E. (eds) Systemwechsel 3. Parteien im Transformationsprozess. Opladen: Leske und Budrich, pp. 251-292.

Schubert, G. and R. Tetzlaff (eds) (1998), Blockierte Demokratien in der Dritten Welt. Opladen: Leske und Budrich.

Social Democratic Front (SDF) (1991), Press Statement delivered by SDF, Yaoundé (16 June 1991), hekt.

Social Democratic Front (SDF) (1997), Press Conference of the National Chairman of the SDF, Yaoundé (16 June 1997), hekt.

Socpa, A. (1997), 'Impact social, politique et humanitaire des conflits ethniques au Cameroun', Démocraties Africaines 12, pp. 38-47.

Stepan, J. (1990), 'On the tasks of a democratic opposition', Journal of Democracy 1: 2, pp. 41-49.

Takougang, J. and M. Krieger (1998), African State and Society in the 1990s. Cameroon's Political Crossroads. Boulder: Lynne Rienner.

Tetzlaff, R. (2000), 'Vierzig Jahre politische Herrschaft in Afrika: Vom postkolonialen Einparteistaat zu Mehrparteindemokratie oder raubwirtschaftlicher Kriegsherrschaft', Nord-Süd aktuell 4, pp. 709-724.

Tull, D. and A. Mehler (2005), 'The hidden costs of power-sharing: Reproducing insurgent violence in Africa', African Affairs 104: 416, pp. 375-398.

Van de Walle, N. (2003), 'Presidentialism and clientelism in Africa's emerging party systems', Journal of Modern African Studies 41: 2, pp. 297-321. 
Van de Walle, and K.S. Butler (2000), 'Partis politiques et systèmes de partis dans les démocraties "non libérales" africaines', Afrique Politique, pp. 41-57.

Widner, J. (1997), 'Political parties and civil societies in sub-Saharan Africa', in Ottaway, M. (ed.) Democracy in Africa. The hard road ahead. Boulder: Lynne Rienner, pp. 65-82.

Ziemer, K. (1978), Politische Parteien im frankophonen Afrika. Meisenheim: Anton Hein Verlag. 


\begin{tabular}{|c|c|c|c|c|c|c|c|c|c|}
\hline$\dot{\bar{\jmath}}$ & (3) & 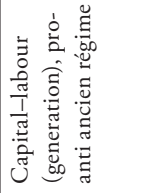 & 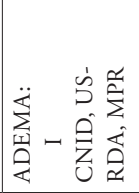 & 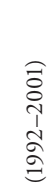 & 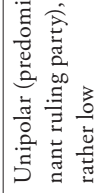 & 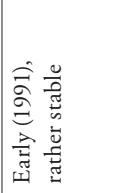 & 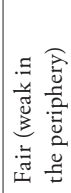 & 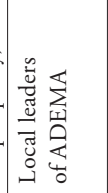 & 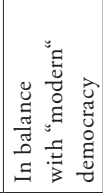 \\
\hline$\stackrel{\pi}{3}$ & $\begin{array}{l}\frac{c}{.000} \\
\overline{\mid c}\end{array}$ & 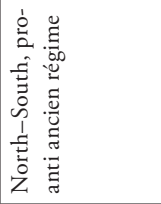 & 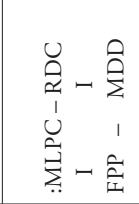 & 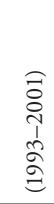 & 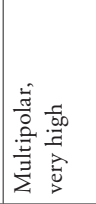 & 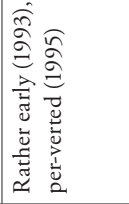 & 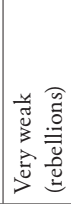 & 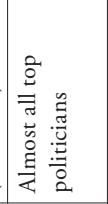 & 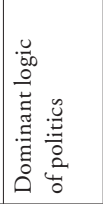 \\
\hline $\begin{array}{l}\mathbb{Z} \\
\text { U }\end{array}$ & 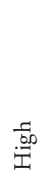 & 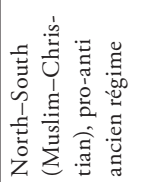 & 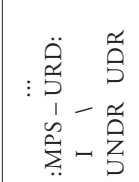 & 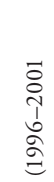 & 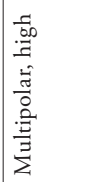 & 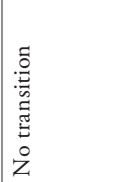 & 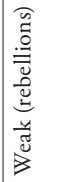 & 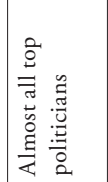 & 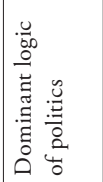 \\
\hline 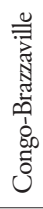 & 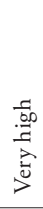 & 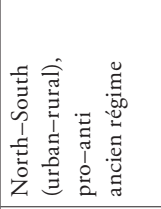 & 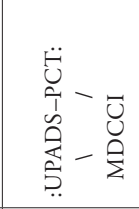 & $\begin{array}{l}\widehat{\infty} \\
\stackrel{1}{\Lambda} \\
\check{\sigma} \\
ٍ\end{array}$ & 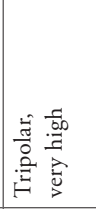 & 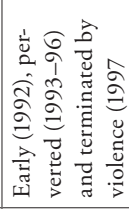 & 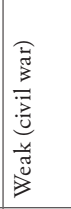 & 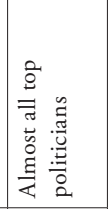 & 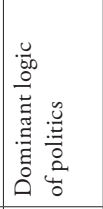 \\
\hline 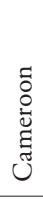 & $\frac{\frac{5}{60}}{\frac{.00}{2}}$ & 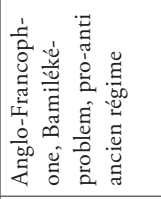 & 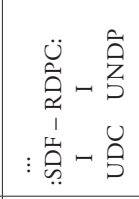 & 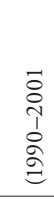 & 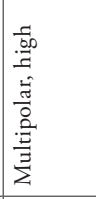 & 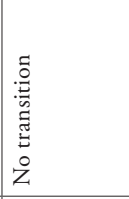 & 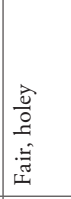 & 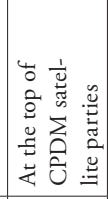 & 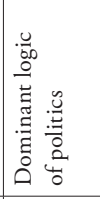 \\
\hline 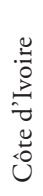 & $\begin{array}{l}\frac{1}{.00} \\
\frac{.00}{2} \\
\frac{2}{2} \\
>\end{array}$ & 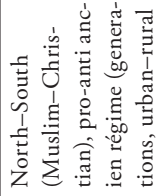 & 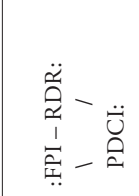 & 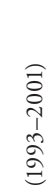 & 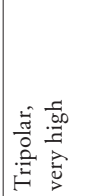 & 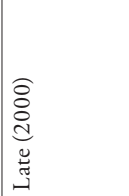 & 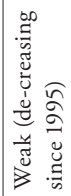 & 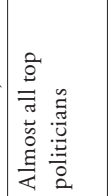 & 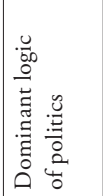 \\
\hline 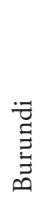 & 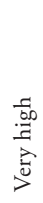 & 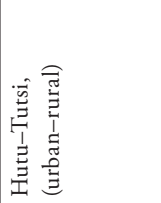 & $:$ : & 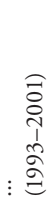 & 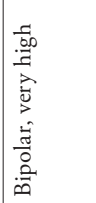 & 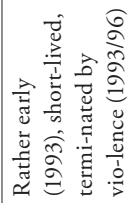 & 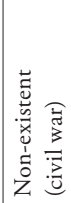 & 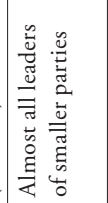 & 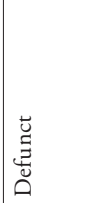 \\
\hline & 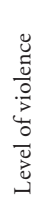 & 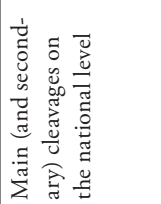 & 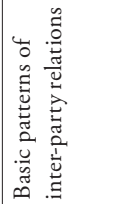 & & 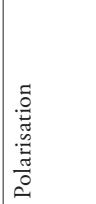 & 莺 & 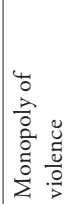 & 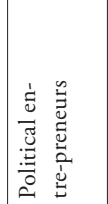 & 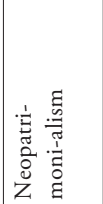 \\
\hline
\end{tabular}



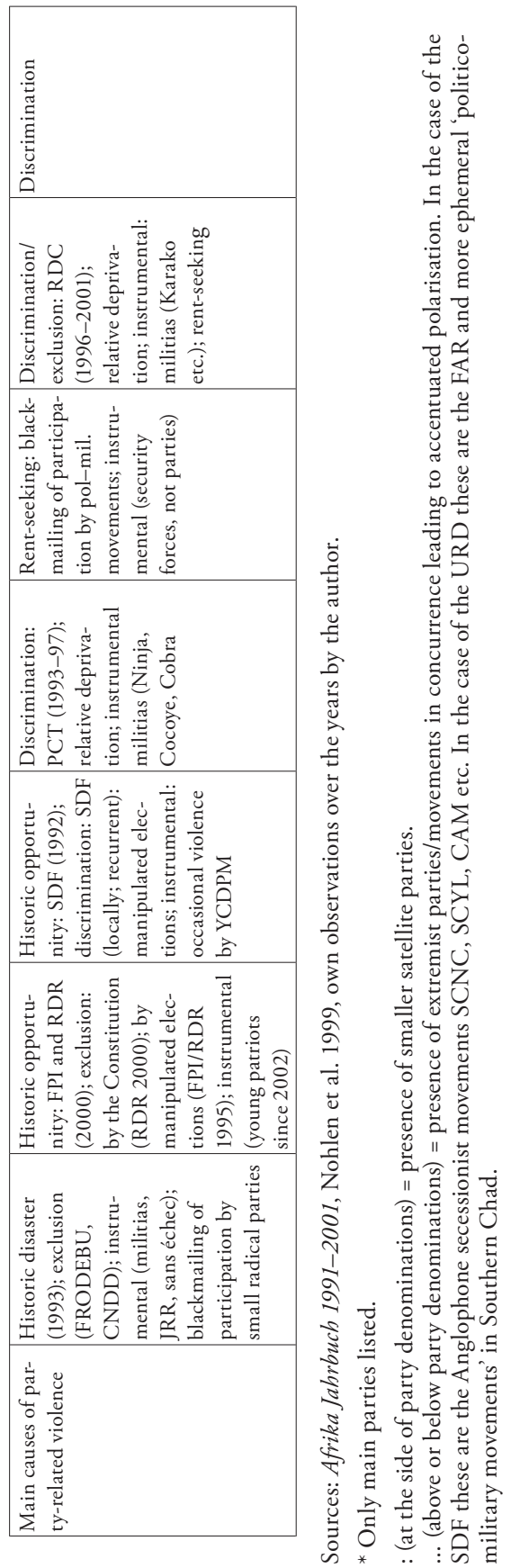


\title{
Insights into Electoral Violence in Africa
}

\author{
Liisa Laakso
}

Much has been achieved in the field of political liberalisation in Africa since the early 1990s largely through the work done by numerous civic and human rights groups, media and international actors. Space for self-initiative organization and the ability to criticise those using public power have increased together with the multiparty electoral competition. Democratisation has proceeded with an improvement in the quality of elections. With the third succeeding elections, parties' participation and competition have increased significantly. However, while complete breakdowns, i.e. violent overthrows following the elections, have been mainly limited to founding elections, news about electoral political violence has not been rare with second and third round elections either. According to Staffan Lindberg's comprehensive study of multiparty elections in Africa ${ }^{2}$ (2004) roughly 80 per cent of the elections witnessed some kind of electoral violence. Most interestingly the elections that were declared free and fair ${ }^{3}$ by election observers were no less violent than elections that were declared not free and fair.

This article aims to clarify the multifaceted phenomenon of electoral violence in Africa by looking at the elections in three African countries: Kenya, Tanzania and Zimbabwe. Their transition processes have varied but they are all examples of political systems mixing authoritarian and democratic elements (see for example the classification of the Freedom House 2003). None of them is a 'pure democracy'; however none of them has

1. This article is based on a paper presented at the AEGIS Thematic Conference, "How people elect their leaders: Parties, party systems and elections in Africa south of the Sahara”, Institut für Afrika-Kunde, Hamburg 22-23 May 2003. I am grateful for all the comments given by the participants and two anonymous referees.

2. The sample included 87 presidential and 116 parliamentary elections: 24 were held efore 1990, 82 between 1990 and 1995 and 97 between 1996 and 2001.

3. Lindberg's categorisation of the highly contested notion of 'free and fair' is based on the reports of election observers. If there were some irregularities but these were not regarded as affecting the results, he classified the elections as being free and fair. 
experienced a violent breakdown of the constitution either, but all have witnessed intense and violent electoral competition.

In Kenya, where the government reintroduced a multiparty system after massive popular pressure and protests, the first and second elections in 1992 and 1997 were accompanied by violence. However, the third elections in 2002 brought opposition parties to power and surprised many by their relative peacefulness. The Tanzanian government, in turn, responded skilfully to the continent-wide wave of democratisation by taking the initiative for transition to multiparty political system in its own hands before there was any widespread discontent against the ruling party. Political stability rather than upheaval has characterised its period of transition - but only on the mainland. The Zanzibar polls have been marred by violence reminding many of the political upheaval in the islands after the independence elections in early 1964.

On the surface Zimbabwe, with a continuous multiparty political system since the end of the liberation struggle and the introduction of majority rule in 1980, would appear as a case of no transition at all. However Zimbabwe, too, experienced a democratic transition during the early 1990s. The Zimbabwean experience was a change of the direction towards which the political system was developing to a difficult status quo. Until 1990 the government had taken gradual steps towards an 'African' one-party state. This plan faced vocal criticism from the civil society at a time when the rest of Africa was moving in the other direction and it was never put into effect. Yet it was not until 2000 and 2002 that the ruling party faced serious political challenge, and the government's response was a violent mobilization of its supporters.

\section{What is electoral violence?}

It is not an easy task to approach electoral violence within such a setting. From the theoretical point of view it makes little sense, since elections in essence should be part of the democratic rules to solve political conflicts without force and violence. Empirically democracy seems to be associated with a reduced risk of violence (Gleditsch and Ward 2000). Democracies can respond to a variety of demands by providing channels for participation and checks and balances to attach accountability to the use of power. Therefore dissatisfaction is seldom expressed in democracies by challenging the whole system; instead democracies facilitate non-violent protest (see Eckstein and Gurr 1975). But the empirical studies also show that the proc- 
ess of democratisation involves risks (Reychler 1999). Transition from one type of regime to another one is revolutionary in itself. Consolidation of the new system takes time. And, indeed, even after third and fourth rounds of competitive elections, Africa is still in a difficult process of transition where elements of democratic participation are intertwined with authoritarian rule and political repression.

'Transitions', of course, are never the same but have to be seen in their particular socio-economic context. In ethnically divided societies, for example, it is not an easy task to design an electoral system satisfying all groups (see Reilly and Reynolds 1999.) This is even more crucial as it is difficult to make a distinction between inadequate governance, the often apparent legitimacy deficit of public institutions and the behaviour of the ruling elite in command of those institutions. Historical experience and ethnic and regional divisions might count more than the institutional setup, i.e. electoral law and the constitutional division of power. Elections can become a zero sum game simply because there is no experience of democratic participation or possibilities to openly criticise the government also after the elections. The experiences might rather include the systematic violation of political rights. Furthermore expectations might be unrealistically high for the elections to bring a 'historical chance' with regard to the marginalization of some groups (Mehler 2003).

Especially if the transition has been preceded by war, parties that lose in the elections can be eager to look for undemocratic means to defend their security, whereas parties gaining government power can interpret all opposition activities as potential rebellion (see Kumar 1998). The failure of the UN-supervised elections in Angola in 1992 to end the conflict there is a case in point. As defined by Adam Przeworski, democracies are systems where political parties know what winning or losing means to them, because the collectively recognized institutional framework determines this, and they also know how likely they are to win or lose, but they never know if they will win or lose (1991: 12-13). Coping with this uncertainty is an important ingredient of democracies. If the only expectation of the competing parties is to win the elections, there is little reason to believe that the elections would bring about democratisation - violence might then be a very logical outcome. Furthermore within a transition from an authoritarian regime, the opportunities for groups to mobilize are new and diverse. The conflicts in the 1990s, particularly in the Balkans and in the former Soviet Union, suggested that a newly established democratic regime might fuel conflicts that had been suppressed during the authoritarian regime 
(Ellingsen and Gleditsch 1997, Muller and Weede 1990). Such destabilizing effects of the transition can be related to several processes challenging the old power structures.

The simple relationship between democratic transition and electoral violence is presented in Figure 1.

Figure 1: Political transition leads to electoral violence

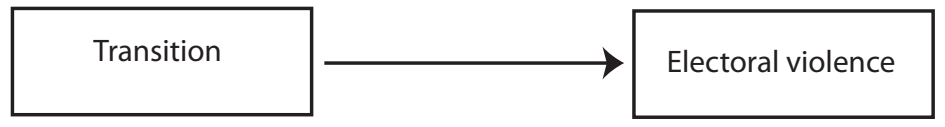

Political violence has played a part in the long transition process in Western democracies, too. Patrick Quantin has noted that France in the 19th century witnessed electoral violence that was not so different from the recent experiences in Africa. His analysis suggests that violence correlates with the meaningfulness of the elections, which, of course, is very high during periods of transition. Violence becomes one form of participation in highly contested elections especially if these occur in a normative vacuum of 'a market place' where all participants try to maximise their 'profits'. This normative vacuum needs to be filled by institutionalisation of the non-violent rules of the game for the electoral system to be consolidated. In other words, electoral competition has to be linked to non-market values, old or new, in order to make it peaceful (Quantin 1998). Such institutionalisation of the rules of the game relates to the overall strength of political institutions. And indeed, the gap between high levels of political participation and weak political institutions was recognized as a major source of political instability in the developing world already in the 1960's (see Huntington 1968).

Many of the recently democratised African countries can be characterised as weak states: their capabilities to design and implement coherent policies are limited and political power is personalised rather than embedded in political institutions. Electoral violence can be a sign of false democratisation with electoral fraud - part of an illegitimate strategy to win elections or an attempt to show the illegitimate nature of the whole electoral process. On the other hand, within 'free and fair' elections, violence can simply be a strategy of 'bad losers' to undermine the position of the winners. And indeed, electoral violence by definition has to be seen as an activity motivated 
by an attempt to affect the results of the elections - either by manipulating the electoral procedures and participation or by contesting the legitimacy of the results. It might involve voters' and candidates' intimidation, killings, attacks against their property, forceful displacement, unlawful detentions and rioting. The timing of the violence (before, during or after the elections) relates to the chosen modes: displacement of voters taking place before elections and violent riots contesting the results after the elections. Before the elections, voters and candidates can be intimidated in order to affect their choices: they might face rather similar techniques as punishments after the elections. Quite paradoxically the actual polling, which is the most keenly monitored phase of the elections, is often the most peaceful period.

The perpetrators of electoral violence vary from government forces (i.e. the police and army) and supporters of the government to opposition groups, spontaneous demonstrators and even rebel organizations that cannot or do not want to take part in the formal political life at all. Both the ruling party and the opposition might use hired thugs and youth wings of their parties. However, it would be a mistake to see these groups only as a passive 'reserve' manipulated by the political leaders. Violent campaigning for the winning party can be a strategy for the marginalised groups to get access to political power after the elections. Ex-guerrillas or war veterans might violently support the party they once fought for - most likely the ruling party. Recent experience of armed struggle means that there are groups that are used to violent tactics. It is only logical that armed movements turned into ruling parties are not very willing to peacefully give away their power at the ballot box.

\section{Economic context of African elections}

The 1990s' wave of democratisation in Africa often coincided with a lack of economic development. Violent political mobilization of groups might reflect economic problems and tensions that played a role in the pressure for transition and in the electoral campaigning, but actually have very little to do with electoral competition and its legitimacy as such. And indeed, there is a well-established association between poverty (measured by such indicators as GNP per capita, life expectancy and literacy, for instance) and political violence (Gurr and Duvall 1973: 158, Collier and Hoeffler 1998). Because of poverty, less serious disputes, like those concerning electoral 
procedures, can lead to open violence (Figure 2). People who have little to lose are easily mobilised to violent actions.

Figure 2: Economic stress leads to electoral violence.

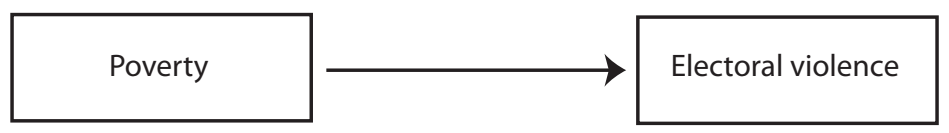

Poverty, of course, is a relative concept. What matters most for individuals and groups is the gap between their expected and actual welfare. Low growth rates as such do not hinder development and, on the other hand, growth can be linked with increasing inequality. As noted by Amartaya Sen, rising living standards in a society as a whole may lead to an increase in poverty in terms of relative deprivation (Sen 1976). Even the relationship between inequality and political unrest is complicated and affected by many other factors (see Lichbach 1989). Therefore a socio-economic crisis, however severe it may be, should not be seen as an explanans or sufficient cause for violence. There are examples of countries experiencing poverty and economic crisis but no electoral violence. On the other hand there are also countries where steady growth has not prevented electoral violence - Equatorial Guinea in 2000, the fastest-growing economy in Africa, being a case in point.

What is true, however, is that African economies have been vulnerable to changes in the economic status of different groups. A variety of reasons have contributed to it, including the drastic experiments of structural adjustment in the late 1980s and early 1990s, lack of economic diversification and dependency on the export earnings of a few raw materials or agricultural products, whose prices tend to fluctuate in the world markets. An unexpected decline of welfare leads to desperation, which is among the most common sources of conflicts anywhere in the world (Auvinen 1996, Gurr 1970). Fading perspectives of a better future can be particularly devastating to young people. And indeed, the extreme brutality of some of the rebel movements towards peasants can be understood as reflecting the serious socio-economic crisis hitting the urban youth. The rebel movements originate from the mobilization of the disgruntled urban youth, while they have to operate in the rural areas where the state security forces are not so much present, but where the people are not supportive to their motivations (Mkandawire 2002). 
Furthermore, parts of Africa are vulnerable to opportunistic violence and exploitation of the criminalized economy for the personal enrichment of rebels and/or political leaders (Collier and Hoeffler 1998). Corruption also has its linkages to violence by undermining the rule of law and by making the smooth democratic change of government difficult, as the defeated ruling elite would lose much more than political power only, including their impunity. If the rulers are afraid of losing power, they may apply violent and repressive measures to eliminate opposition in order to preserve their own security. The other side of the coin is that, because a weak state has limited capabilities, opposition groups can be particularly eager to resist it through violent rebellion (Kivimäki and Laakso 2003).

\section{Kenya: ethnic politics and violence}

In Kenya the first multiparty elections since the early independence period were held in 1992 and the second in 1997. Both were won by the ruling Kenya African National Union (KANU) and both were accompanied by violence. But the third elections in December 2002, which brought to power opposition parties, the National Rainbow Coalition (NARC) and Democratic Party's Mwai Kibaki, surprised many by their peacefulness - yet violence was not totally absent from these elections either.

\section{Economic stress and pressure for transition}

In Kenya the main mobilizing force for the abandonment of the de jure one-party state was the informal sector and the unemployed youth. The socio-economic crisis and rising unemployment marked a contrast with the positive development trend of the first two decades after independence. Multipartyism, however, brought no improvements (Holmquist 2002). According to the government of Kenya, in 1973 the number of poor was 3.7 million, but by 2000 it had grown to 15 million. Between 1992 and 2000 , the overall national incidence of poverty was estimated to have increased from $45 \%$ to $56 \%$. (Kenya 2000.) About $62 \%$ of the population was living below the very rough income poverty line of 2 US\$ per day. The Human Development Index (HDI) deteriorated from 0.533 in 1990 to 0.513 in 2002. (UNDP 2002: tables 2 and 3.) Gross inequality of income distribution is also evident: in 1994 the poorest $20 \%$ of the rural population in Kenya received only $3.5 \%$ of the national income, while the richest $10 \%$ of Kenyans garnered $48 \%$ of the income. Income concentration in Kenya is among the highest in the world (UNDP 1999). 
The accountability of public authorities was not enhanced either. Kenya has been frequently ranked among the most corrupt countries in the world (Transparency International 2005: 169-172). This has contributed to the unstable macro-economic performance. The 1992 elections were preceded by a massive increase in money supply, which led to inflation and a net outflow of foreign exchange. It is thus not surprising that popular discontent with president Moi's regime increased throughout the 1990s in spite of its success in the 1992 and 1997 elections.

Violent campaigning of the party youth played a part in the electoral strategy of KANU, but it also instigated similar tactics on the part of the opposition and was not absent from the intra-party competition either. Most serious incidents related to ethnic cleansing operations (Klopp 2001). The role of government officials in organizing and financing those operations is well documented by human rights groups and even the government's own parliamentary committee.

\section{Youth security organs and political campaigning}

Before the 1992 multiparty elections, KANU organized its youth wing as the 'security organ' for the party. Elite members of the wing constituted Youth for KANU (YK '92). YK '92 and Operation Moi Win (OMW) became the main organs of KANU campaigns. With the backing of the provincial administration, they conducted campaigns in the opposition strongholds and fenced off the opposition from KANU strongholds. The leader of the YK '92 Cyrus Jirongo, a young businessman, assumed a very important role in the party - even to the extent that senior ministers could be seen outside his office queuing for campaign money and support. People even named the new five hundred shilling note 'Jirongo', since it was introduced at the height of the campaigns. Through YK '92 the youth leaders accumulated considerable wealth. YK ' 92 and OMW were disbanded immediately after the elections. In addition, the government sequestered Jirongo's firms and private property. Some of the senior KANU politicians had clearly become worried about the central political position that he and his associates had occupied.

The second multiparty elections held in 1997 saw the rise of another KANU youth organization, Jeshi la Mzee (the old man's army) that claimed to be president Moi's unofficial militia. It was supported by the police and financed from senior KANU elites, which enabled it to hand out daily payments for its members. (KHRC Quarterly Repression Reports April-June 
1997.) An important part of its membership came from the Luhya ethnic group in Nairobi. The leaders were KANU youth wing members who had close relations with a Luhya politician Fred Gumo, who also financed the organizations. Jeshi la Mzee was instrumental for Gumo to gain leverage in the intra-KANU rivalry for the party's nomination of parliamentary election candidates in Nairobi.

During the campaigning period Jeshi la Mzee disrupted opposition meetings. In Nairobi the pro-reform or opposition youth groups were a majority but lacked one organizational structure. Thus they tended to react to, rather than organise against, Jeshi la Mzee. Their slogan was 'change' including Ford-Kenya's (a party dominated by the Luo ethnic group) Operation Moi Out (OMO). All parties formed some kind of security groups by hiring unemployed youth, whose task was to protect their candidates and to prevent others from disrupting their meetings. Violent clashes between the youth wings of rival parties became a common phenomenon. Within just two weeks before the 1997 elections, for example, eight people were killed and more than 100 injured in such clashes (East African Standard 29 December 1997).

\section{Ethnic cleansing in 1992 and 1997}

In Rift Valley, where most serious ethnic cleansing operations took place during the 1992 elections, local KANU politicians started to instigate intimidation of 'opposition tribes' as early as in October 1991. ${ }^{1}$ In political rallies politicians advocated for a federal system of government (Majimboism) and argued that Rift Valley was for the Maasai and Kalenjins, which is president Moi's ethnic group, and KANU. Therefore supporters of opposition parties should leave the province. (Cowen and Kanyinga 2002.)

Clashes that followed these rallies were financed, armed and organised by a trained militia. According to the Parliamentary Select Committee that investigated the clashes, the militia had paid 1,000 Ksh for every person killed, 500 Ksh for every grass-thatched house torched and 10,000 Ksh for every permanent house burnt (Daily Nation 7 August 1998). During 1992, some 2,000 people were killed and 20,000 were made homeless. The fighting continued in early 1993. Altogether about 300,000 Kikuyu and Luo farmers were displaced. (HRW 1993, Kuria 1994.)

1. Land ownership in the area had been volatile since colonial times, when British settlers had employed labourers for their farms from outside the area. 
The comprehensive report of the Judicial Commission that was appointed to inquire into 'Tribal Clashes in Kenya' was published only after an order by the High Court in October 2002. According to the report, cabinet ministers armed the militias and gave them instructions. The most prominent figure that is named is Nicholas Biwott, the then trade minister and Moi's close political associate. The government, however, argued that the report was biased against the Kalenjin and Maasai, and ignored the role played by other groups such as the Kikuyu.

In 1997 ethnic cleansing was conducted in the Coast Province in the Likoni and Kwale areas south of Mombasa. The apparent purpose again was to displace potential opposition voters. From mid-August to early November there was a series of violent attacks targeting the upcountry people', Luo, Kikuyu and Kamba ethnic groups, who had migrated to the area due to the lucrative tourism industry as well as the government's settlement schemes. In the attacks more than a hundred people were killed, an unknown number of men beaten, women and girls raped, while tens of shops, kiosks, bars and houses were looted and burned. About 100,000 people left Mombasa for the election period. The mere fact that the election day was between the Christmas and New Year holidays meant that even those intending to return finally spent the holiday season with their relatives in the upcountry areas. The final voters' turnout in Likoni constituency was only 37 per cent (see The Nation Election '97 Website: Results).

Some authors have argued that the main motive of the cleansing was the president's desire to ensure his victory by getting at least the threshold of 25 per cent of votes in Coast Province. ${ }^{1}$ Among the 'upcountry people' at the coast, the Kamba constituted the biggest group. Because one of the presidential candidates, the Social Democratic Party's Charity Ngilu, who had done well in the opinion polls, was a Kamba, there was a possibility that Moi would lose to Ngilu in Coast Province and would not be able to ensure even the 25 per cent threshold of the votes (Cowen and Ngunyi 1997: 27-31.) The attacks, however, were not merely targeted against the Kamba, and the final election results showed that Ngilu's support in the whole country, the coast included, remained well below some of the early estimates.

It might be that the local KANU politicians were more concerned than the president of the ethnic composition of the coast constituencies. Motivations stemming from national and presidential politics were probably

1. According to the Presidential Elections Act, to be elected the winning candidate has to get at least $25 \%$ of the votes in five of the country's eight provinces. 
more connected to the pressure for constitutional reform among opposition parties and civil society. The organization of the Likoni-Kwale raids had already started in May 1997, when it must have appeared to many KANU politicians that constitutional reform enhancing the possibilities of the opposition in the forthcoming election was going ahead. In that case the only alternative for them to retain power would have been to postpone the elections forever. This, in turn, would have been possible only by declaring a state of emergency most easily justified by ethnic clashes. However, by mid-September, KANU was able to capture the constitutional reform by dividing the opposition. At that time the police also took more resolute steps to stop the violence in Likoni and Kwale. Simultaneously the nonlocal support of the raiders was withdrawn (KHRC 1998: 28-29, 50-53) and the raids became much more undisciplined.

Early reports already linked the violence to KANU (see Daily Nation 21 August 1997). Local KANU leaders recruited Hutu refugees, other expatriates and non-locals to the ranks of the raiders, while the majority of them came from the indigenous local Digo ethnic group. The Digo recruits were unemployed school dropouts, whose grievances were connected to their Muslim identity and the general feeling of marginalization among the Muslim community. In spite of being the majority, the Digo felt excluded from the economic development of the area. (KHRC 1998.)

According to the interviews carried out by Kenya Human Rights Commission, most of the young recruits were first contacted by their friends. They were given a small amount of money and taken to a training camp in a nearby forest, where a group of ex-servicemen provided them with basic training. The youth were told that their mission was to introduce Majimbo and to get rid of the 'upcountry people' in their area. They were told that the government and the president backed the mission, because the 'upcountry people' were supporters of the opposition. After the polls the recruits would be rewarded with generous payments. All of them had to participate in a ritual oath supposedly to instil them with courage and to give them protection. During the summer, the 'secret' that oaths were being administered for Majimbo was widespread and many young men in the area wanted to join the mission (KHRC 1998: 21-25).

In the attacks most of the victims were Luo. According to rumours, the raiders were offered 20,000 Ksh for each Luo they killed and 10,000 Ksh for each Kikuyu (FIDH 1997: 8). But descriptions of the attacks showed that there was also antagonism against non-Digo indigenous people. On the other hand, in some cases people were saved if they were Muslims. In 
addition, in the attacks some Digos were also killed and their houses were burned. If anything, this says that the 'ethnic conflict' was not unambiguous and that at least at some point the whole operation turned out to be more or less anarchic. (KHRC 1998: 19, 30-32.)

The government responded to the situation with an arbitrary intimidation of Digos. However, even influential politicians who had supported the operation were detained. These included Omar Masumbuko, who was the former leader of the Youth for KANU '92 in Coast Province. Since 1992 he had led a group called United Muslims of Africa (UMA), which was close to KANU and had terrorised other Islamic groups in the area with the apparent complicity of the police.

Rift Valley, too, witnessed ethnic violence just before and after the 1997 elections, for example in the predominantly Kikuyu Laikipia. Unlike in 1992, this time smallholders organised counter-attacks and violence spread to Nakuru, too. By February 1998, about two hundred people had died and many more were injured.

\section{Elections in 2002}

Before the 2002 elections, reports on serious tensions appeared again. At least twenty people died in violent election campaigning (EUEOM 2002: 23). Particularly in Rift Valley militias armed with crude weapons were again active. During the summer youth groups destroyed makeshift homes and stalls of people across the country without the interference of police. Thousands were forced to flee during the looting that followed.

The nomination of KANU's presidential candidate was full of tensions. According as the constitution, president Moi had to step down. Moi's choice as his successor was Uhuru Kenyatta, son of the first president. This time Kikuyu youth groups called Mungiki (a united people) became active and they enjoyed at least some support among the KANU leaders. This mysterious and violent anti-Western religious sect was inspired by the Kikuyu Mau Mau rebellion against the British colonial rule in the 1950s and had emerged as part of the youth protest mobilization during the late 1980s (K'Amolo 2003). Although the police had earlier frequently confronted the group, during the summer of 2002 it was no longer seen interfering in Mungiki activities.

The group disrupted KANU rallies, where Kenyatta's candidacy was opposed. The most important opponent was Raila Odinga, who with his National Development Party (NDP) had joined KANU in the hope of be- 
coming the party's presidential candidate. NDP had been the third largest party in parliament and was supported by the Luo. Finally Uhuru Kenyatta was nominated as presidential candidate and Raila Odinga joined the opposition.

Mungiki leaders warned that there would be violence if voters elected anyone other than Kenyatta. Carrying crude weapons they paraded through the streets of Nairobi. The government banned Mungiki, but they continued to operate as before. However, the uneasy relation between KANU and the group became evident as their national chairman, Maina Njenga, was initially chosen as KANU's candidate in the Laikipia West seat in Rift Valley but he was replaced by the party with another candidate which led to Mungiki protests at the official nomination of the candidate (East African Standard 12 January 2003).

On the opposition side, the process that led to the formation of NARC, a wide coalition of parties, was not smooth either. The coalition meant that each constituency could have only one NARC candidate. The rivalry between aspiring opposition candidates from different parties was rife during the official nomination. Irregularities during the nomination were not a new thing (and, as the case of Mungiki chairman Njenga showed, permeated the KANU nominations as well). Youth groups were seen fighting with stones and sticks during some of the nomination processes. Some of the candidates were beaten so badly that they had to be taken to hospital.

There were also reports of clashes between KANU and the opposition youths during the actual campaigning. But there were no systematic ethnic cleansing operations. The big cities, Nairobi and Mombasa, were calmer than they had been before the previous elections. Several factors distinguished the political setting of these elections from the previous ones. First of all both the ruling party's presidential candidate and the candidate of its main challenger NARC, were Kikuyu. ${ }^{1}$ If identity politics mattered as a mobilizing force behind violent campaigning, it was only logical that the 2002 elections were peaceful.

Secondly, this time the opposition parties managed to build up a coalition. The KANU majority in parliament had depended on only a few seats. In 1992 and 1997 the support of the opposition parties had been much stronger, but their split had enabled KANU to win. In 2002 it might have

1. NARC's Mwai Kibaki, a wealthy businessman, had been an MP since 1963, finance minister under Jomo Kenyatta and vice-president (1978-1988). After the transition to a multiparty system, Kibaki established the Democratic Party (DP) that became the second biggest party in parliament. 
appeared evident for many that even with voter intimidation KANU could not win this time.

Thirdly, Kenyan civil society and Kenyans at large had learned from the previous elections. Kenya Human Rights Commission conducted a civic education project in order to enhance awareness of electoral violence and its prevention. Reporting the use of political violence was more extensive than ever before. The Electoral Violence Monitoring Project covered the pre-election, election and post-election periods. This kind of mobilization against violence indicates institutionalisation of the non-violent rules of the game.

\section{Tanzania: protest and repression in Zanzibar}

It is noteworthy that Tanzania had already held competitive elections already under the one-party system and that, unlike in Kenya, ethnicity had not become a major political factor in Tanzania. However, there was and is one volatile division in Tanzania: the union between mainland Tanganyika having a population of around 30 million and Zanzibar composed of Pemba and Unguja islands with around one million inhabitants. During the one-party period, open dissent to the union was repressed. Transition to multipartyism brought the issue to the surface of national politics but provided no easy solution to it. The first elections after the transition were held in 1995 and the second in 2000. The ruling party Chama cha Mapinduzi (CCM) won both elections. Unlike in the mainland in Zanzibar the polls were marred by accusations of vote rigging and violence.

\section{Violent electoral history in Zanzibar}

The end of the British colonial rule in Zanzibar was marred by competition between two nationalist coalitions, exacerbating the antagonisms between Africans and Arabs living in the islands. The Zanzibar Nationalist Party (ZNP), which was dominated by Arabs, argued that the African migrants from the mainland should be excluded from citizenship and voting rights. The Afro-Shirazi Party (ASP) representing the African population, in turn, accused the ZNP of trying to preserve the Arab economic and political supremacy. However, since less than 20 percent of the population regarded themselves as Arabs ZNP had to form a multiracial coalition by making appeals to Islamic unity among Africans of long Zanzibari descent, the "Shirazi" (Burgess 1999: 32). 
In the pre-independence elections for the legislative council in 1957, the ASP won by an overwhelming majority. However, in the elections of 1963 the coalition of ZNP and its offshoot the Zanzibar and Pemba People's party (ZPPP) took a majority of the seats, even though the ASP polled 54 percent of the popular vote in the majoritarian electoral system. At independence, power was handed over to the ZNP/ZPPP coalition and the constitution stipulated that the Sultan was the sovereign head of state. The ASP was bitter and, unlike the party leadership, its Youth League saw violence as the only way to respond to the situation. The violent revolution that followed in January 1964 was planned and executed by the youth and thus was not just about Arabs and Africans, but also about elders and youth. As noted by Thomas Burgess, 'youth' was a political identity that expressed marginalization, lack of wealth and social rank. Afterwards the ASP Youth League and its leader Seif Bakhari transferred power over to the ASP 'elders' and Abeid Karume (Burgess 1999: 30). The multi-party system was abolished. In April 1964 a union between Zanzibar and Tanganyika was established. The constitution gave Zanzibar control over its internal affairs and stipulated that its president was to be the Union's vice president. In addition to being represented in the union parliament, Zanzibar also got its own parliament.

The suspected supporters of the ZNP regime faced imprisonment, violence, confiscation of property and different kinds of discrimination. The ASP Youth League was often the perpetrator. Karume was killed in 1972 in a failed coup attempt, and the more moderate Aboud Jumbe was elected as the new leader. Jumbe then removed Bakhari from the islands to a position in the Union government. Only then was the ASP able to dismantle most Youth League departments, ending its role as the enforcing agency (Burgess 1999: 44). In 1977 the ASP and Tanganyika African Nationalist Union (TANU) merged into CCM.

\section{Economic recession}

Although once a wealthy area having trade relations all over the world, Zanzibar has been very dependent on one crop only: cloves. Revenue from this source has declined due to price instability and decrease in production. Zanzibar's balance of trade had turned negative by 1981 and has not yet recovered. Foreign donors, being encouraged by the economic liberalization, increased their aid to Zanzibar in the mid-1980s but withdrew it after accusations of vote rigging in the 1995 elections (Chachage 1998). 
Tanzania with a per capita GDP of about 600 US\$ is one of the poorest countries in the world, but Zanzibar's per capita GDP is almost three times lower: 220 US\$ (GOZ 2003, 35). Infant mortality is 83 per 1,000 and life expectancy is 48 years (IMF 2003: table 31). The illiteracy rate is very high: 40 per cent, while primary enrolment is only 67 per cent. About 61 per cent of Zanzibaris were without basic livelihood needs in 2003. The situation is worst in Pemba (GOZ 2003: 28, 29). Pemba, which produces the bulk of the cloves, is poorer and less developed than Unguja. It also has a large population of Arab origin. It is thus not surprising that disappointment at the continuing rule of CCM has been particularly widespread in Pemba.

\section{Post-election violence}

In 1995 the ruling CCM party won easily on the mainland but in Zanzibar it faced a strong challenge from the opposition Civic United Front (CUF) associated with the old base of the ZNP which received support particularly in Pemba and from those segments of the population who had suffered from the economic recession. In the 1995 elections, the support for the parties cannot only be explained by the Arab-African ethnic divide but also involved local divisions (Sheriff 2001: 301-318). CUF favoured amendments to the constitution to balance the federation, like the establishment of three parliaments: one for the mainland, one for Zanzibar, and one for the Union. Some elements in CUF openly advocated secession.

According to the official results which were announced very late and after rumours of manipulation were already rampant, the ruling party's candidate won the presidential elections by less than half a percent beating CUF's candidate. CUF denounced the elections as rigged, which was supported by the donor community. It refused to participate in the new government and did not take up its parliamentary seats. The pressure did not lead to new elections. Frustration and protest were evident in isolated violent actions against public property, but there were no demonstrations or strikes. In an attempt to contain the situation, the government detained the CUF leaders and restricted the freedom of the press (Bakari 2002).

The pressure by the international donor community did not bring positive results and a peace accord, brokered by the Commonwealth and signed in 1999, was never put into practice (CCM and CUF 1999). Unlawful detentions and intimidation of CUF members continued. Before the 2000 elections the government deployed more troops from the mainland. The campaign period was tense. For instance in CUF's final campaign rally, 
party youth were seen with stones in their hands (Cameron 2001: 321). Throughout the campaigning, CUF claimed that the police harassed its supporters.

On October 29, 2000, 10 million voters in 231 constituencies cast their votes for 13 political parties throughout Tanzania. The election on the Tanzanian mainland was won by CCM against a divided and weak opposition. In Zanzibar, the arrangements were chaotic, because ballot papers and other election materials failed to arrive in time to all the polling stations. Demonstrations followed and police and army units made arrests. The Zanzibar Electoral Commission (ZEC) suspended voting and ordered a re-run of the elections in 16 constituencies. Finally after the rerun, the ZEC declared a narrow victory for CCM's presidential candidate. CUF and international observers again denounced the official results. CUF again refused to take up its seats in parliament. Instead it demanded new elections under a reformed and impartial electoral commission. Violent protests also followed, although it remains unclear who organised them. There were even several bomb explosions, including one which destroyed ZEC offices (East African 1 January 2001).

On January 27, 2001, throughout the major cities of Tanzania, there were mass protests. The government responded by banning the demonstrations by the CUF and arrested its chairman, Ibrahim Lipumba. The paramilitary police brought from the mainland killed tens of people and wounded hundreds in Zanzibar. Thousands fled to the mainland and about 2,000 Pembans fled to Kenya. The police continued harassing civilians long after the demonstrations. The government restricted the freedom of the press and even stripped four opposition leaders of their citizenship (HRW 2002, Cameron 2002).

In October 2001 CCM and CUF signed an accord that was described by Human Rights Watch as 'an important step towards ending the longstanding hostility between the Tanzanian government and the political opposition' (HRW 2002). The government nominated a commission in January 2002 to investigate the Zanzibar clashes. It announced its findings in July 2002. Ibrahim Lipumba, however, quickly described the report as shallow and a government whitewash. The accord also stipulated constitutional and electoral reforms in order to separate the government from the ruling party's structures, and strengthen the impartiality of the ZEC and the Zanzibar judiciary. But the implementation was again hampered by its dependence on the political will of the ruling party (see Hirschler 2001). 


\section{Zimbabwe: Violent politicisation of the land issue}

The end of the liberation war and introduction of majority rule in Zimbabwe was followed by violent repression and conflict in the south-eastern part of the country, in Matabeleland, the stronghold of the second biggest party, Zimbabwe People's Union (ZAPU). This conflict did not end before 1987, when ZAPU was merged with the ruling party, the Zimbabwe African National Union-Patriotic Front, ZANU(PF), creating a de facto oneparty state. The government, however, did not introduce a de jure one party system. As a result an increasingly vocal civil society has coexisted with an unaccomplished one-party state, where $\mathrm{ZANU}(\mathrm{PF})$ was determined to rule the country but had to adjust to the constant possibility of party competition in all forthcoming elections. Thus the government has repressed all political opposition. As long as this opposition was tiny the repression did not turn violent, a few incidents notwithstanding.

While it is very easy to see continuities in the violent strategies of ZANU(PF) toward its opposition throughout the independence era and also to 'explain' this by the violent guerrilla mobilization within the same movement during the liberation struggle (Kriger 2005), it is impossible to understand the strength of the opposition firstly without the 'transition' that took place when the ruling party abandoned its plans to establish a one party state and the very real space that was opened up for the civil society, and secondly without the very drastic and unsuccessful implementation of the structural adjustment programme in an economy that had originally been diversified under the international sanctions against the Rhodesian minority rule and had been protected since then.

\section{Economic crisis and discontent}

In spite of a quite promising start and high expectations during the 1980s, the Zimbabwean economy recessed throughout the 1990s exacerbated by the 1992 drought. In 1990, the government launched the Economic and Structural Adjustment Programme (ESAP). At that time Zimbabwe was not in large-scale economic distress: annual growth averaged 3.4 per cent during the 1980s, although it had not been fast enough to absorb a rapidly growing labour force nor sufficient to generate the tax revenues necessary for continued expansion in health and education services. With the liberalization of markets and measures to reduce fiscal deficit, ESAP was an attempt to reinvigorate the economy and attract foreign investments. However, the decision led to a situation where the private sector was faced with 
two shocks: price competition in the domestic market after import liberalization and very high interest rates. This meant that enterprises could not take loans and invest in restructuring their production. Companies that had been well managed until then ended up bankrupt. Mass unemployment followed (Addison \& Laakso 2003).

The Human Development Index in 1985 was 0.621 , but dropped to 0.551 in 2000 . About 64 per cent of the people lived below the income poverty line of 2 US\$ per day (UNDP 2002: tables 2 and 3). High inflation hit the urban population especially hard. This mobilized the middle class and the trade union movement. Harare saw regular public-sector strikes during the second half of the 1990s, as well as food riots by the urban poor. By the same token popular support for a new opposition was created.

The veterans of the liberation struggle, ideologically and politically an important group for the ruling party, also became disgruntled as they had received very little after independence. They demanded compensation for their wartime sacrifices and in 1997 president Mugabe suddenly promised a pension and free education and health care to the 60,000 war veterans. This was to be financed by an extra 5\% levy. In response the trade union movement organized the largest mass action ever seen in the country. From then on trade unionists and veterans' organizations were seen as opposing each other - notwithstanding the fact that there are war veterans among the workers, too. The anger of the labour union and civic groups towards the government worsened in August 1998, when president Mugabe (again without consulting his cabinet) decided to send Zimbabwean troops to the Democratic Republic of Congo.

The civil society groups formed the National Constitutional Assembly (NCA) under the chairmanship of labour union leader Morgan Tsvangirai. It advocated constitutional reforms to check the powers of the president, but the reform process was co-opted and toppled by the government. This gave birth to a new opposition party the Movement for Democratic Change (MDC) in 1999. MDC brought together very different segments of the society and interest groups, including the labour union and white farmers and business people, united merely by their will to end the rule of ZANU(PF). So far it was the strongest opposition party ever to challenge the position of ZANU(PF) (Laakso 2003).

When the government presented its new constitutional proposal in December 1999, NCA and MDC launched a campaign to explain to the public that the changes reducing the powers of the president were merely cosmetic and that much more radical changes were needed. To the govern- 
ment's surprise voters rejected the commission's proposal. This was the first time since independence that the government lost at the polling booths. In the build-up to the parliamentary elections in 2000 and presidential elections in 2002 the country witnessed a new wave of political violence. Political violence continued to the parliamentary elections in 2005. Tens of people were killed during the campaigning and violence continued after the elections. While the numbers are not very high when compared to Kenyan elections in the 1990s, for instance, the consequences of the violence for the already troubled economy and food security have been devastating.

\section{Mobilization of war veterans' support for the ruling party}

The government mobilised its supporters, especially the War Veterans' Association, for violent actions against the opposition around the land issue. The end of white-minority rule left Zimbabwe with a very unequal distribution of land and the government had not been able to fulfil its early promises of land redistribution. Peasant families living in the overcrowded Communal Areas (former African reserves) constituted more than half of the population (12 million), while about 4,000 large-scale farmers, most of them whites, produced the bulk of the country's export earnings (Moyo 2000). ${ }^{1}$

Shortly after the referendum the government provided funds to the War Veterans' Association to hire unemployed youths in order to campaign for the ruling party before the parliamentary elections (Good 2002: 14). The veterans organized occupations of large farms owned by whites, among them known supporters of the MDC. These farms became bases for the veterans from which they intimidated farm workers and the rural middle class, in particular teachers and health workers, who were likely supporters of the opposition. They were forced to attend political education meetings of $\mathrm{ZANU}(\mathrm{PF})$ which resembled the time of the liberation struggle. Many were disenfranchised when the veterans confiscated their identity documents or forced them to leave their home constituencies. Thousands

1. However, although the ZANU(PF) electoral slogan in 2002 was 'land is the economy and the economy is the land', according to one survey study only $9 \%$ of Zimbabweans thought that land was the most important issue the government had to deal with (the state of the economy was seen as much more important). Only $2 \%$ of Zimbabweans blamed the whites for the country's economic problems (Johnson 2000: table 16), but Mugabe declared them 'the enemy' of the nation (Financial Gazette 4 May 2000). Many whites had openly backed the MDC. 
of peasants were displaced and rural teachers fled for the towns. The veterans also threatened to go back to war if the government lost the elections. (Laakso 2002.)

The government denied any involvement in the violence. Yet army trucks and government vehicles were utilised and some of the weapons came from the military. The police took very little action to protect either the lives or the property of the farmers and farm workers. Mugabe publicly backed the farm occupations and criticised judges who ordered the veterans to leave the farms.

In the parliamentary election in 2000 the polling was held relatively peacefully and the opposition was also able to participate. ZANU(PF) won the elections narrowly over MDC. The regional results showed that the more intimidation during the campaign the better the performance of ZANU. As a result MDC brought legal challenges in 40 constituencies.

However, the relationship between ZANU(PF) and the war veterans was complicated. It was not entirely clear to what extent ZANU(PF) was able to control them. At one point the veterans for example declared that they would redistribute the land by themselves, as politicians could not be relied upon to do the job ( $B B C 8$ May 2000). The army tried to take greater control of them by assimilating them into the Defence Forces as reserves. In this way the state also tried to audit the administrative affairs of the veterans' companies, as rumours of corruption in them was rampant. The army also wanted the battle experiences of each veteran to be recorded, which would have been a disadvantage for the newly recruited young men. Many ZANU(PF) politicians were also troubled by the eagerness of the veterans to seek party nomination in the elections.

\section{Presidential elections in 2002}

The forceful occupation of farms continued along with considerable violence and population displacement ahead of the presidential elections. General Vitalis Zvinavashe said that Zimbabwe's defence forces would accept only a president who had participated in the liberation war, implying that election of the leader of the MDC, Morgan Tsvangirai, who was a student during the 1970 s, would lead to a military coup.

The battle for the souls of the youth was rife. By opening up the possibility of 'change' - its simple slogan during the election campaign-the MDC was giving hope especially to the educated youth in the urban areas. The enthusiasm with which young MDC supporters displayed their red 
plastic cards during protests signalled mobilization that was very powerful. One sign of the government being aware that most of the youth supported the opposition was an attempt to disenfranchise the first-time voters by not issuing their ID cards in time (Zimbabwe Human Rights NGO Forum 2002).

In order to institutionalise the war veterans' youth militias the government introduced the so-called National Youth Service programme recruiting mostly uneducated youth. The programme started with the establishment of a training centre, where the youth were taught military tactics and the history of the liberation war emphasising the role of ZANU(PF). Their instructors were retired army and police officers and former freedom fighters. 'Green Bombers', 'green shirts', 'bandits' and 'terrorists', as the trained youths were known in high-density suburbs, soon assisted war veterans in the terror campaign. The militias extended their attacks from rural areas to urban businesses, demanding money from employers under the guise of 'settling' labour disputes; many companies shut down as a result. The youth militias set up illegal roadblocks in order to demand ZANU(PF) party membership cards and confiscated identity cards from those who did not have party cards - thus disenfranchising potential opposition supporters (Zimbabwe Human Rights NGO Forum 2002).

When the March 2002 presidential elections finally took place, the number of voting stations in urban areas (where MDC was particularly strong) was cut to half their 2000 level, leaving many people unable to vote. MDC again rejected the results that showed a narrow victory for the ruling party. The youth continued to harass the people. Many were disappointed, as they were not rewarded with money or jobs in the police or army as they were promised. As a result some of them looted shops, attacked even government property and threatened to take action against the ruling party (Daily News 29 April 2002).

\section{Operation Murambatsvina after the parliamentary elections in 2005}

The campaigning for the 2005 parliamentary elections was again marred by harassment of the opposition, though the actual polling day, March 31, was relatively calm. ZANU(PF) won two thirds of the vote and the results were again rejected by the MDC which won only 41 seats. What followed 48 days after the elections was 'Operation Murambatsvina' (Drive out rubbish), officially to restore order in Zimbabwe's cities, where support for MDC was strongest and anti-government riots had taken place. The 
hastily and illegally implemented operation was widely seen as harassment of urban voters and an attempt by the government to force the supporters of the MDC to go to rural areas, which are the stronghold of ZANU(PF).

However, the eviction of $\mathrm{ZANU}(\mathrm{PF})$ supporters and war veterans too from their houses built on occupied farms showed that Operation Murambatsvina cannot simply be described as punishment for opposition voters. Thus one of the political motivations behind the operations was probably also to check the power and influence of the war veterans within the ruling party (UN 2005, 19).

As noted in the report by UN special envoy Anna Tibaijuka, the operation has led to 'untold human suffering' as over half a million people were suddenly made homeless which also disrupted the livelihoods of millions of people (UN 2005: 71). While the operation has also exacerbated the political tensions in the country, even within $\mathrm{ZANU}(\mathrm{PF})$ and the government, and between Zimbabwe and the international community, it has also demonstrated the enforcement power of a failing state.

\section{Conclusions}

While the transition periods have been very different in Kenya, Zanzibar and Zimbabwe, violence in all of them has accompanied electoral victories of the ruling parties. The 2002 elections in Kenya were won by the opposition, but they also surprised many by their peacefulness. This, however, should not be interpreted as that the ruling party's chances depend on the level of violence it can employ in the elections. On the contrary, it might well be that even with considerable use of force KANU could not have won the 2002 elections. In mainland Tanzania, the ruling party's ability to maintain its position has not instigated accusations of vote rigging and violence.

In Kenya the opposition had learned from the previous elections. It was able to make a strategic coalition to challenge the ruling party. Simultaneously the ruling party made a conscious effort to come closer to the opposition ethnic group of the Kikuyu, which in a peculiar way drew the competition inside this biggest ethnic group in the country - not very differently from the eagerness of the parties in the West to attract the centre of the ideological political spectrum. Ethnic divisions in the 2002 presidential elections were not as visible as they had been in the 1992 and 1997 elections. This probably had a pacifying effect on the campaigning and 
Figure 3. Context of the transition

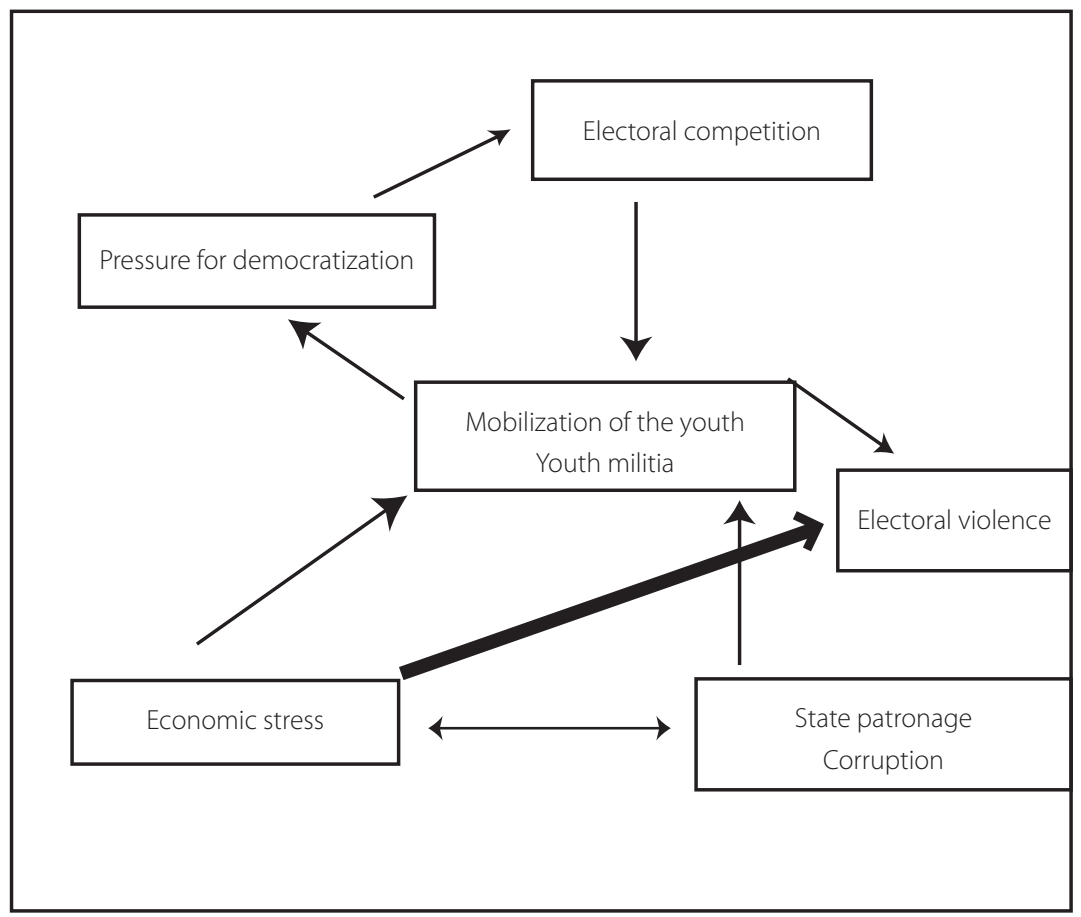

the massive ethnic cleansing operations of the previous elections were not repeated.

Electoral violence in Kenya and Zimbabwe shares some similar characteristics. In both countries the ruling parties tried to influence the campaigning instead of rigging the vote counting. Both avoided the direct use of police or the army but instead supported militia groups. KANU politicians used ethnic militia, and the youth groups of YK '92, Jeshi la Mzee and Mungiki. War veterans, recruiting unemployed urban youth, and later the youth trained through the National Youth Service programme, were active in Zimbabwe. However, the relationships between the ruling party and these private armies have not been easy. These groups became pivotal in the campaigning and their loyalty had to be rewarded. On the other hand, by becoming pivotal they also posed a threat to the established power structures in the ruling parties. In the long run deploying private militia is not a sustainable method of winning the political competition (elections after elections) and running the government. And indeed, in Zimbabwe in the Operation 
Figure 4. Contested electoral procedure

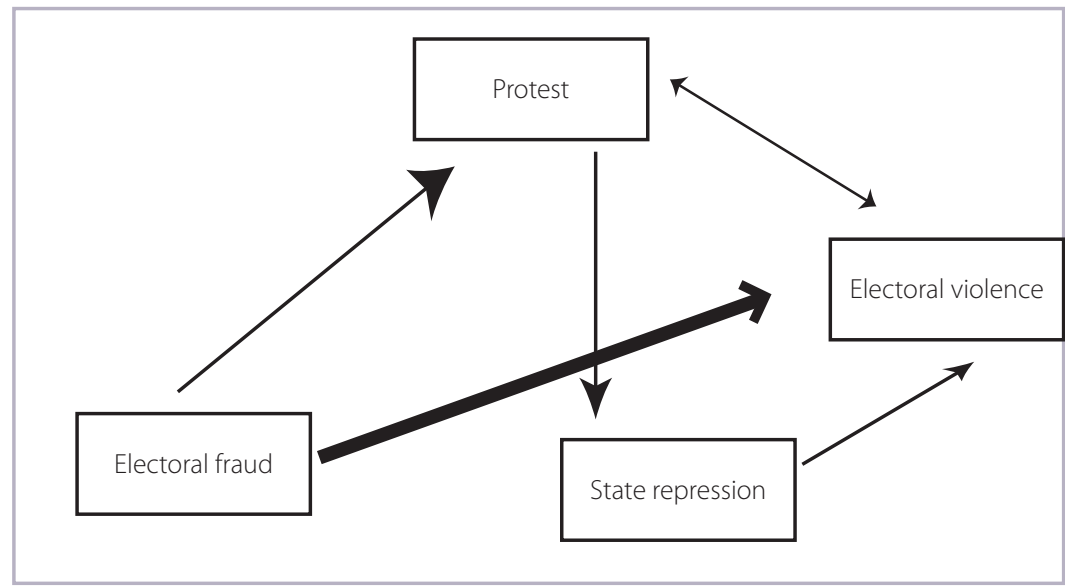

Murambatsvina conducted by the government forces both opposition supporters and war veterans were victimised.

The possibility to hire and mobilize unemployed youth for the private armies was important and related to the economic crisis in Kenya and Zimbabwe (Figure 3). All parties had to pay attention to youth mobilization simply because they played such a visible role in the pressure for change. In the early 1990s, youth mobilization in the Kenyan urban centres had been pivotal to the strengthening opposition and to demands for political freedoms. In Zimbabwe, a majority of the youth, especially the educated youth, supported the MDC. But there were also youth who were hired and trained for the war veterans' militia.

Zanzibar, in turn, presents a case where new liberties offered the opposition an opportunity to mobilize but the election process was managed in favour of the ruling party. After the elections the protest by the opposition led to violent clashes (Figure 4).

Electoral fraud was not absent from the Zimbabwean elections either. In Zimbabwe it took the form of disenfranchising potential opposition supporters by various methods. The mere fact that the methods were more sophisticated than the chaos in the counting in Zanzibar, reflects the long experience of multiparty elections in Zimbabwe. The electoral authorities had skills to manipulate the elections. The fraud, however, did not go unnoticed by the opposition, which has at least as good expertise on the elec- 
toral process as the government. The opposition took the irregularities to the courts, which had actually become a common practice in Zimbabwean elections since the mid 1990s.

On the part of the opposition parties, legal strategies to fight against electoral fraud as well as the political strategies to provide peaceful channels to the youth to express their dissatisfaction point to important developments in all the cases presented in this chapter, namely to the strengthening of the normative framework of the elections.

If the elections are to be meaningful, competition must of necessity be enthusiastic in the African context of economic crisis where also state power, not only the decision-making system or the legitimacy of the leaders, is contested. In the short run, it might well be that neither the economic crisis that contributes to electoral competition, nor fraud as part of the competition can be eliminated from multiparty political competition. But they can be dealt with in peaceful ways in spite of, or rather with the help of, multiparty politics. All players can learn: opposition, civil society, but authoritarian leaders as well. Kenya in 2002 suggests such a development. Multiparty electoral competition is by nature not peaceful. It has to be made peaceful. In achieving this, independent electoral commissions, careful design of the electoral system and monitoring of the situation even after the elections can be helpful.

\section{References}

Addison, T. and L. Laakso (2003), 'The Political Economy of Zimbabwe's Descent into Conflict', Journal of International Development 4: 15, pp. 457-470.

Auvinen, J.Y. (1996), 'IMF Intervention and Political Protest in the Third World: A Conventional Wisdom Refined', Third World Quarterly 17: 3, pp. 377-400.

Bakari, M.A. (2001), The Democratisation Process in Zanzibar: A Retarded Transition, Hamburg African Studies 11.

Bakari, Mohammed A. (2002), 'Democratization And Political Settlement in Zanzibar', Presented at a Symposium on Democratization and Conflict Management in Eastern Africa held at the Centre for Africa Studies, Göteborg University, 28 February-3 March 2002.

Burgess, T. (1999), 'Remembering Youth: Generation in Revolutionary Zanzibar', Africa Today 46: 2, pp. 29-50.

Cameron, G. (2002), 'Zanzibar's Turbulent Transition', Review of African Political Economy 92, pp. 313-330.

Cameron, G. (2004), 'Political Violence, Ethnicity and the Agrarian Question in Zanzibar,' in Pat Caplan and Farouk Topan (eds), Swahili Modernities Culture, 
Politics and Identity on the East Coast of Africa, Trenton, NJ: Africa World Press, pp. 102-119.

CCM and CUF (1999), Agreed Memorandum Between Chama Cha Mapinduzi (CCM) and The Civic United Front (CUF), Dar es Salaam, 29 April 1999.

Chachage, C. and L. Seithy (1998), Land, Forests and People in Finnish Aid in Tanzania, Some Preliminary Observations, FAD Working Paper 2/98, Institute of Development Studies, University of Helsinki \& Department of Sociology, University of Dar es Salaam.

Collier, P. and A. Hoeffler (1998), On Economic Causes of Civil War. Washington: World Bank.

Cowen, M. and M. Ngunyi (1997), Preludes to the 1992 and 1997 Election in Kenya: Reconciling Reform Within a Chain of Events, Working Paper 10/97, Institute of Development Studies, University of Helsinki.

Cowen, M. and K. Kanyinga (2002), 'The 1997 Elections in Kenya: The Politics of Communality and Locality' in Cowen, M. and L. Laakso (eds) Multi-party Elections in Africa. Oxford: James Currey, pp. 128-171.

Eckstein, H. and T.R. Gurr (1975), Patterns of Authority: A Structural Basis for Political Inquiry. New York: Wiley.

Ellingsen, T. and N.P. Gleditsch, (1997), 'Democracy and Conflict in the Third World', in Volden, K. and D. Smith (eds) Causes of Conflict in the Third World Countries. Oslo: PRIO and North/South Coalition, pp. 69-81.

EUEOM (European Union Election Observation Mission) (2002), Kenya General Elections, 27 December 2002, Final Report.

FIDH (La Federation Internationale des Ligues de Droits de L'Homme) (1997), An Unlevel Playing Field: FIDH Report on Mission to Kenya 22nd September-1st October 1997, Report No 250/2, November 1997.

Freedom House (2005), Freedom in the World 2005, The Annual Survey of Political Rights and Civil Liberties [http://www.freedomhouse.org/].

Gleditsch, K.S. and M.D. Ward (2000), 'Peace and War in Time and Space: The Role of Democratization', International Studies Quarterly, 44: 1, p. 29.

Good, K. (2002), 'Dealing with Despotism: The People and the Presidents' in Melber H. (ed.) Zimbabwe's Presidential Elections 2002: Evidence, Lessons and Implications, Discussion Paper 14. Uppsala: Nordiska Afrikainstitutet, pp. 7-30.

GOZ (Government of Zanzibar) (2003), Zanzibar Country Analysis, Final Report, the Economic Research Bureau of the University of Dar es Salaam, April 2003, http://www.tzdac.or.tz/Znz/Country\%20Analysis.doc .

Gurr, T.R. (1970), Why Men Rebel. Princeton: Princeton University Press.

Gurr, T.R. and R. Duvall (1973), 'Civil Conflict in the 1960s', Comparative Political Studies 6, pp.135-170.

Hirschler, K. (2001), 'Sansibar - Krise und (k)ein Ende. Kann ein Abkommen mit der Opposition den politischen Stillstand beenden?', Afrika Spectrum 36: 3, pp. 319-346. 
Holmquist, F. (2002), Business and Politics in Kenya in the 1990s, Occasional Paper, Centre of African Studies, University of Copenhagen, July 2002.

HRW (Human Rights Watch) (1993), Divide and Rule: State-Sponsored Ethnic Violence in Kenya. New York: HRW.

HRW (2002), The Bullets Were Raining - The January 2001 Attack on Peaceful Demonstrators in Zanzibar. April 2002.

Huntington, S.P. (1968), Political Order in Changing Societies. New Haven: Yale University Press.

IMF (2003), Tanzania: Selected Issues and Statistical Appendix, Country Report 03/2, 7 January 2003.

Johnson, R.W. (2000), Political Opinion in Zimbabwe 2000. Johannesburg: Helen Suzman Foundation.

K'Amolo, J. (2003), 'Mungiki: A Mysterious Sect, a Thorn in the Flesh', African Church Information Service, Nairobi, 3 February 2003.

Kenya (2000), Second Report on Poverty in Kenya, Vol. 1. Incidence and Depth of Poverty. Nairobi: Ministry of Finance and Planning.

KHRC (Kenya Human Rights Commission) (1998) Kayas of Deprivation, Kayas of Blood: Violence, Ethnicity and the State in Coastal Kenya. Nairobi: KHRC.

KHRC (1997), Quarterly Repression Reports, April-June 1997.

Kivimäki, T. and L. Laakso, (2003), 'Agents, motives and instruments of African conflicts', International Journal of Development Issues 1: 2, pp. 17-44.

Klopp, J. (2001), 'Ethnic Clashes and Winning Elections: The Case of Kenya's Electoral Despotism', Canadian Journal of African Studies 35: 2, pp. 473-517.

Kriger, N. (2005), 'ZANU(PF) strategies in general elections, 1980-2000: Discourse and coercion', African Affairs 104, pp. 1-34.

Kumar, K. (ed.) (1998), Postconflict Elections, Democratization \& International Assistance. Boulder: Lynne Rienner.

Kuria, G.K. (1994), Majimboism, Ethnic Cleansing and Constitutionalism in Kenya. Nairobi: KHRC.

Laakso, L. (2002), 'The Politics of International Election Observation: The Case of Zimbabwe in 2000', Journal of Modern African Studies 40: 3, pp. 437-464.

Laakso, L. (2003), 'Opposition Politics in Independent Zimbabwe', African Studies Quarterly 7: 2, http://www.africa.ufl.edu/asq/.

Lichbach, M.I. (1989), 'An Evaluation of "Does Economic Inequality Breed Political Conflict?”Studies', World Politics 41: 4, pp. 431-470.

Lindberg, S.I. (2004), 'The Democratic Qualities of Competitive Elections: Participation, Competition and Legitimacy in Africa', Commonwealth and Comparative Politics 42: 1, pp. 61-105.

Mehler, A. (2003), Politische Parteien und Gewalt in Afrika. Systematische Überlegungen vor empirischem Hintergrund, University of Leipzig Papers on Africa 64.

Mkandawire, T. (2002), 'The Terrible Toll of Post-Colonial "Rebel Movements" in Africa: Toward an Explanation of the Violence Against the Peasantry', Journal of Modern African Studies 40: 2, pp. 181-215. 
Moyo, S. (2000), Land Reform under Structural Adjustment in Zimbabwe: Land Use Change in Mashonaland Provinces. Uppsala: Nordiska Afrikainstitutet.

Muller, E. and M.A. Seligson (1987) 'Inequality and Insurgency', American Political Science Review 82: 2, pp. 425-451.

Muller, E.N. and E. Weede (1990) 'Cross-national variation in political action approach', Journal of Conflict Resolution 34: 4, pp. 624-651.

Przeworski, A. (1991) Democracy and the Market, Political and Economic Reforms in Eastern Europe and Latin America. Cambridge: Cambridge University Press.

Quantin, P. (1998) 'Pour une analyse comparative des élections africaines', Politique Africaine 69, pp. 13-26.

Reilly, B. and A. Reynolds (1999) Electoral Systems and Conflict in Divided Societies, Papers on International Conflict Resolution, National Academy Press.

Reychler, L. (1999) Democratic Peace-Building and Conflict Prevention: The devil is in the transition. Leuven: Leuven University Press.

Sheriff, A. (2001) 'Race and Class in the Politics of Zanzibar', Afrika Spectrum 36: 3, pp. 301-318.

Sen, A. (1976) 'Poverty: An ordinal approach to measurement', Econometrica 44, pp. 219-231.

Transparency International (2005) Global Corruption Report 2005. Berlin, http://www. globalcorruptionreport.org/.

UN (2005) "Report of the Fact-Finding Mission to Zimbabwe to assess the Scope and Impact of Operation Murambatsvina”, by Anna Tibaijuka, the UN Special Envoy on Human Settlements Issues in Zimbabwe, http://www.unhabitat. org/documents/ZimbabweReport.pdf .

UNDP (1999), Kenya human development report. 1999. Nairobi: UNDP.

UNDP (2002), Human Development Report 2002: Deepening Democracy in a Fragmented World. Oxford: Oxford University Press.

Zanzibar (2002), Zanzibar Poverty Reduction Plan (ZPRP), Macroeconomic Framework, Background Paper. Zanzibar Revolutionary Government, April 2002.

Zimbabwe Human Rights NGO Forum (2002), Pre-Election Danger Signals of LargeScale Disenfranchisement Zimbabwe. Human Rights NGO Forum, Research Unit Briefing Paper 1. 


\section{Banknotes and Symbolic Capital \\ Ghana's Elections Under the Fourth Republic}

Paul Nugent

During the 1990s, when electoral democracy underwent a renewed lease of life in Africa after decades of one-party and military rule, there were nevertheless as many disputed results as there were clearcut victories. ${ }^{2}$ In the furore which often ensued, the complainants typically invoked one or more of the following grounds for withholding their acceptance of the official figures: that the electoral commissions in question were politically biased; that the voters rolls were artificially inflated or otherwise massaged; that ballot boxes and papers had been tampered with; that violence and intimidation had been resorted to; and finally that the winning side had engaged in straightforward vote-buying. Whereas the other allegations amounted to a denial that the voting figures were an accurate reflection of what had actually occurred on polling day, the claims about harassment and vote-buying sought to explain why voters had not apparently pursued their best interests - either by abstaining or voting the governing party out of power. In most African countries, the incumbents certainly enjoyed an enormous advantage by virtue of their control of the financial purse-strings. This enabled them to offer voters certain material inducements in return for their compliance on polling day. Be that as it may, vote-buying was always a secondbest strategy. It was much more effective, as well as considerably cheaper, to strangle the opposition in so many other ways than to make promises which might seem unlikely to be fulfilled - a point well understood by an arch-Machiavellian like Gnassingbe Eyadéma in Togo. Allegations about wholesale vote-buying therefore need to be taken with a pinch of salt, given that most African regimes have lacked the means to reward compliance, whereas punishing dissent is a rather more straightforward affair.

1. The author would like to acknowledge the receipt of financial assistance from the Nuffield Foundation which enabled him to carry out research on the Ghanaian elections in 1992 (award SOC/100 [227]), 1996 (SOC/100/[1369]) and again in 2000 (SGS/00491/G).

2. For an analysis of the entire decade, see Nugent (2004), ch. 9. 
In this paper, I explore the importance of money in Ghanaian elections since the start of the Fourth Republic in 2002. For those who are interested in comparative democratization, the Ghanaian scene appears instantly recognizable. There are well-established political parties (as well as many which have briefly flickered and died) which field candidates, which publish glossy manifestos and increasingly project slick media images around election time, and which are kept ticking over by a hierarchy of party officials in between the bursts of frenetic activity. The present political system is also readily comprehensible as a hybrid between a presidential and a firstpast-the post parliamentary system, based on single-member constituencies, in which the National Electoral Commission (NEC) holds the ring. Despite lingering controversy surrounding the 1992 polls, and allegations of under-age and multiple voting in subsequent elections, the broad consensus is that this is an electoral system which functions pretty well. ${ }^{1}$ An underlying sense of confidence in the process is underlined by the fact that Ghanaians have turned out in large numbers to cast their ballots, most recently in a string of by-elections, and that the losing sides in 1996 and 2000 accepted their defeat with relatively good grace. There is, therefore, some reason to believe that electoral democracy is on the way to becoming institutionalized.

In this paper, however, I am less concerned with formal institutions than with the inner workings of politics in Ghana. At election time, the politicians and the voters are locked in their own coded exchanges which bring factors into play which would never feature in a party manifesto. This is particularly the case at the constituency level where politics frequently has a dynamic all of its own (Ayee, undated; Ayee, 2001). ${ }^{2}$ Although I will seek to demonstrate that the voting patterns of the recent past are highly significant, I want to convey something of the currency in which Ghanaian politics is transacted. I use this metaphor advisedly, to refer to the ways in which politicians are constantly seeking to convert a range of resources into votes. Although much of the debate in Ghana has centred on money, and especially the unfair advantages which accrue to those who control state power, it is important to recognize that this is one kind of resource amongst several. Money cannot literally buy votes under conditions of a

1. On the question of whether the 1992 presidential election was rigged, see Nugent (1995: 233-237). Some questions are raised about the 2000 polls, in respect of the Volta and Ashanti Regions, in Smith (2002: 633-638).

2. We are fortunate in having a rich collection of constituency studies for 1996 and 2000 which we mostly lack for earlier periods. 
secret ballot: at best it can buy goodwill. In other words, banknotes need to be converted into some kind of moral authority, which is weighed in the scales against other (non-material) claims to the exercise of leadership. As anthropologists remind us, the manner in which wealth is acquired and expended is also susceptible to interpretation in decidedly anti-social terms (Geschiere 1997). ${ }^{1}$ Politicians have to be careful about their public images because there is often a fine line between public adulation and disapprobation. It is the furious wheeling and dealing in these currencies which explains the fascination that politics holds for Ghanaians. We begin the paper with some general observations about electoral politics in Africa, before turning to the Ghanaian evidence in more detail.

\section{Converting currencies: Material resources and symbolic capital}

In most African countries where there has been a meaningful movement towards multi-partyism, one could be forgiven for thinking elections are an extension of the market-place. Although the state has supposedly shrunk, and resources are as likely to be channelled through alternative circuits such as NGOs, it remains the most important show in town. There is equally an insatiable demand for expenditure on basic social services such as health, education and water supplies - which communities only have a limited capacity to sustain by their own efforts - as well as for roads and electricity which are well beyond their capacities. Politics therefore turns very directly on the question of who gets what levels of access to all-too-finite resources. The public typically trades votes in return for more or less concrete pledges of expenditure. Because the financial tank is always running on empty, and the terms of Structural Adjustment agreements limit the scope for significant increases in public borrowing, the victors are almost bound to disappoint their constituents. Indeed, one might say that this a greater threat to the viability of electoral democracy in Africa than rigging is. The enthusiasm which surrounded the first elections after decades of one-party and/or military rule is likely to dissipate by the time it comes to the third or fourth turn of the wheel. Nevertheless, precisely because elections do matter in material terms, many are likely to continue turning out on the 'better luck next time' principle.

1. I refer here to the literature on the association between the accumulation of wealth and the practice of witchcraft. 
Issues of money also tend to dominate the entire process of campaigning. Contesting elections is an expensive business for all concerned, and the deposits which need to be lodged with the electoral commission are usually enough in themselves to exclude most people from running for office above the local government level. Where central funding for political parties was introduced in the 1990s, it tended to be with the Machiavellian intention of sponsoring a proliferation of small opposition parties who would pose less of a threat to the ruling party. Such was the case in Gabon, where Omar Bongo was able to fragment the opposition forces through this stratagem (Messone and Gros 1998: 141). In most countries, however, political parties have had to come up with all of their own finances, which places the opposition in a 'Catch 22' situation. Unless they are already poised to take power, they are unlikely to attract substantial donations, but in order to reach that point they need enough money to establish a national presence. African political parties do not normally have the wherewithal to do more than fund the presidential candidate, leaving the would-be legislators to fend for themselves. Hence it is only the relatively wealthy sections of society who can normally afford to participate, which explains why businessmen and lawyers tend to predominate. The humble school teacher, who often predominated in the African legislatures of the immediate post-independence period, is unlikely to be able to stand unless he/she has a wealthy patron waiting in the wings.

The legislative candidates are likely to earn their money in the cities, which means that in their dealings with rural voters they will not only seem vastly richer than those they are seeking to win over, but will also need to work hard to establish their local credentials. In the urban areas - which now contain the numerical majority in countries like the Republic of Congo (Congo-Brazzaville) - a politician resident in the more salubrious suburbs will face a similar difficulty in relation to voters in the poorer quarters. As many a candidate in many an African country will attest to, voters expect to be showered with gifts as evidence that the candidate genuinely does have local interests at heart. These acts of benevolence may be more or less formalized. In Kenya, it has long been the practice for politicians to contribute to harambee projects from their own pockets as well as calling in favours from allies and patrons (Throup 1987; Widner 1992; Haugerud 1995). Indeed, the entire Kenya political system since independence has rested on the exchange of material resources for political support, with competition for office during the era of the one-party state being every bit as cut-throat as under conditions of multi-partyism. Elsewhere, the dynamic 
is more fluid, but across Africa the politician who fails to demonstrate an appropriate measure of generosity is likely to be castigated as selfish and to be punished on polling day.

When politicians do distribute largesse, it is a moot point whether one should regard this as a purely material exchange. Being cynical, one might argue that elections are the one time when ordinary people get a chance to 'chop' at the expense of their social superiors, and not surprisingly they revel in the moment. In Ghana, villagers have made a habit of accumulating tee-shirts from all the parties which happen to pass through. Although they might wear the shirt bearing the image of their favoured party while walking about in town, the rest come in handy as clothing with which to go to farm. In my experience, rural voters positively relish the chance to turn the tables on gullible politicians who imagine that expressions of interest signal a genuine intention to vote for them. On one reading, such exchanges are indeed about material inducements. However, there are clearly social logics in operation as well. As already suggested, a candidate who has been absent in the city for long stretches of time may need to (re-)establish a social bond with his/her rural community - in a sense, to demonstrate the sociability of wealth acquired elsewhere. In many African countries, from Cameroon to Kenya, the accumulation and the exhibition of wealth are invested with overwhelmingly positive attributes. However, wealth is also associated with moral compromises - through outright corruption or neglecting rural kin in favour of the nuclear family in town - and at worst with activities which are construed as socially destructive, such as the occult. Because money is socially ambiguous, it can only be 'cleansed' - one is tempted to say 'laundered' - by being filtered through social networks. Viewed in these terms, the distribution of banknotes or bags of rice goes far beyond being a purely material exchange. It demonstrates that the politician does recognize his/her local responsibilities.

Of course, elections are never fought purely on the terrain of inducements. Voters are courted on the basis of appeals to the head and the heart as much as to the belly. Where ethnic and religious cleavages are obvious, candidates may draw votes on the basis of being a part of 'us' rather than 'them'. Although there has been a greater level of cross-ethnic voting in Nigeria than is often appreciated, this is undoubtedly a feature of politics in that country, and it has rapidly become the norm in Côte d'Ivoire. Conversely, where there is a dominant consensus, parties may struggle over the claim to being the guarantors of a great tradition. In Sénégal, Leopold Senghor and Abdou Diouf felt able to tolerate opposition parties, at a time 
when one-party states were the continental norm, because they were confident of their special relationship with the grands marabouts which had been forged in the struggles for power before and immediately after independence. ${ }^{1}$ The politicians of the Parti Socialiste (PS) went out of their way to curry favour with the brotherhoods, and although there certainly was a material dimension to the sweetheart relationship with the Mourides, the ruling party attempted to prove that it genuinely venerated religious authority (Boone 1992: 108). ${ }^{2}$ Where political traditions are well-entrenched, parties may also be associated with particular agendas: such as being either favourable to chiefs or hostile to them, or being a party of the countryside as opposed to the city. Where everyone knows their history, it may not be necessary for politicians to belabour their message. A reference in passing to this or that person or event may be enough to signal to voters why they ought to support one side rather than another. Although party colours and symbols can be pretty arbitrary, these may also be loaded with a deeper significance which is not lost on voters.

The fact that politicians can invoke other bonds of emotional solidarity might appear to take some of the pressure off empty pockets. But if, as John Lonsdale maintains, ethnicity (to take one variable) involves an internal debate about the terms of civic virtue as much as opposition to other groups, then there is also likely to be pressure upon politicians to demonstrate their caring side (Lonsdale 1992). At a more basic level, symbolic capital is likely to remain idle unless politicians can raise the money to mount a campaign in the first place. Cash-strapped politicians typically seek to tap the resources of wealthier individuals, appealing to the solidarities which supposedly bind them together. If wealth needs to be socialized, therefore, there is also a sense in which social ties tend to be valorised. The currencies are constantly being traded back and forth as politicians, 'big men' and constituents negotiate the detailed terms of their relationship. In the process of striving for the right mix, there are inevitably failures as well as success stories. Probably every country has its version of the hapless politician who is generally reckoned to be well-intentioned and is even regarded with some affection, but is destined to remain one of life's losers because of his/her

1. The rift between Senghor and Mamadou Dia in 1962 was caused in large part by the marabouts who were concerned about competition for the loyalties of the peasantry. See Schumaker (1975: 63-67).

2. The marabouts benefited materially from the arrangement which was subsequently reached, and in return called on their talibés to vote for the ruling party. There was, however, some tension between the two according to Villalón (1995: 219-222). 
inability to attract enough financial backing. Equally, each country has its story of the 'money bags' who mistakenly assumed that people would vote for him purely on the basis that he was fabulously rich. One might conclude that in these cases the individuals concerned have failed to put together a balanced portfolio. Thus far, the discussion has been conducted at a rather abstract level. I turn now to consider the inner workings of politics in Ghana since the return to multi-partyism in 1992.

\section{The Business of politics and the politics of business in contemporary Ghana}

Although much of what has been said can be applied directly to Ghana, there are also some particular variations in the way politics is transacted in that country. A striking characteristic which has frequently been commented upon by academic observers and political actors alike is the depth of allegiance to discrete political traditions. If we discount the smaller parties which have failed to win any representation in parliament, there are four parties which dominate the political scene today: the National Democratic Congress (NDC), which was in office between 1992 and 2000; the New Patriotic Party (NPP) which finally broke through in the latter elections; the Convention People's Party (CPP) and the People's National Convention (PNC). Both the CPP and the PNC claim to be a modern reincarnation of Nkrumah's CPP which was founded in 1949 and was the dominant force until it was overthrown by a military coup in 1966 . The dispute between them arises from a difference of opinion as to whether Dr Hilla Limann, the President of a People's National Party (PNP) administration between 1979 and 1981, was the sole heir to the Nkrumahist inheritance. Despite his passing from the scene, the PNC (which he founded) has refused to subsume itself within the CPP and has added a northern accent to Nkrumahism. The NPP claims an equally illustrious lineage, stretching from the United Gold Coast Convention (UGCC) in the mid-1940s, through the United Party (UP) in the 1950s to the Progress Party (PP) in the 1960s and the Popular Front Party (PFP) between 1979 and 1982. The NDC has a rather shorter history, being rooted in the 'Rawlings revolution' of the early 1980s and the populist agenda of the Provisional National Defence Council (PNDC). However, the NDC has endeavoured to establish itself as the third force in Ghanaian politics.

As in many African countries, there is little real ideological contestation either over the configuration of the state or over social issues. All of the ma- 
jor parties accept that there is no going back on Structural Adjustment, and hence the reality is that there is a limit to what the state can do in terms of creating urban jobs, subsidizing agricultural inputs or providing free health and education - despite the popularity which would accrue to any government which went down any or all of those routes. They all concede that the revenues to fund better social services, and the economic dynamism needed to expand employment, will have to come primarily from the private sector, and they all place their faith in greater inward foreign investment. They do differ on points of detail, such as whether fuel prices or VAT should be higher or lower, but the debate mostly turns on who is likely to manage the existing dispensation more efficiently. But if there is no sharp ideological divide, there are certainly longstanding differences of political style. In the minds of voters, the parties have come to symbolize different things. The CPP in its earlier incarnation stood for the 'young men' or commoners against the chiefs and the urban elite. It also stood for rapid economic modernization based on purposeful state intervention. Although rampant statism is no longer regarded as a serious option, the CPP and the PNC still claim to speak for the common man and constantly return to what ought to be done to alleviate the pains of adjustment. The Busia/Danquah tradition, which the NPP claims to uphold, has traditionally been associated with a highly patrician style of leadership. It has been dominated by certain political families - one might even say dynasties - from the Ashanti and Eastern Regions with a foot in business or the professions, especially law. It claims to have consistently championed the virtues of private enterprise and the rule-of-law, even if the constitutionalism of many of Kofi Busia's acts as Prime Minister was highly questionable.

The NDC is above all associated with the populist leadership style of Flt.-Lt. Jerry Rawlings who poured scorn on the political class for being more interested in feathering its own nest than in bettering the lot of the average Ghanaian. Rawlings' supporters claim that he has a unique empathy with the ordinary people, and it is certainly true that he can still draw a bigger crowd than anyone else in Ghana to this day. What his detractors deride as irresponsible buffoonery often goes down rather well as the kind of plain-speaking for which politicians are not normally noted. The NDC was originally founded as a vehicle for the presidential ambitions of Rawlings, but he has always had a rather semi-detached relationship to party structures. ${ }^{1}$ The NDC has claimed to stand for the betterment of the living

1. Ironically, he has displayed a greater level of interest in the party since going into retirement in 2000. 
standards of ordinary Ghanaians and to have done its utmost to address the needs of the rural majority, especially in the more deprived regions. It has often infuriated Nkrumahists and NPP alike by freely borrowing from both of their scripts. As the initiator of Structural Adjustment, the PNDC/NDC has commonly expressed itself in the language of economic liberalism, while the populist rhetoric of Rawlings has drawn from the Nkrumahist repertoire. Indeed since 1992, the NDC has sought to corner the Nkrumah legacy for itself, despite the contemptuous terms in which Rawlings had previously referred to the first President. ${ }^{1}$

Particular areas of the country have a history of backing one tradition rather than another, and it is this which politicians seek to manipulate to their advantage. On home turf, they will seek to exploit local preconceptions. On the campaign trail, a few choice words may have greater force than the most carefully constructed speech. A reference to Nkrumah's special treatment of northerners in matters of education is likely to resonate favourably in the Upper East, Upper West and the Northern Regions; in Ashanti a few Twi proverbs about birth and belonging is likely to elicit knowing smiles; while in the Volta Region an NDC politician only needs to utter the name 'Victor Owusu' for memories of past insults to come flooding back. ${ }^{2}$ Ghanaian campaign rallies can drag on for hours - such is the concern that each person in the pecking order should have his chance to speak - but a bored audience can be brought to instant attention by means of a witty or scurrilous allusion. For politicians seeking to reverse the habits of a political lifetime, the task is likely to be a more difficult one. However, the contention that constituents have been taken for granted by the opposing side, and that it is time to try out the alternatives, is one which has often been made. Because certain parts of the country have swung from one tradition to the other, they tend to be regarded as the key battlegrounds in national elections.

1. Nkrumah has ascended to the head of the national pantheon and his memory far surpasses that of his rivals, including both Dr. J.B. Danquah and Kofi Busia. The construction of the Nkrumah memorial in Accra in 1992 was the most visible indication of the NDC's determination to use the Nkrumah name for is own purposes.

2. The educational backwardness of the former Northern Territories was taken up by Nkrumah who introduced special privileges to enable northerners to attend university. The non-Ghanaian origins of Rawlings' father is something which has often been used against him in a society fixated by kinship ties. Finally, Owusu's description of Ewes as 'inward looking' has never been forgotten or forgiven east of the Volta and is still used against the NPP today. 
The two main contenders for office in recent elections, the NDC and the NPP, have also made use of competing discourses of marginality which have shifted subtly over time. The NDC has accused the NPP of being elitist whilst claiming to more accurately reflect the makeup of Ghanaian society. There is a certain truth underlying what is otherwise a crude stereotype. The NPP leadership does contain some members of the dynasties alluded to above, such as Nana Akuffo-Addo (the present Foreign Minister), and is distinguished by its impressive level of educational attainment. The NDC, on the other hand, has been headed by people from more humble social origins and with a more modest educational profile: certainly a Ph.D. is a rare commodity. ${ }^{1}$ Many of the NDC members of parliament (MPs) came into politics through the institutions associated with the PNDC, either as PNDC Secretaries or as members of the Committees for the Defence of the Revolution (CDRs). Their backgrounds typically lie within the teaching profession, the civil service and the military rather than the professions. In parliament, the NDC has struggled to match the more polished and articulate NPP spokesmen in debate, such has been its failure, or unwillingness, to attract members of the intelligentsia. However, this has also played to the populist self-image of the party.

The NPP, of course, denies that it was ever elitist in character. However, it is undoubtedly proud of the calibre of its front-bench, which is in line with a history of placing great store by personal achievement going back to the days of the UGCC. Prior to its historic victory in 2000, the NPP appealed to voters on the basis that it possessed all the technocratic skills needed to solve the economic and social problems of the country. The apparent affluence of many NPP leaders was even turned to its advantage: that is, it was argued that whereas the NDC was made up of 'ne'er do wells' who expected to profit from holding high office, the NPP team was comprised of high-flyers who were rich enough to resist the allure of corruption, and who were indeed in a position to put something back into the collective pot.

Related to this clash of representations is a dispute about who 'the masses' really are. As noted above, the NDC has set itself up as the spokesman for the virtuous rural majority in neglected corners of the country. In the past, the Busia/Danquah tradition had positioned itself as a party with strong rural roots - especially in Ashanti, Brong-Ahafo and the Eastern

1. The obvious exception is Dr Obed Asamoah, the godfather of the party, who to some extent lords it over the rest of the leadership because he does possess a much higher level of education. 
Region - whereas it had always performed rather poorly in the cities, where the Nkrumahist message went down rather better. However, over the past decade the NPP has re-invented itself as a party of the cities - at a time when the modern CPP has conspicuously failed - whilst seeking to hang on to its former support-base. Although we still await the data from the last census, the changing shape of Accra and Kumasi strongly suggests that the pace of urbanization has accelerated since the early 1980s. Over the following decade, the cities came to represent a real headache for the NDC because of its inability to generate employment and because social problems tended to accumulate there. Moreover, the urban population has had access to a much wider range of political information, especially commentary from the private press which ruthlessly exploited every government embarrassment. The NPP made significant inroads into the urban areas in 1996 by exploiting a growing sense of malaise in the cities (Nugent 1999). In the run-up to the 2000 elections, the NPP took this a step further by targeting urban youth as its core constituency - much as the Parti Démocratique Sénégalais (PDS) did with similar success in Sénégal. This transformation in the image of the NPP - from the party of the patricians to a party which is at home with the plebeians - represents perhaps the most significant shift in Ghanaian politics in recent times. Surprisingly, this has attracted relatively little academic comment. Perhaps the insight about the cyclical nature of Ghanaian politics has blinded commentators to the possibility of seismic shifts in the political sub-structure.

At this point in the discussion, let us turn to consider the role of money in greater detail. Elections in Ghana have proven to be an expensive business for everyone concerned. Presidential aspirants have needed to spend liberally in order to secure the party nomination in the first place. Then, in the run-up to the polls, there is roughly a year of solid campaigning to be done, involving visits to constituencies up and down the country, in which it is sound practice to make 'voluntary contributions' to one good cause or another. Finally, during the campaign itself the candidates have to visit all the nooks and crannies, accompanied by a large entourage of retainers who have to be housed, fed and transported. The candidates usually 'greet' the chiefs at every port of call, which typically involves the purchase of schnapps and the presentation of gifts which, however token, certainly add up. Then there is the need to invest heavily in billboard and media advertising and to print large numbers of tee-shirts and posters which are visible in virtually every town and village across the country. Allegedly, it has also been necessary for the opposition to make payments to individuals within 
the Ghana Broadcasting Corporation (GBC) in order to secure television coverage of mass rallies where visible evidence of numbers is crucial to demonstrating that a particular campaign has achieved lift-off. At the constituency level, candidates need to pay the living expenses of party workers, to keep a vehicle on the road and to print their own publicity material. Although there are many who believe that central funding of parties would be a sound innovation, there has been no progress in this direction (BoafoArthur, undated). On the other side, the Constitution and the Political Parties Law (PNDCL 281) of 1992 place limitations upon who may donate money to a political party and up to what level. Not surprisingly, therefore, the perennial complaint of Ghanaian politicians is that they simply do not have enough cash to deliver their message to the electorate. Parliamentary candidates are often literally stuck because they do not even have a vehicle to move about their constituency.

It should come as no surprise to learn that the incumbent party has enjoyed massive advantages over those in opposition. The NDC was able to raise some of its finances from party membership which many urban traders, for example, found it wise to take out. The 31st December Women's Movement (DWM), which was closely tied to the NDC and contributed to party funds, also required women to take out membership before they could qualify for assistance with income-generating projects. Around election time, the NDC also organized special lunches and the like at which members were invited to dip their hands into their pockets. Quite how much was generated through these activities will probably never been known since party finances have been something of a mystery, not least to members of the NDC national executive. The Finance Committee Chairman, Dr. Obed Asamoah, controlled party finances for most of the period in question, and disbursed money in a highly personalized fashion. This came out in 1997 when it transpired that large sums of money were simply stashed in bags in his private house in his home village of Likpe-Bala. ${ }^{1}$ The second source of funding has come from wealthy donors who have contributed in the expectation of receiving favourable consideration in the allocation of government contracts - or at least as an insurance policy against being ruled out of the running. It is known that Construction Pioneers, one of the largest foreign road-contractors, paid money to the NDC in breach of the electoral law, and one imagines that it was not the only one to

1. This came to light when it was revealed that his assistants were helping themselves to the contents. Significantly, Asamoah himself did not have any idea of how much money he was sitting on or how much had been stolen. 
do so. ${ }^{1}$ But so too have many smaller Ghanaian companies which have appreciated the importance of remaining on the right side of the ruling party. The DWM, which claimed to be operating as an NGO, was itself alleged to have been a recipient of substantial donations. When Ghana Rubber Estates Limited (GREL) came up for divestiture, it is alleged that a French firm paid $\$ 550.000$ to the DWM between 1996 and 1998 in an attempt to influence the process in its favour. ${ }^{2}$ Although much of this money was apparently diverted to private ends, this was part of an overall strategy of mobilizing money for political uses. Finally, it was the simplest thing in the world for the ruling party to use state resources for its own ends. One of the most blatant examples is the use of government vehicles to bus people to and from political rallies. Again, at the constituency level the resources of the District Assemblies were placed at the disposal of the NDC. The fact that these assemblies are elected on a non-party basis ironically made it easier for District Chief Executives to behave in a partisan fashion. One consequence of the fact that the NDC did have access to such resources at the constituency level was that it was possible for relatively impecunious candidates to stand for election - which partly accounts for the humble social profile of its MPs.

Even when the incumbent regime has not been diverting state resources, it has been able to manipulate 'development' in such a manner as to achieve the optimal political effect. The NDC famously timed electrification and road-building projects to coincide with the polls, warning voters that they would in all likelihood be terminated if the opposition ever came to power. Interestingly, however, the NDC never played the game of directly rewarding support and punishing recalcitrance. The Volta Region was famously described by Rawlings as the NDC's 'World Bank', such was the dependability of the vote there, but it was never offered any special privileges. Indeed, because the NDC knew the votes were in the 'bank', it may have decided that this was a reason to channel the benefits to other parts of the country. Conversely, the Ashanti Region, was never penalized for voting NPP in 1992 and 1996, and may even have received more than its 'fair share'. The NDC's canny approach was to ensure that enough develop-

1. The firm was subsequently accused of having defrauded the state through tax evasion. Construction Pioneers 'defrauds' government', from the Crusading Guide, 12 December 2002, posted at http://www.ghanaweb.com/ GhanaHomePage/NewsArchive/artikel.php?ID=30237

2. A report from the Daily Graphic, 5 December 2002, posted at http://www. ghanaweb.com/GhanaHomePage/NewsArchive/artikel.php?ID=30237 
ment projects came on stream in every district in the country for it to be considered worth supporting. Although this eventually meant that the government spread itself too thinly, and ended up disappointing much of the electorate, this strategy seemed to work pretty well up until the 2000 polls. It is worth underlining the point that resource allocation in Ghana does not seem to have been politicized to the extent that it has been in Kenya. An elected MP normally has little chance of bringing development projects home by pulling strings in Accra. To a large extent, it is the bureaucracy which has decided where resources should go, subject to the ruling party's determination to ensure as even a spread as possible. The most that MPs have been able to do is to draw on the District Assemblies Common Fund which is theirs to do by right. The NPP has so far continued to operate according to the same logic. While it chided Voltarians for their slavish NDC tendencies, it was quick to deny that rewards would be channelled only to those who voted for it in 2000. Since its victory, the NPP has underlined its willingness to treat NDC areas on a par with its political heartlands with a view to convincing the former that it can in fact be trusted. Consequently, Ghanaian politics lacks the zero-sum quality which has been such a feature of many other countries with finely-tuned patronage systems.

On the opposition side of the equation, the practical difficulties of fighting an election are very considerable. Of course, the opposition parties enjoyed no access to state resources when the NDC was in power, and even though their MPs could call on the Common Funds the District Chief Executives often attempted to thwart their spending plans. The opposition was therefore reduced to pointing to a (lengthening) trail of broken NDC promises. The opposition parties tended to attract many more sympathisers than card-carrying members. Moreover, while benefactors might look favourably on an opposition victory, they proved understandably reluctant to sink their money into what was potentially a bottomless pit. The CPP has never managed to escape the 'Catch 22' situation referred to above. It has repeatedly placed its hopes on wealthy saviours who have ultimately failed to come up with the goods, no doubt because the CPP has been losing rather than winning seats in recent times. In 2000, the presidential candidate, Professor George Benneh, was pretty much invisible in the regions, confining himself largely to television appearances which cost relatively little. Following a live television debate in the run-up to the polls, it was generally agreed that the National Reform Party (NRP) candidate, Goosie Tanoh, was by far the most impressive performer. Unfortunately for him, he too lacked the resources to take his message to the country. Although 
this same debate underscored that J.A. Kufuor was less than charismatic or articulate, least of all in English, Ghanaians turned out en masse to hear him as the campaign wore on. The more the NPP looked like it might actually win, the more waverers came off the fence. While continuing to contribute to the NDC, many contractors seemed to have placed a side-bet on the NPP during 2002.

In the constituencies, the plight of opposition candidates has been especially difficult. Even the better-endowed NPP was not able to offer much more than a subsidy for tee-shirts and shared use of a party vehicle in 2000 . Other than that, the most the NPP candidates could hope for was to bathe in the reflected glory of Kufuor as he swung through the constituency. Since 1992, I have been engaged in a long-range study of politics in a single constituency, Hohoe-North, in which I have been able to examine campaigning at close quarters. Here all of the observations about the advantages of incumbency are borne out. In 1996 and 2000, the NDC MP, a retired manager of the Ghana Water and Sewerage Corporation (GWSC), was able to rely on a relatively well-endowed constituency party with at least a couple of vehicles at its disposal at any given time. In 1996, the PNC candidate was a successful road contractor based in Ashanti, whose financial resources attracted a substantial number of party workers. He came second in the parliamentary poll, but when he decided not to stand four years later - allegedly because his business was being jeopardized by his political affiliations - most of these jumped ship. His replacement as candidate was a 'small boy' who nobody really considered electable. ${ }^{1}$ In 1996, the NPP and the People's Convention Party (PCP) candidates were both prominent lawyers in Accra who could afford to channel some of their resources into politics (Nugent 2001b). After burning their respective fingers, neither was tempted to re-enter the race in 2000 , repeating a familiar pattern in the constituency. ${ }^{2}$ The next NPP candidate put up a spirited fight, but lacked the resources to cover the constituency effectively, while the CPP candidate was hardly seen. The NRP candidate had previously been the District Chief Executive before falling out with the NDC over corruption allegations. In interviews and less formal discussions, he was extremely candid about the need to use money to establish one's local credentials, which was

1. These were the words used to describe him by people who had previously worked for the former candidate. The latter apparently began to flirt with the NDC.

2. One of the prominent PCP (and later NRP) activists, who had stood for the People's Heritage Party (PHP) in 1992, once told me that he would not repeat the experience for fear of wrecking his pharmacy business. 
an issue in his case because his family origins lay outside the constituency (in Ada). He referred openly to his purchase of footballs to win over village youth, as well as presents of two bottles of schnapps for the chief and pots of palm-wine for the 'youth' in each community. Far from representing bribery, he insisted that nobody would vote for a candidate who did not demonstrate his/her generosity in this way. ${ }^{1}$ Of course, all of this was very costly and he estimated his own campaign expenses as being in the region of $\$ 10$ million, a figure which seems rather on the high side. ${ }^{2}$ Crucially, however, this candidate understood the social importance underpinning the giving of gifts. Sitting MPs from the NDC have themselves testified to pressures from constituents to play the role of generous benefactors, despite the fact that their salaries are limited. ${ }^{3}$ In the words of one, Edith Haizel: 'You go to them and the approach is a sort of a blackmail. If you can't meet their demands, they tell you the thumb is there. They will definitely not vote for you next time. ${ }^{4}$ The line between deference and hostility is often a thin one, as many politicians have discovered to their cost.

If politics was purely a matter of material resources, then the NDC would still be in the driving seat today, but like the PS in Sénégal its bubble finally burst in 2000 because it could no longer convert money into votes. As I have argued elsewhere, defeat did in fact have something to do with the NDC's self-inflicted financial troubles (Nugent 2001c; Vengroff and Magala 2001). Those who controlled the purse-strings, notably Dr. Asamoah and Mrs. Rawlings (as head of the DWM), reduced the supply of campaign funds when John Atta-Mills was first foisted on the party and then decided to choose a running-mate more to his own liking. Moreover, the government had left many contractors unpaid whilst failing to deliver

1. Discussion with William Puplampu, Hohoe, 12 December 2000.

2. At $\$ 9.500$ to the pound, that would amount to around $£ 1.052$, which is a vast sum. He also claimed that one of the other candidates had estimated his own expenses at $\$ 7$ million. In the Wulensi by-election of March 2003, the NPP denied NDC allegations that it had spent $\$ 10$ billion, but it did admit to spending $\$ 400$ million which is around $£ 30.000$ (at $\$ 13.000=£ 1$ ). "NPP denies spending 10 billion cedis", from Free Press, 7 April 2003, posted at http://www.ghanaweb.com/GhanaHomePage/NewsArchive/artikel.php?ID=35050

3. In April 2003, my sources inform me that an MP earned $\$ 7.163 .566$ before tax and $\$ 5.720 .566,22$ after tax, which is equivalent to $£ 440$ (at $\$ 13.000=£ 1)$. An MP who has taken out a loan on the purchase of a car might take home only $\$ 4.770 .566$

4. "MPs cry out - we are being blackmailed", from Daily Despatch, 9 December 2002, posted at http://www.ghanaweb.com/GhanaHomePage/NewsArchive/artikel. php?ID=30353 
on its many promises up and down the country. On the other hand, the NPP began to pull in greater financial contributions, and is reputed to have received assistance from President Olusegun Obasanjo (via Eyadéma) who bore his own grudge against Rawlings for having fraternized with the Abacha regime. The campaign of 2000 was therefore fought on a more level playing field than before. Nevertheless, the NDC was still relatively welloff by comparison with the opposition parties. The simple reason why the NDC lost its comfortable parliamentary majority and the presidency was that most voters had ceased to trust it. So what had gone so badly wrong?

One reason why the NPP came out on top was that its strategy of targeting areas of support paid dividends. It consolidated its positions of strength in the Ashanti and Eastern Regions, made inroads into the Busia/Danquah heartlands in Brong-Ahafo and made a pitch for the urban youth vote with a vigour which had not been seen before. The injunction to 'Vote for Positive Change' was as deliberately vague as 'Sopi!' was in Sénégal, but it worked in terms of blaming the woes of ordinary Ghanaians on the regime which, it was pointed out, had been in office for far too long. The sense that the NDC had lost the plot was widely shared within the party where there was considerable resentment at the decision to impose parliamentary candidates on the constituencies. It is likely that many natural NDC supporters simply did not turn out to vote in 2000. Secondly, the NDC suffered a progressive disfiguration of its public image. In the days of the PNDC, the leadership claimed to provide youthful and dynamic leadership - and all in the interests of national development. Although the NDC drew in many politicians who had no real link with the PNDC, it was able to trade on this mostly positive image in the early 1990s. However, by the end of the decade the NDC came across as decidedly jaded, and was identified as the very epitome of the 'old order' rather than the thrusting alternative to it. Worse still, the opposition press threw a lot of dirt at NDC politicians, implying that they were all nakedly corrupt, and much of this stuck.

From the perspective of an impartial observer, it has to be said that the standards of public probity declined greatly over the course of the 1990s, while Rawlings himself seemed to lose all interest in how the affairs of the country were being (mis)managed. The fact that he became so close to Abacha, whose looting of the Nigerian treasury made Acheampong seem like a saint, was perhaps the most obvious sign that he had lost his moral bearings. The allegations of malfeasance at the highest levels were widely believed, and shortly after the change of government these were proven in a series of court cases which ended in the jailing of former NDC Min- 
isters. The irony in all of this is that Rawlings had repeatedly expressed his reservations about electoral democracy on the principle that politicians would engage in illegal practices to recoup their electoral expenses. His colleagues demonstrated that it went even deeper than that. Under conditions of economic liberalism, NDC politicians discovered that privatization and deregulation harboured unforeseen possibilities for private accumulation. ${ }^{1}$ Hence yesterday's revolutionaries became today's company directors, while a number of parvenus jumped aboard the gravy-train. If kalabule had been born of the historic conjuncture of state regulation and material scarcity, corruption under the NDC thrived on a new discourse of enterprise. ${ }^{2}$ Consequently, the NPP contention that the NDC was essentially made up of carpet-baggers who had come to office with nothing and had elevated themselves to people of means, rang more than a little true. This was devastating because if the NDC could not persuade Ghanaians that it was at least honest, it had nothing left to offer the public: its economic record since 1992 was less than impressive and the reputation for administrative competence had fallen by the wayside.

The fact that the NDC did not suffer worse indignities at the polls is a consequence of its success in selling aspects of its own discourse of marginality. In the first round of presidential voting, the NPP took the honours in six out of ten regions: Ashanti, Brong-Ahafo, Central, Eastern, Greater Accra and Western Regions. It also swept the cities, winning in every single constituency in Accra, Tema and Kumasi, as well as in most of the regional capitals. In the parliamentary elections, the NPP did not fare quite so well in the Western Region and Central Regions and it narrowly lost one seat in Accra, but otherwise the pattern was repeated. These successes contrast with the signal failure of the other opposition parties whose vote was squeezed by the NPP, posing as the only party which could get rid of the discredited regime. The CPP was reduced to a single seat in parliament, while the PNC managed to increase its share to three seats. Within the NDC, the defeat was considered a catastrophe, albeit one which many had seen looming. In fact, the NDC retained a solid base within parliament (see table), chiefly because it continued to win support from parts of the country which felt themselves to be at the economic and/or cultural margins of national life. The Northern, Upper East, Upper West and most of the Volta Region were

1. For a study which considers a range of African examples, see Tangri (1999) and van de Walle (2001).

2. Ghana is not the only country where this transformation has taken place. Angola is a still more extreme case. See Hodges (2001). 
marginal in both those senses as well as geographically; large parts of the Western Region felt themselves to be economically deprived and to be especially lacking in decent roads; while the non-Akan segments of the Eastern Region and the more rural constituencies of Greater Accra felt somewhat alienated from the perceived Akan axis which the NPP represented $(\mathrm{Nu}-$ gent 2001a). Hence if the NPP could call on the loyalties of the urban poor, the NDC continued to convince peasants in remote villages that it was the most likely to cater to their interests. Despite the best efforts of the NPP to dampen concerns about 'Akan' or 'Ashanti domination', it failed in parts of the country where there was longstanding resistance to the Busia/Danquah tradition.

On the face of things, therefore, the NDC still retained a solid base from which to mount a political comeback. However, since 2000 things have gone from bad to worse for the former ruling party. The continuing stream of revelations about corruption has continued to eat away at the public image of the party. More recently, the creation of a National Reconciliation Commission (NRC) to look into human rights abuses committed under past military regimes has enabled opposition supporters to remind Ghanaians of the less savoury aspects of the Rawlings years. And crucially, the NDC is no longer able to call on the advantages of incumbency which the NPP is (not surprisingly) manipulating to its own advantage. It is not just that the party is cut off from state resources, but many of the people who had provided generous donations in the past would now prefer to keep their distance. Equally, the DWM has been under the spotlight for past abuses and is no longer in a position to channel money to the ailing party. In November 2002, Dr. Joseph Nii Aryeh, the general secretary of the NDC, announced that the party was effectively bankrupt. He even claimed that it lacked the resources to successfully host the conference which was to choose the presidential candidate for 2004. This may have been over-stating the scale of the crisis because his intention seems to have been to discredit Dr. Asamoah who he accused of continuing to operate his own slush funds. Because Asamoah was backing Dr. Kwesi Botchway for the nomination against the express wishes of Rawlings (who campaigned no less openly for Mills) this intervention might have been calculated to damage the chairman. However, Asamoah himself acknowledged that the NDC was bereft of funds. This may well be true, but even if he is still sitting on a stash he might decline to release it in revenge for his humiliating treatment at the party congress, in which Mills was crowned for a second time in a bad-tempered affair. 
Table 1: Seats won by region, 1996 and 2000

\begin{tabular}{lrrrrrrrr}
\hline Region & \multicolumn{2}{c}{ NDC } & \multicolumn{2}{c}{ NPP } & \multicolumn{2}{c}{ PCP/CPP } & \multicolumn{2}{c}{ PNC } \\
& 1996 & 2000 & 1996 & 2000 & 1996 & 2000 & 1996 & 2000 \\
\hline Ashanti & 5 & 2 & 28 & 31 & 0 & 0 & 0 & 0 \\
Brong-Ahafo & 17 & 7 & 4 & 14 & 0 & 0 & 0 & 0 \\
Central & 14 & 9 & 3 & 8 & 0 & 0 & 0 & 0 \\
Eastern & 15 & 8 & 11 & 18 & 0 & 0 & 0 & 0 \\
Greater Accra & 13 & 5 & 9 & 17 & 0 & 0 & 0 & 0 \\
Northern & 18 & 18 & 3 & 3 & 1 & 0 & 1 & 1 \\
Upper East & 12 & 8 & 0 & 2 & 0 & 0 & 0 & 1 \\
Upper West & 8 & 7 & 0 & 0 & 0 & 0 & 0 & 1 \\
Volta & 19 & 17 & 0 & 0 & 0 & 0 & 0 & 0 \\
Western & 12 & 10 & 3 & 8 & 4 & 1 & 0 & 0 \\
Total* & 133 & 91 & 61 & 101 & 5 & 1 & 1 & 3 \\
\hline
\end{tabular}

* There were four former NDC seats which were won by independent candidates, two in the Volta and one each in the Northern and Upper East Regions.

Source: Ghana Gazette, No. 1, 5 January 2001.

The NDC has now lost six by-elections in a row: Kumawu, Bimbilla, Wulensi, Navrongo Central, Gomoa East and Amenfi West. In some cases, the NPP has captured what would previously have been considered safe NDC seats. In Amenfi West, for example, the NDC candidate won by more than a thousand votes in 2000, but in April 2003 the NPP took the seat with a majority of more than 4,000 and with some 63.9 per cent of the vote. ${ }^{1}$ Significantly, the NDC has complained about the NPP pumping money and amenities into the constituencies in time for these polls. There is more than a grain of truth to these allegations. At Wulensi, for example, one observer remarked on the miraculous appearance of street lights which led the NDC candidate to comment wryly that if MPs could be dismissed every two weeks and by-elections held, then some communities will witness faster development'. ${ }^{2}$ However, the NPP was merely playing by the rules previously laid down by the NDC which in 2004 found itself in the unenviable position of having almost no money, a presidential candidate who failed to inspire much enthusiasm and a reputation for past abuse of

1. The official turnout was, however, as low as 37.8 per cent, whereas the figure for the other by-elections was upwards of 50 per cent. It was as high as 58 per cent in Wulensi. The NDC has suffered from its inability to get its supporters to vote.

2. 'Wulensi by-election update: lies and streetlights', article from Joy Online, 4 March 2002, posted at http://www.ghanaweb.com/GhanaHomePage/NewsArchive/artikel.php?ID=33569 
office. Unexpectedly, the NPP received just128 out of 230 seats in the 2004 elections. The NDC secured 94 seats, a better result than expected, with the other opposition parties remaining as shaky as ever (PNC 4 seats, CPP 3 seats, one independent).

\section{Conclusion}

In this paper, I have tried to look beyond the mechanics of the electoral process and to examine what happens when politicians and voters interact with one another. I have argued that while large sums of money are crucial to mounting a credible bid for power in somewhere like Ghana, there is a good deal more to winning and losing than that. Money is nothing unless it can be converted into some kind of moral authority. If mishandled, the flaunting of money during campaigning may even backfire and provoke accusations of corruption and vote-buying. The NDC began life as a party which could invoke the populist imagery of the Rawlings years, while promising to bring new forms of 'development' to every community, however remote. Somewhere between 1992 and 2000, it lost its place completely. The net result was that all the positive images ended up being inverted and turned back on the party. The NDC came to be regarded as inept, uncaring and thoroughly self-serving. To make matters worse, the party turned to fratricidal squabbling over the succession to Rawlings - which has, more recently, been the undoing of KANU in Kenya and a source of some internal wrangling in both Malawi and Zambia. If Rawlings had not attempted to interfere with the NDC's internal democracy, the party might have survived the 2000 elections with a reduced majority, but the reality is that the NDC would not have achieved its past success without the Rawlings phenomenon. Rawlings has become the Frankenstinian monster which threatens to destroy the NDC in the long-run.

On the other side, the NPP has also made its own destiny, building upon the rather weak foundations which existed in 1992. Although it made relatively modest gains in 1996, it revealed the soft under-belly of the NDC in the cities as well as the growing alienation of much of southern Ghana. Its 2000 election campaign was a clever mix of appeals to areas of historic strength as well as to new bases of support in the cities and regional capitals. As the NPP came to be perceived as the only realistic alternative to the NDC, the smaller opposition parties were squeezed out of the frame. Nkrumahism may well bounce back at some time in the future, but for this to happen the inheritors of the tradition need to recover a knack for 
cementing unity, repackage their message for modern times and, of course, find some wealthy sponsors. For the moment, however, it is difficult to see where a realistic challenge to the NPP will emanate from. At present, the new government commands what looks like a winning coalition, built upon its own interpretation on the past and its blueprint for the future. It has also commandeered most of the material resources as well. Although IMF criticism of the spending record of the administration may necessitate the paring back of public expenditure in an election year, the NPP has enough in the bag to impose a stranglehold on power.

\section{References}

\section{Primary Sources}

Republic of Ghana (2001), Ghana Gazette, No. 1, 5 January; No. 2, 12 January.

Crusading Guide (Accra)

Daily Despatch (Accra)

Daily Graphic (Accra)

Free Press (Accra)

Joy Online (Accra)

\section{Secondary Sources}

Ayee, J.R.A. (ed.) (undated), The 1996 General Elections and Democratic Consolidation in Ghana. Accra: Gold-Type.

Ayee, J.R.A. (ed.) (2001), Deepening Democracy in Ghana: Politics of the 2000 Elections - Volume Two: Constituency Studies. Accra: Freedom Publications.

Boafo-Arthur, K. (undated), 'Party organisation, finance and the democratic process: the case of the opposition parties', in Ayee, J.R.A. (ed.) The 1996 General Elections and Democratic Consolidation in Ghana. Accra: Gold-Type, pp. 71-92.

Boone, C. (1992), Merchant Capital and the Roots of State Power in Senegal, 1930 1985. Cambridge: Cambridge University Press.

Geschiere, P. (1997), The Modernity of Witchcraft: Politics and the Occult in PostColonial Africa. Charlottesville \& London: University Press of Virginia.

Haugerud, A. (1995), The Culture of Politics in Modern Kenya. Cambridge: Cambridge University Press.

Hodges, T. (2001), Angola: From Afro-Stalinism to Petro-Diamond Capitalism. London, Norway, Oxford, Bloomington \& Indianapolis: IAI, Fridjtof Nansen Institute, James Currey \& Indiana University Press. 
Lonsdale, J. (1992), 'The moral economy of Mau Mau', in Berman, B. and J. Lonsdale, (eds) Unhappy Valley: Conflict in Kenya and Africa, Books One and Two. London: James Currey, pp. 315-504.

Messone, N.N. and J.-G. Gros (1998), 'The irony of wealth: democratization in Gabon', in Gros J.-G. (ed.), Democratization in Late Twentieth-Century Africa: Coping With Uncertainty. Westport \& London: Greenwood Press, pp. 129-146.

Nugent, P. (1995), Big Men, Small Boys and Politics: Power, Ideology and the Burden of History, 1982-1994. London and New York: Frances Pinter.

Nugent, P. (1999), 'Living in the past: urban, rural and ethnic themes in the 1992 and 1996 elections', Journal of Modern African Studies 37: 2, pp. 287-319.

Nugent, P. (2001a), 'Ethnicity as an explanatory factor in the Ghana 2000 elections', Issue XXIX: 1/2, pp. 2-7.

Nugent, P. (2001b), 'The things that money can buy: chieftaincy, the media and the 1996 elections in Hohoe-North constituency'. Ghana Studies 4, pp. 85-106.

Nugent, P. (2001c), 'Winners, losers and also rans: money, moral authority and voting patterns in the Ghana 2000 election', African Affairs 100, pp. 405-428.

Nugent, P. (2004), Africa since Independence: A Comparative History. London and New York: Palgrave.

Schumaker, E.J. (1975), Politics, Bureaucracy and Rural Development in Senegal. Berkeley, Los Angeles and London: University of California Press.

Smith, D.A. (2002), 'Consolidating democracy? The structural underpinnings of Ghana's 2000 elections', Journal of Modern African Studies 40: 4, pp. 621-650.

Tangri, R. (1999), The Politics of Patronage in Ghana: Parastatals, Privatization and Private Enterprise in Africa. Oxford, Kampala and Trenton: James Currey, Fountain Publishers \& Africa World Press.

Throup, D. (1987), 'The construction and destruction of the Kenyatta state', in Schatzberg, M.G. (ed.) The Political Economy of Kenya. New York, Westport \& London: Praeger, pp. 33-74.

Van de Walle, N. (2001), African Economies and the Politics of Permanent Crisis, 19791999. Cambridge: Cambridge University Press.

Vengroff, R. and M. Magala, (2001), 'Democratic reform, transition and consolidation: evidence from Senegal's 2000 presidential election', Journal of Modern African Studies 39: 1, pp. 129-162.

Villalón, L. (1995), Islamic Society and State Power in Senegal: Disciples and Citizens in Fatick. Cambridge: Cambridge University Press.

Widner, J.A. (1992), The Rise of a Party-State in Kenya: From "Harambee!" to "Nyayo", Berkeley, Los Angeles and Oxford: University of California Press. 


\title{
Conclusion \\ The Research Agenda Ahead
}

\author{
Gero Erdmann, Matthias Basedau, Andreas Mehler
}

\section{Introduction}

As mentioned in the introduction and pointed out in most of the contributions in this book, research on Africa's political parties and party systems is still in its infancy. Thus, sweeping hypotheses prevail in party research, but since there is little empirical evidence many open questions remain. This applies, albeit to a lesser degree, to studies on electoral issues as well. The contributions in this volume have addressed only a small number of issues. In a few cases they have even opened up new fields of research (Andreas Mehler and Lisa Laakso) or applied old questions to the African context for the first time (Vicky Randall).

Other contributions raise a number of research topics and point to further lines of research. Peter Burnell reminds us to discuss the relevance of our research on political parties in Africa. For example, questions that currently preoccupy researchers studying political parties in Europe, for example 'party decline' (regardless of whether this is true or not) or the 'age of catch-allism?' (Gunther and Ramón-Montero 2002; Puhle 2002), may simply be inappropriate for the African context. Here we are confronted with problems of democratisation, with party formation and with party organisation in non-industrialised societies that pose different questions and perhaps even different research strategies. Hence we still need to find out whether our concepts are adequate for organising our observations.

As Gero Erdmann argued in his contribution on the problems of 'party research' in Africa, we can apply the established concepts of the art, despite the obvious western European bias, but we need to adapt them to a different societal and historical context. And of course, our interest in political parties will differ. In one study parties will be viewed as the explanandum (dependent variable); for instance, if we want to understand their structures, ideologies, and behaviour etc. in order to explain why they are different from parties in other societal contexts. In other studies we need to view parties as the explanans (independent variable), if we want to understand 
the pattern of a particular party system or its contribution to the process of democratisation or consolidation of democracy.

The following is an outline of some ideas for a future research agen$\mathrm{da}$ linked to issues raised in the contributions to this book and organised along the lines of the following topics: political parties, party systems, and voters and elections.

\section{Political parties}

A fundamental problem of political parties in Africa which has remained largely untouched in this volume is the question of the nature of organisation. Basic information about the organisational structure of political parties is still sketchy. Although as E. Gyimah-Boadi and Gero Erdmann point out here about weak party structures, we still lack basic empirical evidence. We lack information about the size of the organisations, the number of members and branches, about the type of bureaucratic structure, what the parties are doing between the elections, are they in operation at all or are they dormant? How members relate to their respective parties, are they active or rather passive etc.?

Why is the question about the type or nature of organisation so important? The importance lies in the dual role parties have to play, and, in many cases, actually do play but in different ways. As intermediary institutions between state and society parties need to have linkages to society as well as to the state. In a 'bottom-up' perspective parties are supposed to organise, channel, and express societal group interests. From a 'top-down' perspective they should emanate political ideas and programmes which give the citizenry a direction, and they should enable authoritative decision making for the polity. ${ }^{1}$ By doing this they provide a legitimising function for the democratic regime. The effectiveness of how this dual role towards society and state is performed depends on the mode or nature of the party organisation. Hence, we need to establish the extent of variance between the parties in Africa or ask more specifically, is there a rather uniform type of party, perhaps even a type of average 'African party' or are there several distinct types of parties at the same time? For example, is there any difference between former 'state parties' and recently emerged 'democratising' parties? Is there a difference in the mode of organisation between parties in

1. The different perspectives are taken from van Biezen's approach (2003: 5), although our content is different; one could also cite the four or five core functions of the functionalist approach, see Erdmann in this volume. 
government and in opposition? Are there different ways how parties relate to civil society or more generally to societal groups?

Again we might be caught in a dilemma. We already know that it is difficult to apply the established concepts of western European biased party research to different societal contexts. At the same time we will have difficulties constructing new types of parties while we have limited empirical knowledge. On the other hand, data collection without conceptual guidance is difficult and tends to become meaningless. Hence, we have to rely on established types and concepts, at least heuristically, and adapt and refine them with contextual sensitivity. This is not a problem confined to party research in Africa but, as Ingrid van Biezen (2003: 6) has pointed out, to newly emerging democracies in eastern and southern Europe in general, not to mention Latin America and Asia. Hence, Gunther and Diamond's party typology as suggested by Erdmann (in this volume) applied to African parties can provide only a start for further conceptual considerations and empirical research on the mode of organisation. Future studies need to tackle this issue on three different levels: the national, the district, and the local. Or, to put it in proper party research terms, to study political parties at the headquarters, in parliament, and on the ground in the districts and villages (Mair 1999). Additionally, we need to know more about how party headquarters relate to their lower level units. Obviously, we need to know more about internal party democracy. How, for instance, are party functionaries and party leaders elected? Party constitutions, which usually all registered parties are required to have, prescribe democratic elections for the party's leadership. But to what extent are these elections held, and are they free and fair? There is little doubt that the internal mode of party organisation has an impact on how a party relates to society and to government. To note that party structures are weak is certainly not sufficient. We need to know more precisely in which way they are weak (internally), and in relation to what (externally e.g. state and/or society).

One crucial aspect of party organisation, which is entirely missing from party research in Africa but regularly mentioned as a disrupting 'force', is the phenomenon of factionalism. To our knowledge there is no article or book that addresses this problem in an African context. More generally, the problem is frequently mentioned in studies of political parties, but systematic research on factionalism is rare. ${ }^{1} \mathrm{~A}$ faction-ridden party is probably not in a position to formulate a coherent policy or programme that appeals to

1. There are only three German publications dedicated to this issue Basedau, Erdmann and Schmidt in Köllner et al. 2006). 
the electorate. On the other hand, different factions within a party might articulate interests of different social issues, and by doing that become attractive for a wide variety of social groups that turn the organisation into a truly broad 'people's party, (Volkspartei). In the end, the problem might not be the occurrence of factions per se but the kind of factionalism (weak, moderate, strong) that is crucial for the performance of the party.

This also raises questions about the nature of the factions. Are they interest based or personalistic? And it also raises questions about the way parties organise. Is it informal or formal or bureaucratic or more loosely knit? Dennis Beller and Frank Belloni's (1978) distinction between a) cliques and tendencies, b) personal, clientele groups, and c) formally organised, institutionalised factions appears to be a useful start for further analysis (see Köllner and Basedau 2005). Then there is the question of to what extent factionalism is tolerated and even formally accepted as a means to accommodate different social and political interests or whether it is suppressed and proscribed. Factionalism is a field of research on its own.

Questions with regard to the mode of organisation are closely linked with Vicky Randall's problem of representation which concerns the linkage of political parties to society. From her survey of the literature, Randall finds that these linkages are usually shaky. There seems to be a degree of 'descriptive representation' for ethnic groups and, increasingly, for women, but a 'substantive' representation of social groups and civil society organisations is scarce. However, some of the parties seem to maintain closer links to society by representing ethnic groups, a kind of substantive or interest representation, through clientelistic relationships.

Related to the basic issue of representation is the relationship between the party headquarters and the parliamentary party. One unexplored issue is the locus of control: Is it the MPs or the party leadership proper? We know of no research on this question. It may seem strange, but some of the minority leaders with whom we spoke confessed that they had never thought about this relationship. Perhaps it is not an important issue. But if this is the case, then that itself tells us something about the character of the parties as well.

While Randall addresses clientelism as a relationship between party and society, clientelism can also be addressed as an internal relationship of political parties. As indicated by Erdmann in this volume, informality seems to be a predominant feature of party politics, and clientelism figures prominently as a supplement for bureaucratic structures. Because hardly any research on the organisation of political parties is available, this is still 
a hypothesis derived from the general assumption that clientelism is a constituent element of politics in Africa. However, if the concept of clientelism is taken seriously as a dyadic personal relationship between a patron and a client, it seems doubtful that a network of clientelist relationships exists within a political party and that it can maintain a countrywide structure. There are some indications that the relevance of clientelist relationships has in general been overestimated (see below) with the result that it tends to become a vacuous catch-all concept.

Patronage is another informal instrument to provide a linkage to society for the mobilisation of members and voters (see among many others e.g. Gyimah-Boadi in this volume). Although both concepts, clientelism and patronage, are juxtaposed and concurrently used, it is unclear whether they refer to the same or distinct observations. The vast literature that makes use of both concepts is very unclear about the distinction. In our understanding, the distinction between them can be meaningful if we define clientelism, closely related to the anthropological meaning of the notion, as a dyadic, face-to-face relationship between two socially unequal individuals that implies the distribution of favours to individuals. In contrast, patronage is then defined as the politically motivated distribution of favours to entire groups. The distinction between clientelism and patronage is finally the difference between 'individual' and 'collective' benefits or goods (Erdmann and Engel 2006: 18). Both, of course, can be interlinked with each other.

Both clientelism and patronage are usually linked with neopatrimonialism which has become a prominent feature for describing institutional settings in Africa. If the assumption of weak party organisations is true, and if clientelism plays a crucial role in the internal party organisation, then a neopatrimonial structure seems to be obvious here as well. However, and apart from the problem that neopatrimonialism tends to have developed a catch-all character, the question is are the party structures neopatrimonial or rather patrimonial? Neopatrimonialism conceptually requires a separate legal-rational bureaucratic structure if it is to be associated with patrimonial relationships (Erdmann and Engel 2006: 17-19). But many parties seem to have hardly any formal bureaucratic structure to speak of, and their frequent dependency on one or a few financial patrons suggests a high degree of patrimonialism. Thus, in most cases it might be more sensible to speak of patrimonial parties.

Even with this conceptual clarification of neopatrimonialism, we are confronted with a fundamental conceptual and methodological challenge of how we best can analyse social phenomena that are not easily 'visible' 
('invisibility' is a main characteristic of informal politics). Is there anything methodologically beyond the 'thick description' of the anthropologist so that we can bring clientelism, patronage, and neopatrimonialism into a conceptually comparative perspective? Even if we are restricted to 'thick description', we do not even have such descriptions that attempt to disentangle the patrimonial and legal-rational bureaucratic components and to explain how they function. Thus, we need, above all, a number of casestudies on the mode of organisation of various parties in different countries, in order to find solutions for the numerous questions raised above. The studies of the informal internal and external relationships of parties should be based, at least partly, on an anthropological approach. Since we do not have conceptual and instrumental clarity as regards the research on informal relationships and politics there seems to be no alternative to the case study approach of more or less 'thick descriptions' as a beginning.

Another important aspect of party organisation is funding. Although a number of countries maintain a public system of party funding (Austin and Tjernström 2003), ${ }^{1}$ most parties cannot live on membership dues but have to rely on private donations from 'well wishers', usually rich businessmen (this is especially true during election campaigns). Some parties are funded by a single 'big man', others by a group of 'big men' (usually businessmen). Even major political parties receive a great deal of money from such 'private' sources which, in many cases, are neither made public nor accounted for. In several countries US $\$ 20,000$ has been considered necessary to run an election campaign for a seat in parliament. But funding elections is only one problem for political parties. Another is the costs incurred in running a bureaucratic organisation (offices, staff, vehicles and communication etc), on the national level as well as in the regions and at district level throughout the year. Only the larger parties are usually in a position to maintain permanent regional or district offices and perhaps staff during the time between the elections. What, then, is the effect of this more or less discreet type of funding by a few rich 'well-wishers'? How does this influence the organisation of the party? How does it affect political participation and the loyalty of members? What is the impact on the quality of party politics?

Paul Nugent's contribution in this volume reminds us that money does not directly translate into votes and, we may add, into influence. It has to

1. In 12 countries out of 22 African cases surveyed by IDEA (Austin and Tjernström 2003) political parties receive public funding (Benin, Burkina Faso, Cape Verde, Madagascar, Malawi, Mali, Namibia, Niger, Sao Tomé, Seychelles, South Africa and Tanzania). 
come along with a message or morale to have an impact. Money transformed into politics can have different meanings. Indeed, we should keep in mind that many of the new political associations and political parties were fuelled by money and in-kind contributions of small and big business men and women during the transition period - money which helped to bring about these parties. This money was then associated with the promise of 'freedom'. The other side of this is the link to corruption. How far is this type of party funding directly and intentionally linked to corruption in the parties themselves as well as corrupting the 'principles' and politics of political parties? In other words, is there a systematic link between this kind of party funding and large scale corruption schemes - at least, if the party has made it into government? Here again, to discover the secrets of party funding and finance we have, for a start, only the possibility of qualitative research methods.

To understand the specific characteristic of political parties in Africa we might also need to look at the international dimension as Peter Burnell has pointed out in his contribution. That is, the type of support parties receive from abroad. There are various ways of funding political parties from abroad. One major channel for funding is linked to the so-called multiparty approach which is used by most donors and which implies that funds are usually made available, not for all, but for the relevant parties i.e. those that are represented in parliament, for example. Another channel of funding parties is through party-to-party aid, perhaps arranged through political foundations. In addition to this there is also some (informal) money channelled to political parties from the diasporas abroad which is difficult to assess. However, the amount of 'official' foreign aid to political parties in Africa, although we have no accurate data, is very likely much smaller than the money generated locally by the business community. At the same time party aid from abroad does not only come with money but trips with specific advice and ideas about political parties and party politics - ideas which are based on specific party models derived from industrialised countries. The effect this kind of party aid has is of course of interest, although it is difficult to analyse. ${ }^{1}$

All these organisational issues are closely linked with the problem of the institutionalisation of political parties. And the latter is in turn relevant for the problem of the institutionalisation of the party system, hence, for the development and consolidation of democracy, or more generally, for

1. For the problems of party aid see Kumar 2004; Carothers 2004; Burnell 2005; Erdmann 2005. 
the quality of the political regime. However, before we can come up with any meaningful comparative quantitative statements about this we have to start, as frequently mentioned above, with qualitatively orienated case studies, carefully designed approaches which are framed by the concepts of party research, and which might need some specific refinement and modification in order to make them useful for party research in Africa.

\section{Party systems}

Most work on African party systems has left the question about the most suitable party system typology for Africa unanswered. To find appropriate classification systems is not just a trend of political scientists to play around with various types as an end in itself, but a necessary tool to organise our research, particularly if we want to treat the party systems as an explanans for the quality of the political regime or its chances of consolidating democracy. In a recent article, Matthjis Bogaards (2003) has convincingly suggested that Sartori's (1976) seminal method of counting relevant parties together with his typology of party systems is, particularly in the case of Africa, still the best approach. Using this approach requires that we examine if Sartori's typology is appropriate for the African context; and then how the features of the particular types relate to the quality of the regime can be discussed. One problematic point with Sartori's typology might be that it was born out of the great ideological confrontation of the 20th century. It presupposes the concept of polarisation, which may not be at all relevant for party systems in Africa. It is possible that Sartori's typology only requires a small modification which places more emphasis on the mode of behaviour and relationship between the parties than on ideological distance.

As mentioned in the introduction, it is hardly sufficient to identify a kind of 'average' political party system for more than 40 different party systems in Africa. What is the meaning of such an average system for all these countries? Nobody would try to apply this kind of approach to party systems in Europe. The reason is quite simple. It makes the different party systems, tentatively, all the same. Consequently, it becomes difficult to analyse whether different party systems have an impact on the chances of consolidation, the capability of governments or the quality of governance.

This takes us to the debate about the role of the party system for the quality of government, the political regime, and the consolidation of democracy. Theoretically, the particular relevance of political parties seems to be clear, yet there are empirical doubts whether the role of the party system 
has been overestimated. This is something that can be seen to go beyond research on party systems in Africa alone. It is of more general relevance because it concerns the consolidation of the various partial regimes of which the party system is only one; and it is also important for our understanding of how democracy is consolidated. Perhaps the consolidation of the party system is not very relevant for the quality of democracy because it can partly be replaced, for example, by a lively civil society, or by a strict adherence to the rule of law by the government and the administration (although the latter is not to be expected to be of major relevance in Africa).

If we turn our attention to comparative studies such as Matthias Basedau's contribution, we are confronted with a number of conceptual as well as methodological problems that need further attention. Again, some of these go well beyond the African context. First, we lack information, a problem which is particularly acute for Africa. Second, we require conceptual clarification. We need to have a common understanding about what we mean by such terms as 'institutionalisation' or 'polarisation' because without it we will face difficulties in collecting data for comparative studies. A more general problem is whether a particular type of 'defective' party system is the effect of an authoritarian regime or is its cause.

Finally, there is a need to look at parties as a dependent variable (explanandum). Although the classic work of Maurice Duverger (1959) on the link between electoral systems and the fragmentation of the party systems still enjoys prominence, the debate has moved on (Lijphart 1994; Nohlen 1996, 2000) particularly because it does not seem that African party systems obey Duverger's 'laws' at all. The emergence of a special type of party system clearly depends on the social and political context of a given country. The classic cleavage theory of Martin S. Lipset's and Stein Rokkan's (1967) seminal work may serve as a starting point, although it will clearly have to be adapted to take into account the African context (Erdmann and Weiland 2001; see also Vicky Randall, this volume, on the issue). Most of the cleavages identified by Lipset and Rokkan for western Europe - urban versus rural, religion versus state, labour versus capital and centre versus periphery - can be identified in Africa as well. In Africa, however, these cleavages are weakly developed and thus contribute little to the formation of political parties. Instead, ethnicity seems to be the predominant cleavage for party formation. However, as pointed out in Erdmann's contribution, we know very little about how ethnicity in its various facets structures party formation and affects the party systems. In order to obtain a better understanding of this relationship we require historical analyses that take 
into account the ethnic contingencies of each party system, their number and size and how the parties relate socially and politically to each other.

Basedau's findings in this volume pose a cardinal question. First of all, he did not find a strong correlation between party system and regime performance apart from 'polarisation' (and a little institutionalisation). One reason for this failure is, as he points out, the lack of proper data. However, another conclusion which might be possible and worth further investigation is that it is not the party system itself but political polarisation in the society which gives rise to the polarisation of the political parties. The specific evolution of the party system - particularly the numbers of parties and, perhaps, although to a lesser degree, the degree of institutionalisation - might be of little relevance for the problems that make democracy difficult to sustain. The party system would thus be only a kind of 'dummy', a surrogate for deeper and fundamental conflicts or 'polarisation' that 'explain' different regime performances.

At the same time we have to be clear about the level of analysis - are we concerned with the single party or the party system? The question 'which type of party system' is different from the question 'which type of party' is more supportive for the consolidation of democracy. This essential distinction is not always clearly observed in more recent studies of African parties and party systems but often blurred. ${ }^{1}$ However, this kind of conflation is also a problem of party research in general as has been pointed out by Randall and Svåsand (2002) in relation to the question of institutionalisation of parties or party systems.

Here again, future research on political party systems has to be concerned with conceptual clarity and with questions of conceptual innovations for the African context. Beyond the methodological issues we are plagued by the paucity of information which came out most clearly from Randall's and Basedau's contributions. Hence, one of the foremost issues is the provision of basic data which is extremely thin for any meaningful comparative research design.

\section{Voters and elections}

Elections are the source of legitimacy for many political regimes; they are one way, but a fundamental one, of participating in a democratic regime; and they are at the heart of liberal democracy. Thus the organisation of elections is a crucial issue for both those who rule and those who vote.

1. See for example: Mozaffar et al. 2003; van de Walle 2003. 
There is a controversial debate about the significance of the electoral system, in which some scholars state that the electoral system is the 'most fundamental element of representative democracy' (Lijphart 1994:1; Sartori 1994: ix). In addition and according to Sartori (ibid.), electoral systems are the 'most manipulative instrument of politics'. Although this should be seen as an exaggeration - as social cleavages, power relations and political culture etc. play a crucial role as well or even a more important one - it is undisputed that electoral systems influence a) voting behaviour, b) elections results, c) political representation, and d) the party system. They also determine political preferences and the transfer of power. The relevance of the electoral system is dependent on the historical context, and monocausal explanations are usually not very helpful (Nohlen 2000: 58).

Since the democratic transitions of the early 1990s the discussion about the suitability of electoral systems to the African context in general and to a given country in particular, has come to life again. The debate about electoral systems is not merely of academic relevance, but, more importantly it is a practical political issue which is related to hotly debated questions of reform of electoral systems and of reform politics. Which electoral system is in place has become a hotly disputed concern for ruling and opposition parties alike. A reform of the electoral system can increase the opposition's chances of winning the election, it might also help the incumbent party maintain its hold on power (e.g. if they go from an absolute to relative majority rule). Although African electoral systems comprise a variety of different systems - they range from first-past-the-post to mixed member proportional - the debate about the pros and cons of electoral systems is usually based on the dichotomy of majority versus plurality systems. This controversy of 'conventional wisdoms' is not only too simplistic and based on a normative approach, but, as Dieter Nohlen (1996: 23; 2000: 142-9) has observed, 'there are more assumptions than truly systematic findings about the effects of electoral systems'. Both Matthjis Bogaards' and Christof Hartmann's contributions help to overcome the normative simplicity of the debate and to differentiate the issues involved.

In the face of the predominant ethnic cleavage in African political systems Matthijs Bogaards argues that the old controversy about proportional or majority system seems to be rather irrelevant. Instead, he suggests that electoral systems should be chosen on the basis of two different perspectives: an electoral system should either promote the aggregation of socio-cultural divisions (reconcile ethnic differences) or block the party organisation of 
sub-national cleavages. One solution could be 'constituency pooling', although this has never been tried in Africa.

However, from Hartmann's Politics of Electoral Reform in Africa we learn that it is difficult to come to grips with electoral reforms. He indicates that electoral reform is a thorny business in Africa. Hence reforms are rather scarce. This is not surprising, since electoral reform is not only a technical issue but implies questions of power. Those who are propelled to power through an existing system will try to maintain it, while others without power will demand reform. Political parties usually make decisions according to their perceived interests and not on principle. The result is that no major reforms have taken place since the current electoral systems were established - often through the former colonial power. A related reason for the lack of reform is that too little is known about the possible consequences of a change and hence the entrenched interests of politicians mean that they are resistant to change.

Nevertheless, despite these unfavourable circumstances there have been some electoral reforms in Africa. As Hartmann points out, where there has been successful reform it has usually been incremental and 'path-dependent change', that is, the reforms continue to follow the institutional path of their former colonial rulers. What is notable is that the trend of these reforms has a familiar pattern in that they are essentially a move from a plurality to a proportional system, in the African cases, however, only towards a combined system.

As stated above, there are many electoral studies available but, with the exception of Reynold's, hardly any can be called comparative. We rarely have 'hard' information about what makes people vote for one party or another. There is a lot of speculation about the people's motives but despite the plausibility of these explanations a systematic psephology is missing. Just as we know next to nothing about voting behaviour, we know next to nothing about what makes people transfer their vote from one party to another. For instance, although it is widely presumed that ethnicity plays a crucial role in shaping voting behaviour this has been recently questioned (Nugent 2001) because it is too simplistic. ${ }^{1}$ Ethnicity may be a predominant motive but not the only one.

Like academics, local people, too, contradict each other. Some people say voting is 'tribal', while others object, and point their fingers to the be-

1. To be clear here, often the crucial role of ethnicity is rather assumed implicitly than explicitly when academics write about ethnic conflict, politics or the character of parties; see Glickman 1995 and Ottaway 1999. 
haviour of rural people only. But is this so? We know, for instance, from sociological studies that moving to an urban area does not automatically imply losing all rural traits and becoming an urbanite without any ethnic identity. Ethnicity can 'survive' in urban areas and even become more salient. If we examine particular regions wherein election after election a particular party receives the vast majority of votes, it seems irrefutable that in these regions voting is ethnically based. However, there are always some groups that confound this generalisation. And moreover, there are cases in which the majority moves from one party to the other. Simple ethnic arithmetic can hardly explain it and hence there must be other 'motives' at work.

To work out the nature of voting behaviour, two different or even combined approaches seem to be necessary. First, we need detailed analysis of the ethnic composition of constituencies which shift from one party to another over time (this would require surveys on a collective level). Second, we need surveys on the individual level to discover the motives for voting (e.g. opinion polls). One potential explanation for a shift in party preference is that it needs only a small number of voters with no specific ethnic affiliation to cause the shift.

Closely related to the question about ethnicity is that of clientelism, which has taken on a prominent role in explaining not only political but voting behaviour. Contrary to the 'conventional wisdom', Staffan Lindberg and Minion K.C. Morrison's (2004) survey of Ghanaian voters suggests that clientelism is not a major factor in determining individual voting behaviour. Based on what we learned from our discussions with political party officials and campaigners in Botswana, Ghana, Malawi, Tanzania, and Zambia about the way election campaigns are organised and conducted, we tend to support Lindberg and Morrison's findings. Again, we need more such studies, not only to falsify the 'conventional wisdom', but to positively to find out what makes the voters 'tick'. For that we need qualitative or anthropological approaches in addition to carefully designed quantitative methods.

As regards the problem of vote buying which comes along with clientelism, patronage and the 'big men' syndrome, we also need more of Paul Nugent's paradigmatic case studies. Different societal contexts might entail different meanings and different outcomes of vote buying. In some circumstances it might have no impact at all.

Finally, there remains the unexplored role of violence related to political parties. Fundamental here again is the causation problem: Is electoral 
violence an expression of party politics or is violence ingrained in the specific social fabric and hence violent relations between party members an effect of the latter? This problem, most likely, cannot be solved. However, Andreas Mehler attributes the frequency of electoral violence to a number of factors, but most importantly to the state's monopoly on the use of force, to the legitimacy and efficiency of the electoral process, as well as the organisational capacities of political parties. As all these 'capacities' are not well developed in Africa, the frequency of violence cannot really be seen as surprising. Next to this institutional context of violence Lisa Laakso identifies another underlying cause of electoral violence - the economic situation which presents the opportunity to hire unemployed youth as the main perpetrators of violence. In addition, her analysis makes it clear that it is not ethnicity per se that is a source of violence and therefore an unavoidable outcome of multiethnic party competition, but, as illustrated by the case of Kenya, 'ethnic cleansing' which was so prominent during and after the 1992 and 1996 elections but not during and after the 2002 elections. However, it is evident that these are contributing factors to the occurrence of violence; they provide the structural framework for the high frequency. At the same time, we know that poverty and weak state institutions are almost ubiquitous in Africa - but violence does not occur everywhere in the same way and with the same intensity. We need to inquire into the specific circumstances in which violence flares up; there are probably different cultures of 'legitimate' violence. Future studies on electoral violence might benefit from results of other violence related research fields.

Looking at the relationship between political parties and violence one specific topic of research comes to light which is not dealt with in this volume: political parties which are based on or linked to liberation movements that had to fight an armed liberation struggle. The question is whether the violence of the liberation had a lasting impact on the structure and behaviour of these political parties. One obvious assumption is that the military organisation required by the liberation war is difficult to transform into a civil and democratic organisation. One consequence might be a lasting authoritarianism. Since all the victorious 'liberation parties' have become dominant parties in their respective countries a lasting democratisation might be difficult to achieve - Angola, Eritrea, Mozambique and Zimbabwe are cases in point, while South Africa and Namibia are quite positive examples. One basic question for future research should be, if it is the specific heritage of the party organisation or rather the more general societal experience of violence that makes democratisation more difficult. 
One other research topic that is absent from this volume is that of local government elections. These elections have become very important with the push for decentralisation in many African countries. Decentralisation has been pushed by both opposition parties as well as by the international donor community, usually hesitantly followed and implemented by governing parties. Because of the near total neglect of local government elections, we have very little hard information about the 'appropriation' of democracy on the local level, which is supposed to play an important role in the acculturation of the 'concept' of democracy. The interesting question would be how 'democratic' elections and politics in urban and rural constituencies are locally 'appropriated' and how they are intertwined with national politics.

As a research issue, the contributions in this volume have only set out some basics for further research. A number of the issues raised are clearly 'big issues' - touching on our conceptualisation of African politics - such as clientelism, patronage, and neopatrimonialism, and the like. It might appear to be naive to bring these fundamental concepts into the research on political parties, but as demonstrated by Lindberg and Morrison's abovementioned study, we have to tackle and challenge these 'big issues' conceptually and empirically. In the end, one should not forget that party research as a separate academic field of research lacks an elaborated theoretical framework - it is 'under-theorised' or theoretically underdeveloped (cf. Beyme 2000: 9, 14).

\section{References}

Austin, R. and M. Tjernström (eds) (2003), Funding of Political Parties and Election Campaigns. International Institute for Democracy and Electoral Assistance (IDEA), Handbook Series (http://www.idea.int/publications/Funding_parties/ upload/full.pdf, access 02/16/2005).

Beller, D.C. and F.P. Belloni (1978), 'Party and Faction: Modes of Political Competition’, in Beller, D.C. and F.P. Belloni (eds) Faction Politics: Political Parties and Factionalism in Comparative Perspective. Oxford: ABC-Clio, pp. $417-450$

Beyme, K. v. (2000), Parteien im Wandel. Wiesbaden: Westdeutscher Verlag.

Bogaards, M. (2003), 'Counting Parties and Identifying (Dominant) Party Systems in Africa', European Journal of Political Research 43, pp. 173-197.

Burnell, P. (2005), Globalising Party-Based Democracy: Political parties, globalisation, and international democracy assistance. Working Paper Series, Centre for the Study of Globalisation and Regionalisaion, University of Warwick.

Carothers, T. (2004), Political Party Aid- Paper prepared for the Swedish International Development Agency. Washington: Carnegie Endowment. 
Duverger, M. (1959), Political Parties: Their Organization and Activity in the Modern State. New York: Wiley.

Erdmann, G. (2005), Hesitant Bedfellows: The German Stiftungen and Party Aid in Africa. An Attempt at an Assessment. CSGR Working Paper 184/05, Centre for the Study of Globalization and Regionalisation, University of Warwick, Coventry.

Erdmann, G. and U. Engel (2006), Neopatrimonialism Revisited - Beyond a Catch-All Concept. Working Papers Global and Area Studies No. 16. Hamburg: German Institute of Global and Areas Studies.

Erdmann, G. and H. Weiland (2001), 'Gesellschaftliche Konfliktlinien, Ethnizität und Parteienformation in Afrika', in Eith, U. and G. Mielke (eds) Gesellschaftliche Konflikte und Parteiensysteme. Länder und Regionalstudien. Wiesbaden: Westdeutscher Verlag, pp. 246-262.

Glickman, H. (ed.) (1995), Ethnic Conflict and Democratization in Africa. Atlanta: African Studies Association Press.

Gunther, R. and J. Ramón-Montero (2002), 'Introduction: Reviewing and Reassessing Parties', in Gunther, R. et al. (eds), Political Parties. Old Concepts and New Challenges. Oxford: Oxford University Press, pp. 1-35.

Köllner, P., M. Basedau and G. Erdmann (eds) (2006), Innerparteiliche Machtgruppen. Faktionalismus im Internationalen Vergleich. Munich: Campus.

Köllner, P. and M. Basedau (2005), Factionalism in Political Parties: An Analytical Framework for Comparative Studies. Working Papers Global and Area Studies 12. Hamburg: German Overseas Institute.

Kumar, K. (2004), International Political Party Assistance. An Overview and Analysis. Working Paper 33. The Hague: Netherlands Institute for International Relations Clingendael.

Lijphart, A. (1994), Electoral Systems and Party Systems: A Study of Twenty-Seven Democracies, 1945-1990. New York: Oxford University Press.

Lindberg, S. and M.K.C. Morrison (2004), 'Voter Alignment in Africa: Evidence from Ghana'. Paper presented at African Studies Association 47th meeting, New Orleans.

Lipset, S.M. and S. Rokkan (eds) (1967), Party Systems and Voter Alignments: Cross National Perspectives. New York: Free Press.

Mair, S. (1999), 'Organization and Monitoring of Democratic Elections', in Kostakos, G. (ed.) Democratic Elections and the Mediterranean. Hellenic Foundation for European and Foreign Policy. Athens: ELIAMEP, pp. 73-87.

Mozaffar, S. et al. (eds) (2003), 'Electoral Institutions, Ethnopolitical Cleavages, and Party Systems in Africa's Emerging Democracies', American Political Science Review 97: 3, pp. 379-390.

Nohlen, D. (1996), Elections and Electoral Systems. New Delhi: Macmillan.

Nohlen, D. (2000), Wahlrecht und Parteiensystem. Opladen: Leske und Budrich.

Nugent, P. (2001), 'Winners, Losers and Also Rans: Money, Moral Authority and Voting Patterns in Ghana 2000 elections', African Affairs 100, pp. 405-428. 
Ottaway, M. (1999), 'Ethnic Politics in Africa: Change and Continuity', in Joseph, R. (ed.) State Conflict and Democracy in Africa. Boulder: Lynne Rienner, pp. 200-317.

Puhle, H.-J. (2002), 'Still in the Age of Catch-Allism? Volksparteien and Parteienstaat in Crisis and Realignment', in Gunther, R. et al. (eds) Political Parties. Old Concepts and New Challenges. Oxford: Oxford University Press, pp. 58-83.

Randall, V. and L. Svåsand (2002), 'Party Institutionalization in New Democracies', Party Politics 8: 1, pp. 5-29.

Sartori, G. (1976), Parties and Party Systems. A Framework for Analysis. Cambridge: Cambridge University Press.

Sartori, G. (1994), Comparative Constitutional Engineering. An Inquiry into Structures, Incentives and Outcomes. London: Macmillan.

Van Biezen, I. (2003), Political Parties in New Democracies. Party Organisation in Southern and East-Central Europe. London: Palgrave.

Van de Walle, N. (2003), 'Presidentialism and Clientelism in Africa's Emerging Party Systems', Journal of Modern African Studies 41: 2, pp. 297-321. 


\section{Index}

Acheampong, General, 21

African Christian Democrats Union, 73

Afrobarometer surveys, 26

aggregation, party-system functions, 169-70, 171-5, 177, 180-4

alternative vote (AV) electoral system, 148n, 172-3

Anckar, C., 105

Angola

elections, 112

electoral system, 160

anti-system parties, 195-6

Benin

democracy, 114

electoral system, 154, 155, 158

party system, 119-21, 124-5, 128, $131,132,134,138-41$

women's representation, 96

Bienen, Henry, 9, 35

Birch, A.H., 84-5

blocking, party-system functions, 16970, 171, 176-80

Botswana

democracy, 114

electoral system, 156, 185

party system, 119-21, 124-5, 128,

$131,138-41$

Burkina Faso

electoral system, 154, 158

party system, 116, 117n, 119-21,

$124-5,128,131,138-41$

Burundi

elections, 112

electoral system, 154n, 160, 215

Front pour la Démocratie au Burundi

(FRODEBU), 211, 215

political violence, 197-8, 206n, 209, 211, 214, 222-3

Busia, Kofi, 21

Butler, K.S., 86-7
Cameroon

Cameroon People's Democratic

Movement (CPDM), 203, 205, 216

electoral system, 154, 155, 158

ethnicity, 89, 90

party system, 116, 119-21, 124-5,

$128,131,138-41$

political cleavages, 212-13

political violence, 198, 203, 205-6,

216, 222-3

Social Democratic Front (SDF), 203, 205, 213

Union des Populations du Cameroun

(UPC), 198, 212-13

youth violence, 205

Cape Verde

democracy, 114

electoral system, 160

party system, 119-21, 124-5, 128,

130-1, 138-41

Central African Republic (CAR)

electoral system, 158

party system, 116, 119-21, 124-5,

$128,131,138-41$

political violence, 198, 206, 208, 209, 214, 222-3

Rassemblement Démocratique

Centrafricain (RDC), 200, 206

Chad

electoral system, 154, 155, 157, 158

Mouvement Patriotique du Salut (MPS), 200

party system, 116, 119-21, 124-5,

$128,131,138-41$

political violence, 198, 207-8, 209,

222-3

Union pour le Renouveau et la

Démocratie (URD), 200

civil society, and political parties, 40 , 77-8, 92-5

cleavages, political parties, 43-8, 58, 195, 212-13 
clientalism

and ethnicity, 91, 288

political parties, 50-2, 55-6, 86,

279-80

see also patronage

coalitions, ethnic, 46

Comoros

electoral system, 158, 182

party system, 116, 119-21, 124-5,

$128,131,138-41$

comparisons, political, 69

Congo (Brazzaville)

electoral system, 158

party system, 116, 119-21, 124-5, $128,131,138-41$

political violence, 199, 214, 222-3

constituency pooling, 173-4, 180-1, 188

Côte d'Ivoire

electoral system, 154, 157, 158

Front Populaire Ivoirien (FPI), 199, 201-3

Parti Democratique de Côte d'Ivoire (PDCI), 24, 178, 205, 206

party system, 116, 119-21, 124-5, $128,131,138-41$

political cleavages, 213

political violence, 199, 201-3, 204n, 205, 206, 207, 216, 222-3

Rassemblement Démocratique

Républicain (RDR), 199, 201-3

Déby, Idriss, 207-8

democracy

comparative, 106-8

concepts of, 68-9, 113

levels of, 112-15

local elections, 290

measuring, 115-31

and party systems, 105-6, 111, 131-4

social representation, 14-15

democratization, 70-1

and electoral systems, 151-5

and electoral violence, 224, 225-8

and ethnic conflict, 168-9

and violence, 213-15

\section{Democrat Union of Africa/African}

Dialogue Group, 73

Diamond, L., 53-4, 57

distribution requirements, electoral system, 174-5, 181-2, 188-9

Djibouti

electoral system, 154, 158, 184

party system, 116, 119-21, 124-5,

$128,131,138-41$

double-ballot in heterogeneous districts, 184

economic stress, electoral violence, 228-

30, 230-1, 238, 241-3

efficiency, party systems, 109

elections

and democracy, 285-6

local government, 290

and money, 255-9, 263-74, 281-2

and patronage, 28-32

research, 285-90

turn-out, 40-1, 123-4

and violence, 16-17, 68

vote buying, 17, 253-5, 288

weaknesses of, 27-8

and wealth, 17

electoral governance, 145, 146

electoral systems

alternative vote (AV), 148n, 172-3

'Best Loser', 186

choosing, 171-4, 286

Compensatory System, 150

constituency pooling, 173-4, 180-1, 188

and democratization, 151-5

distribution requirements, 174-5,

181-2, 188-9

double-ballot in heterogeneous districts, 184

and ethnicity, 15-16, 168-9, 286-7

former British colonies, 152, 153-4, 156, 163-4

former French colonies, 152, 153,

154-5, 157-9, 164 
former Portuguese colonies, 152, 154, 160

majority systems, 148, 150

Mixed Member Proportional System

(MMPS), 151

mixed systems, 150-1

multi-ethnic list voting, 184

one-party state, 176-8

path-dependency reforms, 161-5

prefabricated party system, 183-4

proportional representation (PR), 8-9,

147-9, 174, 186-7

reforms, 16, 144-7, 155-65, 287

reserved seats, 184-5

Segmented System, 150

single-transferable vote (STV), 174

transitions, 226-8

types of, 147-51

and violence, 215

electoral violence

definition, 225

and democratization, $210,224,225-8$

and economic stress, 228-30, 230-1,

238, 241-3

Kenya, 230-7

and political parties, 16-17, 68, 203,

288-9

Tanzania, 237-40

Zimbabwe, 241-6

entrepreneurs, political, 197

Equatorial Guinea

electoral system, 154n, 160

party system, 116, 119-21, 124-5,

$128,131,138-41$

Ethiopia

electoral system, 160

Ethiopian People's Revolutionary

Democratic Front (EPRDF), 117

party system, 116, 119-21, 124-5,

$128,131,138-41$

ethnic cleansing, Kenya, 232-5, 289

ethnicity

and electoral systems, 15-16, 168-9,

187-9 and political parties, 45-8, 55-7, 58, 77-9, 89-92

voting behaviour, 287-8

Europe, political parties, 43-4, 46n3, 51, 57,73

factionalism, political parties, 278-9

financing, political parties, 256-9, 281-2

formal politics, research, 48-52

former British colonies, electoral systems, 152, 153-4, 156, 163-4

former French colonies, electoral systems, $152,153,154-5,157-9,164$

former Portuguese colonies, electoral systems, 152, 154, 160

fragmentation

Moderate Fragmentation Index

(MFI), 118, 120

party systems, 109, 111, 116-21, 138, 141

Freedom House (FH) ratings, 113-15

Fru Ndi, John Ni, 203

functionalism, political parties, 66-7, 70-1, 108-9

Gabon

electoral system, 158

financing, 256

party system, 116, 119-21, 124-5, $128,131,138-41$

Gambia

electoral system, 153, 156

party system, 116, 119-21, 124-5, $128,131,138-41$

Ghana

Convention People's Party (CPP), 21, 259-60, 266, 272

31st December Women's Movement

(DWM), 98-9, 264, 271

elections, 22-3, 30-2, 254-5, 263-73

electoral system, 153, 155, 156

ethnicity, 89

National Alliance of Liberals, 21

National Democratic Congress

(NDC), 24, 26, 31-2, 79, 259-73 
New Patriotic Party (NPP), 26, 25963, 266-74

opposition parties, 26

party system, 114, 115, 117n

patronage system, 23-4, 30-2

People's National Convention (PNC), 259-73, 272

political financing, 259-73

political parties, 21-2, 259

Progress Party, 21

Provisional National Defence Council (PNDC), 23, 259

Union Government, 22, 23, 24

United Party (UP), 21

voting bahaviour, 254-5, 288

women, 99

Guinea

electoral system, 154, 158

party system, 116, 119-21, 124-5,

$128,131,138-41$

Guinea-Bissau

electoral system, 160

party system, 115

Gunther, R., 53-4, 57

Hagopian, F., 70

inclusion

political parties, 109

see also representation

informal politics

and neopatrimonialism, 74-7

research, 48-52

institutionalisation

party systems, 109-10, 111, 121-5, 139, 141, 282-3

Total Institutionalisation Score (TIS), 124

Ivory Coast see Côte d'Ivoire

Johnson-Sirleaf, Ellen, 96

Karvonen, L., 105

Kenya

corruption, 231 economic stress, 230-1

electoral system, 153, 156, 157, 175,

181

electoral violence, 225, 230-7, 246-7

ethnic cleansing, 232-5, 289

ethnic coalition, 46

Islamic Party of Kenya (IPK), 180

Kenya National Union (KANU), 24, 178, 230, 231-7, 246-7

Mungiki, 235-6

National Development Party (NDP), 235-6

National Rainbow Coalition (NARC), 230, 236

party system, 115

political benevolence, 256

political parties, 87

youth groups, 231-2

Kuenzi, M., 122-5

Lambright, G., 122-5

leaders

ethnicity, 90-2

political parties, 25

and violence, 201, 230

Lemarchand, René, 35

Lesotho

electoral system, 155, 156, 163, 164

electoral violence, $215 \mathrm{n}$

party system, 114, 115

liberation movements, violence, 289

Liberia

elections, 112

electoral system, 155, 160, 162

women, 96

Lijphart, Arend, 107

Lindberg, Staffan, 7, 127, 129, 224

Lipset, Seymour M., 43

local government elections, 290

'machine politics', 50

Madagascar

electoral system, 154, 157, 158

political violence, 201 
Malawi

electoral system, 156, 187

ethnicity, 90

party system, 115

political parties, 57

Mali

Alliance pour la Démocratie au Mali/

Alliance for Democracy (ADEMA), 24

democracy, 114, 204

electoral system, 154, 157, 158, 162, 164,184

party system, 117n, 119-21, 124-5,

128, 130-1, 132, 134, 138-41

political violence, 199, 201, 204, 214, 222-3

Mauritania

electoral system, 154, 158

party bans, 180

party system, 116, 119-21, 124-5,

$128,131,138-41$

Mauritius

democracy, 114

electoral system, 154, 156, 186

party system, 119-21, 124-5, 128, $130-1,138-41$

Mill, John Stuart, 107

minorities, representation, 185

Mmuya, Max, 39

mobilization, of voters, 40-1

Moderate Fragmentation Index (MFI), 118,120

money, and elections, 255-9, 263-74,

281-2

Mozambique

electoral system, 160

Frente de Libertação de Moçambique

(FRELIMO), 24, 96-7, 99

Organization of Mozambican Women

(OMM), 98-9

party system, 115

women, 96-7

multi-ethnic list voting, 184

multi-party systems

democratic, 113-14 non-democratic, 114-15

Namibia

democracy, 114

electoral system, 155, 160, 162, 187

party system, 119-21, 124-5, 128,

$131,138-41$

South-West Africa People's

Organization (SWAPO), 24, 97

women, 97

neopatrimonialism

and democracy, 42, 52

heritage of, 13, 28-30

and informal politics, 74-7

and political parties, 280-1

political regimes, 195-6

and violence, 216-17

Niger

electoral system, 154, 155, 158, 185

party system, 116, 117n, 119-21,

$124-5,128,131,138-41$

Nigeria

electoral system, 153, 156, 175, 182

ethnicity, 89

Independent Nigerian Electoral

Commission (INEC), 180

National Republican Convention

(NRC), 183

party system, 116, 119-21, 124-5,

$128,131,138-41,183-4$

Progressive Democratic Party (PDP), 121

Social Democratic Party (SDP), 24, 183

Nkrumah, Kwame, 21, 27, 179, 259, 261

Obote, Milton, 174, 180-1

one-party state, $176-8$

opposition parties

discrediting of, 207

functions of, 42-3

marginalisation, 118

membership of, 87

mistrust of, 7-8, 26

Ottaway, M., 89 
party systems

characteristics, 108-12

and democracy, 105-6, 111, 112-15,

$131-4$

fragmentation, 109, 111, 116-21, 138,141

functions, 169-76

institutionalisation, 109-10, 111, 121-5, 139, 141, 282-3

measuring characteristics, 115-31

non-democratic, 114-15

polarisation, 110, 125-30, 140, 141,

195

research on, 10-11, 36, 283-5

patronage

challenges to, 30-2

in elections, 28-32

Ghana, 23-4, 30-2

political parties, 42, 280

see also clientalism; neopatrimonialism

Pedersen Index, 121, 123

Pitkin, Hannah, 15, 83-4

pluralism, political parties, 117-19

polarisation

party systems, 110, 125-30, 140, 141, 195

Total Polarisation Score (TPS), 127

political parties

African typology, 12, 24-6, 52-7, 58, 71-3, 277-8

attitudes to, 41-2

bans, 179-80, 187-8

characteristics, 36-7, 67-8

cleavages, 43-8, 58, 195, 212-13

clientalism, 50-2, 55-6, 86, 279-80

ethnicity, 45-8, 55-7, 58, 77-9,

89-92

factionalism, 278-9

functions, 38-43, 57, 66-7, 70-1, 73-4, 108-9

funding, 256-9, 281-2

gender quotas, 96-7

informal relations, 48-52

leaders, 90-1 leadership, 25

mistrust of, 7-8

and neopatrimonialism, 280-1

as organisations, 11-12

particularist, 45, 55, 179-80, 187-8

and party systems, 108

patronage, 42, 280

and representation, 82-6, 279

research on, 9-12, 14, 34-6, 65-7,

277-83

social representation, 14-15, 88

terminology, 194-7

and violence, 194, 200-1, 204-6,

217-18, 222-3, 288-9

see also opposition parties; party

systems

political representation see representation polyarchy, 113

post-structuralism, 84

poverty, and electoral violence, 228-30

prefabricated party system, 183-4

proportional representation (PR), 8-9, 147-9, 174, 186-7

Quantin, Patrick, 227

Ravalomanana, Marc, 201

Rawlings, Jerry, 22, 23, 31, 260-1, 269-70, 273

regionalism, political parties, 90

religious groups, political representation, 88

representation

African political parties, 86-8

civil society, 92-5

concept of, 82-4

descriptive, 83

minorities, 185

and political parties, 84-6, 185, 279

responsive, 84

social groups, 14-15, 88

women, 96-101, 185

research

elections, 285-90 
European bias, 34-6, 58

future, $80,276-7$

informal approaches, 76

party systems, 10-11, 36, 283-5

political parties, 9-12, 14, 34-6,

$65-7,277-83$

reserved seats, electoral systems, 184-5

Reynolds, Andrew, 8-9

Rokkan, Stein, 43

Rwanda, elections, 112

Salih, Mohamed, 12

Sao Tomé

democracy, 114

electoral system, 160

party system, 119-21, 124-5, 128,

$131,138-41$

Sartori, Giovanni, 35, 46n2, 107, 109, 169,283

Senegal

electoral system, 154, 158

party system, 114, 115, 183n

political parties, 257-8

Seychelles

electoral system, 154, 156

party system, 115

Sierra Leone

electoral system, 154, 155, 156, 162, 185

party system, 116, 119-21, 124-5,

$128,131,138-41,178,179-80$

single-transferable vote (STV), 174

social groups, political representation,

$$
\text { 14-15, } 88
$$

Soglo, Rosine, 96

South Africa

African National Congress (ANC), 24, 72, 94-5, 96, 117

Congress of South African Trade Unions (COSATU), 94-5

democracy, 114

electoral system, 155, 159, 160, 162

Growth, Employment and

Redistribution Programme (GEAR), 95 party system, 119-21, 124-5, 128,

$131,138-41$

trade unions, 94-5

women, 96, 98

Women's National Coalition, 97, 99,

100

Structural Adjustment Programmes, 229, 241, 255, 260

'systemness', party system, 109

Tanzania

Chama Cha Mapinduzi (CCM), 24, $37,56,237,239-40$

civil society, 93

electoral system, 153, 156, 178, 185

electoral violence, 225, 237-40

ethnic parties, 89-90

opposition parties, 87

party system, 115

see also Zanzibar

Togo

electoral system, 158

party system, 116, 119-21, 124-5,

$128,131,138-41$

Total Institutionalisation Score (TIS), 124

Total Polarisation Score (TPS), 127

trade unions, political representation, 94-5

translation, party-system function, 169$70,172,175,177,184-7$

Tsvangirai, Morgan, 94, 242, 244

Uganda

electoral system, 153, 156, 180-1

party system, $178 \mathrm{n}$

United States, informal politics, 76

Van de Walle, N., 86-7, 91, 126

violence

causes of, 75

electoral, 16-17, 68, 203, 210

as expression of grievances, 203-4

as historical opportunity, 201-3 
liberation movements, 289

as means of domination, 204-6

monopoly of, 210-11

and neopatrimonialism, 216-17

as political means, 199-208

and political parties, 194, 200-1,

204-6, 217-18, 222-3, 288-9

provocation of, 207

and state weakness, 215-16

terminology, 197

youth groups, 205, 229, 231-2, 238, 248

vote buying, 17, 253-5, 288

voting behaviour, 40-1, 287-8

Wallerstein, Immanuel, 9

Wanjohi, N.G., 87

warlords, 196, 200

wealth, and elections, 17

women, representation of, 96-101, 185

youth groups, violence, 205, 229, 231-2,

238, 248

Zambia

civil society, 93-4

electoral system, 153, 156

Movement for Multi-Party Democracy (MMD), 24, 93, 94

party system, 116, 119-21, 124-5,

$128,131,138-41$

political parties, 41
United National Independence Party (UNIP), 24, 72

voting behaviour, 47

women, 98

Zanzibar

Afro-Shirazi Party (ASP), 237-8

Civic United Front (CUF), 239-40

economic recession, 238-9

electoral system, 186

electoral violence, 225, 237-40, 248

youth groups, 238

Zanzibar Nationalist Party (ZNP), 237-9

see also Tanzania

Zimbabwe

economic crisis, 241-3

electoral system, 185, 186n

electoral violence, 225, 241-6, 247-9

ethnicity, 89

Movement for Democratic Change

(MDC), 93, 94, 242-6

party system, 116, 119-21, 124-5,

$128,131,138-41$

war veterans, 243-4

women, 98

Zimbabwe African National UnionPatriotic Front (ZANU-PF), 24, 241, 243-6

Zimbabwe People's Union (ZAPU), 241 